\title{
The Course and Canon of Left Nationalism in English Canada, 1968-1979
}

\author{
by \\ Michael Cesare Chiarello
}

A thesis submitted to the Faculty of Graduate and Postdoctoral Affairs in partial fulfillment of the requirements for the degree of

Doctor of Philosophy

in

History with Specialization in Political Economy

Carleton University

Ottawa, Ontario

(C) 2020, Michael Cesare Chiarello 


\section{Abstract}

This dissertation is an inquiry into the political and intellectual currents of English Canadian left nationalism from the late 1960s through the 1970s. It investigates the reasons why left nationalism emerged as a major force in English Canadian left politics and explores the evolution of a neo-Marxist critique of both Canadian capitalism and Canada's relationship with the United States. Left nationalism represented a distinctive perspective and political agenda. Its vision was of a Canada divorced from the American-led capitalist world system. English Canadian left nationalism had a political manifestation in the Waffle movement and an intellectual manifestation in the New Canadian Political Economy. The dissertation demonstrates that the left nationalist interpretation of CanadianAmerican relations was not rooted in anti-Americanism, but in a radical politics of democratic socialism and anti-imperialism. Left nationalism was primarily the product of neo-Marxist thought, rather than a reaction to problems in American politics, society, and foreign policy. English Canadian left nationalists were disruptors who, unlike their New Nationalist contemporaries, did not advance a program of capitalist or social democratic reform. The left nationalists were determined to replace capitalism with democratic socialism; without socialism, there could be no Canadian independence. Left nationalists sought to end Canada's colonial status in the declining American empire, viewed the preservation of Canada's resources as imperative to the country's long-term prosperity, and advanced neo-Marxism in the academy and in the universities. The dissertation 
interrogates internal debates within the New Democratic Party over how to respond to the problem of American dependency; the rise and fall of the Waffle movement; the left nationalist response to crises in Canadian-American relations during the late 1960s and early 1970s; and the establishment of the New Canadian Political Economy, left nationalism's most enduring legacy. 


\section{Acknowledgments}

Writing a dissertation is a long, complicated, at times frustrating, but ultimately rewarding experience. I spent over 7 years as a graduate student at the Department of History at Carleton University and I will be eternally grateful for all the help and support I received. Special thanks goes out to Joan White, the Department's graduate administrator, who has been crucial in guiding me through all the intricacies of administrative paperwork, deadlines, and applications. Her patience, expertise, and dedication was greatly appreciated. To Dr. Nick Hyrnyk, who as a fellow student, and then graduate, helped guide me through the process of the comprehensive exam and the research and writing of a dissertation. His friendship, and success as an academic, is my inspiration. To my other close friend, Chase Ferguson, thank you for always being there with me during the good and the bad. Alana Toulin, Erin Gurski, Anna Kuntz, Oli Anderson, Matt Hintermann, and Kathleen Burns, thank you for your support and encouragement. Professor Dominque Marshall, a devoted teacher, first introduced me to the subjects that would form my research project, and as an examiner showed me there is much more to be done. Professor Paul Litt taught me the importance of political history and his vigorous examination of my dissertation challenged me to think of my work in new ways. Thank you to Professor Wallace Clement, whose personal insight into my research project was extremely helpful and enlightening during the defence. And to Professor Dimitry Anastakis: thank you for serving as my external examiner, your 
insight, praise, and criticism were much appreciated and inspired me to continue to improve my work and expand my outlook.

I would not be writing these acknowledgements if were not for my supervisors Professor Norman Hillmer, CM, and Professor Stephen Azzi. Thank you for putting up with me as I navigated the trials and tribulations of writing a dissertation. To Stephen Azzi: your dedication to your work as a supervisor was admirable and you always knew how to find the right words and thoughts when I was ready to give up all hope. To Norman Hillmer: my close friend and confidant, I am immensely grateful for your support and dedication over the years, you were there for me during the highs and lows of both graduate school and life. I will always cherish the time we spent together in the classroom, on walks, drives, at antique and book stores, and most of all at lunch and dinner, they were the highlight of my time as a graduate student.

To my family, thank you to my mom and dad, Vincenza and Augusto, for believing in me all my life and supporting me in my long academic journey, words cannot describe my gratitude. To my sister Vanessa, you always insisted I follow my dreams. Finally, to my grandparents Vittorio and Gina, while you passed away before I was able to finish my $\mathrm{PhD}$, I have comfort knowing that you would be proud of me. To my Nonno Cesare, you were always a big part of my life even though I never got to meet you. And to my Nonna Rosa, you have always been there for me, and your life journey is my inspiration. Successfully completing a PhD requires a lot of effort and sacrifice, and my grandparents who upended their lives to move to Canada have been my role models. It is to them that I dedicate this thesis. 


\section{Table of Contents}

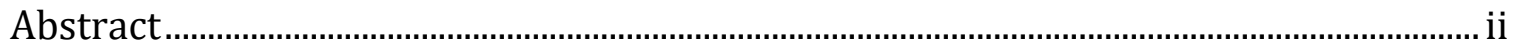

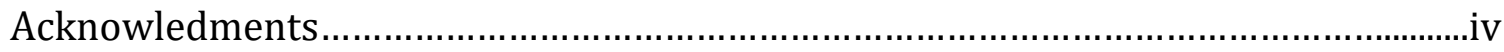

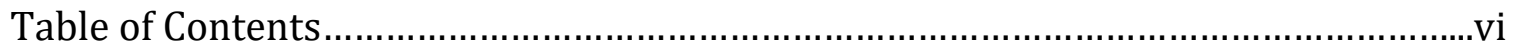

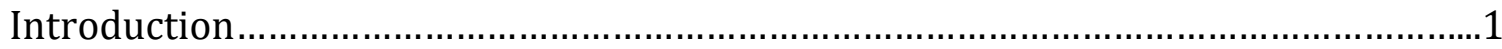

Chapter 1: The New Democratic Party and the Rise of the Waffle, 1968-1969.......... 34

Chapter 2: The Waffle's Populist Aspirations and Anti-Imperialist Agenda, 1969-

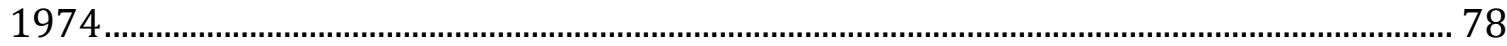

Chapter 3: Confronting American Dependency and Decline, 1970-1974 ..................134

Chapter 4: The Politics of Energy, Ecological Independence, and the "End of Canada,"

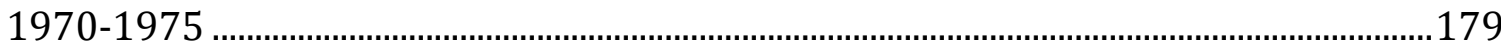

Chapter 5: Left Nationalists, Neo-Marxists, and the New Canadian Political Economy,

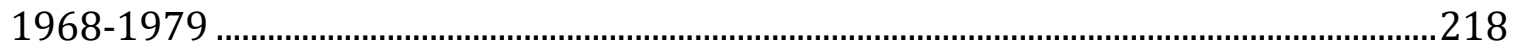

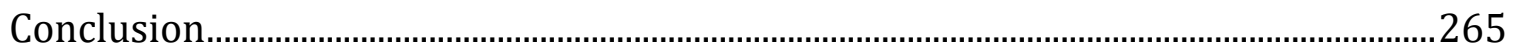

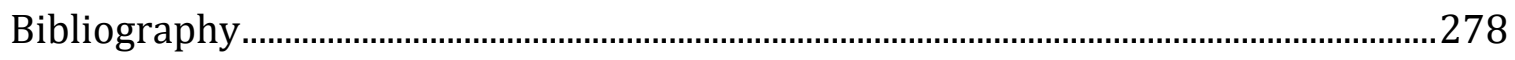




\section{Introduction}

In the late 1960s and through the 1970s, left nationalism flourished in English Canada. This dissertation is an inquiry into the political and intellectual currents of that call for action. It investigates the reasons why left nationalism emerged as a major force in English Canadian left politics and explores the evolution of a neo-Marxist critique of both Canadian capitalism and Canada's relationship with the United States. ${ }^{1}$ English Canadian left nationalism had a political manifestation in the Waffle movement and an intellectual manifestation in the New Canadian Political Economy. It represented a distinctive perspective and political agenda. Its vision was of a Canada divorced from the American-led capitalist world system.

The dissertation demonstrates that the left-nationalist interpretation of Canadian-American relations was rooted not in anti-Americanism, but in a radical politics of democratic socialism and anti-imperialism. Left nationalism was primarily the product of neo-Marxist thought, rather than a reaction to problems in American politics, society, and foreign policy. English Canadian left nationalists were disruptors who, unlike their New Nationalist contemporaries, did not advance a program of capitalist or social democratic reform. The left nationalists were determined to replace capitalism with democratic socialism; without socialism, there could be no Canadian independence. Left nationalists sought to end Canada's colonial status in the declining American empire, viewed the preservation of

\footnotetext{
${ }^{1}$ In contrast to classical Marxists, neo-Marxists were primarily concerned with political and social relations, rather than class and economics. Neo-Marxism was an extension of the New Left. NeoMarxist theorists were concerned with the paradox of Marxism: its failure in the developed world, but its success in underdeveloped countries.
} 
Canada's resources as imperative to the country's long-term prosperity, and advanced neo-Marxism in the academy. The dissertation interrogates internal debates within the New Democratic Party over how to respond to the problem of American dependency; the rise and fall of the Waffle movement; the left nationalist response to crises in Canadian-American relations during the late 1960s and early 1970s; and the establishment of the New Canadian Political Economy, left nationalism's most enduring legacy.

As Norman Hillmer and Adam Chapnick contend, Canada had no single or static twentieth-century nationalist ideology. ${ }^{2}$ Instead, nationalism took many different forms in various contexts and was espoused by certain groups for a myriad of reasons. The left nationalism studied in this dissertation represents one form of Canadian nationalism. Left nationalists, an assortment of political activists and academics outside mainstream politics and academia, sought to advance the politics of democratic socialism, which called for the replacement of capitalism with socialism through public ownership of key sectors of the economy and greater worker rights along with the preservation of national independence. ${ }^{3}$ The period covered by this thesis, 1968-1979, was one of peak nationalism, when the preservation of Canadian independence in the face of economic dominance by the

\footnotetext{
2 Norman Hillmer, and Adam Chapnick, "An Abundance of Nationalisms," in Canadas of the Mind: The Making and Unmaking of Canadian Nationalisms in the Twentieth Century, ed. Norman Hillmer and Adam Chapnick (Montreal: McGill-Queen's University Press, 2007), 5

${ }^{3}$ The democratic socialist agenda advanced by the left nationalists contrasted with the social democratic platform of the federal New Democratic Party. Where democratic socialists advocate the replacement of capitalism with democratic and collective ownership of industry, social democrats advocate reform to temper the worst excesses of capitalism such as the expansion of the welfare state.
} 
United States was a matter of paramount concern to Canadian activists, academics, and politicians.

Mel Watkins, a prominent left nationalist, described the 1970s as "a nationalist interlude" between Canada's "special status in the American Empire" during the 1950s and 1960s and the "Reagan-Mulroney era of the 1980s, with Canada being an exemplary-client state." ${ }^{4}$ This dissertation examines the nature of left nationalism through an analysis of the English Canadian left's critique of Canadian political economy and Canada's relationship with the United States during the nationalist period that dated from approximately 1968 to 1979. Left nationalists were a distinctive group in the wider English Canadian nationalist movement who sought the transformation of a Canadian federal party, the New Democratic Party (NDP), into one that was unequivocally of the democratic socialist left. In turn the NDP would remake Canada into an independent socialist country. This dissertation studies the course and canon of left nationalism in the English Canadian left during this period of tumult and change, and the extent to which the NDP was used as a vehicle by left nationalists to disseminate these ideas.

When journalist Walter Stewart asked Watkins if he wanted to "smash everything and start again," he readily agreed. ${ }^{5}$ This sentiment, the tearing down of the Canadian economy and rebuilding it along socialist lines, was the unifying theme of the left-nationalist movement. Left nationalists were not reformers; they were

\footnotetext{
4 Mel Watkins, "The Waffle and the National Question," Studies in Political Economy 32 (1990), 132. ${ }^{5}$ Walter Stewart, "On the Left, Mel Watkins. In the Middle, Joe Greene. The Heavyweight Contest to Choose Captain Canada of 1971," Maclean's, 1 November 1970, 35.
} 
disruptors who employed populist rhetoric. ${ }^{6}$ They were active in politics and the academy, primarily the Waffle Movement and the New Canadian Political Economy. Left nationalists had an anti-imperialist worldview, arguing that Canada was trapped in a colonial relationship with the United States. They insisted that the only effective means of liberating Canada was to adopt democratic socialism. Their perspective was revolutionary. This sentiment differentiated them from other nationalists on the left, such as Abraham Rotstein, who also had qualms about capitalism, but sought to reform rather than overthrow the economic system. All nationalists of the time agreed that Canada's dependence on the United States represented an existential crisis.

The dissertation is interested in how the left nationalist political project differed politically and intellectually from the New Nationalism. Left nationalism was in contention with New Nationalism which emerged as a reaction against continentalism, the support of economic integration and close ties with the United States, which by the 1960s dominated many elements of Canada's business and political elite. ${ }^{7}$ Left nationalists positioned themselves against the New Nationalists,

\footnotetext{
${ }^{6}$ Populism refers to anti-elitist sentiment aimed at mainstream or establishment politicians or institutions. Populists often portray their agenda as being for the people over the elites. There are left-wing and right-wing varieties of populism, but an overarching theme is the claim to speak on behalf of ordinary people who have been wronged by the political establishment. See Manuel Anselmi, Populism: An Introduction (London: Routledge, 2018). According to political scientist David Laycock, left-wing populism in English Canada was prevalent in the prairies since the 1930s. According to Laycock, political parties such as the United Farmers of Alberta and the Cooperative Commonwealth Federation based their platforms on left-populism and advanced an agenda of direct-democracy and worker control of industry to build a coalition of farmers and workers against entrenched business interests. See, David H. Laycock, Populism in Democratic Thought in the Canadian Prairies (Toronto: University of Toronto Press, 1990).

${ }^{7}$ Some examples of the literature on continentalism include Dimitry Anastakis, "Between Nationalism and Continentalism: State Auto Industry Policy and the Canadian UAW, 1960-1970," Labour/Le Travail 53 (Spring 2004), 89-126; Graham Carr, "'All We North Americans:' Literary Culture and the Continentalist Ideal, 1919-1939," American Review of Canadian Studies 17 (1987),
} 
claiming that their comparatively moderate economic nationalism constituted reformist capitalist half-measures. Cy Gonick, the editor of Canadian Dimension and a strong proponent of left nationalism, referred to the moderates dismissively as the “Toronto Star - Walter Gordon - Abraham Rotstein Axis," a reference to Toronto's largest-circulation newspaper, a wealthy Toronto businessperson and former politician, and a left-leaning University of Toronto economist. ${ }^{8}$ The New Nationalist program of buying back the Canadian economy served the interests of Toronto elites and did not directly confront the true problems of capitalism or American imperialism.

The dissertation's argument that left nationalism was distinctive from New Nationalism represents a departure from the historiography on English Canadian economic nationalism. Historians such as Stephen Azzi contend that the left nationalism under study in this dissertation constituted a leftist expression of the New Nationalism. Specifically, Azzi argues that the New Nationalism was not homogenous and represented two distinct streams, with one side focussed on opposing American influence, and the other American capitalism. ${ }^{9}$ Other historians such as Ryan Edwardson are less specific in their treatment of New Nationalist politics. Edwardson used New Nationalism as an umbrella term for all those who

145-57; Norman Hillmer, “O. D. Skelton and the North American Mind," International Journal 60, no. 1 (Winter 2004-05), 93-110; Allan Smith, "Doing the Continental: Conceptualizations of the CanadianAmerican Relationship in the Long Twentieth Century," Canadian-American Public Policy 44 (2000), 2-70; and Reginald Stuart, "Continentalism Revisited: Recent Narratives on the History of CanadianAmerican Relations," Diplomatic History 18 (1994), 405-14.

${ }^{8}$ Cy Gonick, "Liberal-izing Continentalism," Canadian Dimension 7, no.4 (Oct.-Nov. 1970), 4.

${ }^{9}$ Stephen Azzi, "Foreign Investment and the Paradox of Economic Nationalism," Canadas of the Mind: The Making and Unmaking of Canadian Nationalisms in the Twentieth Century, ed. Norman Hillmer and Adam Chapnick (Montreal: McGill-Queen's University Press, 2007), 76. 
advocated measures limiting American investment and cultural influence in Canada. ${ }^{10}$ This dissertation does not refute the argument that New Nationalism had many political expressions. However, it does draw attention to how other leftist figures positioned themselves in the nationalist movement. The left nationalists studied here premised their agenda on advancing democratic socialism, antiimperialism, and in some cases populism and Marxism. They claimed that their agenda was the only way forward, and that the economic nationalist program advanced by their comparatively moderate counterparts was insufficient to the task of remaking Canada into an independent socialist country. They dismissed New Nationalism as incompatible with, and in some instances even hostile, to their agenda.

According to political scientist Benedict Anderson, nationalism is often used by elites to serve their purposes. New Nationalists fit this description. ${ }^{11}$ Prominent New Nationalists of the 1960s and 1970s were the businessperson and politician Walter Gordon, novelists Margaret Atwood and Farley Mowat, economist Abraham Rotstein, historian Donald Creighton, and professors of English Robin Mathews and James Steele. ${ }^{12}$ This group shared a desire for the preservation of Canadian sovereignty in culture and economics. The New Nationalism was also reflective of anti-American sentiment. As historian Paul Litt has argued, many of these

\footnotetext{
${ }^{10}$ Ryan Edwardson, “Kicking Uncle Sam out of the 'Peaceable Kingdom': English Canadian New Nationalism and Americanization," Journal of Canadian Studies 37, no. 4 (Winter 2002-2003), 133-34. ${ }^{11}$ See Benedict Anderson, Imagined Communities: Reflections on the Origin and Spread of Nationalism (London: Verso Books, Expanded Edition, 2010).

12 For an account of Walter Gordon's career and New Nationalist politics, see Stephen Azzi, Walter Gordon and the Rise of Canadian Nationalism (Montreal: McGill-Queen's University Press, 1999). On the New Nationalists and the "Canadianization movement," see Jeffrey Cormier, The Canadianization Movement: Emergence, Survival and Success (Toronto: University of Toronto Press, 2004).
} 
nationalists believed that American problems like the violent opposition to the civil rights movement, the nuclear arms race, pollution, urban riots, and Vietnam "showed Canada to be the morally superior North American liberal democracy."13 This attitude towards the United States was a unifying theme of the New Nationalism.

The New Nationalism was neither imposed from above nor represented a mass-driven revolutionary movement. Instead, as Edwardson contends, it was a “middle-class renegotiation of Canada's postcolonial direction that challenged the continentalist elites in the Liberal Party and the business community." 14 Stephen Azzi was more specific, describing New Nationalist sentiment as supportive of an interventionist approach to the economy, with its strongest support in Southern Ontario, "the area that could most afford to be discriminating about future [foreign] investment." 15 This dissertation does not directly study the New Nationalists, except for instances when they were in direct contention with the left nationalists. While many New Nationalists were concerned with protecting Canadian business, high culture, and universities from American control and influence (often referred to as Americanization), left nationalists wanted to overturn Canadian left politics by expressing anti-imperialist sentiment, advancing a democratic socialist agenda, and importing neo-Marxism.

The late 1960s and early 1970s marked a period of economic upheaval and tension in international relations, as the United States faced economic decline.

\footnotetext{
13 Paul Litt, Trudeaumania (Vancouver: UBC Press, 2016), 3.

14 Edwardson, “Kicking Uncle Sam out of the 'Peaceable Kingdom,'” 134.

15 Azzi, "Foreign Investment and the Paradox of Economic Nationalism," 77.
} 
During this period, the English Canadian left characterized the Canadian-American relationship as a symptom of the problem of Canadian political economy: an advanced capitalist country that was dependent on the United States for prosperity and security. The left nationalist agenda was influenced by the introduction of neoMarxist ideas by academics preoccupied with reinvigorating socialism and seeking an alternative to Canada's relationship with the United States. Emergent Canadian neo-Marxists, some of whom were practitioners of the New Canadian Political Economy, such as Leo Panitch, Kari Levitt, Thomas Naylor, and Wallace Clement, challenged prevailing orthodoxies through a critique of the capitalist system that underpinned the American-led international order. They argued that Canada's dependence on the United States both for economic prosperity and national security meant that it was impossible for the country's leaders to pursue a foreign policy that was truly independent without making a dramatic break from the status quo.

Left nationalists based their political project on opposition to capitalism, American imperialism, and the Canadian capitalist elite's relations with their American counterparts. Using populist rhetoric that railed against elites, multinational corporations, and the NDP establishment, left nationalists expressed a desire to remake Canada's political economy into one based on democratic socialism, freeing the country from its colonial relationship with the United States. Left nationalists disagreed over which should be prioritized, democratic socialism or independence, but they were ultimately united by a shared anti-capitalist and anti-imperialist impulse. 
Anti-imperialism provided a major unifying theme for left nationalism. This sentiment shaped left nationalist views of the United States and Canada's relationship with it. In Canada's case, anti-imperialism was a comprehensive term that included all those who embraced a program of liberation from the American empire. Left nationalists were particularly attuned to anti-imperialist thinking. Marxists associated with left nationalism were anti-imperialist because they viewed imperialism as an extension of capitalism. According to this reasoning, the United States, as a capitalist superpower, was undoubtedly imperialist. Canada, economically dependent on the United States, was therefore a colony in needed of liberation. ${ }^{16}$ Out of this outlook emerged a concern for Canada's place in the American-led world order. Left nationalists feared that Canada's colonial or dependent situation was also made more acute by the decline of the United States as a world power. Cy Gonick described a crisis in the American empire: "an energy crisis burst on the scene in the winter of 1973 and a food crisis in the summer, accompanied by the wildest inflation in recent history and the catastrophic collapse of the American dollar. While the United States was squandering its resources on imperial adventures and military bases on all corners of the globe, its rivals gathered their strength." 17 In Gonick's view, Canada faced two existential crises of its own in its relations with the Americans: Canada's sovereignty was threatened by its colonial status and its future was threatened by American economic decline.

\footnotetext{
16 This anti-imperialist sentiment or worldview can be traced to the writings of the English economist John A. Hobson, who in 1902 argued that capitalism formed the basis of imperialism. V. I. Lenin expanded on Hobson's ideas and argued that imperialism was the highest stage of capitalism. Anthony Brewer, Marxist Theories of Imperialism: A Critical Survey (London: Routledge, 1990), 21. ${ }_{17}$ Cy Gonick, Inflation or Depression: The Continuing Crisis of the Canadian Economy (Toronto: James Lorimer, 1975), 16.
} 
English Canadian left nationalists developed a new interpretation of the CanadianAmerican relationship that was not dependent on anti-Americanism or liberal reformism, as was the New Nationalism, but on democratic socialism politically and neo-Marxism intellectually.

George Grant, the anti-American Tory intellectual whose Lament for a Nation (1965) influenced a new generation of nationalists, claimed that Canada had been absorbed into American technological civilization. According to Grant, the continentalist elites of the Liberal party conspired to bring down the John Diefenbaker government (1957-63), which had attempted to resist American influence. ${ }^{18}$ Grant's analysis affected the growing nationalist movement in English Canada, made up of a coalition of Canadian thinkers and politicians who sought to stave off, or reverse Canada's domination by the United States.

After the publication of George Grant's Lament for a Nation in 1965, it was clear that many leftists viewed the United States as detrimental, even dangerous, to Canada's short- and long-term prospects. By the end of the 1960s, the left saw the United States as staunchly anti-Communist, militaristic, and reactionary. James Laxer illustrated how the leftist view of the United States and Canada's relationship with that country had changed by 1970 . "For Canadians who wish to pursue the elusive goal of an egalitarian socialist society, Laxer wrote in Close the 49th Parallel,

${ }^{18}$ George Grant, Lament for a Nation: The Defeat of Canadian Nationalism (Toronto: McClelland and Stewart, 1965), 26. 
"American imperialism is the major enemy."19 Canadian leftists, maintaining their anti-imperialist sentiment, had turned decisively away from the United States.

Marxism and the English Canadian Left Prior to the 1970s

During the 1960s a new generation of leftists outside the orbit of the central Canadian political and business elite re-evaluated their views of the United States and Canadian-American relations. Grant's Lament for a Nation proved pivotal in influencing a new generation of leftists to take up the mantle of nationalism. James Laxer, a leader of the left nationalists, called Lament for a Nation "the most important book I ever read in my life. Here was a crazy old philosopher of religion at McMaster and he woke up half our generation. He was saying Canada is dead, and by saying it he was creating the country." ${ }^{20}$ Laxer's words were a clear indication that the Canadian left embraced nationalism as part of its political agenda.

Canadian Marxists also had to contend with the national question. On the surface leftist politics might seem incompatible with a Canadian nationalist agenda. Leftists, however, were caught up in the nationalist fervour of the 1960s. In contrast to the New Nationalists, who premised their nationalist sentiment on the liberalcentrist politics of capitalist reformism and sometimes anti-Americanism, the left nationalists were concerned with advancing a socialist agenda as a means of addressing the issue of Canadian independence. At the same time as the rise of New

\footnotetext{
${ }^{19}$ Gerald L. Caplan and James Laxer, "Perspectives on Un-American Traditions in Canada," in Close the 49 th Parallel etc.: The Americanization of Canada, ed. Ian Lumsden (Toronto: University of Toronto Press, 1970), 310.

${ }^{20}$ James Laxer, quoted in Charles Taylor, Radical Tories: The Conservative Tradition in Canada (Toronto: House of Anansi Press, 1982), 148.
} 
Nationalism, there was an emergence of a neo-Marxist school of thought in the academy, which caused a divergence of the nationalist camp between those who wanted to establish a Marxist tradition, and those who did not. While questioning Canada's relationship with the United States had become a national pastime, at the same time left nationalists grew concerned about the lack of Marxism and socialism in Canadian scholarship and politics.

According to historian Ian McKay, the Canadian left had four distinct paths in which its thought and politics were shaped by specific local and global conflicts. The third path occurred during the 1960s and 1970s and dealt with the "three-part national question": "whether Canada should exist as an independent country," the Quebec independence issue, and the place of Indigenous people in the Canadian nation. For McKay the Waffle movement constituted a "a powerful form" of the Canadian left's attempt to grapple with the first of these questions. ${ }^{21}$ Situating the Waffle movement as part of the wider history of Canada's left, as McKay does, is one of the main aims of this dissertation.

Left nationalists were undoubtedly preoccupied with the national question, but many were also concerned with a lack of Marxism in Canada. In the history of the English Canadian left, Marx only made sporadic appearances prior to the 1960s. Canadian socialism can be traced to the late 1890s, but it was overwhelmingly reformist rather than revolutionary, and continentalist rather than nationalist. As McKay contended, turn-of-the-century Canadian socialists were more influenced by

${ }^{21}$ Ian McKay, Rebels, Reds, Radicals: Rethinking Canada's Left History (Toronto: Between the Lines, 2005), 40. 
Edward Bellamy's novel Looking Backwards, with its vision of an enlightened, egalitarian, and equal society, than by the Marx-Engels Communist Manifesto. ${ }^{22} \mathrm{As}$ internationalists and continentalists, many of these early Canadian socialists were deeply influenced by their counterparts in the American socialist movement. ${ }^{23}$ Initially, the Canadian left relied on the support of those American socialist organizations that established branches in Canada. The American-based Socialist Labor Party created the first major network of socialist organizations in Canada and ran candidates at municipal elections. By 1900 Marxists began to exert influence in Canadian socialist circles but were often in conflict with the reformists and Protestant ministers who played a major role in the growth of English Canadian left politics. Reformists and the Social Gospel movement regarded Marxism with suspicion or even disdain, and the early socialist organizations in Canada suffered from major infighting and splits that exiled the Marxists to the sidelines of mainstream left politics. ${ }^{24}$

Marxism briefly experienced an efflorescence in Canada during the years surrounding the 1917 Bolshevik Revolution in Russia and the 1919 Winnipeg General Strike. These events, alongside the founding of the Communist Party of Canada in 1921, marked a left turn in the history of Canadian socialism. However, this communist moment of revolutionary fervour and radical rhetoric was shortlived. A new phase in left history began with the founding of the League for Social

\footnotetext{
22 McKay, Rebels, Reds, Radicals, 149.

${ }^{23}$ There were "Bellamyist clubs" in Toronto, and the first explicitly socialist organization in Canada, the Socialist Party of British Columbia, viewed itself as a counterpart of the Socialist Party of America. ${ }^{24}$ As McKay observed, "the first homegrown socialist movement with dominion-wide ambitions was the Canadian Socialist League (CSL) founded in 1899."Ibid., 151.
} 
Reconstruction (LSR) in 1931, and the Cooperative Commonwealth Federation (CCF) in $1932 .{ }^{25}$ The CCF quickly replaced the Communists as the dominant party of the left, and, as a result, revolutionary Marxism was sidelined. The CCF's political agenda won some support at the polls at the federal level and had more success in provincial politics, especially in Saskatchewan where the party gained power and kept it for a long time. The party repeatedly clashed with the Communists, especially during the early Cold War years of the late 1940s and early 1950s. The CCF eschewed revolutionary politics and democratic socialism in favour of social democratic reformism, described by Geoff Eley as "radical plannism," which sought a way of transforming the state into a socialist one. ${ }^{26}$ This differed from conventional Marxism or communist ideology as it called for the reform, rather than the overthrow, of the state.

By the 1950 the CCF was in the political doldrums and the Canadian Labour Congress sought to create a new political party that would be more moderate and appeal to liberal minded voters. ${ }^{27}$ In 1961 the CCF was relaunched as the New Democratic Party with a platform that embraced left liberalism rather than Marxist democratic socialism. This new era, characterized by moderate reformism, coincided with the rise of nationalist sentiment in English Canada. Almost

\footnotetext{
25 Tasked with crafting the CCF's electoral platform, the LSR was led by left-continentalist intellectuals in Montreal and Toronto, such as Frank Underhill, F. R. Scott, and Eugene Forsey who wanted Canada to adopt an economic program similar to that of United States President Franklin Roosevelt's New Deal. Ibid., 171.

${ }^{26}$ Geoff Eley, Forging Democracy: The History of the Left in Europe (London: Oxford University Press, 2002), 240-41.

27 This was understandable from the CCF's perspective as the 1950s witnessed a major decline in their popular vote in successive elections. Canadian voters were in favour of Canada's participation in the Cold War and saw little need for radical plannism.
} 
immediately after the party's founding, two political trends challenged the NDP's moderate agenda: the rise of nationalism and the birth of the international New Left.

1968: The New Left, Dependency Theory, and Left Nationalism

The 1960s were a decade of upheaval, change and transformation, while the 1970s were a period of reckoning, as the world economic system suffered a series of crises. By the late 1960s a new form of leftism emerged globally. This New Left differed from the old in that it was concerned less with the exploitation of the working class and more with a liberation agenda that encompassed decolonization and anti-imperialism. Unlike the old left, the New Left worked outside partisan political parties. (The term New Left was coined by the British journal, New Left Review, established in 1960). The New Left gained prominence in 1968 after a series of failed uprisings in Europe, particularly in Czechoslovakia (known as the Prague Spring), along with widespread university student-led protests throughout the world, notably in May 1968 in France. With the failure of the 1968 revolutions in France and Czechoslovakia, New Leftists denounced social democracy as having become too bourgeois (middle-class), and communism as obsolete. ${ }^{28}$ Their agenda was based on creating a society that was more participatory, anti-elitist, and consensual. New Leftists had little patience for central planning or middle-class politics. New Leftists were concerned with liberation, which meant a myriad of things to many different groups. In English Canada, it meant the liberation of the nation from control by the Americans, or from English Canada in the case of Quebec.

28 McKay, Rebels, Reds, Radicals, 183. 
Many Canadian New Leftists in both English and French Canada saw their agenda as one of decolonization based on an anti-imperialist world view. They did agree with the New Nationalists that Canada was dependent on the United States, but they went further, claiming that Canada was a colony of the American empire, a situation that was enabled by capitalism. ${ }^{29}$ As historian David S. Churchill wrote, "the conceptualization of the United States as a modern empire was a core component of the New Left's political critique, one that questioned the rationale of international anti-communism while at the same time rehabilitating older Marxist critiques of imperialism." ${ }^{30}$ In short, capitalism, not Americanization, was the primary problem facing Canada, and American dependency would not be addressed by expanding Canadian corporate ownership or buying back the economy. Left nationalists held that the country's colonial status resulted from the capitalist system that the New Nationalists aimed to preserve.

Out of this concern with decolonization, anti-imperialism, and liberation emerged left nationalisms around the globe. Successive liberation movements in the Middle East, Asia, Africa, and Latin America sought mass support through employing a leftist agenda, or at least leftist language. The transformation of left politics was accompanied by a reinvigoration of Marxism. Marxism faltered in Western Europe and the United States, but at the same time it gained popularity in Asia and Africa, following from the politics of nationalism and anti-imperialism. In the

\footnotetext{
${ }^{29}$ David S. Churchill adopts a broad definition of left nationalism, as constituting all those on the left who "interpreted the relationship between Canada and the United States in neo-colonial and postcolonial terms." David S. Churchill, "Draft Resisters, Left Nationalism, and the Politics of AntiImperialism," The Canadian Historical Review 93, no. 2 (June 2012), 233.

${ }^{30}$ Ibid., 241.
} 
underdeveloped world, students, labour leaders, and intellectuals sought to align Marxism with nationalism (or national liberation) as a means of gaining mass support for their campaign against their colonial overlords. In this sense they were inspired by the Marxism-Leninism of the Soviet Union, with its triumph over Nazism and resistance to the Americans in the Cold War. ${ }^{31}$ Revolutionary Marxism, or Marxism-Leninism, was dismissed as irrelevant in Western Europe and the United States since, barring a major crisis, no one seriously believed there would be a proletarian revolution. As a result, attention shifted to the colonized underdeveloped world where peasants and workers were deemed to be oppressed by capitalists and imperialists.

As left nationalists quickly realized, political decolonization did not necessarily bring economic liberation. Post-colonial countries remained in a state of dependence and underdevelopment after imperial bonds were severed in the 1950s and 1960s. No longer concerned with the economic plight of the working-class, Marxist economists in advanced industrialized nations turned to studying the persistence of colonial economic and social arrangements in underdeveloped economies, and characterized the phenomenon as "underdevelopment," "neocolonialism," or "dependency." ${ }^{32}$ Political economists' concern with dependency and underdevelopment emerged in the mid 1950s as a method of studying Latin

\footnotetext{
31 Gregory Claeys, Marx and Marxism (London: Pelican Books, 2018), 413-14.

32 For examples of Frank, Prebisch, Sweezy, and Wallerstein's writings on dependency see, Paul A. Baran, The Political Economy of Growth (New York: Monthly Review Press, 1957); Andre Gunder Frank, The Development of Underdevelopment: Historical Studies of Chile and Brazil (New York: Monthly Review Press, 1966); Raúl Prebisch, The Economic Development of Latin America and Its Principal Problems (New York: United Nations, 1950); Paul Sweezy, The Theory of Capitalist Development (London: D. Donson, 1949); Immanuel Wallerstein, The Capitalist World Economy (Cambridge: Cambridge University Press, 1979).
} 
America. Dependency theory was first proposed by the Director of the United Nations Economic Commission for Latin America, Raúl Prebisch, who was concerned with the reasons why the rapid growth of advanced industrialized economies did not lead to corresponding growth in underdeveloped countries, and in some cases made the situation worse. The theory was quickly popularized by the 1957 publication of Paul A. Baran's The Political Economy of Growth. Baran's study was followed by other works by practitioners of dependency theory such as Paul Sweezy, Andre Gunder Frank, and Immanuel Wallerstein.

Dependency theory sought to address the causes and consequences of the persistence of colonial relationships and contended that the post-colonial world was divided between two sets of states; namely, the core and periphery (often referred to as metropolitan-hinterland, or dominant-dependent). The relationships between these two groups of states were mostly determined by external factors such as trade, foreign aid, and investment by multinational corporations. This dependence was part of the long historical process of the development of capitalism. ${ }^{33}$ Despite dependency theorists' assertion that decolonization and nationalism did not liberate the workers trapped in a dependent economy, orthodox (or classical) Marxists were receptive to the claim that dependence was brought about by capitalism. Socialism was the only means of liberating the working class.

The development of global left nationalisms and concern with dependency had major ramifications for Canadian left politics. While many Quebec New Leftists

\footnotetext{
33 Vincent Ferraro, "Dependency Theory: An Introduction," in The Development Economics Reader, ed. Giorgio Secondi (London: Routledge, 2008), 58-9.
} 
helped found what was to be the province's sovereignist movement, English Canadian New Leftists' created the Waffle Movement in the NDP. The Waffle's program of advancing decolonization through socialism represented a uniquely Canadian New Left phenomenon. The Waffle broke with the reformist trajectory of Canadian left politics and called for the NDP to be remade into an unreservedly socialist party. For the Waffle, socialism meant an agenda of nationalization of industry to place ownership of Canadian resources and manufacturing in Canadian hands. Unlike the New Nationalists and many in the NDP concerned with American dependency, the Waffle wanted an economy controlled by Canadian workers, not domestically based capitalists. Canada was a colony because of its capitalist system. Socialism was the only effective means of achieving decolonization.

Despite these assertions, left nationalists concerned with Canadian-American relations and Canada's place in the world economic system found that Canada did not easily fit into the core or periphery categories. Initially, the left nationalist's embrace of dependency theory seems peculiar, as Canada was in many respects an advanced industrialized economy, which on the surface bore little resemblance to the periphery countries studied by dependency theorists. Canada, they argued, was in the unique position of being a semi-periphery country, positioned between the core of the United States and periphery of the developing world. ${ }^{34}$ The country was

\footnotetext{
34 The world systems theory, which was later developed out of dependency theory in the 1970s by the political scientist Immanuel Wallerstein, provides a good definition of a semi-periphery country. Wallerstein accepted the dependency theorists' assertion that the world was divided into the categories of core, semi-periphery, and periphery. Semi-periphery countries were those that were developed and industrialized but dependent on foreign investment and export to core countries. While Wallerstein did not characterize Canada as semi-peripheral, left nationalists insisted that Canada was semi-peripheral because of its dependence on the United States. Immanuel Wallerstein, "Semi-Peripheral Countries and the Contemporary World Crisis in the Capitalist World Economy," in
} 
in many respects advanced and industrialized, but dependent on trade and investment from the United States, and had a business sector dominated by multinational corporations.

Left nationalists embraced dependency theory as a means of addressing Canada's status as a semi-periphery country and in a colonial relationship with the United States. ${ }^{35}$ This was especially the case in Quebec. As historian Sean Mills demonstrated, decolonization became widely popular in Quebec nationalist circles because French-Canada was regarded as being in a state of colonial subjugation by the English Canadian capitalists who dominated Montreal. The situation was different in English Canada where left nationalists were worried about Canada's economic prosperity and development being dependent on the United States. Left nationalists regarded Canada, or Quebec, as a colony in need of liberation. In the words of economist Kari Levitt, an influential dependency theorist, this relationship with the United States had led to Canada's "silent surrender." ${ }^{36}$ In this view, Canada was the victim of American neo-colonialism and unable to fully develop into a core country. Canada's status as an American colony was the result of Canada's dependence on exporting staples and American foreign investment in the form of branch plants and multinational corporations.

Essays by Immanuel Wallerstein, ed. Immanuel Wallerstein (Cambridge: Cambridge University Press, 1979), 96.

${ }^{35}$ Sean Mills, The Empire Within: Postcolonial Thought and Political Activism in Sixties Montreal (Montreal: McGill-Queen's University Press, 2010).

${ }^{36}$ Kari Levitt, Silent Surrender: The Multinational Corporation in Canada (Toronto: Macmillan of Canada, 1970), 24-5. 
The Literature of Canadian Left Politics

This dissertation studies the development of left nationalist thought in English Canada through an analysis of an emergent canon of political and intellectual discourse. Left nationalist writings were distinct from those of the New Nationalists, advancing an anti-imperialist worldview, socialist political agenda, and a departure in the study of political economy. Attention in the dissertation is centred on publications that identify a left nationalist tradition in English Canadian politics and academia in the late 1960s and 1970s. Historians and political scientists have done extensive work on the Waffle movement and the New Left in Canada, but they have not documented the development of an explicit left nationalism or drawn attention to its legacy in the creation of the New Canadian Political Economy. The examination of the key texts produced by left nationalists, instead of a concentration on the rise and fall of the Waffle or the New Left's interaction with party politics, allows for a fresh understanding of the course, trajectory, and significance of left nationalism in English Canada.

For left nationalism to succeed politically, it needed to have academic foundations. Crucial sources for this dissertation were the writings of prominent left nationalist figures such as Mel Watkins and James Laxer and published works of their colleagues and contemporaries found in edited collections such as Close the 49th Parallel Etc. (1970) and (Canada) Ltd. (1973). ${ }^{37}$ These and other sources

\footnotetext{
${ }^{37}$ Ian Lumsden, ed., Close the 49th Parallel Etc.: The Americanization of Canada (Toronto: University of Toronto Press, 1970); Robert Laxer ed., (Canada) Ltd.: The Political Economy of Dependency, ed. Robert Laxer (Toronto: McClelland and Stewart, 1973).
} 
revealed the currents, outlooks, and aspirations of left nationalists. The writings of the New Canadian Political Economists were examined in depth and demonstrated the extent to which the politics of left nationalism influenced intellectual trends and academic debate. All these sources reveal that left nationalism constituted a diverse set of beliefs and agendas attuned to the politics of the tumultuous nationalist interlude. They offer a window into the minds of English Canadians who sought a political and economic alternative to American dependency during a period of crisis and transformation in Canada's political economy and relationship with the United States.

Much of the historiography of the New Left in the 1960s was initially preoccupied with narratives of the movement's rise and decline. Some scholars of 1960s activism, such as the American historian Todd Gitlin, advanced a narrative of decline in New Left power and influence after $1968 .{ }^{38}$ Early historians of the Canadian 1960s mostly followed this interpretation, arguing that the 1970s witnessed the defeat of the New Left. In Born at the Right Time, Doug Owram wrote of an early Sixties idealism held by the baby boom (postwar) generation that was replaced by polarization, repression, and decline by the end of the decade. ${ }^{39}$ Cyril Levitt in, Children of Privilege, argued that the Sixties protest movement was led by disillusioned students who revolted against privilege. As the baby boomer students grew up their protest movement retreated into the university campuses by the late

\footnotetext{
38 Todd Gitlin, The Sixties: Years of Hope, Days of Rage (New York: Bantam Books, 1987).

${ }^{39}$ Doug Owram, Born at the Right Time: A History of the Baby Boom Generation (Toronto: University of Toronto Press, 1996), 160.
} 
1960s and then faded away into irrelevance by the early 1970s. ${ }^{40}$ For Gitlin, Owram, and Levitt, the idealism of the 1960s became the defeat of the New Left in the 1970s.

Recent studies on the Canadian New Left have challenged the declinist narrative and instead concentrated on studying the legacies of specific New Left movements. An example of this new approach is Bryan Palmer's Canada's 1960s, which challenge this declinist narrative and instead focus on specific legacies such as the student protest movement, gender equality, Quebec Nationalism, and "Red Power" (Indigenous rights movements). ${ }^{41}$ Palmer, a Marxist historian, is concerned with how Canada's collective identity changed in the 1960s as the country moved away from its British roots and "northern and rural values." ${ }^{22}$ The decade's legacy was the rise of class consciousness. Workers, Quebeckers and Indigenous people, and especially students, embraced their own identities based on their respective radicalizing experiences. ${ }^{43}$ However, Palmer is uncertain about whether the legacy of the 1960s was positive, concluding that "Canada exists in the wreckage of a period that brought down with decisive finality what needed dismantling, but that could not build the kind of alternative that was required." ${ }^{44}$ The left nationalists active in the 1970s may have thought otherwise.

\footnotetext{
${ }^{40}$ Cyril Levitt, Children of Privilege: Student Revolt in the Sixties (Toronto: University of Toronto Press, 1984), 185.

${ }^{41}$ Bryan D. Palmer, Canada's 1960s: The Ironies of Identity in a Rebellious Era (Toronto: University of Toronto Press, 2009). Other recent edited collections also address the legacies of the 1960s. See Dimitry Anastakis, ed., the Sixties: Passion, Politics, and Style (Montreal: McGill-Queen's University Press, 2008); M. Athena Palaeologu, ed., The Sixties in Canada: A Turbulent and Creative Decade (Montreal: Black Rose Books, 2009); and Lara Campbell, Dominique Clement, and Gregory S. Kealey, eds., Debating Dissent: Canada and the Sixties (Toronto: University of Toronto Press, 2012).

42 Palmer, Canada's 1960's, 7.

${ }^{43}$ Ibid., 209.

${ }^{44}$ Palmer, Canada's 1960's, 429.
} 
Other historians of the 1960s have also questioned its periodization while discerning its legacies. Stuart Henderson, Ian Milligan, and Jessica Squires outline lasting New Left legacies in their respective studies of the rise of the counterculture in Toronto's Yorkville neighbourhood, the student protest movement, and Vietnam War resisters in Canada. ${ }^{45}$ Unlike Palmer, these historians, concerned with determining the legacy of 1960 s radicalism, subscribe to the idea of the "Long Sixties," which extends the study of the 1960s into the mid-1970s. ${ }^{46}$ Rather than ending their studies of the decade with the seeming defeat of the decade's radicalism in 1968, historians of the "Long Sixties" contend that student protests, the anti-war movement, Quebec nationalism, woman rights and other elements of 1960s radicalism remained prominent in the 1970s. However, left nationalism, also a product of the radicalism of the 1960s, has not received similar attention by historians.

Studies of Canadian nationalisms have concentrated on the 1960s and the rise of New Left and New Nationalist political, intellectual, and cultural circles in and around the Liberal party, while comparatively little has been written specifically on the political fate and intellectual legacy of English Canadian left nationalism in the

\footnotetext{
${ }^{45}$ Stuart Henderson, Making the Scene: Yorkville and Hip Toronto in the 1960s (Toronto: University of Toronto Press, 2011); Ian Milligan, Rebel Youth: 1960s Labour Unrest, Young Workers, and New Leftists in English Canada (Vancouver: UBC Press, 2014); Jessica Squires, Building Sanctuary: The Movement to Support Vietnam War Resisters in Canada, 1965-73 (Vancouver: UBC Press, 2013). 46 There is a major historiographical debate over what constitutes the period of the 1960s, or the Sixties. Some historians such as Andrew Hunt question the periodization and whether the characterization of the Sixties is sound. Andrew Hunt, "'When did the Sixties Happen?' Searching for New Directions," Journal of Social History 33, no. 1 (1999), 147-61. Others such as Joan Sangster propose the concept of the "Long Sixties," ranging from 1965 to 1975. Joan Sangster, "Radical Ruptures: Feminism, Labor and the Left in the Long Sixties in Canada," American Review of Canadian Studies 40, no 1. (2010), 1-21.
} 
1970s. Indeed, while there have been significant advances in studying the history of the 1960s, in contrast, the 1970s have yet to receive a similar treatment by historians. The decade witnessed more than a New Left reckoning, as described by historians of the "Long Sixties." Left nationalism reached its political height during the decade, and the New Canadian Political Economy, the lasting legacy of left nationalism, was founded during this period. This dissertation contributes to the scholarship on the 1970s by examining how left nationalists grappled with the problems of Canadian political economy and Canadian-American relations during a tumultuous period of crisis and transformation.

Most studies of the NDP and its conflict with left nationalists were written by those who took part in the events. A notable example is Desmond Morton, who remains the preeminent historian of the New Democratic Party. Morton was one of the few scholars to have written general histories of the NDP, and as a result his view of the Waffle and left nationalism holds sway in the historiography. ${ }^{47}$ Morton was an avowed opponent of the left nationalist movement, especially the Waffle, which he dismissed as too radical, an imposition of the American New Left, or even communist. Morton was also a supporter of David Lewis who worked for his leadership campaign and was a delegate to the 1971 convention. He also held a prominent position in the Ontario New Democratic Party, having written the party's election platform in the 1971 provincial election.

\footnotetext{
${ }^{47}$ See Morton's, NDP: The Dream of Power (Toronto: A. M. Hakkert 1974, $1^{\text {st }}$ ed.); and the updated and expanded editions, NDP: Social Democracy in Canada (Toronto: Samuel Stevens Hakkert, 1977, $2^{\text {nd }}$ ed.), and The New Democrats, 1961-1986: The Politics of Change (Toronto: Clark Copp Pitman, 1986, $3^{\text {rd }}$ ed.).
} 
For Morton, the Waffle was a distraction which at best offered the party a much-needed internal debate over how to respond to the politics of the 1960s and 1970s. At worst, he thought, it was a damaging detour that cost the NDP support from moderate voters and electoral success. In his NDP: The Dream of Power, published after the Waffle's expulsion from the party in 1972, Morton described the Waffle as little more than "emotionally cathartic for younger, radical academics." 48 The Waffle was an imposition of the American New Left obsessed with American imperialism and "sexual freedom," on Canadian politics. ${ }^{49}$ This ignored Laxer's and other Waffle leaders' stated disillusionment with the New Left and the ways in which the Waffle aimed to move away from American issues such as the Vietnam War.

Many histories of left nationalism, specifically of the Waffle and its conflict with the NDP, were also written by partisans, particularly those active in the movement who wanted to defend its legacy from Morton and other opponents. Notably, a series of retrospectives by former Waffle supporters was published in 1990 in the journal Studies in Political Economy. ${ }^{50}$ The authors agreed that the Waffle contributed positively to the NDP and wider left politics and claimed the NDP became moderate and ineffectual after the Waffle was expelled. Reg Whitaker, a prominent Waffler and left nationalist, claimed that the Waffle's departure from the NDP created an "intellectual vacuum" from which the party never recovered.

\footnotetext{
48 Morton later acknowledged that the Waffle provided the NDP with a much-needed debate over Canadian nationalism. However, during the period under study he was a staunch opponent of the Waffle and left nationalism. Morton, The Dream of Power, 131.

49 Ibid, 135.

50 Studies in Political Economy was founded to disseminate the ideas presented by the New Canadian Political Economists.
} 
Whitaker reported that David Lewis admitted as much, telling him that "when the Waffle left [the NDP], most of the brains left with them."51 Mel Watkins and John Smart claimed that the Waffle directly influenced the economic nationalist policies adopted by the Trudeau Liberal government in the 1971-74 period, such as PetroCanada and the Foreign Investment Review Agency. ${ }^{52}$ These initiatives, to be sure, were supported by New Nationalists in the NDP and the Liberal party, but the Waffle's contribution to the debate cannot be discounted.

Articles by Robert Hackett and John Bullen both situate the Waffle in the historiography of the NDP's struggle to identify itself as either a movement or a party. Hackett described the Waffle as anti-imperialist and a product of the rise of Canadian nationalism and the New Left. ${ }^{53}$ Bullen argued that the Waffle failed because it underestimated the divide between the party's left and moderate wings and focussed too much energy on taking control of the NDP, alienating potential supporters in the process. ${ }^{54}$ Hackett blamed the Waffle's failure on its lack of a Marxist analysis and ideology capable of bringing about social transformation. As a result, the Waffle was unable to overcome the opposition of the NDP establishment and union delegates on the convention floor. Mel Watkins agreed with Hackett's assessment and in hindsight viewed the Waffle as doomed, because it was unable to

\footnotetext{
${ }^{51}$ Reg Whitaker, "Introduction: The 20th Anniversary of the Waffle," Studies in Political Economy 32 (1990), 170.

52 Mel Watkins, "The Waffle and the National Question," Studies in Political Economy 32 (1990), 174. John Smart, "The Waffle's Impact on the New Democratic Party," Studies in Political Economy 32 (1990), 180.

${ }^{53}$ Robert Hackett, "Pie in the Sky: A History of the Ontario Waffle," Canadian Dimension, OctoberNovember 1980, 66.

${ }^{54}$ John Bullen, "The Ontario Waffle and the Struggle for an Independent Socialist Canada," Canadian Historical Review 64, no. 2 (1983), 189-90.
} 
convince the labour movement of the merits of a nationalist agenda..$^{55}$ This dissertation challenges neither Hackett's argument that the labour movement's opposition was a major contribution to the Waffle's failure nor Bullen's claim that the Waffle underestimated the divide between the leftists and moderates in the NDP. It does, however, contest Hackett's assertion that the Waffle lacked a Marxist analysis of Canadian political economy and relations with the United States. Moreover, this dissertation goes beyond the conflict within the NDP, the focus for both Hackett and Bullen, and places the Waffle firmly in the left nationalist movement that was in conflict with New Nationalism.

Recent studies of provincial wings of the Waffle have taken into account its Marxist inclinations. Peter Borch's 2005 MA thesis on the Saskatchewan Waffle differentiates it from its Ontario counterpart. He argues that the Saskatchewan Waffle emerged out of the Committee for a Socialist Movement based in Regina and was made up of expatriate American Marxist intellectuals who aimed to further the cause of socialism in the province. The organization's Marxist ideology led to conflict with the Saskatchewan NDP and its eventual departure. ${ }^{56}$ Another example is Patrick Webber's MA thesis on the Waffle in New Brunswick, which identifies conflict among the Marxists in the group. The New Brunswick Waffle displayed significant Trotskyist orientation, because it was founded by the Fredericton Young Socialists, a branch of the Trotskyist organization the League for Socialist Action.

\footnotetext{
${ }^{55}$ Watkins wrote in 1990 that he believed the opposition of the unions, in alliance with David and Stephen Lewis, was the primary reason for the Waffle's inability to take control of the NDP. Mel Watkins, "The Waffle and the National Question," Studies in Political Economy 32 (1990), 133. ${ }^{56}$ Peter Borch, "The Rise and Decline of the Saskatchewan Waffle, 1966-1973" (M. A. thesis, University of Regina, 2005), 1.
} 
The New Brunswick Waffle was unique in that it was the only group that succeeded in taking control of its provincial NDP. ${ }^{57}$

David Blocker's recent PhD dissertation studies the history of the Canadian New Left and presents the Waffle as a national movement. Blocker argues that the Waffle movement's challenge of the NDP leadership between 1969 to 1972 represented a "dynamic convergence of many of the social movements comprising the New Left." ${ }^{58}$ Blocker is concerned with studying the Waffle's extraparliamentary activity and argues that it was instrumental in keeping alive the political cause of the New Left and Sixties racialism into the $1970 s .{ }^{59}$ However, left nationalism and New Nationalism are not Blocker's subjects of analysis and he does not make the distinction between the two forms of nationalism. Instead, Blocker is interested in situating the Waffle, and its provincial wings, as part of the wider history of the New Left in the "Long Sixties" rather than the political expression of left nationalism in English Canada. Blocker considers the New Left's important legacy in the NDP and presents crucial new research and analysis on the Waffle's various provincial wings and conflict with the NDP. However, he does not study the larger connection between left nationalism and the New Canadian Political Economy. Nor does he examine the writings of prominent left nationalists on the subject of American dependency or resource exportation, which are important

\footnotetext{
${ }^{57}$ Patrick Webber, "For A Socialist New Brunswick: The New Brunswick Waffle, 1967-1972" (M. A. thesis, University of New Brunswick, 2008).

${ }^{58}$ David G. Blocker, "To Waffle to the Left: The Waffle, the New Democratic Party, and Canada's New Left During the Long Sixties" (PhD diss., Western University, 2019), 1.

${ }^{59}$ Ibid., 7.
} 
subjects in discerning the characteristics and legacies of English Canadian left nationalism, anti-imperialism, and neo-Marxism.

This dissertation goes beyond studying the Waffle's relationship with the New Left. It considers the debates over left nationalism's significance and its legacy both within and outside the NDP. The research focussed on a corpus and canon of English Canadian left nationalist writings, supplemented by work in archival collections. Many of these left nationalists including Gordon Laxer, Daniel Drache, and Philip Resnick, who consistently identified their academic and political pursuits as Marxist. Mel Watkins and James Laxer also wrote academic texts but were conscious of their positions of leadership in the left nationalist movement and mainly sought to disseminate their ideas beyond an academic setting. They aimed to justify their ideas to the public through books written for a general audience and articles in outlets sympathetic to their cause, such as Canadian Dimension. This periodical served as the popular organ of the movement, with articles that frequently criticized the Liberal government, the NDP leadership, Canada's capitalist system, and the country's relations with the United States

Academics associated with the New Canadian Political Economy, such as Leo Panitch, Wallace Clement, Paul Craven and other neo-Marxists, were concerned less with labelling themselves as left nationalists or being caught up in the antiimperialist and populist politics of the Waffle movement. Their primary concern was interrogating the Canadian state, which they viewed as hegemonically capitalist and ultimately responsible for the country's dependence on the United States. These 
academics shared a goal of transforming Canada into a socialist political economy free from American dependency.

\section{Chapter Outline}

The first chapter is an investigation into the political manifestations of left nationalism, the most significant of which was the Waffle movement. The chapter argues that left nationalism emerged as a distinctive form of economic nationalism that was in contention with the moderate agenda of the NDP. The Waffle forced the NDP to recognize the need for a clear position on economic nationalism and Canada's relationship with the United States. Opposition to the Waffle Manifesto from the NDP establishment at the party's 1969 policy convention demonstrated the struggle between democratic socialism and the moderate social democratic wing of the English Canadian left.

The second chapter studies James Laxer's Waffle-endorsed campaign for the leadership of the NDP, and the manner in which the Waffle sought to advance a left nationalist agenda at the 1971 NDP leadership convention. The NDP's eventual rejection of the Waffle's agenda and the decision to pursue a policy of political moderation in line with the New Nationalist agenda proved that the NDP was not a party that subscribed to left nationalism as the core of its political philosophy. The Waffle's expulsion from the party in 1973 led to a period of introspection among left nationalists, many of whom questioned the usefulness of combining nationalism with democratic socialist politics. 
The third chapter moves beyond the Waffle and studies how English Canadian left nationalists confronted the problem of dependency in the context of American decline. According to left nationalists, the 1971 Nixon Shock represented the end of Canada's privileged status in the American Empire, with dire consequences for Canada. While left and New Nationalists shared a concern over American dependency and decline, this chapter demonstrates the differences between the groups. Left nationalists insisted that only a revolutionary change in the Canadian political economy and relationship with the United States would liberate Canada from the American empire. In contrast, New Nationalists wanted to salvage capitalism through reform, regulation, and increasing Canadian ownership. However, they were also worried about Americanization, and on this issue, the left and New Nationalist agendas were incompatible.

The fourth chapter maintains the theme of the contrasting perspectives of English Canadian nationalists, in this case with reference to the politics of energy exportation to the United States. Left nationalists used the energy crises of the early 1970s and resulting controversies surrounding a proposed continental resource deal and the Mackenzie Valley pipeline as an opportunity to advance their political causes. By 1973 the most pressing issues for both left and New Nationalists was American ownership of the resource sector and Ottawa's willingness to allow the widespread sale of resources to American manufacturers with little concern for long term economic and environmental consequences. Nationalists agreed that Canada had to diversity its trade in energy resources and counter American dominance of the sector, but they disagreed over how to address the issue. The chapter also charts 
the rise of ecological independence, the concern that Canada must maintain sovereignty over its finite natural resources such as oil, gas, and water. On this issue, all nationalists were of the same opinion. The chapter maintains that ecological independence was one of the major unifying impulses in the wider English Canada nationalist movement.

The fifth chapter asserts that neo-Marxism formed a core tenet of left nationalism. It studies the circumstances and characteristics of the introduction of neo-Marxism into the academic community by examining texts written by the New Canadian Political Economists, who sought to bring a globally ascendant neoMarxian scholarship to Canada. Many New Canadian Political Economists were neoMarxists who were directly influenced by the politics of left nationalism. They sought to study the issue of Canada's semi-peripheral dependent status in order better to articulate a political agenda that would enable independence through socialism. Their introduction of neo-Marxism into the Canadian academy represents a lasting legacy of left nationalism in English Canada. 


\section{Chapter 1: The New Democratic Party and the Rise of the Waffle, 1968-1969}

In the words of CBC correspondent Ron Collister, the November 1969 federal New Democratic Party (NDP) convention witnessed a "party trying to cure its political schizophrenia." Delegates were forced to choose between "the [Mel] Watkins way of an independent socialist Canada," and the "David Lewis way that declared Canadians were not anti-Americans." Mel Watkins outlined the English Canadian left nationalist agenda: "if we are to take power, we must know who we're taking it from. The western world is dominated by a small number of large corporations, mostly American-based. These corporations, and the American government in which they are closely related are the new industrial state, the essence of the military industrial complex." 1 This chapter will demonstrate how left nationalism emerged out of a political climate characterized by a growing concern with Canada's relationship with the United States and increasing support for economic nationalism. As demonstrated by the Watkins Report and the NDP policy convention, left nationalism was by 1969 a distinct strand of economic nationalist thought in Canada in conflict with the New Nationalist agenda.

The 1968 federal election was a disappointing one for the NDP. The party failed to capitalize on the social change that had swept Canada in the preceding years and was out-maneuvered on the left by Liberal leader Pierre Trudeau. The NDP, dominated by the CCF old guard of leader Tommy Douglas and deputy leader

\footnotetext{
${ }^{1}$ CBC Archives, "Manifesto for an Independent Socialist Canada Splits the NDP in 1969," video, https://www.cbc.ca/archivs/entry/manifesto-for-an-independent-socialist-canada-splits-ndp-in1969.
} 
David Lewis, was wary of embracing leftist policies that would alienate the middle class voters it was courting. ${ }^{2}$ Still, despite the NDP leadership's skepticism about the American New Left, there was unease at the direction the United States was taking in global politics, especially in light of the escalation of the Vietnam War and racial violence in American cities. The NDP did attempt to differentiate itself from the Liberals by expressing support for economic nationalist measures. The Liberals were returned to power in 1968 with a majority government. Undeterred, a new generation of NDP activists, made up mostly of youth and academics, sought to shape the party in their left nationalist image.

The rise of left nationalism as a major political force in Canadian politics began with the events that led to the publication of the Manifesto for an Independent Socialist Canada, later known as the Waffle Manifesto. It represented a new strand of thought in English Canadian nationalism. Where the New Nationalists were concerned with foreign direct investment and its effects on Canadian capitalist enterprise, left nationalists argued that a socialist agenda was the only means of preserving economic independence. As the manifesto declared:

Canada's survival as a cultural and economic entity is threatened; Canadian capitalists are too wrapped up in the continental economy to be expected to lead a movement for greater independence; socialism and independence are therefore interdependent: Canadian independence is not now possible without socialism; socialism is not possible without independence. ${ }^{3}$

\footnotetext{
${ }^{2}$ Cy Gonick, "The Year of the Waffle!" Canadian Dimension, December-January 1969-1970, 5.

3 "The Manifesto for an Independent Socialist Canada," (1969) is printed in Michael S. Cross, ed., The Decline and Fall of a Good Idea: CCF-NDP Manifestos, 1932-1969 (Toronto: New Hogtown Press, 1974), 43-5. Hereafter: "Manifesto for an Independent Socialist Canada."
} 
Left nationalists did not aim to foster, bolster, or defend Canadian capitalism or increase domestic corporate ownership of the resource or manufacturing sectors. They sought to replace capitalism with socialism, first through the public ownership of the resource sector, followed by the full nationalization of all key sectors of the Canadian economy. In short, the lack of independence was the problem, and socialism was the solution.

The Watkins Report and "Getting to Democratic Socialism"

The NDP came under attack from left nationalists disappointed by the party's agenda and electoral performance. As an example of the criticism the NDP faced from those associated with left nationalism, vocal left nationalist Stanley Gray argued the NDP "fail[ed] to create a popular movement for a democratic and socialist Canada" and did not take advantage of the energy of youth protest movements. Gray believed the NDP was focussed too much on parliamentary politics and gradual social reform, doubting if the party was a true leftist force. ${ }^{4}$ Waffle co-founders Gerald Caplan and James Laxer went further and claimed the NDP had been "born at the end of a long ideological retreat on the part of its successor, the CCF." ${ }^{5}$ In justifying their left nationalist agenda, Laxer and Caplan contended that the NDP was founded as a part of moderation that deliberately rejected the radical agenda of the CCF.

\footnotetext{
${ }^{4}$ Stanley Gray, "New Left, Old Left," Canadian Dimension, November-December 1965, 11-13. ${ }^{5}$ James Laxer and Gerald Caplan, "Perspectives on un-American Traditions in Canada," in Close the 49th Parallel Etc.: The Americanization of Canada, ed. Ian Lumsden (Toronto: University of Toronto Press, 1970), 315.
} 
New Left and left nationalist criticism of the NDP was regularly expressed in the pages of Canadian Dimension. Cy Gonick, the Manitoba MLA, editor of the Canadian Dimension, and later co-founder of the Waffle, was a prominent New Leftist and critic of Canadian economic and foreign policy. He observed that prior to the 1969 convention the NDP seemed to be drifting towards moderation. Looking back on the past two decades of the CCF/NDP, Gonick claimed,

it is the custom of social democrats when attacked from the right to veer to the right; then attacked from the left, to veer to the left. Until recently, all the pressure on the NDP has come from forces that are clearly conservatizing: electoral politics, the daily press, the trade unions. The result has been a steady drift of the party towards moderation and mild reform. ${ }^{6}$

James Harding, another prominent New Leftist doubted that the NDP was even relevant, writing in Canadian Dimension that "the present rationale of the NDP stands in contrast to the position of the New Left ... [as] ... our present political institutions are not capable of ensuring the our degree of democracy will survive or participation in decisions occur."7 The NDP, not even a decade old, was at risk of becoming discredited as a relic of what Watkins called the Old Left.

In February 1968, in the midst of rising nationalist fervour, and just before the election call, the Task Force on Government and Foreign Ownership and the Structure of Canadian Investment released its report. ${ }^{8}$ Despite explicitly stating that it had not been endorsed by the federal government, the Report caused a media

\footnotetext{
${ }^{6}$ Gonick also speculated that "no doubt this direction was greatly influenced by the mood of the 1950s and 1960s, the formative years of the NDP, a period when North American capitalism seemed so immensely successful that fundamental opposition to it lacked political credibility." Cy Gonick, "The Year of the Waffle!" 5.

7 James Harding, "The NDP, the Regina Manifesto and the New Left," Canadian Dimension, NovemberDecember 1966, 19.

${ }^{8}$ Mel Watkins et al, Foreign Ownership and the Structure of Canadian Industry: Report of the Task Force on the Structure of Canadian Industry (Ottawa: Queen's Printer, 1968).
} 
sensation. ${ }^{9}$ Dubbed the Watkins Report after the task force's head, Mel Watkins, it declared that the extent of foreign control of Canadian industry was unique among the industrialized nations of the world. ${ }^{10}$ The Report did not recommend any radical measures to curtail foreign investment in Canada, opting instead to rationalize its recommendations with current government policy. ${ }^{11}$ It recommended tariff reductions and the creation of a Canadian Development Corporation to provide much needed capital to Canadian-owned companies. Of utmost concern to the task force's members was the issue of extraterritoriality and they recommended the federal government pass legislation to prevent foreign laws such as the American Trading with the Enemy Act from being applied to foreign-owned companies operating in Canada. ${ }^{12}$ Looking back at his work on the task force, Watkins expressed frustration with the inability or unwillingness of the "mandarins" to address the issue of extraterritoriality and what he saw as Canada's resultant complicity in the American war in Vietnam. Watkins recalled:

\footnotetext{
${ }^{9}$ The Toronto Telegram and Winnipeg Free Press maintained their opposition to restricting foreign investment, while Toronto Star praised the report. Stephen Azzi, Walter Gordon and the Rise of Canadian Nationalism (Montreal: McGill-Queen's University Press, 1999), 168.

10 Other prominent participants of the task force included Abraham Rotstein, A. E. Safarian of the University of Toronto, and Stephen Hymer of Yale University. Azzi, Walter Gordon, 158-59.

${ }_{11}$ Watkins admitted that he censored himself when writing the Report, avoiding terms such as socialism and imperialism. Mel Watkins, "Learning to Move Left," This Magazine is About Schools (Spring 1972), 76.

12 On this issue of extra-territoriality Watkins wrote, "the most serious cost to Canada of foreignownership and control results from the tendency of the U.S. government to regard American-owned subsidiaries as subject to American law and policy with respect to laws on freedom of export, U. S. antitrust law and policy, and balance of payments policy." This "intrusion" of American law and policy into Canada "implied that the American-based multinational corporation is not multinational, but American." Mel Watkins, "The Watkins Report," in Gordon to Watkins to You: A Documentary: The Battle for Control of Our Economy, ed. Dave Godfrey and Mel Watkins (Toronto: New Press, 1970), 723.
} 
it wasn't simply the frustration with Vietnam, and of the American presence so blatant in our society. It was the whole damn thing in Ottawa all over again - listening to the mandarins talk, listening to them agree with everything you say: 'yes there are too many American firms; yes, it's not right to burn babies' - but you're never allowed to do anything, to change anything... When I get thrown into that kind of political situation, I inevitably get radicalized. ${ }^{13}$

In 1968, with the Vietnam War intensifying, Watkins argued that while Canada had not been an active participant, the government was complicit as the munitions industry profited from the war, and Ottawa had not openly confronted the United States, or proposed solutions to resolve the conflict in Vietnam. ${ }^{14}$ The link between Vietnam and the Watkins Report was evident in the media. Historian Stephen Azzi noted that media coverage often contextualized the Watkins Report alongside articles and photographs of the war in Vietnam and police response to anti-war protests in the United states. ${ }^{15}$

NDP leader Tommy Douglas indicated that he wanted to present the NDP as the party of a moderate economic nationalism. The NDP was highly receptive to the findings of the Watkins Report. During the 1968 federal election campaign Douglas promised to implement its findings, such as legislation to deal with extraterritoriality and a Canada Development Corporation, and he criticized the Liberals for doing little to reverse continentalism. Douglas went as far as inviting Watkins to campaign for the NDP, but Watkins declined. ${ }^{16}$ The NDP's economic nationalist agenda was premised on the moderate economic nationalist notion of

\footnotetext{
13 Watkins, "The Watkins Report," 61.

${ }^{14}$ Alistair Dow, "Douglas: Buy Canada Back or Lose Sovereignty," Toronto Star, June 24, 1968.

${ }^{15}$ Azzi, Walter Gordon, 162-63.

16 Dow, "Douglas: Buy Canada Back or Lose Sovereignty."
} 
buying-back the Canadian economy. This program was more aligned to that of the New Nationalists than the agenda of the left nationalists.

Watkins was becoming receptive to left nationalism, and he later acknowledged that the process of writing and defending the report had "push[ed] me towards socialism." In his rejection of support for moderate economic nationalist measures, he explained: "it seemed clear to me that only through substantial nationalization could Canadians regain control of their economy." As a result, he did not endorse the NDP agenda in 1968, despite the fact that the party presented the most economic nationalist agenda. Watkins, an early sympathizer with the New Left, claimed that he was uncertain of the NDP's policies, describing them as part of the Old Left. Watkins was more inclined to what he called the "New Left version of socialism" based on "democratic decision making."17 Reflecting on his embrace of socialism, Watkins explained that working on the Report,

It seemed clear ... that only through substantial nationalization could Canadians regain control of their economy. It also became obvious ... that the people interested in nationalization would not be the present business elite who in many cases were doing very well as branch plant managers. A powerful transition towards socialism would mean that one had to appeal to the ordinary working people who had most to gain if Canada became economically independent. ${ }^{18}$

Watkins reluctance to embrace the NDP's Old Left agenda, his work on the Watkins Report, and the Liberals' hostility or indifference to the findings of the Report, led him to an increasingly radical political outlook. He embraced left nationalism as a program for addressing his concerns about American dependency.

${ }^{17}$ Watkins, "Learning to Move Left," 82.

${ }^{18}$ Ibid. 
Watkins' support for "New Left socialism" was an endorsement of the democratic socialism of the English Canadian New Left and the left nationalist movement. In Gordon to Watkins to You, Watkins reflected on "getting to democratic socialism" and articulated the socialist agenda of left nationalism. Watkins recalled that his experience as a student in the United States was also "radicalizing." "I went to the United States [as a student] a lukewarm Canadian nationalist and I was turned into an American left-wing liberal."19 By the end of the 1960s, after growing disdain for the Vietnam War and frustration at the moderate agenda of the Liberals and NDP, Watkins was a committed democratic socialist.

Watkins defined his socialist agenda as working for "the redistribution of power to ordinary people and because there isn't much power left in Canada anymore, it means getting back power the better to distribute it."20 "People" and "power" were all-encompassing terms. "People" meant Canadians who did not benefit from American foreign investment and corporate ownership. "Power" referred to the control and influence of the American-based multinational corporations and the technocratic elites who enabled them. For Watkins, to be a left nationalist meant to be a democratic socialist and an anti-imperialist. These beliefs contradicted those of the NDP.

\footnotetext{
${ }^{19}$ Watkins remembered that he had grown deeply disillusioned with the war by 1963. Mel Watkins, "Getting to Democratic Socialism 1: Mel Watkins: Points of Departure," in Gordon to Watkins to You: A Documentary: The Battle for Control of Our Economy, ed. Dave Godfrey and Mel Watkins (Toronto: New Press, 1970), 5-6.

${ }^{20}$ Mel Watkins, "Getting to Democratic Socialism 4: Here and Now," in Gordon to Watkins to You: A Documentary: The Battle for Control of Our Economy, ed. Dave Godfrey and Mel Watkins (Toronto: New Press, 1970), 136.
} 
Anxiety over Canadian-American Relations

Another dimension of Watkins' left nationalism was his critical view of Canadian-American relations. Watkins' musings about Canada's integration into the American War machine led him to criticize the state of Canadian-American relations based on Marxist verbiage of dependency and anti-imperialism. Watkins argued that Canada's relations with the United States reflected the branch plant economy. He claimed that the Canadian foreign policy establishment preferred quiet diplomacy aimed at minimizing any tensions within the "imperial system," along with a "mercantilist strategy" that looked to a special status within the empire. ${ }^{21}$ Watkins views reflected the common left nationalist critique of Canada's relations with the United States. Canada presented itself as a reliable ally to the hegemonic power that it depended on for its prosperity and arguably its very existence.

Watkins' view of Canadian-American relations and the North American political economy reflected the politics of the late 1960s, which was characterized by a growing nationalist sentiment in English Canada. Nationalists hoped that Canada would finally be presented with a strategy for addressing the problem of American dependency. However, left nationalists believed that Canadian liberalism was unwilling or unable to pursue a foreign policy independent from the United States.

${ }^{21}$ Mel Watkins, "Getting to Democratic Socialism 3: Grassroots and the Branch-Plant Mind," in Gordon to Watkins to You: A Documentary: The Battle for Control of Our Economy, ed. Dave Godfrey and Mel Watkins (Toronto: New Press, 1970), 86-7. 
During the 1960s the Canadian left had grappled with the issue of Canada's participation in American-led military alliances. Of particular concern was whether Canada could maintain its diplomatic standing and influence as a middle power if it pursued a policy of non-alignment in the Cold War, also known as neutralism. ${ }^{22}$ In March 1966 Canadian Dimension published a supplement on Canadian foreign policy that discussed challenges and propose leftist alternatives. While no plan of action was identified, the merits of neutralism were debated. This supplement served as a preview of how left nationalists would later approach the issue of Canadian alignment with the United States as concern with Canada's dependence on the United States intensified in the coming years.

John Warnock's neutralist sentiment was indicative of the emerging left nationalist movement. Warnock was a Marxist who contributed widely to the left nationalist literature. In his contribution to the Canadian Dimension supplement Warnock claimed that Canada's continued participation in the North Atlantic Treaty Organization (NATO) alliance was a source of continued embarrassment for Canada. Warnock dismissed the claim that participation in NATO was essential to prevent Canada from falling completely into a bilateral Canada-United States defence system and consequently "total subordination" to the United States. ${ }^{23}$ The Canadian government was not concerned by that possibility because there was no serious attempt to move away from reliance on the Americans for defence. Expressing the

\footnotetext{
22 In this context "non-alignment" was also referred to as "neutralism" or "neutrality," all of which were terms used to describe a policy of remaining neutral in the Cold War by not participating in military alliances led by the United States or the Soviet Union.

${ }^{23}$ John W. Warnock, "Canada and the Alliance System," Canadian Dimension, March-April 1966, 39.
} 
fears of American dependency and support for neutralism, Warnock stated that Canada was

... already in a sort of commonwealth relationship [with the United States] similar to that of Puerto Rico... If NATO breaks up, I would not be happy living in a country which decides to remain closely aligned to the United States. On the other hand, I would not want to live in a country which gives its support to an Atlantic Community [NATO] based on white supremacy and coupled with a desire to preserve an increasingly affluent society at the expense of keeping the underdeveloped world in a state of quasi-slavery. ${ }^{24}$

For Warnock, membership in NATO and Canada's Cold War alignment with the United States meant that Canada was complicit in American imperialism. He contended that Canada risked becoming fully absorbed into the American empire and thus a perpetrator of the dependency and exploitation of the underdeveloped world. Warnock believed that, for Canada, the only alternative was non-alignment and withdrawal from NATO and NORAD (and indeed all military alliances); doing so, he claimed, would allow Canada to play an active part in international politics. ${ }^{25}$

The NDP was not willing to maintain the status quo in Canadian defence and foreign policy and advocated for Canadian neutrality in the Cold War, but at the same greater activism on the world stage. In 1969 the party was committed to neutralism, arguing that the United States, like the Soviet Union, had at times threatened global peace and stability. Indicative of the NDP's stance on the issue, Member of Parliament Ed Broadbent presented to the House of Commons a coherent vision of Canada as a robust middle power acting independently of the United States. Broadbent envisioned Canada maintaining its status as an influential

24 Warnock, "Canada and the Alliance System," 39.

25 Ibid., 39-40. 
middle power through Cold War neutrality. Broadbent claimed that Canada's continued membership in NATO was acting as a hindrance, constraining the country's ability to fulfill what he believed should be its main foreign policy goals of "preserving international peace, assisting the developing world, fostering and protecting democratic societies, and maintaining national sovereignty."26 In addition to being obsolete, NATO was portrayed as a tool for keeping the United States' allies in line. This was his party's viewpoint.

Broadbent's, and the NDP's, position on NATO was that Canada's continued membership in the alliance was “limiting Canada's independence and making Ottawa complicit in the transgressions of its members." Broadbent argued that "Canada as a non-member of NATO would be free at the United Nations to criticize equally the two dominant powers of the World [the United States and the Soviet Union]."27 Unlike Warnock, Broadbent advocated neutrality, but not as a means of isolating Canada from the world's problems, a futile endeavour in any case because of Canada's geographic position between the two superpowers. Idealism and lofty ambition aside, Broadbent's point was clear. There could be no true independence for Canada if it did not pursue neutrality and free itself from the constraints of the Cold War American military alliance. Broadbent's optimism about an independent Canadian foreign policy reflected the spirit within his party as activists sought to present a new program for a new decade, hoping that it would consist of a combination of socialism and independence.

\footnotetext{
${ }^{26}$ Ed Broadbent, "House of Commons Speech on NATO," April 24, 1969, House of Commons Debates, 7942-43

27 Ibid., 7943.
} 
The growing apprehension with Canada's relationship with the United States was indicated by neutralist sentiment in the Canadian left and concern with American dependency. This contributed to a favourable climate for the dissemination of left nationalism in English Canada. Alongside the rise of nationalism was a concern with the long-term prospects of the NDP and the centreleft political program it represented. Left nationalists, many of whom were already active in NDP circles, seized the opportunity to shape the party into a vehicle for expressing their left nationalism.

\section{The Waffle Manifesto}

Watkins found an ally for his left nationalist agenda in James Laxer, who at the time was a PhD student at Queen's University. Laxer was influenced by his father Robert, a prominent Canadian communist, and by the student-led politics of the American and international New Left, particularly the Student Union for Peace Action. ${ }^{28}$ Laxer, however, later grew critical of the American New Left's relationship with Canada, arguing that the Canadian New Left became preoccupied with American concerns, such as the Vietnam War, civil rights, and the draft, and owed much of its style and ideology to the United States. Laxer believed these were legitimate issues that needed to be confronted by a global network of New Left activists, but they consumed the attention of Canadian activists, preventing them

\footnotetext{
${ }^{28}$ Laxer recollected on his upbringing and his father's communism in his memoir Red Diaper Baby: A
} Boyhood in the Age of McCarthyism (Toronto: House of Anansi Press, 2004). 
from developing an agenda relevant to addressing specific Canadian issues. ${ }^{29}$ For Laxer, the real "enemy" was "American imperialism," and the Canadian left, with its preoccupation with American issues, was unable to grasp the extent of Canada's perilous situation caused by its relationship with the United States. ${ }^{30}$

Laxer was also highly critical of the NDP's performance during its first decade as a party, arguing that it failed to respond to, or capitalize on, the social and political upheaval of the 1960s. He blamed the moderating forces within the NDP, such as the party leadership's insistence on winning elections by appealing to a middle-class electorate, and the American-based unions that steered the party away from socialism. ${ }^{31}$ The party nevertheless retained a potential to become socialist because of its support base made up of workers, farmers, students, and intellectuals. ${ }^{32}$ Launching a new political party was impractical. Instead, Laxer believed that the best way to bring about the radical change Canada needed was to convince the NDP to embrace a socialist agenda. It was these beliefs that influenced Laxer, Watkins, and other members of the NDP, to launch the "Manifesto for an Independent Socialist Canada."

In April 1969 after a year spent promoting the Watkins Report, Watkins was invited by Gerald Caplan, a professor at the Ontario Institute for Studies in

\footnotetext{
${ }^{29}$ James Laxer, "The Americanization of the Canadian Student Movement," in Close the 49th Parallel etc.: The Americanization of Canada, ed. Ian Lumsden (Toronto, University of Toronto Press, 1970), 276.

${ }^{30}$ John Bullen, "The Ontario Waffle and the Struggle for an Independent and Socialist Canada: Conflict within the NDP," Canadian Historical Review 83, no. 2 (June 1983), 193.

31 James Laxer and Arthur Pape, "Youth and Canadian Politics," in Canada and Radical Social Change, ed. Dimitrios Roussopoulos (Montreal: Black Rose Books, 1973), 49.

32 James Laxer and Gerald Caplan, "Perspectives on un-American Traditions in Canada," in Close the 49th Parallel, ed. Ian Lumsden (Toronto: University of Toronto Press), 314-15.
} 
Education, to attend a meeting on the future of the NDP and the Canadian New Left movement. As documented by David Blocker in his PhD dissertation, others who were invited included James Laxer, Krista Maeots, John and Patricia Smart, Giles Endicott, and Ed Broadbent. Attendees were described by Caplan as like-minded friends and acquaintances who felt "significantly to the left of the NDP, but not happy to simply embrace all of the jargon and tactics of the New Left." 33 According to Blocker, all those in attendance shared Watkins' and Laxer's concerns about the trajectory of the NDP and the problem of American dependency. ${ }^{34}$ Over the next few months, Watkins, Laxer, and Caplan and their supporters debated how to address the issue of Canadian independence and express an agenda of left nationalism. The result of their endeavours was the "Manifesto for an Independent Socialist Canada."35

The "Manifesto for an Independent Socialist Canada," latter dubbed the Waffle Manifesto, ${ }^{36}$ directly reflected the concerns of left nationalists and was publicly revealed in September 1969. The manifesto claimed to espouse an agenda of democratic socialism, with its primary objective the building of "an independent socialist Canada." Reflecting the views of Watkins and Laxer, the manifesto declared that "the major threat to Canadian survival today is American control of the

\footnotetext{
33 David Blocker, "To Waffle to the Left: The Waffle, the New Democratic Party, and Canada's New Left during the Long Sixties," (PhD diss., Western University, 2019), 132.

34 Ibid., 135.

35 Blocker provides a detailed account of the internal debates between the Waffle's founders over the writing on the manifesto. Ibid., 134-40.

${ }^{36}$ The reason for the name "Waffle" is still the subject of debate. Desmond Morton attributed it to a comment by Ed Broadbent about "waffling to the left or right." In September 1969 the Globe and Mail used the Waffle Manifesto as the title of their editorial on the subject. The group wanted the NDP to waffle to the left and supporters readily took up the moniker. Ibid., 139.
} 
Canadian economy. The major issue of our time is not national unity, but national survival, and the fundamental threat is external, not internal." Echoing Watkins's concerns, the manifesto asserted that foreign investment "reduced Canada to a resource base and consumer market ... of an empire which was characterized by militarism abroad and racism at home." To remedy this situation, the manifesto argued that socialism must be implemented, defining it as "national planning of investment and the public ownership of the means of production in the interests of the Canadian people as a whole." 37

The Waffle Manifesto concluded with a hopeful view of the NDP, arguing that the party was the organization best suited to bringing the vision of an independent socialist Canada to fruition. The NDP was effectively given an ultimatum: demonstrate a willingness to welcome left nationalists and socialists and become a truly radical force in Canadian politics or fail as a political party. In the summer of 1969, the Waffle Manifesto was circulated among a small group of NDP members. Leading up to the convention, ninety-four members, including Nova Scotia NDP leader Jeremy Ackerman, British Columbia MLAs Dave Barrett, Eileen Dailly, Gordon Dowding, Jim Lorimer, and Alex MacDonald, and Cy Gonick endorsed the manifesto. ${ }^{38}$ However, several early supporters of the Waffle such as Ed Broadbent and philosopher Charles Taylor turned away, believing the manifesto in its final form was too extreme. Nevertheless, there was considerable support in the party demonstrated by the New Democratic Youth Wing (NDY) and twenty-four riding

\footnotetext{
37 "The Manifesto for an Independent Socialist Canada."

38 Desmond Morton, The New Democrats: 1961-1986, the Politics of Change (Toronto: Copp, Clark, Pitman, 1986, $3^{\text {rd }}$ ed.), 93-4.
} 
associations pledging their support. ${ }^{39}$ By the time of its public launch in September it was clear that the Waffle was not a small fringe movement.

Socialism Canada '70s: Preparations for the 1969 NDP Policy Convention

In October 1969, with the party still reeling from its failure to win additional seats at the previous year's federal election and the Waffle stepping up its campaign for left nationalism, NDP delegates convened in Winnipeg for a policy convention. ${ }^{40}$ Dubbed “Socialism '70," the convention was billed as an opportunity to engage new ideas that would win over wavering centre-left voters who had decisively shifted to the Liberals in the 1968 election. In the months leading up to the convention, the party executive circulated several policy discussion papers, later published as Socialism Canada '70s. ${ }^{41}$ These position papers were written by Members of Parliament, economists, and union leaders, with topics ranging from agricultural policy to a universal basic income and technological development. An overarching theme was a debate between moderate and left nationalists over the issue of American dependency.

Waterloo, Ontario Member of Parliament Max Saltsman did not hide his support of economic nationalism and support for the recommendations of the Watkins Report in his contribution to Socialism Canada '70s. In the opening of his

\footnotetext{
${ }^{39}$ John Bullen, "The Ontario Waffle and the Struggle for an Independent Socialist Canada: Conflict Within the NDP," Canadian Historical Review 64, no. 2 (June 1983), 194.

${ }^{40}$ At the 1968 federal election the NDP won twenty-two seats, the same number as the previous 1965 election, and suffered a decline in the popular vote. The Liberals won one hundred-fifty-four and the Progressive Conservatives seventy-two.

${ }^{41}$ Debates of what sort of economic nationalism to adopt were prevent in the papers written by Max Saltsman, Ed Finn, and Mel Watkins, titled "Towards a Responsible Development Corporation;" "Nationalism and the NDP;" and "Economic Independence and Socialism."
} 
paper "Towards a Responsible Development Corporation," Saltsman declared that the Canadian voter was restless over Canada's economic and social dependence on the United States. Echoing the sentiment of emergent left nationalism, he argued that Canada had become

little more than a client state, [with] our foreign outlook dictated by the need to please our U.S. customers, our independence captive to fear of economic retaliation, and our values packaged by Madison Avenue. Unless we can overcome these constraints, even limited national and personal independence is beyond our grasp. ${ }^{42}$

According to Saltsman, Canada was in the grip of American corporate control, economically and culturally, for which he blamed the Liberal government and its pursuit of "continentalism." 43 For Saltsman, the problem was not the United States, but the domination of Canada by foreign corporate investment, regardless of nationality. The real problem, declared Saltsman, was "the international corporation and its sheer dominating size," and he argued that economic nationalism had the potential to shield Canada from this domination. ${ }^{4}$

In contrast, Ed Finn proposed bolder action and wanted the NDP to fully commit to an agenda of left nationalism. Finn was the former leader of the Newfoundland NDP and in 1969 was a trade union leader. His paper, "Nationalism and the NDP," placed him in the emergent left nationalist camp of the party. He defined New Nationalism as little more than the "centennial-Expo local boosterism." ${ }^{45}$ Unlike Saltsman, Finn tied his nationalist agenda to anti-imperialism.

\footnotetext{
42 Max Saltsman, "Towards a Responsible Development Corporation," 1-2, in NDP Policy Papers, CCF/NDP Fonds MG28 IV-I, vol. 398, file 3.

${ }^{43}$ Saltsman, "Towards a Responsible Development Corporation," 2.

${ }^{44}$ Ibid., 4.

${ }^{45}$ A reference to Canada's Centennial in 1967 and Expo '67 festivities in Montreal and around the country.
} 
He used anti-imperialist rhetoric, describing left nationalism as premised on "a wish to prevent Canada from becoming an American colony." His agenda was also based on a desire to preserve a "Canadian way of life from American economic and cultural influence to build a society that is better than that of the United States." 46 What exactly this distinct Canadian way of life entailed was never explained, but it was assumed that an independent Canada would be socialist.

Finn was not worried about the political viability of left nationalism. He presented his agenda as a means of countering the dominance of the Liberal and Progressive Conservatives in Canadian political life. He believed that the "active promotion of the American takeover of the Canadian economy" by the Liberals and Progressive Conservatives presented the NDP with an opportunity to stand out and regain popularity with the electorate. ${ }^{47}$ Reflecting the opinion of left nationalists, Finn equated opposition to socialism with favouring "American penetration into Canada." The Liberals and Conservatives were not worried about it because it "violated none of their principles [and] ... they have no vision of a future Canada which can be distinguished from present American society. The values and attitudes which American corporations bring with them coincide with the basic values and attitudes of the Liberal and Tory parties." Finn was of the firm belief that, if the forces of continentalism were to be countered, a political party needed to wholeheartedly endorse left nationalism. In contrast to the Liberals and Progressive

${ }^{46}$ Ed Finn, "Nationalism and the NDP," in NDP Policy Papers, 1, CCF/NDP Fonds MG28 IV-I, vol. 398, file 3.

${ }^{47}$ Ibid., 1-2. 
Conservatives, Finn forcefully declared that the "chief prerequisite for the fulfilment of the NDP's policies is the preservation of an independent nation." 48

Nationalism, according to Finn, was compatible with a leftist agenda. Despite the concerns about nationalism held by many on the left, Finn believed it was important to advance a "positive" nationalist agenda to facilitate a New Left political program of liberating Canada from the American empire. He pointed out there was a major difference between the nationalism espoused by a large country seeking to expand its hegemonic power (the United States) and that of a small nation preserving its independence (Canada). ${ }^{49}$ Finn was hopeful that an NDP with a program based on left nationalism would give the party a means of clearly differentiating itself from the other parties and offering voters a clear alternative. Unfortunately for Finn, there was little consensus over how this nationalist program would be designed and implemented.

Watkins accepted the invitation to contribute to Socialism Canada '70s, which he used as an opportunity to advance his left nationalist agenda. Watkins' policy paper for the fall NDP convention was an articulation of the policies he hoped that the party, as the only potential force for left nationalism in Canada, would adopt. It was up to party delegates to decide if they wanted to transform the NDP into a vehicle for the socialist policies Watkins prescribed to preserve Canada's economic independence. Of all the papers submitted to the NDP, Watkins' “Economic Independence and Socialism" was the clearest representation of the ideas of the

${ }^{48}$ Finn, "Nationalism and the NDP," 2.

${ }^{49}$ Ibid., 4. 
emerging left nationalist camp. He believed socialism and economic independence were synonymous: "we need socialism so that we can have independence; we need independence so we can have socialism." 50

Watkins declared that the link between socialism and the movement for economic independence was not a marriage of convenience. Instead, it was "necessary and desirable ... [t]here can be no real independence without socialism, while socialism creates the necessary base, economic and political, for independence." ${ }^{51}$ This was an ultimatum to the NDP: to be a relevant political force in the 1970s, the party must fully embrace an agenda of economic independence through socializing the means of production. For Watkins and his followers, any tinkering as proposed by Walter Gordon and many New Nationalist Liberals, was insufficient to the task at hand. Bold policies were needed to confront a pressing national concern. For Watkins and other left nationalists, capitalism condemned Canada to a colonial existence.

Watkins was concerned by the proliferation of American-based multinational corporations operating in Canada. He argued that economic independence was primarily about the ownership of the means of production, and Canada's sovereignty was threatened by the high extent of American ownership. Multinational corporations were the drivers of foreign investment and presented Canada with the pressing problem of having corporate decision-making take place in the United States. Watkins was direct in his assessment of the consequences for

\footnotetext{
50 Watkins, "Economic Independence and Socialism," in NDP Policy Papers, 1969, 1, CCF/NDP Fonds MG28 IV-I, vol. 398, file 3.

${ }^{51} \mathrm{Ibid}$.
} 
the Canadian-American relationship: "in the context of the Cold War it has become evident that foreign ownership means not only the exercise of power by numerous corporations but also the exercise of power by foreign governments, specifically the American government." 52 Watkins also believed that multinational corporations were a symptom of the ills of capitalism, "the issue posed by the multinational corporation is not necessarily the nationality of ownership, but rather capitalism itself." Multinational corporations represented the "globalization of corporate capitalism," which he described as the highest stage of monopoly capitalism, a global military-industrial complex. If one subscribed to this interpretation, one believed that countries that hosted high levels of foreign capital became the satellites of the capitalist metropolis, locked perpetually into a pattern of "underdevelopment and unbalanced growth." ${ }^{53}$ Not only was there a threat to national sovereignty, but also to a viable economy.

Watkins proposed two strategies to the NDP that could address the twin problems of encroachments on Canadian sovereignty and long-term economic decline due to American direct investment: "independence for its own sake" and "socialism for its own sake and for the sake of independence." In his examination of these strategies, Watkins argued that the latter was preferable and most promising, since the "independence for its own sake" strategies of New Nationalists were

\footnotetext{
52 Watkins referred to the American Trading with the Enemy Act, which prohibited American owned corporations from trading with communist countries. This American policy was all the more concerning for Canada because it insisted on including American-owned Canadian corporations in its jurisdiction, which limited both Canada's ability to open trade with the Soviet bloc and independent maneuvering in Cold War geopolitics. Watkins, “Economic Independence and Socialism," 3.

53 Ibid.
} 
inherently capitalist and thus insufficient to deal with the problems Canada faced. Watkins described the first option as a modest proposal for dealing with the issue of foreign direct investment. Its primary aims were to protect Canada from limits to its sovereignty; regulate multinationals so they resembled good corporate citizens; strengthen the Canadian business class; and keep key sectors ${ }^{54}$ under Canadian ownership. This strategy, while promising because it could rally nationalists of various stripes, was according to Watkins "too little too late." 55 Watkins believed this policy prescription might have worked if implemented in the early days of increased American investment, such as the immediate post-war period. However, the unchecked growth of American direct investment in the preceding two decades meant that a more radical, left nationalist option was Canada's best hope to preserve its independence.

The left nationalist project of "socialism for its own sake and for the sake of independence" was presented to the NDP as Watkins' best option for securing independence and the party's long-stated social-democratic policy goals. This option would pursue the national planning of investment, public ownership of key sectors of the economy and "the replacement of the priorities of corporate capitalism with communal priorities, and of decisions by corporations with decisions by the people." Watkins noted that this "coming of socialism" awaited a mass base that could be achieved by taking into account aspirations for independence. ${ }^{56}$ By tying socialism

\footnotetext{
${ }^{54}$ Key sectors of the economy outlined by Watkins included the transportation, finance, and resources.

55 Watkins, "Economic Independence and Socialism," 4.

${ }^{56}$ Ibid., 4-5.
} 
to aspirations for Canadian independence, Watkins hoped it could create a coalition of support, with voters rallying to the socialist, anti-imperialist, and nationalist cause.

Watkins addressed another growing concern within the NDP, the prevalence of international, mostly American, controlled unions. However, Watkins argued that rather than concentrating on Canadianizing the unions, the priority should be to diminish the power and prevalence of the multinationals. Once in place, an independent Canadian economy led by a socialist government would serve to foster the emergence of powerful national unions. ${ }^{57}$ Nationalization of the economy was the only way to make it truly Canadian. Once this occurred the unions would also be nationalized. In addition to a state-run Canada Development Corporation, Watkins argued that an NDP-led national government must pursue the objective of an independent socialist Canada through policies of "rationalization, nationalization, resource planning, greater independence from the United States [in domestic and foreign policy], and the strengthening of national institutions." 58 Watkins made the case that, if the NDP was to take itself seriously as a socialist party, then it must fully commit to securing Canada's independence by embracing left nationalism.

Not all Canadian leftists were fully on board with the emerging left nationalist movement. Earlier in 1968, the lesser known socialist and Trotskyist group, the League for Socialist Action (LSA), held a convention where the issues of nationalism and socialism were discussed. Part of the international Marxist

57 Watkins, "Economic Independence and Socialism," 5.

58 Ibid., 8. 
movement, Trotskyists were those who supported neither the earlier Stalinism of the Soviet Union nor the Maoism of the People's Republic of China. Trotskyists advocated a permanent international proletarian revolution and sought the creation of vanguard movements throughout the bourgeois (Liberal) democracies. While not officially affiliated with the NDP, Trotskyists in the LSA had contributed to its policy debates and actively supported party candidates at elections. The LSA members were skeptical of the Waffle because they viewed nationalism as a bourgeois tool and a distraction from the issue at hand: the overthrow of American capitalist imperialism and the establishment of world socialism.

The LSA had sought to influence the policy agenda of the NDP since the party's founding in 1961 and some of its supporters were active in NDP circles. In 1969 the LSA once again attempted to introduce their agenda into the party's policy making process. Like Watkins and others, the LSA identified the problem of Canadian political economy, described as a "longstanding and now built-in deficit in trade relations," and "the extent of U.S. capital investment in the Canadian economy." 59 The LSA had little patience for "Liberal" or "capitalist" nationalism, which was regarded as a "tool of the ruling class." The LSA was also skeptical about attempts of buy-back programs aimed at increasing Canadian ownership of corporations and limiting foreign investment, viewing them as a means of the Canadian capitalist class to strengthen its control of the state. While the subject of much debate, the LSA ultimately agreed with the left nationalist description of the

\footnotetext{
59 League for Socialist Action, "The Debate on Canadian Nationalism: the 1968 Resolution," in Socialist History Project. http://www.socialisthistory.ca/Docs/1961-/CanNat/CanadaUS-68.htm
} 
problem of American dependency and its socialist agenda. However, the LSA did not embrace nationalism, which it viewed as a tool of the bourgeoisie. After all, Trotskyism was antithetical to nationalism.

The LSA's position on Canadian nationalism was fully articulated in a resolution adopted at their 1969 convention titled “Canada-US Relations." 60 Canada was described as a "junior partner" of American capitalism. Both countries faced a reckoning due to the declining position of the United States and the impending “world socialist revolution." Canada's special relationship with the United States, as the junior partner of American imperialism, was both colonial and complicitous:

Far from seeking to conquer Canadian capitalism and to assimilate Canada into the United States, the American ruling class has sensitively developed a special role for Canada in their global imperialist strategy. Washington has made special adjustments and concessions in order to keep the Canadian economy on an even keel. It has exempted U.S. investment in Canada from complying to special regulations that would have created difficulties for the Canadian economy. It has developed a working relationship which places the preservation of Canadian imperialist investments under the protective wing of the rapacious eagle. It has even worked out plans whereby it could hope to effectively quell revolutionary developments in Canada which might imperil U.S.-Canadian capitalist interests. ${ }^{61}$

Using similar language to that of the Waffle Manifesto, the resolution declared that, in return for special status, "the Canadian bourgeoisie have defended all down the line the unpopular U.S. imperialist assault against the Vietnamese people, remained committed to the costly and completely militarily outmoded alliances of NATO and NORAD, and suffered the ignominy of U.S.-controlled corporations flagrantly violating Canadian law." The LSA, however, had little patience for the mainstream

${ }^{60}$ League for Socialist Action, "The Debate on Canadian Nationalism."

${ }^{61} \mathrm{Ibid}$. 
English Canadian left's initial emphasis of nationalism at the expense of socialism. ${ }^{62}$

The LSA wanted to abandon talk of nationalism and instead emphasize "antiimperialism." The resolution was a source of debate into the 1970 s, with a majority later expressing sympathy for left nationalism, while a minority group led by the Trotskyist Ross Dowson remained firmly against nationalism as the foundation of a socialist political agenda. ${ }^{63}$

Left nationalism was often met with dismissal in the press. In a demonstration of the skepticism that the left nationalists initially faced when discussing their ideals outside like-minded circles, an editorial in the Globe and Mail, titled “A Basis for Discussion," suggested that many of the policy proposals in Socialism Canada '70s were an "attack on democracy." The editorial quoted political scientist Gad Horowitz's assertion that “the task of a left party is to agitate," and suggested that it should be amended to say, "the task of a left party is not to govern." Again, referring to the wider Cold War, the editorialists argued that there is a "failure to recognize reality" within the NDP, and "what all the booklet's contradictions add up to is something the Canadian people are unlikely to accept. It preaches democracy; what it would impose would require authoritarianism." By "contradictions," it was likely referring to the diverging approaches to economic nationalism. The editorial claimed that nationalism was an exercise in antiAmericanism, "telling the Canadian people what is best for them, damning

\footnotetext{
62 The LSA was disappointed with Canadian Dimension's early support for leftists emphasizing nationalism at the expense of socialism. The adopted resolution described the periodical as "an important journal of liberal petty bourgeois opinion with considerable influence in NDP intellectual circles."

${ }^{63}$ Ian Angus, "The Debate on Canadian Nationalism, 1968-73: Introduction," in Socialist History Project. https://www.socialisthistory.ca/Docs/1961-/CanNat/CanNatIntro.htm
} 
continentalism, and hating the United States." 64 Reaction in other media outlets was not as severe as that in the Globe and Mail, ranging from sceptical to uninterested. 65 Press reaction made it clear to many left activists that more was needed if the NDP was to gain popular appeal for proposals for securing independence from American multinationals and establishing democratic socialism. But, it was also a warning that the party should proceed with caution in dealing with the Waffle Manifesto.

The Waffle at the 1969 NDP Policy Convention

At the time of its launch, the Waffle Manifesto was characterized as a radical document by both its supporters and detractors. Reaction from the press, New Nationalists, and the NDP leadership was highly critical. Concerned with its Marxist overtones, columnist Charles Lynch accused the manifesto's authors of acting in the interests of international Communism. Douglas Fisher and Harry Crowe, writing in the Toronto Telegram, condemned the manifesto as a "jumble of discarded slogans of the 1930s, a nostalgia of guild socialism, and above all a frenzy of antiAmericanism." 66 The New Nationalist Abraham Rotstein disliked what he thought was the manifesto's anti-American tone, arguing that it was based on a "reaction to America at a low point in its history [and was] in my view, not an enduring basis on

\footnotetext{
${ }^{64}$ In another example of the hostility aimed at the NDP's proposed policy agenda, Bruce Lawson's proposal for bringing in further public funding of broadcasting in Canada through the establishment of a cooperative style rival to the CBC was equated with communism. "A Basis for Discussion (II)," Globe and Mail, July 10, 1969, 6.

65 Desmond Morton, The New Democrats, 1961-1986: The Politics of Change (Toronto: Copp, Clark, Pitman, 1986), 93.

${ }^{66}$ Douglas Fisher and Harry Crowe, quoted in Bullen, "The Ontario Waffle," 194-95.
} 
which to construct the edifice of Canadian independence." 67 Deputy NDP leader

David Lewis criticized the manifesto's "self-righteous view of the United States" and its obsession with public ownership, calling it "short-sighted thinking for a socialist to aim his shafts only against foreign-owned corporations ... the economy has progressed, and there are many other tools available in addition to public ownership." 68 However, the NDP leadership could not ignore or dismiss the manifesto since its publication triggered a debate over how the party should chart a new course for the 1970s. At the 1969 federal convention, the party was confronted with the manifesto, and the debate that followed illustrated how economic nationalism had diverged into left and moderate camps.

The Waffle Manifesto was introduced as policy resolution R-133, "For an Independent Socialist Canada," and garnered significant support from delegates. Writing in a Canadian Dimension preview of the convention, Gonick had downplayed its chances of adoption. He claimed, "the purpose of the statement, as we understand it, is not to win votes at the Winnipeg convention - but to flush out and help identify the left inside the NDP - and to organize it into a coherent and dynamic

\footnotetext{
${ }^{67}$ Rotstein, the editor of Canadian Forum, co-founder of the Committee for an Independent Canada, and an economics professor at the University of Toronto, was a leftist who was not associated with the left nationalist movement. He thought the problems facing the United States, of which the left was highly critical, were temporary, and wondered if the Waffle would be able to sustain itself once the Americans addressed the issues of "militarism abroad and racism at home." Along with Walter Gordon and Peter C. Newman, Rotstein later founded the Committee for an Independent Canada (CIC) as a vehicle countering the left nationalism of the Waffle movement while advocating for measures to deal with American dependency. Abraham Rotstein. quoted in Bullen, "The Ontario Waffle," 194-95.

${ }^{68}$ David Lewis quoted in The New Democrat, September-October 1969, CCF/NDP Fonds MG 28 IV-I, vol. 403, file 10 .
} 
political vehicle, within the party. If this is accomplished, the statement will have served a useful and important function." 69

The NDP's leadership feared that the convention would be consumed by the Waffle manifesto. The party executive sought to outmaneuver the Waffle supporters by introducing a resolution that called for a more moderate version of economic nationalism. David Lewis and Charles Taylor introduced Resolution C-17, "For a United and Independent Canada," which called for economic nationalism and socialism but fell short of proposing the radical alternatives of socializing the financial industry and means of production. Waffle supporters such as Watkins dubbed the resolution the "Marshmallow Manifesto" because of its comparatively moderate stance. The debate over the two manifestos became the defining moment of the convention and ensured that the Waffle Manifesto would remain at the forefront of policy debates within the NDP into the early 1970s.

In contrast to the radicalism of the Waffle Manifesto, Resolution C-17 called for the NDP to place the utmost importance on securing Canada's independence by embracing a social democratic agenda. It declared that the "New Democratic Party seeks to make and keep Canada free to realize the full potential and greatness of her people." This freedom was based on the ability to build a "modern and efficient economy free of the control of private corporate power, whether foreign and domestic; and to play a truly independent and meaningful role in the world." ${ }^{70}$ The

${ }^{69}$ Gonick, “The Waffle Manifesto," Canadian Dimension, October-November 1969, 5.

70 Resolution C-17: "For a United and Independent Canada," in Resolutions: New Democratic Party Fifth Federal Convention, Winnipeg, October 28-31, 1969, 15, CCF/NDP Fonds, MG28 IV-I. vol. 398, file 12. 
resolution called for a program of social democracy, arguing, in vague terms, that the "struggle for an independent Canada" was tied to the struggle for "a better society." To succeed in this endeavour, the resolution declared that there must be "Canadian control of the economy, public control of investment and other priorities, and democratic social planning." It explicitly stated that Canada's future was "in peril" due to the foreign ownership of industry and resources. Attempting to differentiate the NDP from the Liberals and Progressive Conservatives, and attract support from those concerned with American dependency, the resolution claimed that the other parties represented "continentalism." In contrast, "the NDP strove for Canadian independence and survival as a free nation." The NDP was urged to commit to expanding public investment and public ownership, government planning, investment controls, a just tax system, monetary policy free from exchange rate constraints, and laws to regulate foreign investment and subsidiaries - in other words, the adoption of the New Nationalist agenda. ${ }^{71}$ Resolution C-17 concluded with a declaration of economic nationalism, urging Canadians to "free their country from the foreign domination of its economy, or its cultural development, and of its international policies."

Compared to the Waffle Manifesto, Resolution C-17 was a vague and moderate document. There was no mention of an "American Empire" or the full socialization of the financial sector, government ownership of natural resources, elimination of all foreign control of business, or the replacement of capitalism with socialism. In what was perhaps an attempt to earn the support of left nationalists,

71 "For a United and Independent Canada." 
the resolution refuted the charge that opposing American dependency meant embracing anti-Americanism:

Old party spokesmen are fond of decrying concern for Canadian independence as anti-American. Nothing shows more clearly how little they understand the feelings of Canadians. Anti-Americanism is as barren and negative a concept as is anti-French or anti-English or anti any other country or people. Canadians have always known this. What New Democrats seek is to make and keep Canada free to realize her full potential and greatness. We must regain control of our national future, not because of sentimental patriotism but because it is the only foundation on which we can build a better society. ${ }^{72}$

Despite this call for regaining control of the economy, this statement did not constitute revolutionary or radical rhetoric. Nor was it an expression of left nationalism. However, the resolution was what historian John Bullen described as a clear indication that the NDP leadership took the threat of the Waffle group seriously, and it was the most significant and aggressive position on economic nationalism that the party leadership had embraced..$^{73}$ It was clear that the Wafflers were influencing the policy debate within the NDP.

On October 30 the back-room and convention floor maneuverings over Resolutions C-17 and R-133 culminated in a debate between the two camps when both resolutions were put up for adoption on the floor. Speaking in favour of C-17 were co-sponsors David Lewis and Charles Taylor, party leader Tommy Douglas, future leadership candidates Ed Broadbent and John Harney, and party stalwarts Donald C. MacDonald, Alan Blakeney, and Sydney Green. Speaking in favour of Resolution R-133, "For an Independent Socialist Canada” were Waffle founders

\footnotetext{
72 "For a United and Independent Canada."

${ }^{73}$ Bullen, "The Ontario Waffle," 197.
} 
Watkins, Gonick, Laurier Lapierre, Gordon Dowding, and Gerald Caplan, among others. Waffle supporters made it clear that they did not support the small concessions given by the leadership in C-17 and, when the resolution was introduced to the floor by Lewis, Watkins countered by proposing that it be referred back to committee where it would be rewritten to reflect the Waffle Manifesto (R133). ${ }^{74}$ The nationalist movement in the NDP was splitting into a left camp represented by Waffle supporters, and moderates represented by David Lewis and the party leadership. This split between left and New Nationalists would persist into the mid-1970s.

In a debate carried live on national television, Lewis and his supporters confronted Watkins and the Waffle backers. In his opening remarks, Lewis sought to capture the spirit of the Waffle Movement without using its forceful and radical language regarding public ownership. Speaking on behalf of the party executive, Lewis stressed that the themes of the convention were "socialism in the 1970s," and a "united and independent Canada." He insisted that the NDP must become the party of moderate economic nationalism. Lewis argued it was time for a democratic socialist party to declare its determination to free Canada from "the foreign domination of its economy and the threat to its independence." However, Lewis was not enthusiastic about the bombastic and radical language in the Waffle Manifesto. He claimed that the party's hoped-for embrace of moderate economic nationalism would not be made out of "narrow chauvinism," an "arid nationalism," or

${ }^{74}$ Debate on the Resolutions: "For a United and Independent Canada" (C-17) and "For an Independent Socialist Canada" (R-133), 2, CCF/NDP Fonds MG28 IV-I, vol. 398, file 12. Hereafter Debate on the Resolutions. 
"ideological nonsense." Instead, the leadership, represented by Lewis, decided to present Resolution C-17 because they believed that economic freedom must be achieved to preserve the political freedom necessary to build socialism. ${ }^{75}$

Lewis, his supporters, and the party leadership never really articulated what economic and political freedom entailed, or what their vision of socialism was. Lewis acknowledged that there was unease in the Canadian public about the "foreign domination" of the economy. He also insisted that the resolution was a "strong statement in its condemnation of foreign domination ... and [in support] of the objectives of the Canadian people." 76 He urged delegates to support his moderate resolution against the Waffle group precisely because it was not loaded with ideological language and specific programs. "There are some of my colleagues . .. who state that the only time you are a socialist is when you say socialist. Well, I said socialist for many years, but the people of the country want to know what you mean by socialism ... It is a strong statement because it is specific in approach and it doesn't put itself into any ideological straight-jacket." 77 He pleaded with the delegates to reject the language put forward by the Waffle group, arguing, “... to bury this central problem of independence in a general statement of analysis ... [and] words which are foreign to the Canadian people, to clothe it in incomprehensible language ... is to betray the principle of independence in

\footnotetext{
${ }^{75}$ Debate on the Resolutions, 3.

76 Ibid.

${ }^{77}$ Ibid., 4.
} 
Canada."78 This call for action, without outlining specifics, did nothing to convince the Waffle supporters to change sides.

Watkins responded to Lewis' position by urging delegates to embrace new ideas and bold action firmly based on a socialist agenda. He positioned the Waffle group as receptive to the new demands for left nationalism in Canada. "All socialists" to join new causes and challenge old views. Firmly rejecting the leadership's moderate positions, Watkins argued that the NDP must accept the "under-currents of radicalism" and become the parliamentary wing of a broadbased socialist movement. He claimed that the time was right for a party of the democratic left to seize the agenda. The reactionary "politics of the Cold War" had ended, and, with the NDP's leadership, the 1970s could be the decade where socialism finally took root in Canada. Watkins told delegates that those on the left must be concerned with more than just winning an election, they should be preoccupied with seizing power from the American led global military-industrial state. ${ }^{79}$ Reflecting the tone of his policy paper for Socialism Canada 70 s, Watkins described his view of the present political economy of the capitalist system, based in the anti-imperialism of fellow Wafflers. "The Western World today is dominated by a small number of giant corporations, mostly American based. These corporations and the American Government, with which they are so closely related, are the new industrial state, [and] the essence of the military-industrial complex." ${ }^{80} \mathrm{He}$ implored delegates to commit to arresting this development since it imperilled Canada's

\footnotetext{
78 Debate on the Resolutions, 4.

${ }^{79}$ Ibid.

${ }^{80}$ Ibid., 5
} 
independence. He believed there was still hope. "Continentalism and capitalism have gone together in the past, independence and socialism must go together in the future." Watkins insisted that only the NDP had the "will and the means to halt this slide into dependency" through nationalization of industry and commerce. ${ }^{81}$ Watkins message was clear. Capitalism brought continentalism, and socialism would bring independence. For left nationalists there was no waffling on that issue.

Speaking to Resolution C-17, Watkins acknowledged that it recognized the need to preserve Canada's economic independence, but he believed it was vague on the other stated goal of socialism. Conscious that his remarks were broadcast on live television, Watkins made sure to summarize the aims of the Waffle movement. He argued that Resolution R-133 was about socialism, defined as a concern with building a society based on "equality of position" by taking the lead sectors of the economy under public ownership. The Waffle Manifesto was, contrary to the view in the press and espoused by the party leadership, not a narrow document focussed only on nationalization. The Waffle Manifesto and Resolution R-133, Watkins insisted, were for "democratizing" the workplace and communities, and building a mass movement that would propel the NDP to power. Gonick supported this sentiment, telling delegates that the NDP in its present state was a product of the affluence of the 1950s, when many thought capitalism had solved most of the problems of inequality, with social spending designed to preserve affluence for as

${ }^{81}$ Debate on the Resolutions, 5. 
many people possible. According to Gonick, that view of capitalism was now outdated and the Waffle Manifesto reflected the changing times..$^{82}$

Watkins also addressed the claim made by his detractors that the Waffle Manifesto was anti-American, claiming instead that the Manifesto reflected the spirit of the New Left in the United States. "To call such a clear statement of socialist principles anti-American ... is to profoundly miss our point. A growing number of Americans reject American militarism and their exploitation of the developing world by its multinational corporations." ${ }^{83}$ Anti-imperialism was often falsely equated with anti-Americanism. It was the Waffle Manifesto's attacks on the American empire and capitalism that led its detractors to say it was an antiAmerican document. Even ardent socialists who were receptive to the Waffle's program of public ownership and the socialization of the means of production were critical of its perceived anti-American overtones.

Wafflers identified the American-led unions as constituting a potential obstacle to their agenda. These concerns were reinforced when Dennis McDermott, the director of the United Autoworkers (UAW), attacked the Waffle group as narrow-minded and fixated on a "crucifixion" of the United States. He also implored delegates not to accept independence premised on isolation. McDermott believed that an entire country could not be dismissed or condemned because of the policies of its government. McDermott pointed to the left's allies in the United States, people whom he had worked with as an international trade unionist:

82 Debate on the Resolutions, 5.

83 Ibid., 5-6. 
I am concerned about the blighted anti-Americanism that is manifest in this document ... I am just as concerned about the United States' reactionary foreign and domestic policy ... the industrial military complex ... the antics of [American president] Nixon ... and the frightening spectacle of the Pentagon moving into the White House as anyone else here. But I say to you that contempt for Nixon ... more than countered by the people that I work with. ${ }^{84}$

McDermott believed that the Waffle's reference to the United States and its economic system unfairly signaled out the many leftists in the country who worked for similar goals. This internationalist sentiment held by McDermott was common in the moderate wing of the NDP, especially the trade unions, many of which had ties or were affiliated with American unions. For these moderates and internationalists, the Waffle Manifesto was unfair to the Americans. The reactionary policies of the American government were those of the Nixon White House, not the "American Empire."

Continuing with the theme of foreign policy and Canada's place in the capitalist world system, Waffle co-founder Gerald Caplan spoke to delegates about Canada's relationship with the "Third World" (developing world), and how it related to the struggle to preserve Canada's independence by adopting socialism. He argued that despite the recent process of decolonization, the poor nations of the developing world were kept that way because the capitalist West wanted to maintain a system of dependence based on the exploitation of resources. While others had argued that Canada found itself in a dependent situation similar to that of the developing world, Caplan believed that Canada was complicit in, not a victim of, the system of global capitalist exploitation. In Caplan's view, the Waffle Manifesto must be adopted

${ }^{84}$ Debate on the Resolutions 6. 
because only a program of socialism to establish Canada's independence could allow the country to break out of the system of exploitation and help "free" the developing world. ${ }^{85}$

NDP leader Tommy Douglas spoke out against adopting the Waffle Manifesto, describing it as "ambiguous and ambivalent" because it did not define what was meant by public ownership of the means of production. Douglas, wrongly speculating that farms would be nationalized, asked, "will somebody tell us what taking over a farm has got to do with stopping the American takeover of the Canadian economy? This is like suggesting to a man that he ought to burn down his house because he has got rats in the basement." ${ }^{86}$ Most delegates agreed with Douglas and supported his call to defeat resolution R-17 which called for the adoption of the Waffle Manifesto. The vote was 268 in support and 499 against.

The Waffle agenda was not entirely defeated. There was consensus on the issue of neutralism and on the need to endorse some form of economic nationalism. Delegates adopted a Waffle-sponsored resolution that called for an NDP government to end Canadian involvement in the North American Air Defence Agreement (NORAD), NATO and joint US-Canada military agreements. This neutralist resolution argued that the original aims of NATO would never be fulfilled, and pointed to the alliance's failure to condemn the oppressive military dictatorship in Greece as an examples of how the alliance was not a force for the preservation of freedom and

${ }^{85}$ Debate on the Resolutions, 12.

${ }^{86}$ Ibid. 
democracy in Europe. ${ }^{87}$ The money saved by withdrawing from the American alliance system would be used to build a large professional army that would be fully committed to United Nations peacekeeping. Resolution 11 on foreign ownership, promoted as a compromise on economic nationalism, and calling for extended government intervention in the economy and greater restrictions on foreign owned companies, was passed by delegates with broad support. The resolution argued that American-based multinational corporations were the "dominant institutions in Canadian life." However, the resolution did not use left nationalist rhetoric. Instead, it employed moderate language that avoided terms such as "empire" and "imperialism," and declared that Canada had been reduced to a resource and consumer base within the American economy. 88

Other non-Waffle sponsored resolutions dealing with American dependency were supported by delegates. The party adopted the position that democratic socialism would reduce the influence of multinational corporations, with the immediate priority being to compel them to "perform in the Canadian public interest," with the long-term goal of the building of an independent economy "where the priorities of social development are set within Canada by Canadians." Rather than calling for the immediate seizure of the means of production and the nationalization of key sectors of the Canadian economy, the resolution called for comparatively muted measures based on the creation of "integrated set of national

87 Resolutions Approved by Convention, 36-37, CCF/NDP Fonds MG28 IV-I, vol. 398, file 15. Hereafter Resolutions Approved by Convention.

${ }^{88}$ Resolutions Approved by Convention, 36-37. 
policies to stop the further slide of Canada into dependent status." ${ }^{89}$ Despite their rejection of most of the Waffle's agenda, delegates were clear in their desire to have the NDP remain the party of moderate economic nationalism.

With consequences for the 1971 leadership convention, the delegates also passed the Waffle sponsored Resolution S-2, permitting party activists to engage in increased extra-parliamentary activity, which had the effect of allowing the Waffle to operate somewhat independently of the NDP over the next several years. Watkins was elected as a party vice president, and eight other Waffle supporters were elected to positions on the federal council, with James Laxer appointed to chair a committee charged with examining NDP activities at the community level. ${ }^{90}$

\section{Conclusion}

The NDP emerged from the convention with a moderate economic nationalist agenda. The Waffle was mostly responsible for the nationalist turn, since it galvanized growing nationalist sentiment in NDP circles, and pushed the party leadership to counter the Waffle with a moderate agenda. This was significant because the Liberal and Progressive Conservative parties did not yet embrace economic nationalism as part of their policy thinking.

\footnotetext{
${ }^{89}$ The specific policy proposals were such as requiring the full disclosure of the financial data of foreign-owned corporations; the creation of a government export trade agency that would block the intrusion of American law; public control of foreign takeovers; the creation of a Canada Development Corporation; the expansion of public and cooperative ownership in key sectors of the economy; and the creation of an unspecified "integrated set of national policies to stop the further slide of Canada into dependent status;" and replacing the branch plant economy with "an efficient, profitable, Canadian economy." Resolutions Approved by Convention, 37.

${ }^{90}$ Bullen, "The Ontario Waffle," 197-98.
} 
In 1970 when asked to recollect on the events surrounding the launch of the

Waffle Manifesto, Watkins insisted that the Waffle group's initial intent had not been to radicalize the NDP. However, subsequent events led Watkins to change his mind. Watkins recalled, "none of us who wrote the Waffle Manifesto, and certainly myself, never sat down as said: 'Let's radicalize the NDP.' It was much more of a spontaneous thing of a half dozen or so people realizing they were in the Party and fed up with it." 91 Yet the Waffle Manifesto was a radical document, and by forcing a debate on left nationalism, it tested the limits of the NDP's commitment to socialism. The Waffle's detractors and supporters of C-17 argued that the manifesto's emphasis on full public ownership of the economy, and its apparent anti-American tone, would not appeal to a wide range of voters and was no way to win power. This demonstrated that the NDP was reluctant to become a radical party for social change, and the Waffle's characterization of the party as a moderate social democratic one was sound.

The debate over nationalism in the NDP at the 1969 convention revealed the diverse array of opinions regarding Canada's relationship with the United States and the national question. As the conflict in the NDP over the Waffle intensified, it became clear that economic nationalism on the Canadian left had gone in into two distinct directions. The left nationalist position, represented by the Waffle Manifesto, combined anti-imperialist sentiment and the democratic socialist

\footnotetext{
${ }^{91}$ Mel Watkins, "Waffles and Marshmallows: The Future of the NDP," in Gordon to Watkins to You: A Documentary Battle for Control of our Economy, ed. Dave Godfrey and Mel Watkins (Toronto: New Press, 1970), 102. Watkins later changed his mind after the events surrounding the 1971 leadership race. He argued in 1990 that it actually was the Waffle's intention to radicalize the NDP. Mel Watkins, "The Waffle and the National Question," Studies in Political Economy 32 (1990), 131.
} 
political ideology into a program of a radical overhaul of Canada's political economy and relations with the United States.

In contrast, the moderate economic nationalist position, supported by the NDP establishment and the majority of convention delegates, was represented by the Marshmallow Resolution. Like the left nationalists, they agreed that there was a problem of American dependency and that Canada needed to embrace a leftist agenda to ensure its independence. Unlike the left nationalists, however, the moderates wanted reform through government regulation of foreign takeovers and the creation of a Canada Development Corporation to buy-back the economy. Espousing the social democratic agenda, these New Nationalists wanted to reform capitalism rather than replace it and to forge a more independent foreign policy rather than pursue a complete break with the "American Empire." There were also anti-imperialists who resisted the nationalist label. These non-nationalist antiimperialists were mostly associated with the League for Socialist Action and described themselves as Trotskyists. As indicated by their statement on CanadaUnited States relations, these Trotskyists were international in their outlook and viewed the struggle against American imperialism as part of a global left movement. They believed the debate over economic nationalism in the NDP was a distraction from the task at hand: the global struggle against the American empire.

Despite these divisions, the Waffle managed to secure a position within the NDP. Laxer's and Watkins' push to transform the NDP into a party committed to building a socialist state with an independent economy and foreign policy culminated in the battle for the party leadership in 1971. Ultimately, the debates 
over Canadian foreign policy, and concerns over relations with the United States, American dependency, and nationalization, had demonstrated that the NDP leadership was not ready, willing, or able to adopt the politics of left nationalism. Nevertheless, a significant left nationalist camp emerged in the NDP which confronted the comparatively moderate agenda of the party leadership.

Moderates in the party were concerned that the United States was dominating Canada's economy and hampering its freedom to conduct an independent foreign policy but advocated only gradualist measures of change. This contrasted sharply with the left nationalists who sought the transformation of Canada into a truly independent democratic socialist country through a program of nationalisation and neutralism. The next two years witnessed not only a struggle to define the NDP in the 1970s, but also a debate in the English Canadian left over the nature of economic nationalism, Canada's economic and political relations with the United States, and the extent to which left nationalism should form the basis of leftist politics. 


\section{Chapter 2: \\ The Waffle's Populist Aspirations and Anti-Imperialist Agenda, 1969-1974}

Undaunted by the rejection of the Waffle Manifesto by delegates to the 1969 NDP policy convention, James Laxer and Mel Watkins intensified their efforts to advance the cause of left nationalism within the NDP during a period of increased anxiety about American dependency and an unreliable United States. When NDP leader Tommy Douglas announced his resignation in 1971, Laxer decided to run for the party leadership. Laxer believed the political climate gave him a chance of winning the leadership over the preferred candidate of the party establishment, David Lewis. Described by opponent Desmond Morton as "rhetorical radicals," the Waffle embraced populism when campaigning for the NDP leadership and advocating for their left nationalist agenda.

In November 1970, journalist Walter Stewart wrote, "at heart [Watkins] is a populist." ${ }^{1}$ This populist label, referring to both rhetoric and tactics, could also be extended to the Waffle and the wider left nationalist movement. The Waffle's campaign for control of the NDP during the 1971 leadership race was premised on an appeal to a left populist agenda. The political scientist Chantal Mouffe described left populism as a movement that emerged out of the 1960s protest movements that resulted from various resistances against forms of domination. It challenged the hegemony of the Old Left of reformist social democracy and instead wanted to

\footnotetext{
1 Walter Stewart, "On the Left, Mel Watkins. In the Middle, Joe Greene. The Heavyweight Contest to Choose Captain Canada of 1971," Maclean's, 1 November 1970, 32.
} 
remake politics to act in the interests of the people over elites. Left populists challenged political orthodoxy and led campaigns of resistance and insurgency. ${ }^{2}$ According to this definition, the Waffle was a populist movement because of its emphasis on advancing democratic socialism in the interests of the people against the elites, fighting the NDP establishment, and advocating Canada's liberation from American dependency. Watkins accepted the populist label and characterized his democratic socialist agenda in terms that reflected populist rhetoric. Watkins explained,

when we talk about socialism as democratic socialism, we should see that the word 'democratic' means not simply building socialism by democratic means in the sense of gaining power electorally, but by a whole new meaning for democracy that goes far beyond what it has come to mean in practice in the west. It means redistribution of power, from elites who have it now, to the people. It means democracy at every level of decision-making ... And that is how you tell the New Left from the Old Left. ${ }^{3}$

This was hardly surprising for someone who responded to the charge of "you just want to smash everything and start again" with a simple "yes." ${ }^{4}$ Watkins, however, declined the opportunity to run for the leadership of the NDP. Instead, James Laxer took up the task of advancing the left nationalist agenda.

This chapter studies how the English Canadian left nationalist movement was represented by James Laxer's leadership campaign and the policy agenda of the Waffle. Left nationalism fueled concerns about American dependency, challenged the moderation that characterized the NDP, and exposed the lack of a Marxist

\footnotetext{
${ }^{2}$ Chantal Mouffe, For a Left Populism (London: Verso, 2019), 2-3.

3 Mel Watkins, "Getting to Democratic Socialism 4: Here and Now," in Gordon to Watkins to You: A Documentary: The Battle for the Control of Our Economy, ed. Dave Godfrey and Mel Watkins (Toronto: New Press, 1970), 137.

${ }^{4}$ Stewart, "On the Left, Mel Watkins. In the Middle, Joe Greene," 35.
} 
tradition in Canadian politics. Laxer's loss in the leadership race and the Waffle's subsequent expulsion from the NDP indicated that the left nationalist agenda failed to gain the mass support it hoped for, and ultimately pushed it outside the parameters of mainstream politics. This chapter examines Laxer's campaign for the leadership, the Waffle's policy agenda, and the way the NDP responded to the challenge of the left nationalist agenda while confronting the problem of American dependency during the years surrounding the 1971 convention.

In 1971 it was evident there were significant differences in the approach to economic nationalism between the leftists in the Waffle and the moderates in the party establishment. English Canadian left nationalism represented a new political force, one that was based on democratic socialism and anti-imperialism, in contrast to the moderate social democratic politics of the NDP and its predecessor, the Cooperative Commonwealth Federation (CCF). Left nationalists agreed with the Waffle Manifesto's premise that "the fundamental threat was external," and most agreed with the assertion that the United States' economic and geopolitical power was the main threat to Canada's survival as a nation. Left nationalists advocated the replacement of capitalism with socialism to preserve Canada's independence against the United States. In contrast, New Nationalists preferred to reform capitalism and regarded the problem of American dependency as one that could be addressed though technocratic government regulation. In this climate of ongoing debate and conflict between the two nationalist camps, Laxer and his supporters realized that the time was opportune to take control of the NDP as the best and quickest means of advancing the Waffle Manifesto. 
Laxer had long-held anti-elitist views which formed the basis for his aspirational populism. Laxer's 1971 leadership campaign was populist because it was anti-elitist. As early as 1966, he blamed the Canadian business elite for the problems of American dependency, writing that the "responsibility for continental inroads into Canadian nationhood cannot be seen as American alone. The Canadian economic elite has, in large measures, willed its self-destruction as the dominant class in an independent country." ${ }^{5}$ Laxer railed against elites in the NDP and the business and labour community and claimed to be acting in the interests of workers. He combined this populist rhetoric with an agenda of left nationalism to advance a vision of a Canada that was to be stronger, independent, and more prosperous, with power in the hands of workers or the people.

Whether Laxer or his supporters embraced the populist label is not of concern. Instead, this chapter is interested in how his campaign used populist rhetoric to advance a left nationalist agenda. Laxer aimed to rally workers to the cause of left nationalism, which had been mostly tied to youth movements and the agitations of young intellectuals. Using populist rhetoric, Laxer sought to place left nationalism at the forefront of debates over the role of the state in the economy and to chart an independent course for Canadian economic and foreign policy in the 1970s. While establishment favourite David Lewis eventually won the leadership, Laxer provided the NDP with the debate it needed to decide what kind of party it

\footnotetext{
${ }^{5}$ James Laxer and Arthur Pape, "Youth and Canadian Politics," in Canada and Radical Social Change,
} ed. Dimitrios Roussopoulos (Montreal: Black Rose Books, 1973), 48. 
should become and was an essential contribution to the development of left nationalist sentiment.

The Nationalist and Populist Impulse

Earlier in 1970, the New Nationalist, editor of Canadian Forum, and Waffle opponent Abraham Rotstein, along with Liberal politicians and financier Walter Gordon, the journalist Peter C. Newman and others, had founded the Committee for an Independent Canada (CIC) as an alternative to the Waffle movement. ${ }^{6}$ Rotstein was a leftist who did not associate himself with the left nationalist movement. He was a social democrat who advocated reform to achieve Canadian economic independence. While Rotstein did not believe the Waffle's agenda was appropriate for addressing Canada's economic dependence on the United States, he mostly agreed with left nationalists on the causes and consequences of the American dominance of the Canadian economy. Rotstein blamed the Canadian acquiescence in American dependency on what he referred to as the liberal ideology that dominated the governing classes in general, and Liberal party in particular. Rotstein argued that liberalism and populism were the two defining political ideologies in Canada, with the latter occasionally emerging to temper and guide the policies of liberal capitalism. Looking back at the events of the early 1970s, Rotstein claimed that this populist impulse appeared to have taken the form of economic nationalism. ${ }^{7}$

\footnotetext{
${ }^{6}$ Ryan Edwardson, "Kicking Uncle Sam out of the 'Peaceable Kingdom': English Canadian New Nationalism and Americanization," Journal of Canadian Studies 37, no. 4 (Winter 2002-2003), 137-8. ${ }^{7}$ Abraham Rotstein, "Canada: The New Nationalism," Foreign Affairs 55, no. 1 (October 1976), 104.
} 
Writing in Foreign Affairs in 1976, Rotstein identified what he described as a historic populist tendency in Canadian political culture that emerged during times of hardship. He believed that the populist tendency re-emerged in the late 1960s and 1970s out of a desire to counter the growing influence of the United States. Canadian populism was defined by a "homestead mentality" based on the "politics of space" built on an anxiety of being in a constant state of siege, first against a harsh climate, and then against the United States. Populists wished to defend the "homestead," and, as a result, Canadians historically supported state intervention to preserve Canada's social order. ${ }^{8}$ In situating his nationalism as part of a long-held Canadian political tradition, Rotstein was attempting to give legitimacy to his nationalist project. New Nationalists were concerned with disseminating their ideas while staving off the Waffle, but Rotstein believed both the CIC and the Waffle represented the populist impulse. The left nationalism of the Waffle represented an extreme form of the homestead-defending populist tendency, unique in English Canadian political culture.

The widespread nationalist sentiment in the English Canadian left helped carry the Waffle's Ontario wing to success at the Ontario NDP convention in October 1970. The Ontario Waffle was not interested in the leadership race between Walter Pitman and Stephen Lewis, and it once again turned to winning victories on the convention floor. The Waffle succeeded in getting several significant resolutions passed on housing and women's liberation. Notably, the convention adopted a Waffle resolution on nationalizing Ontario's energy and resource industry. This

${ }^{8}$ Rotstein, “Canada: The New Nationalism,” 110-11. 
resolution was a major component in the Waffle's program of bringing about worker control of the country's resources. ${ }^{9}$ American-owned lumber mills and mining companies in Northern Ontario were a particular target. Many delegates were receptive to the radicalism of the Waffle, since many were frustrated by the party's poor performance in recent elections. ${ }^{10}$ The Waffle left nationalists, with their populist proposals on housing, women's liberation, and nationalization of resources, offered something new and exciting, even if many delegates and union members were apprehensive about building a Canada that was independent of the American-dominated continental political economy.

Bringing left nationalism to the Ontario NDP would have marked a significant victory for the movement. It would have elevated an agenda based on left nationalist politics. The Ontario Waffle believed that many of the problems surrounding continentalism existed in Ontario. ${ }^{11}$ It was in the southern part of the province and the mining sector in the north where American-owned branch plants and American controlled unions were most prevalent. Establishing an independent socialist Ontario meant transforming the province into one where the workers were not exploited by the American-controlled capitalists in Toronto. A populist resolution called for the end of Toronto's role as the "dominant metropolis of the provincial economy, [taking] its tribute from its hinterland, and ... resource-rich Northern Ontario." 12 According to the Ontario Waffle, unemployment and inflation were

\footnotetext{
${ }_{9}^{9}$ The Ontario Waffle, "For a Socialist Ontario in an Independent Socialist Canada," 2, CCF/NDP Fonds MG 28 IV-I, vol. 446, file 16. Hereafter "For A Socialist Ontario,"

${ }^{10}$ Robert Hackett, "Pie on the Sky: A History of the Ontario Waffle," Canadian Dimension, OctoberNovember 1980, 34.

11"For a Socialist Ontario," 2.

12 Ibid., 1.
} 
undermining workers in Ontario because labour was treated as a commodity, American-owned corporations regularly shut down factories, and the power of the state was used to weaken unions. Ontario's abundant natural resources were "alienated from the workers" and in the hands of foreign capitalists. While populist rhetoric was present, the Waffle nationalists also expressed Marxist sensibilities. They believed that capitalism brought imperialism, and Ontario was firmly in the grip of it.

The Ontario Waffle claimed the province was a microcosm of the problems of the Canadian-American relationship. Using anti-imperialist language, their resolution declared Ontario "a link in a long imperial chain," with corporate capitalism diverting wealth to the "shareholders of the American metropolis." Continuing the anti-imperialist theme, the Ontario Waffle claimed that the "continuing Americanization of Ontario not only turns Ontario into a branch plant society; it poses the chief threat to the achievement of Canadian independence... and socialism." ${ }^{13}$ The Ontario Progressive Conservative government was accused of being either complicit in the Americanization of the province, or an active supporter in promoting the American takeover of the economy. The Waffle argued that in addition to ceding internal control of the economy, Americanization brought American problems, such as unemployment and inflation. These problems could be overcome through an agenda that transferred power to citizens through extensive public and democratic control over investment and the nationalization of large corporations.

13 "For a Socialist Ontario," 1. 
The Ontario Waffle made a point of addressing charges that they were anti-

American, fearing the characterization would hamper their cause. The group explicitly described their agenda as anti-imperialist:

We must not be deterred by those who will try to dismiss us by labelling us 'anti-American,' for those who do so profoundly misunderstood. Our complaint is not against the American people and the progressive movements in that country, but against the American corporate, political, and cultural domination of Canada. Our condition makes necessary an antiimperialist struggle if we are to achieve socialism and independence. ${ }^{14}$

This stated affinity for the American left, which was also fighting American imperialist tendencies, had an unfortunate side effect. It made the Waffle susceptible to accusations that they were "Americanizing" Canadian politics by bringing the language and tactics of the American left into Canada. ${ }^{15}$

The 1971 Federal NDP Convention I: The Leadership Race

At the Waffle's first national convention in August 1970, delegates chose to contest the national NDP leadership and endorsed James Laxer as their candidate. ${ }^{16}$ Cy Gonick expressed initial apprehension about the task at hand because the Waffle had to face the challenge of navigating "visions of apocalyptic revolutionary transformation and the trap of evolutionary reformism." The Waffle could not merely rely on "revolutionary rhetoric," Gonick argued, because "just to state and

\footnotetext{
14 "For a Socialist Ontario," 6.

${ }^{15}$ Laxer admitted this in his "The Americanization of the Canadian Student Movement," in Close the 49th Parallel Etc.: The Americanization of Canada, ed. Ian Lumsden (Toronto: University of Toronto Press, 1970), 278.

${ }^{16}$ Watkins, the Waffle's first choice, declined to run for the leadership.
} 
restate the overall goal is to have no strategy at all." ${ }^{17}$ A successful strategy, perhaps, could be based on populism.

Laxer was able to garner significant attention as a newcomer to the political scene. From the start, he received widespread support amongst NDP members, particularly with youth, and media coverage ensured a sustained interest in his campaign. Laxer stood out against the other four candidates vying for the NDP leadership with his advocacy of the Waffle agenda. ${ }^{18}$ Establishment favourite Deputy Leader David Lewis and other candidates, John Harney, Ed Broadbent, and Frank Howard often attacked Laxer in unison for his ties to the Waffle, drawing further attention to his campaign. ${ }^{19}$ Yet, by the end of 1970, it was clear that Laxer was the primary challenger to Lewis.

Lewis did not believe that the party would embrace the Waffle's left nationalist and populist agenda. In a press release, he declared he was "certain that the convention ... will defeat the more extreme, unrealistic and doctrinaire Waffle proposals and hoped that an end may be brought to the divisive factionalism which is as unnecessary as it is dangerous." ${ }^{20}$ He also doubted the merits of public ownership of major sectors of the economy and believed Laxer's and the Waffle's agenda was dangerously radical. With a possible reference to the Soviet Union, Lewis claimed "we have learned from the past half-century that there are practical

\footnotetext{
${ }^{17}$ Cy Gonick, "Backgrounders for the National Conference," Waffle News, July 1970, CCF/NDP Fonds MG 28 IV-I, vol. 446, file 18.

${ }^{18}$ John Bullen, "The Ontario Waffle and the Struggle for an Independent Socialist Canada: Conflict Within the NDP," Canadian Historical Review 64, no. 2 (June 1983), 202.

${ }^{19}$ Laxer was initially viewed as an unconventional choice to lead the Waffle because Watkins and Manitoba MLA Cy Gonick, who declined to run, were better known.

20 “David Lewis News Release, 28 Jan. 1971," CCF/NDP Fonds MG 28 IV-I, vol. 446, file 24.
} 
problems with the management of publicly-owned industry, [and] of democratizing its management and control ... there will, for a long time to come, if not forever, be a large and important private sector in the economy." 21 It was clear that Lewis did not want the NDP to adopt left nationalist measures.

Lewis hoped that, as in 1969, the party would support a more moderate position on economic nationalism. ${ }^{22}$ However, in private NDP leaders were concerned with the growing influence of the Waffle and the rise in support for its political agenda. Plans were drawn up to ensure that anti-Waffle delegates were present on the convention floor during critical debates. Since many of them were labour delegates who had other commitments, the party had to take steps to ensure they would stay for crucial votes, and this gave credence to the Waffle's later claim that Laxer would have won the leadership if it were not for the labour vote. The party establishment could not afford a repeat of 1969, when the Waffle seized control of the convention agenda.

As a result of Laxer's and the Waffle's efforts, left nationalism emerged as the most significant issue in the leadership race, with the leadership candidates using their positions on the subject as the primary means of jockeying for support. John Harney, the former provincial secretary for the Ontario NDP, initially wanted to position himself as the most left-wing candidate in the race by advancing a socialist and populist agenda. On nationalism, Harney announced that his position would be similar to the Ontario NDP's recently adopted Waffle-sponsored position on

21 “David Lewis News Release."

22 Ibid. 
nationalizing the energy resource sector. But he did not endorse the Waffle Manifesto. The Globe and Mail's Lewis Seale noted that as a result of this middle ground approach, Harney's campaign did gain traction, especially since the debate on economic nationalism was polarized between the moderation of David Lewis and the radicalism of James Laxer. Frank Howard, according to Seale, appeared to have no reason for entering the leadership race other than to voice his strong opposition to the Waffle group, which he saw as "out of touch with the realities of politics and common sense." 23 Lewis, Harney, and Howard may not have been in favour of a comprehensive nationalization program, but their campaigns demonstrated an acknowledgment that economic nationalism, left or moderate, was the major political issue within the party.

Leadership contender Ed Broadbent also attempted to navigate a middle ground between the Laxer and Lewis camps. Broadbent initially expressed support for Watkins' launch of the Waffle Manifesto but withdrew his support before the 1969 policy convention. In 1971 he positioned himself as the compromise candidate on nationalism, hoping to attract supporters from both the Lewis and Laxer camps. Although he admitted that he did not support the Waffle policy agenda, he was careful not to alienate Laxer's supporters, declining to denounce the group, and refusing to join up with Harney, Howard and Lewis in a common anti-Waffle front. Broadbent claimed that he welcomed the rigorous policy debate Laxer and the

23 "Five Seek the Leadership, but who will win the NDP?" Globe and Mail, Saturday, April 17, 1971. 
Waffle brought and denounced Lewis and Howard's strong attacks on the Waffle, arguing that their tactics could lead to an "internal war that could split the party." 24

Broadbent's middle-ground approach was indicated by his position on nationalization and natural resources. He rejected the Waffle's proposal to nationalize corporations engaged in manufacturing, resources, finance, transportation, and commodity distribution. However, Broadbent recognized the need to address the problem of the dominance of multinational corporations in the Canadian resource sector, agreeing with Mel Watkins' assertion that it hurt research and the development of secondary industries. In this regard, he differed from Lewis, Harney, and Howard in calling for the government to take over the petroleum industry for the "sake of research and secondary industry." 25 Broadbent's support for some economic nationalist positions demonstrated that Laxer and the Waffle had succeeded in putting left nationalism at the front of the agenda at the 1971 NDP convention, even if it was limited to a consensus that government intervention was necessary for the resource sector.

Watkins was not interested in supporting moderate approaches to the nationalist issue. He actively supported Laxer's leadership campaign. Watkins wrote a brief outline of the Waffle's aims that portrayed the group as a radical socialist and populist movement that was unique to Canadian politics. Watkins claimed the Waffle had enjoyed positive momentum since its inception, citing the strong third place showing of their candidate Don Mitchell in the July 1970 Saskatchewan

24 "Five Seek the Leadership."

25 Ibid. 
leadership race and what he characterized as the "overwhelming endorsation of the Waffle agenda" by delegates to the Ontario NDP convention in October $1970 .{ }^{26}$

Watkins also believed the Waffle was in touch with trends in Canadian politics. Evidence of this was the populist "grassroots ferment against the Americanization of the country and its institutions," which extended into culture, the media, and education. The Waffle represented "the first time in Canadian history this Americanization ran into widespread and vocal resistance." ${ }^{27}$ He identified the New Nationalists active in the CIC as concerned with preserving Canadian capitalism under threat from American dependency. The nationalist rhetoric in the recent Ontario Progressive Conservative party leadership race, and the Trudeau government's embrace of a Canada Development Corporation were also cited as evidence of nationalism catching on in the establishment capitalist parties. ${ }^{28}$

Watkins described Laxer's and the Waffle's left nationalist agenda in populist terms. He claimed it acted "in the name of building communities where people should control their own lives." For Watkins, a significant development in Canadian politics was the willingness of many Canadians such as the poor, minority groups, students, women, and workers, to look to extra-parliamentary activity collectively to demand changes and put "real democratization back on the agenda of politics." 29 Watkins also stressed the Waffle's extra-parliamentary activity and popular support beyond the convention hall. Examples of Waffle action highlighted by Watkins

\footnotetext{
${ }^{26}$ Mel Watkins, "James Laxer for NDP National Leader," CCF/NDP Fonds MG 28 IV-I, vol. 404, file 3.

27 Watkins, "James Laxer for NDP National Leader."

28 Ibid.

${ }^{29}$ Ibid.
} 
included organizing demonstrations in major cities against the continental energy deal, working with the militant members of the National Farmers Union, rallies against the War Measures Act to demonstrate support for the Members of Parliament who opposed it, and protesting the American take-over of Ryerson Press. Looking ahead to the task at hand, Watkins employed traditional socialist language, claiming "Jerusalem will not be built in a day." Waffle and NDP members must work to drive the "rising wave" of nationalism and engage in the task of creating "independence and socialism." 30 Watkins portrayed the Waffle as a movement for independence, socialism, and democracy, one that would form the basis of a reformed NDP and Canadian leftist politics leading into the 1970s.

Laxer's campaign often stressed the populist and socialist dimensions of the Waffle's policies, arguing they were the only way to deal with Canada's "crisis of capitalism," which brought worker misery, economic stagnation, and Americanization. Laxer was unequivocal in his beliefs and message: bring socialism to Canada, and the Americanization problem would disappear. He wanted NDP members to understand that without socialism, there could be no independence. Laxer was convinced that the NDP should stand for a firm socialist agenda and pointed to the party's lacklustre performance since its founding in 1961 as evidence that more needed to be done to engage working-class Canadians. He called for the party to stop pursuing a moderate agenda for fear of losing votes and instead offer

${ }^{30}$ Watkins, "James Laxer for NDP National Leader." 
an agenda that differed from the Liberals' and Progressive Conservatives' "corporatism." 31

Laxer claimed that extra-parliamentary activity was crucial to building support for his agenda, arguing that the NDP continued to fail because it subscribed to the ways and means of the "capitalist parties." ${ }^{2}$ As a result of the party's timidity, Laxer believed that critical segments of the electorate, such as the youth, poor, and immigrants were alienated from politics. A winning coalition could only be created if those non-voting groups were convinced to support a leftist agenda. He declared that a Laxer-led NDP would finally put aside fears of socialism and advocate a Canada in which the people owned the primary industries of the country and democratically decided what industry would produce. Speaking to all members of the party, he wrote, "never before has this country needed socialism so badly ... let us change the nature of our party's activity so that we can put forward a socialist program that really will result in a transfer of power in Canada." 33

Laxer issued a press release to respond to the attacks levelled against him and the Waffle by David Lewis and Frank Howard. On Lewis' charge that the Waffle was acting as a separate party and not in the NDP's interests, Laxer claimed that the Waffle had been open to all party members. He stressed that his campaign was populist by stressing that the writing of the Waffle resolutions involved hundreds of members and led to debates that had reinvigorated interest in the party. Laxer also

\footnotetext{
${ }^{31}$ James Laxer, "What the Waffle's All About," Waffle News, 3, CCF/NDP fonds MG 28 IV-I, vol. 404, file 3.

32 Ibid.

33 Ibid.
} 
refuted the accusation that the Waffle actively supported Quebec sovereignty and sought an alliance with the Parti Québécois, arguing that rational people must accept that there were differences between English and French Canada that needed to be addressed and recognized in the constitution. Laxer argued that Quebec sovereignists must be engaged so they could come to understand the more significant threat of American domination and allow the federal government to take steps to address the situation.

Laxer was sympathetic to the Quebec sovereignty movement, having studied the writings of French Canadian nationalist Henri Bourassa in graduate school. Waffle supporter Patricia Smart recalled how Laxer told her that "he got his concern for nationalism, and idea for what a nation is, from Quebec." 34 Laxer also pushed for the inclusion of a lengthy statement in the Waffle Manifesto supporting the Quebec's national self-determination. ${ }^{35}$ He firmly believed that English Canadian and FrenchCanadian nationalists could put aside their differences and arrive at a common cause of resisting American domination. Laxer wanted to unify French and English Canadian left nationalists in resisting American imperialism and he insisted that an independent Quebec would have the same problems with American branch plants and investment. ${ }^{36}$ Earlier in March 1970, Laxer gave a speech at the University of Toronto, titled “English Canada and Quebec." In it he stated that Canadian federalism had disadvantaged both French and English Canada because it "has been

\footnotetext{
34 Patricia Smart, “The Waffle and Quebec," Studies in Canadian Political Economy 32 (1990), 197-8.

35 Roberta Lexier, "Two Nations in Canada: The New Democratic Party, the Waffle Movement, and Nationalism in Quebec," British Journal of Canadian Studies 30 (2017), 8.

36 Ibid.
} 
an instrument of Americanization." Laxer argued that a new federal arrangement was needed that recognized Quebec's distinctiveness in order to ensure the two nations' unity in the "anti-imperialist struggle." Success in this endeavour was premised on "the willingness of English Canadians to struggle themselves for an end to national inequality for French Canada." 37 Ultimately, however, left nationalists in the Quebec sovereignty movement, while reading the same texts and possessing similar views of capitalism, arrived at a different conclusion. While the Quebec left nationalists agreed that "the fundamental threat was external," that threat was not the United States, but English Canada. ${ }^{38}$

Despite their Quebec counterparts' lack of enthusiasm for their cause, English Canadian left nationalists maintained their support for Quebec selfdetermination, but ultimately believed English and French Canadians were stronger together. The Waffle Manifesto recognized the "existence of two nations within Canada, each with its own language, culture and aspiration," and believed that "an English Canada concerned with its own national survival would create common aspirations that would help tie the two nations together once more." 39 While Laxer was instrumental in shaping the Waffle's position on Quebec nationalism, Watkins was also supportive of recognizing the existence of a French Canadian nation. He argued that any English Canadian calling themselves a nationalist must accept French Canadian rights. Watkins also believed that the NDP would benefit by

\footnotetext{
37 James Laxer, "English Canada and Quebec," 7 March 1970, CCF/NDP Fonds MG28 IV-I, vol. 446, file 3.

38 "Laxer Press Release," February 21, 1971, CCF/NDP Fonds MG28 IV-I, vol. 402, file 3.

39 "The Manifesto for an Independent Socialist Canada."
} 
supporting more autonomy for Quebec as it would improve the party's electoral performance in the province. ${ }^{40}$ For English Canadian left nationalists it was hypocritical to ignore the existence of a separate French Canadian nation and deny it self-determination. Watkins and Laxer's immediate concern, however, was bolstering the cause of English Canadian left nationalism against its opponents in the NDP. ${ }^{41}$

The strong showing by Laxer in the leadership race demonstrated that the Waffle had significant support among party members, despite the controversies over left nationalism, and accusations of support for anti-Americanism and Quebec sovereignty. Lewis was denied the crushing victory he needed to finally end the Waffle as a significant force. Laxer was not expected to win the leadership because the vast majority of the five-hundred labour delegates were assumed to have voted for David Lewis. ${ }^{42}$ However, far from a resounding victory on the first ballot, it took four ballots for Lewis to secure victory with Laxer holding a strong second place showing throughout, one-thousand forty-six for Lewis and six-hundred twelve for Laxer on the fourth ballot. ${ }^{43}$ Laxer's support from delegates, between thirty and forty per cent, was consistent with the level of support for Waffle resolutions at the

\footnotetext{
${ }^{40}$ Lexier, "Two Nations in Canada," 9.

${ }^{41}$ The NDP was distracted by Laxer and the Waffle's support for Quebec's national selfdetermination. The party, already having struggled with the issue in the 1960 s, had to contend with the controversy that erupted from the Waffle's acceptance of a separate English and French Canada and support for the right of Quebeckers to determine their future in Canada. The party leadership was angered by the Waffle's resolution submitted to the 1971 convention calling for the party to recognize Quebec's self-determination and the media attention it received. Lexier, "Two Nations in Canada," 12.

${ }^{42}$ Bullen "The Ontario Waffle," 205.

${ }^{43}$ Results of the ballots: First ballot: Lewis 661, Laxer 378, Harney 299, Broadbent 236, Howard 124. Second Ballot: Lewis 715, Laxer 407, Harney 347, Broadbent 223. Third Ballot: Lewis 742, Laxer 508, Harney 431. Fourth Ballot: Lewis 1046, Laxer 612.
} 
1969 convention..$^{44}$ The Waffle emerged from the 1971 convention with a renewed sense of purpose. Lewis became leader of a party that remained divided over the best approach to economic nationalism. However, Lewis recognized the growing populist fervour and anti-corporate sentiment in the NDP's grassroots and based the 1972 federal election campaign on attacking what he called "corporate welfare bums" (a reference to corporate subsidies). If the rivalry between the Waffle and the NDP establishment could be characterized as a battle, then the 1971 convention was effectively a draw.

Waffle supporters expressed overall satisfaction with the convention. Laxer was pleased with his second placed showing in the leadership race, claiming it made "it impossible for the left to ever again be ignored by the NDP." 45 Watkins and Laxer both acknowledged that the NDP was polarized, which they claimed was due to the growing power and influence of the Waffle. Lewis was initially conciliatory in his acceptance speech, promising to work with Laxer and the Waffle. However, in a press conference Lewis was dismissive and referred to the Waffle as a separate organization that had little value in rallying workers to the NDP cause. ${ }^{46}$ Despite their general satisfaction with the convention, Waffle members understood that their movement was still separate, and in open conflict, with the party leadership.

\footnotetext{
${ }^{44}$ John Bullen, "The Ontario Waffle," 205.

45 John Zaritsky, "The Jubilant Waffle Sees Victory in NDP Convention Defeat," Globe and Mail, April 26, 1971.

${ }^{46}$ Murray Goldblatt, "Lewis Asserts his Command, No Pandering to the Waffle," Globe and Mail, April 26, 1971.
} 
The 1971 Federal NDP Convention II: The Waffle's Policy Agenda

In addition to running a candidate for the party the leadership race, the Waffle actively sought to take control of the NDP agenda during the concurrent policy convention. The Waffle submitted several resolutions to the convention on topics ranging from economic nationalism to the Vietnam War, all of which were based on the conviction that Canada's economy was dependent on and dominated by the United States. In a pamphlet distributed to riding associations and youth clubs, titled "For an Independent Socialist Canada," the group outlined its vision for a Waffle-controlled NDP. ${ }^{47}$ The Waffle resolutions called for the NDP to work for the nationalization of the natural resource sector. ${ }^{48}$ Expressing the Waffle's desire to be a vanguard movement, the resolution also called for an immediate "public campaign of public education to mobilize the Canadian people against the sell-out of their resources." If the NDP formed government, the Waffle called for the immediate cancellation of any trade deals made by the "old parties," and the reinvestment of profits made by a publicly-owned resource sector into establishing resource processing and manufacturing industries. ${ }^{49}$

\footnotetext{
47 "For an Independent Socialist Canada: Resolutions Prepared by the Waffle Movement in the New Democratic party for the Consideration of Riding Associations, Affiliated Unions, and Youth Clubs for the Federal Convention of the New Democratic Party, Ottawa, April 1971," 1. Hereafter, "Waffle Resolutions."

48 Oil, coal, uranium, forestry, and hard metals and smelting.

${ }^{49}$ Concerns for the environment and the depletion of resources were also evident, with the Waffle calling for resource extraction undertaken primarily for the long-term needs of the country that would not "countenance methods of extraction ... which will result in the destruction of the ecological system." This reflected the concern about the depletion of Canada's natural resources by the United States and the rising environmental movement. "Waffle Resolutions," 1.
} 
Anti-imperialist sentiment was present in the Waffle resolutions. The group declared that any surplus resources must be traded "with a view to international development," and Canada should refuse to trade any resources to "rich countries that are already exploiting the world." 50 This provision on trade was the most controversial. Many members of the NDP could support the nationalization of the resource sector and the redirection of profits to creating much-needed secondary industries, but they believed that a refusal to trade Canada's vast resources with developed nations would lead to a significant trade imbalance and cause economic havoc. Waffle supporters were adamant that Canada was a colony of the American imperialist system. To address Canada's colonial status, Waffle members differentiated themselves from other nationalists by claiming that extreme measures needed to be taken to reverse colonialism and prevent Canada from becoming a willing party in American-led capitalist exploitation of underdeveloped countries.

In the Waffle's resolutions on Canada's resource sector, the group's members expressed their belief that their left nationalist program was the only method of preventing the country's continued domination by the United States. Arguing that Canada's resource industries were integrated into the American industrial system, the Waffle attacked the exploitation of Canada's resources by multinational corporations. A major concern was the power and influence of the multinationals. The Waffle claimed that several American-based multinationals, such as Imperial Oil (a subsidiary of Standard Oil), were so powerful that they were in fact "private

50 “Waffle Resolutions," 1. 
governments" that "wield immense power over much of the world's wealth." 51

Canada was seen as a "vast reservoir of untapped resources" by these large, powerful multinational corporations and radical measures were needed to secure the country's resource wealth. The Waffle also argued that the Canadian north was "America's new frontier, administered by the Canadian government as an internal colony." ${ }^{22}$ Concern for Canada's status as a resource colony or hinterland of the United States formed a central tenet of the Waffle's and wider left nationalist's political agenda.

Capitalism was the main reason for the colonial exploitation of Canada. For Canada, the continentalization of the country's resource sector to suit the needs of American economic expansion resulted in the exploitation of the country's resources. The federal government was accused of being complicit in the exploitation of Canada's raw materials needed to "match the requirements of an economic system that is hell-bent on economic expansion." American living standards could not be sustained without harnessing unsustainable amounts of the world's natural resources. Canada had also become an active participant in the exploitation, as "her living style having been Americanized, will join the Americans in raiding the resources of the Third World." 53 Without action taken to reverse the situation, Canada, a victim of dependency, would become an (un)willing agent in the exploitation of the underdeveloped world.

\footnotetext{
51 “Waffle Resolutions," 1.

52 Ibid.

53 Ibid.
} 
Concern with foreign ownership in Canada's resource sector was at the forefront of left nationalists' many anxieties about American dependency. Contrary to what the federal government claimed, the Waffle argued that most profits from raw material extraction flowed out of the country. ${ }^{54}$ Time was running out to address the situation because the Liberal government was "moving to intensify Canada's character as a resource hinterland of the United States" by working towards a continental energy deal, which would serve to deepen the problems of American dependency. ${ }^{55}$ In addition, concern was expressed at how these industries paid "scandalously low taxes," such as in the mining sector, which only paid four per cent of corporate taxes, despite making twelve per cent of profits generated by corporations in Canada.

The Waffle believed Canada's status as a resource hinterland of the United States also had significant implications for the country's foreign policy. The group argued that "resource deals with Americans place [Canada] in an even more dangerously close military alliance with Washington [since] the U.S. has come to depend on Canada not only for immense profits but also for strategic supplies in maintaining the military power on which Americans depend for their control of much of the globe." 56 International Nickel (INCO) was singled out for supplying the United States with most of its nickel, and fueling the American "war machine." ${ }^{57}$ The Americans regarded Canada as a safe repository of strategic resources for the

\footnotetext{
54 The pamphlet cited statistics claiming that non-Canadian enterprises owned $99.9 \%$ of oil refining, $82.6 \%$ of the oil and gas wells, and $84.9 \%$ of primary metal smelting. It was not specified how much was American.

55 "Waffle Resolutions," 2.

${ }^{56}$ Ibid., 3.

${ }^{57}$ Ibid.
} 
American military, proof for the Waffle of Canada's colonial status.. While the resource sector was the focal point of its anti-imperialist agenda, the Waffle argued that, to free Canada entirely from its "colonial status," Canada must bring all sectors of the economy into public ownership.

When introducing the resolutions on public ownership, Waffle members used populist language and described themselves as "democratic socialists," challenging the NDP to become a truly left-wing party based on a commitment to implement a fully socialist economy. The Waffle was unequivocal in its condemnation of the world capitalist system. The resolution on public ownership was a declaration of the Waffle's socialist aspirations and anti-imperialist worldview:

We live in a country and a world dominated by huge national and multinational corporations. They have exploited working people and shattered the economic life of rural communities. They have polluted our environment to the point where life is imperilled. They have pillaged our natural resources, and they have dominated our political system. Increasingly, they threaten the very sovereignty of our nation. ${ }^{58}$

The Waffle's populist rhetoric was evident in the resolution's condemnation of the capitalist system as exploitative:

In the 'new world' created by twentieth-century 'free enterprise,' it is the profit-makers, not the people, who enjoy economic mobility, shifting their operations from one country to another in search of cheap labour, natural tax conditions, and security from worker demands. Many of the industrial 'landlords' of the Canadian economy are absentee landlords, with remote head offices that protect them from the anger of thousands of Canadian workers whose jobs are disappearing daily. The Canadian labour force has become a reserve labour force, to be hired when the continental economy is thriving, and the first to be fired when the profit conditions take a downturn. 59

58 "Waffle Resolutions," 7.

${ }^{59}$ Ibid. 
Here the Waffle rejected the moderate reformist approach taken by the NDP, which sought simply to mitigate the adverse effects of capitalism. Instead, the whole capitalist system was written off. It needed to be replaced outright.

For the Waffle group, the agenda of "democratic socialism," described as a combination of populist and socialist policies, was a "radical alterative" to "the shambles of free enterprise" and "the colonization of Canada by American corporations." 60 Their agenda meant freedom from unemployment, consumerism, and the cultural, political, and economic domination of American capitalism. This alternative was a commitment to the "democratic ownership and control" of all major economic institutions. To win delegate support, the Waffle argued that only democratic socialism would allow the implementation of policy goals such as income redistribution, rational economic planning, and workers' rights. Multinational corporations were inherently anti-democratic since their corporate structure was based on plans for one industry across many countries, where socialism planned for "many industries within a single country in the most democratic fashion imaginable." 61 To counter claims that they were adherents to "Soviet-style socialism," Waffle members envisioned a socialist Canada devoid of Soviet-style planning committees imposing centralized “five-year plans." Instead, decision-making would be made democratic through autonomous communities and workers organizations. Adopting a democratic socialist system was crucial to ensuring Canada's long-term economic prosperity and political viability because it

60 “Waffle Resolutions," 8.

${ }^{61}$ Ibid. 
offered the best way to take control of the resource sector and redistribute the wealth to all regions of the country and preserve it for future generations. ${ }^{62}$ Populist rhetoric combined with traditional socialist policies characterized the Waffle's agenda regarding ownership of the economy.

The Waffle agenda of democracy and nationalization was promoted as the best means of countering American domination of the Canadian economy. ${ }^{63}$ The Waffle's resolutions called for the NDP to commit itself to the "immediate nationalization of resource industries and financial institutions, including banks and trust companies, [as] these areas are the key to breaking corporate power in Canada." Profit generated from the control of this sector would be directed to creating secondary industries that would provide much-needed investment and employment in hinterland areas such as northern Ontario and Quebec, and the Maritimes. ${ }^{64}$ The Waffle envisioned a Canadian political economy where major economic activity was controlled by the state through public ownership of all major corporations in the manufacturing, resources, financial, transportation, and commodity distribution sectors. These nationalized corporations would be compensated through long-term low-interest bonds, but those who resisted would be expropriated. Worker's councils were proposed as a means to ensure the democratic nature of the new economy and existing crown corporations would be reorganized to permit democratization.

62 "Waffle Resolutions," 8

63 Ibid., 10.

${ }^{64}$ Ibid. 
As was the case in 1969, the NDP's moderate wing did not support the Waffle's agenda, despite the Waffle's populist rhetoric of democratization. It is likely that the Waffle promoted its economic policies as a part of a populist agenda as a means of drawing attention away from their anti-imperialist rhetoric. However, the group went too far in its call for full nationalization of the Canadian economy, including the banking sector. Leftists who might have been receptive to the Waffle's democratization agenda or populist rhetoric did not want to adopt economic policies that they saw as similar to those found in communist economies. David Lewis had said as much when he accused the Waffle of supporting communism. The Waffle understood that the NDP was a not a party of democratic socialism, populism, or left nationalism, but they underestimated the level of hostility to their agenda and the coordinated attack levelled against Laxer and Waffle-supporting delegates.

The 1971 Federal NDP Convention III: Opposition to the Left Nationalist Agenda

In 1969 the NDP leadership had been mostly unprepared for the arrival of the Waffle and lost control of the policy agenda, but two years later the party put in place measures to ensure a more organized response to the group. ${ }^{65}$ Vehement Waffle detractor Desmond Morton was a supporter of David Lewis and an Ontario delegate to the convention and organized the NDP Now group to counter the Waffle's efforts on the policy resolution floor. ${ }^{66}$ Morton had been recruited by the

65 Morton quoted in Harold Greer, "Beating the Waffle," Winnipeg Free Press, April 20, 1971

${ }^{66}$ John Bullen, "The Ontario Waffle," 203. 
Ontario NDP to "clean up the radical policy mess," in the words of the leftist magazine Last Post, after their convention in October $1970 .{ }^{67}$ In his party establishment endorsed pamphlet, "NDP Now: The Case for a Majority Party of the Democratic Left," Morton did not mention the Waffle by name but denounced "rhetorical radicals" who wanted an "NDP that is strident, sectarian, and impotent." He also rejected Waffle policies on public ownership, economic nationalism, Quebec separation, and confrontation politics and extra-parliamentary activity. Speaking for the moderates, Morton claimed that many Canadians had "common sense doubt" that nationalization of industry would be beneficial, as it would transfer economic control from "vast, faceless private corporations to a vast, faceless public corporation." Morton countered the Waffle's rejection of reliance on "the liberal parliamentary concept" that aggravates "class conflict," with his own position that the party's role "lies within the democratic institutions at every level of the Canadian government." 68 Morton was clear that the NDP should not expend effort on a left nationalist agenda.

Two factions had clearly emerged in the NDP: a left nationalist group that supported the Waffle and the Laxer campaign, and another, represented by Morton and Lewis, that wanted to maintain the NDP as a moderate social democratic party. Both sides understood that, in the struggle between the camps, success would be measured by the position that the NDP adopted on economic nationalism. At a Steelworker's political conference in Hamilton on February 28, Morton intensified

\footnotetext{
67 "Spring Cleaning: How Stephen Lewis Gave up Wellington Boots, the Waffle, the NDY, and Grew Wiser in his Years," Last Post, April-May 1971, 34.

${ }^{68}$ Morton quoted in Harold Greer, "Beating the Waffle," Winnipeg Free Press, April 20, 1971.
} 
his attack on the Waffle, describing it as neither trendy nor radical, lacking in substance beyond calling for more nationalization, and possessing a tone that was "full of bitter anti-Americanism." ${ }^{69} \mathrm{He}$ urged his audience to reject the Waffle outright if the party was to have any hope of making a serious bid for power. The NDP was at a "crossroads," said Morton. In his view, the party could become a major force in the 1970s by taking the lead of positive political change that addressed the threat of American economic dominance with sensible policies. Or it could be consumed by infighting.

For Morton, debating Waffle policies was unnecessary because he incorrectly believed they promoted an old, authoritarian brand of socialism. Repeating the Lewis camp's refrain, he claimed the NDP in contrast offered "common-sense policies" that met the "threat of American domination in ways the vast mass of Canadians can understand." Morton argued that the Waffle's policies belonged in the 1930s, describing them as promoters of a "Bonnie and Clyde style of socialism," and, "the voices may be young, but they sound ancient, as though no one ... has learned anything at all since the Depression." 70 Morton described the Waffle as primarily a youth movement and was dismissive of its relevance to the point of being contemptuous of youth engagement in politics. He argued that it was "politically stupid" to indulge youth if it "turns off hard-working, sensible people with

\footnotetext{
${ }^{69}$ Desmond Morton, "The Waffle Within the Ontario New Democratic Party," Speech to a Steelworker's Political Conference, Hamilton, Sunday, February 28, 1971, 1.

${ }^{70}$ Ibid.
} 
mortgages, time-payments, and a decent concern for a better political deal in this country and their children."71

Morton's strongest denunciation came when he condemned the Waffle's American New Left roots. He was contradicting himself because the point of the New Left was to provide an alternative to the Old Left that Morton believed the Waffle represented. Nevertheless, he accused the Waffle of being ignorant of the history of the Canadian left and using the guise of nationalism to import "discredited" American leftism into the NDP. He called the Waffle "the most massive Americanizing force in the history of our movement, working flat out to impose the language and the tactics [of the New Left] which have left American socialism as a shattered, wholly irrelevant force. There is [not a] single ...Waffle idea, from women's lib[eration] to the slogan of Yankee imperialism, which has not been imported ... from the United States." ${ }^{\prime 2}$ The Waffle was an irrelevant distraction.

Morton and the NDP Now group used the Waffle's tactic of gaining positions on the NDP's policy committees that determined which proposals reached the convention floor. The strategy was to stop the Waffle resolutions before they could cause a damaging debate among delegates and throw the convention into the disarray experienced in 1969. Of the eleven resolutions submitted by the Waffle to the convention, only one made it to the convention floor. Resolutions on agriculture and extra-parliamentary activity were stopped at the committee stage, and a resolution on nationalization of the oil and gas industry was rewritten so that it

\footnotetext{
${ }^{71}$ Morton, "The Waffle Within the Ontario New Democratic Party," 3.

72 Ibid., 5-6.
} 
advocated public ownership as one possible option for state intervention in the sector. ${ }^{73}$ Delegates defeated a resolution on the Vietnam War that made it to the convention floor unaltered.

Delegates rejected the Waffle positions and endorsed moderate-sponsored resolutions that sought to curb the influence of multinational corporations and chart an independent course for Canada's foreign policy. On public ownership, delegates adopted a resolution recognizing that corporations, many of which were multinational, "dominated most of our other institutions: political, cultural, social, and educational, and moulds values and structures of our society ... [making] decisions that affect the lives of thousands of people." This was hardly a controversial statement for a party on the left of the political spectrum, and for Waffle delegates, it was nothing less than stating the obvious. There was a minor acknowledgment of the nationalist movement, however, with the declaration that the "old-time" parties (Liberals and Progressive Conservatives) had done little to mitigate the control of corporations over people's lives, a situation that was "aggravated by the high level of foreign ownership." 74

Delegates were denied an opportunity to vote on measures that confronted the issue of American dependency with socialist measures. Absent was any mention of the United States or its domination of Canada. Rather than calling for the nationalization of key sectors of the economy and the transformation of Canada into a socialist economic system, the resolution called for measures that would promote

\footnotetext{
73 Bullen, “The Ontario Waffle,” 204.

74 "Public Ownership," in Resolutions of the New Democratic Party Sixth Federal Convention, 4, CCF/NDP Fonds MG 28 IV-I, vol. 402, file 13.
} 
"the expansion of public and cooperative ownership."75 Delegates who supported this moderate agenda hoped that a minor expansion of public ownership would reduce the concentration of economic power in the hands of the business community and ensure the development of industries vital to the future of an economy that neither foreign or domestic private enterprise had fostered. ${ }^{76}$ While delegates supported a resolution calling for the halting, but not reversal, of "rapid foreign takeovers," no specifics were offered. Waffle delegates were understandably disappointed with this moderate stance on public ownership.

While the position on public ownership of the economy adopted by delegates was similar in scope to that of the Liberals, the convention differentiated itself from the Trudeau government on the issues of foreign aid, the United Nations, and the war in Vietnam. A resolution on foreign aid called for an increase in the aid budget to equal one per cent of the gross national product and declared that "aid programs are often designated to enhance the economic interests of the donor rather than meet the needs of the recipients." The NDP reaffirmed its opposition to conventional Cold War foreign policy, with delegates approving a resolution that restated the party's belief that the only long-term basis for world peace "lies in an international order based on law and social justice." 77 Without mentioning the United States by name, the resolution rejected bipolar international politics, stating, "we cannot accept [that] the ordering of world affairs should be determined solely by the

\footnotetext{
75 "Public Ownership," 4.

76 This proposition on public ownership was not radical since it was effectively a call for the maintenance of the status quo. The Canadian state, at the federal and provincial level, had for decades been intervening in sectors that were not sufficiently developed by private enterprise by creating Crown Corporations.

77 "International Affairs," in Resolutions of the New Democratic Party Sixth Federal Convention, 6.
} 
unilateral actions of nation-states in general and the superpowers in particular."78 Delegates also made a point of expressing support for decolonization movements and condemned Portugal's military action against liberation movements in their African colonies: ${ }^{79}$ "international order cannot consort with oppression and exploitation of people by colonial regimes." 80 This anti-imperialist sentiment was endorsed by delegates when directed at Portugal and South Africa, but not against the United States. Other than resolutions addressing the war in Vietnam, the moderate wing of the NDP was unwilling explicitly to condemn American foreign policy.

The NDP's most significant foreign policy positions at the 1971 convention were the ones about the war in Vietnam, which reflected anti-imperialist sentiment. However, this was not an indication of support for left nationalism. Official NDP opposition to the Vietnam War was rooted in the party's Social Gospel pacifist roots, rather than in the Marxist critique of American-led global politics advocated by the Waffle group. The NDP expressed solidarity with Americans opposing the war, referring to a "feeling of collective guilt on the part of the American people who have been brought to the stark realization that blame for the conduct of their inexcusable

\footnotetext{
${ }^{78}$ The NDP was clear that the United Nations was their preferred agent for world peace, declaring that "an NDP government will, therefore, work towards a strengthening of the United Nations and World Court. It will support the establishment of a permanent United Nations Peacekeeping Force and will commit the Canadian Armed Forces to such a body and actively work to strengthen the technical agencies of the United Nations, [and] fully accept the principle of Universal [UN] Membership." Ibid.

${ }^{79}$ Portugal undertook simultaneous military action against decolonization movements in its African colonies of Guinea and Cape Verde Islands, Angola, and Mozambique. The NDP was critical of NATO for allowing Portugal to join NATO because of its wars in the colonies. "International Affairs," 6. ${ }^{80}$ The NDP was responding to agitation, mostly from the left, and condemned the system of white minority rule (Apartheid) in South Africa and declared opposition to newly independent Rhodesia's military action to suppress the black liberation movement. Ibid.
} 
war and its inhumane results attaches not only to active participants but also those who have remained silent in the full knowledge of the inherent crime in the war itself." 81 The resolution concentrated on opposing the war on humanitarian grounds by criticizing the federal government for not acting on Canadians' opposition to the war and urged Ottawa to adopt the strong condemnation of the war by international religious groups ${ }^{82}$ who accused the Nixon administration of "a total lack of proportion between the ends sought and means used in Vietnam, and of deliberately closing their eyes to the almost incalculable human suffering which has resulted." 83 The official party line on Vietnam reflected the NDP's traditional views on foreign policy and avoided the Waffle's condemnation of capitalist exploitation and American imperialism.

The party establishment-supported resolutions dealing with natural resources emulated the Waffle's stance while avoiding left nationalist language. This indicated that left nationalists had partial success in influencing the party's agenda, despite the outright rejection of their sponsored resolutions at the committee stage. The resolution on natural resources recognized that the sector was characterized by “almost complete" foreign ownership. Countering claims that Canada needed foreign

\footnotetext{
81 "South East Asia," in Resolutions of the New Democratic Party Sixth Federal Convention, 8. 82 The groups listed were Christian Century, Christianity and Crisis, the National Catholic Reporter, and the Catholic Commonwealth.

83 Primarily focused on humanitarianism, these Christian aid groups were firm in their condemnation of the war in Vietnam. "We accuse the present administration of cruel deception in claiming to be 'winding down' the war through troop withdrawals while shifting the death and bloodshed to other people, caring only for American casualties, uprooting Asians in the path of American policy, proclaiming that airpower will know no limitations except the final restraint of avoiding nuclear bombing... [and the] absurd inconsistency of those agents of power who piously preach against isolating the U.S. from the moral judgements of the community of nations. The real isolationism we must fear is Americans throwing its [sic] weight around in the world, seeking to shape the world's destiny without invitation or consent." "South East Asia," 8.
} 
investment to ensure prosperity, the resolution tied Canada's high unemployment rate to a branch-plant economy based "almost exclusively on exploitation and export of raw materials." ${ }^{\prime 84}$ Despite the left nationalist overtones, the resolution took a moderate stance when calling for increased public ownership and avoided nationalization and socialism. The resolution stated that the NDP believed that Canada's natural resources should be managed in the long-term interests of Canadians. The country's resources must be used to create a highly developed processing and manufacturing sector, rather than be the source of raw materials for other nations. The United States, or the American empire, was not mentioned. Instead, the neutral term "other nations" was employed. ${ }^{85}$ Adding to the ambiguity of the resolution, it endorsed the expansion of public ownership in the oil and gas sector, a position long advocated by left nationalists.

The NDP leadership wanted moderate economic nationalism to be the theme of the convention. A resolution endorsed by the party establishment called for the creation of a publicly-owned Canada Development Corporation and legislation to protect the environment and address unresolved Indigenous ${ }^{86}$ land claims in future natural resource development. While not endorsing the Waffle's position of the complete public ownership of all major corporations, the resolution offered a compromise. It called for the creation of a "socialist plan for Canadian resource development that will determine how much of our resources are genuinely surplus

\footnotetext{
84 "Natural Resources," in Resolutions of the New Democratic Party Sixth Federal Convention, 9. 85 Ibid.

86 The terms used were "Indian and Eskimo."
} 
to Canadians needs." ${ }^{87}$ The resolution envisioned "worldwide trading relationships in surplus resources with a view to international development and recognizing that Canada's economic freedom is now inhibited by existing trade patterns which are not controlled by the Canadian people." The resolution also called for an NDP government to seek the establishment of "much greater diversity in our patterns of trade so that greater options and flexibility would be available to us." ${ }^{88}$ Public ownership of the resource sector would be pursued, without expressing the radicalism of the Waffle's propositions. The moderate wing of the NDP remained in control of the party.

\section{Left Nationalist Introspection}

In the aftermath of the failed bid to take control of the leadership of the NDP, the Waffle group turned to efforts to solidify its base of support within the party, organize extra-parliamentary action, and revaluate its agenda. Waffle activists produced a series of discussion papers to interrogate the reasons for the group's inability to win majority support for its agenda at the 1969 and 1971 conventions. In a joint letter titled "The Waffle and the NDP: Disappearing from Within," activists described the Waffle as a "anti-imperialist grouping within the NDP." The Waffle was portrayed as advancing a political program that was significantly different from that of the NDP. The party was not socialist because it was actually "antithetical" to the NDP's reformist agenda. Nor was the NDP anti-imperialist because of its close

87 "Natural Resources."

${ }^{88}$ Ibid. 
ties to the American-controlled unions. The letter claimed that the Waffle failed to take over the party because it never operated independently of it. While stopping short of recommending a break from the NDP, the letter advocated more extraparliamentary activity away from the party to avoid "disappearing from within." 89

Mel Watkins, Gordon Laxer (James Laxer's brother), and others proposed an alternative strategy in a letter to the Waffle membership. In their view, the Waffle needed to intensify its efforts within the NDP to achieve its goal of creating a socialist party. "Our essential task is to build a mass socialist movement in Canada. At the recent time, no such movement exists. Of the various political forces that a significant number of workers, farmers, and intellectuals support, the most progressive, despite its obvious shortcomings, is the NDP." To that end, they proposed that only NDP members be allowed to vote at Waffle meetings and take positions of leadership in the group. ${ }^{90}$ The letter also urged Waffle members to participate in the upcoming federal and provincial elections. This was likely an attempt by Waffle leaders to prevent the movement from dissolving. Waffle activists were undoubtedly demoralized after Laxer's defeat in the leadership race.

Other activists wanted the Waffle to develop a more socialist ideology and strategy while maintaining close ties to the NDP. In "A Socialist Strategy for the Waffle," Waffle co-founder Krista Maeots (and James Laxer's wife) wanted the Waffle to renew its socialist ideology and downplay its anti-imperialism and

89 "The Waffle and the NDP: 'Disappearing from Within'," letter signed by David Aspinall, Len Chopitany, Daniel (Danny) Drache, John Lang, and Neil Keller, CCF/NDP Fonds MG 28 IV-I, vol. 446, file 11.

${ }^{90}$ Mel Watkins, Gordon Laxer, et al, "A Strategy for the Waffle," November 12, 1971, CCF/NDP Fonds MG 28 IV-I, vol. 446, file 11. 
nationalism. The Waffle was not a failure. It "advanced, not retreated in its socialism during the two and a half years of its existence ... our efforts have meant qualitative and quantitative growth for the Canadian socialist movement." She credited the Waffle with creating "a national coalition of left socialists in English Canada." Maeots believed the group's association with the NDP gave it more credibility and visibility, separating it from the other leftist vanguard parties or groups such as the League for Socialist Action. Waffle members needed to embrace their role within the NDP because the Waffle was "a socialist caucus in the NDP with a specific strategic conception of the socialist struggle within Canada." 91 Disassociation from the NDP would mean an end to the Waffle's influence as a leftist political force.

In the midst of this Waffle introspection, the NDP's leadership became alarmed at the Waffle's persistence. David Lewis and his son Stephen, were frustrated that the Waffle group did not disband and remained a major faction that enjoyed a devoted following, including many members who were openly hostile to the party leadership. The internal civil war that Ed Broadbent worried about during the leadership race threatened to break out. Luckily for the leadership, the unions maintained their substantial clout in the party. Many union leaders felt threatened by the nationalist sentiment of the Waffle movement; some labour movement veterans equated the Waffle with the Communists who attempted to infiltrate the union movement in the 1940s. ${ }^{92}$ It was in this divisive climate that the Ontario wing of the NDP established a committee to review the Waffle's position in the party and

\footnotetext{
91 Krista Maeots, "A Socialist Strategy for the Waffle," 1-2.

92 Michael S. Cross, "The Waffle or the Unions," Canadian Forum, April 1972, 3.
} 
propose recommendations to the executive council on an appropriate course of action.

Significant animosity had developed between the Waffle and union leadership. Waffle supporters routinely labelled the Canadian labour movement as under the control of American interests, with its leadership acting at the behest of its American bosses. As the 1971 leadership convention demonstrated, union delegates had stymied the Waffle's advance and many Waffle supporters blamed union delegates for having prevented Laxer from winning the leadership. Labour leaders, however, denied being agents of Americanization, or opponents of an economic nationalist agenda. Dennis McDermott, director of the Canadian unit of the United Autoworkers was a stanch opponent of the Waffle, which he described as consisting of out of touch academics who had nothing new to offer the working class other than nationalizing industry. Waffle members "draw their fat salaries for lecturing a couple hours a week and have all kinds of free time on their hands to meddle in other people's business." McDermott directed most of his anger towards Laxer, who he described as an "irresponsible academic, accountable to no-one, and an ego-tripper par excellence." 93 In response, Laxer and Watkins called McDermott's statement contemptuous and accused him of being more concerned about what his bosses in Detroit wanted than what was best for Canadian autoworkers. ${ }^{94}$

With there being little chance of the Waffle reconciling with the unions or the NDP leadership, the NDP review committee recommended that the Waffle disband,

\footnotetext{
93 Wilfred List, "Auto Union Censures Waffle for 'Interference in Affairs'," Globe and Mail, January 17, 1972.

94 Ibid.
} 
and its members be expelled. The Waffle was by committee members viewed as an insurrectionary group focussed on challenging the party leadership and violated what it meant to be a member of a political party, whatever the merits of the Waffle's politics. ${ }^{95}$ The executive voted to expel the Waffle from the party, but made a point of stating that their decision was not based on opposition to the Waffle's left nationalist policies. Waffle supporters were not convinced. Laxer strongly refuted the committee's assertion that a major purpose of the Waffle was to oppose the party's leadership structure, arguing that it hardly crossed their minds. Instead, he insisted that the Waffle was concerned with how the leadership consistently rejected socialist, populist, and nationalist resolutions from the riding associations. ${ }^{96}$ Laxer believed that the Waffle positively contributed to the intellectual development of the NDP and the party made a grave mistake in expelling the Waffle.

Laxer's defence of the Waffle's political program represented an outline of the agenda of English Canadian left nationalism. It was a left populist alternative to conventional Canadian politics and a home for anti-imperialist interpretations of Canada's political and economic relations with the United States. For Laxer, the Waffle group had more important concerns than protracted fights over party structure and leadership rules; instead, the "overwhelming purpose in the minds of those who wrote the Waffle Manifesto was to express the severe danger that the multinational corporation posed for the future of Canada." He described this threat

\footnotetext{
95 "Report from Provincial Executive, from Gordon Vichert, John Brewin and Gerald Caplan, 4, CCF/NDP Fonds MG 28 IV-I, vol. 446, file 23.

${ }^{96}$ James Laxer, "A Reply on Behalf of the Waffle," The New Democrat, May/June 1972, 3.
} 
in stark terms and argued that the overwhelming cultural, political, and economic power of the United States would destroy the Canadian nation and reduce communities to "seeking a better life for themselves as marginal northern outposts of American politics." Debates over what socialist program to adopt would not matter if the threat to Canadian independence was not addressed. Laxer believed that the NDP's preferred approach of gradualism to mitigate the worst effects of capitalism was insufficient to deal with the problem of American dependency. ${ }^{97}$ After the Waffle's expulsion, Laxer sharply criticized the NDP and suggested that its reluctance to commit to a program of Canadian independence meant that it was a failure as a leftist political force. Laxer believed that the NDP's social democratic program was meaningless and the party was "obsolete" because of its failure to realize that power must be taken from the capitalist class in order to establish a truly independent political economy. Left nationalism was necessary. Otherwise the NDP would be complicit in allowing Canada to be dominated by the United States and turned into a deindustrializing hinterland. According to Laxer, the NDP leadership had become accustomed to not being challenged, and since the 1950s (when the party was the CCF) had viewed its position as having a "monopoly on the Canadian left." 98 The Waffle's challenge to the NDP exposed the hollowness of the party's political platform.

The Waffle caught the party off guard because it represented a strong left populist challenge. Recalling the initial reaction to the Waffle in 1969, Laxer wrote

\footnotetext{
${ }^{97}$ Laxer, "A Reply on Behalf of the Waffle,"3.

98 Ibid.
} 
that "some saw [the Waffle] as a seven-day wonder of youthful enthusiasm; others saw a conspiracy [directed at the leadership]; still others wearing the glasses of the Cold War, saw it as the rebirth of the Reds they had put to rest so many years before." 99 Laxer claimed that the Waffle was the product of the new social and political developments of the 1960s that occurred in Canada and around the world. The NDP had to recognize this reality to remain relevant.

Laxer consistently claimed the Waffle was a legitimate force because it was part of the international trend of an emergent left populism based on movements led by youth, minorities and women mobilizing for democratic change. ${ }^{100}$ Laxer even optimistically claimed that the Waffle was on the right side of public opinion with its characterization of the United States as an "empire" based on "militarism abroad and racism at home." Canadians believed this, because it was a "simple fact" that the war in Vietnam and the unrest in American cities were evidence of "deep flaws in American civilization." According to Laxer, this "decade of turbulence" in the United States produced an "intellectual rebirth" of the Canadian left. The Waffle Manifesto was a direct product of the emergence of a New Left tradition in Canadian political thought, and, importantly for Laxer, it represented a "transcendence of both American style New Leftism and the tired Welfare statism to which the NDP had lapsed ... a challenge to the leadership, and a ringing declaration of left-wing Canadian nationalism [and] a program of action for the 1970s." ${ }^{101}$ Laxer did not

\footnotetext{
${ }^{99}$ Laxer, "A Reply on Behalf of the Waffle,"3.

100 The Waffle was not alone in its program of working-class radicalism; Laxer correctly pointed to similar left populist movements in France and Italy.

${ }^{101}$ James Laxer, "A Reply on Behalf of the Waffle," 4.
} 
convince his critics with these assertions. The Waffle's many detractors criticized what they regarded as its contradictory combination of socialism and nationalism and its strategy for political action.

After the Waffle

The NDP's rejection of the Waffle and its reluctance to adopt an antiimperialist or socialist program led the party's Marxist affiliated groups such as the League for Socialist Action to revaluate their relationship with the party. ${ }^{102}$ This task was conducted between 1973 and 1975, and was, according to historian Ian Angus, "the most complete discussion of the NDP ever conducted by Marxists in Canada."103 Marxists, specifically the Trotskyists led by Ross Dowson, had regularly criticized the NDP's “bourgeoise tendencies." In 1970 Dowson outlined the Trotskyists position on the NDP in a pamphlet titled Our Orientation to the NDP.104 He did not agree with the Waffle's previous attempt at taking control of the NDP and instead called for the formation of a new party that would be unequivocally socialist and Marxist. Dowson declared, "the revolution that is coming - that will place the [workers] of this country in full command over its vast resources, that will link it to the worldwide struggles of the working class and lay down the foundations of the

\footnotetext{
102 Unlike the Waffle, this relationship was unofficial. Ian Angus described the LSA as "a looselydefined group that embodied supporting the NDP in elections, encouraging radicals to join the NDP and labor unions to affiliate to it, and urging the NDP to adopt socialist policies. At various times it also meant that LSA members joined the NDP and tried to build left-wing caucuses in alliance with other left-wing critics of the NDP leadership." Ian Angus, "An Overview of the 1973-1975 NDP Discussion in the LSA/LSO," in Socialist History Project. http://www.socialisthistory.ca/Docs/CCFNDP/NDP-73-75/Overview.htm 103 Ibid.

${ }^{104}$ Later republished in 1976 after Dowson left the LSA as "The Socialist Vanguard and the NDP."
} 
new socialist order of peace and freedom — requires a party as its organizer and director." The NDP was entirely unprepared or unable to fulfill the task. Dowson wanted a new party acting as a revolutionary vanguard. This party would not be "an elitist formation of self-appointed saviours, but a party of working women and men completely dedicated to the struggle of the workers, a party of leaders of the class a combat party armed with a revolutionary program."105 Laxer's left nationalism and populism was clearly not radical enough for the Trotskyists.

Despite his dismissal of left nationalists as an "elitist formation of selfappointed saviours," Dowson's criticism of the NDP often overlapped with Laxer's. Both agreed that the NDP was reformist, not revolutionary, and worked against the interests of the workers by collaborating with capitalists and American interests such as the unions. The NDP's support for moderate economic nationalist measures, social reformism, and American-based unions was cited by both Trotskyists and Wafflers as reasons for the party's unwillingness to embrace, or hostility towards, radical change. ${ }^{106}$ By late 1973 , Wafflers and Trotskyists in the LSA were in agreement that the NDP was no longer an effective vehicle for socialist politics.

In early 1974, the Political Committee of the LSA complied a report on the prospects for further cooperation with the NDP. Of particular concern was the experience of the Waffle and whether it was a harbinger of party policy towards the LSA. The report's author, LSA activist John Steele, claimed the Waffle failed because the radicalization of the youth movement occurred without a corresponding

\footnotetext{
105 Ross Dowson, “The Socialist Vanguard and the NDP (1976)," in Socialist History Project. http://www.socialisthistory.ca/Docs/CCF-NDP/Orientation-Dowson-1970.htm 106 Dowson, "The Socialist Vanguard and the NDP."
} 
radicalization of labour. This was clearly evidenced by the labour delegates decisively voting against Laxer's leadership campaign, while party activists, many of whom were active in the New Democrat Youth, were strongly supportive. After Laxer's defeat, a majority in the LSA, with Dowson dissenting, had urged the Waffle to take a "stay and fight approach," in the hope that the labour movement would eventually be radicalized in the event of an economic crisis. ${ }^{107}$ This corresponding radicalization of youth and labour did not occur, and the Waffle movement split between those who wanted to stay within the NDP and those who decided to form a new party, the short-lived Movement for an Independent Socialist Canada.

Steele described a period of demoralization and discord among leftist activists after the Waffle's failure in 1971. This was indicated by a lack of leftist activism at the party's 1973 convention, described by Steele as "firmly under the control of the right-wing leadership," who had "attempted to give a theoretical veneer to their bankrupt social democratic ideology." 108 The Waffle's defeat meant the weakening of the NDP as a vehicle for class struggle, leading other leftists reluctantly to adopt "sectarian and ultraleft tactics, [which] preclude[ed] any possibility of their being an effective force for the construction of a class struggle current in the NDP." The fracturing of the left nationalist and Marxist movement also led to a split in the NDP's left caucus and the formation of the Revolutionary Marxist Group (RMG) ${ }^{109}$ as a breakaway from the LSA. Steele noted that NDP leader David

\footnotetext{
107 John Steele, "Our Task in the New Democratic Party Today," LSA/LSO International Bulletin, January 1974.

${ }^{108}$ Dowson, "The Socialist Vanguard and the NDP."

109 The Revolutionary Marxist group broke away from the League for Socialist Action and the NDP in 1973 shortly after the expulsion of the Waffle. This was another indication of the fracturing of left nationalism and political Marxism after 1973.
} 
Lewis' "make parliament work" agenda of supporting the minority Liberal government went largely unopposed at the party's 1973 policy convention. Steele called Lewis's initiative "disastrous" since it alienated the remaining leftists in the NDP and "broke the drive to bring the NDP to power."110 Steele was correct in his conclusions, with the Waffle's expulsion and subsequent disintegration of its successor, and the fracturing of other leftist groups, there appeared to be little possibility of advancing Marxism, left nationalism, or even populism in the NDP. Some leftists doubted the merits of using nationalism to advance a socialist agenda. In 1970, political scientist George Martell was skeptical of the validity of equating socialism and nationalism in Close the $49^{\text {th }}$ Parallel. His essay "What Can I do Now?" questioned Laxer's nationalist credentials. Martell argued that the Laxer program was futile because it would result in the importation of the values of the American New Left. He even wondered if there was a Canadian nation-state: It no longer seems likely that the Canadian nation-state can serve as a framework in which something threatening to corporate capitalism can take place. As a country, I believe we have had it. Our culture, our politics, our economy are almost entirely packaged in the US, whether by the radical left or the great corporations. It is not so much we are a colony; we are an integral part of the empire. We are Americans now. ${ }^{111}$

Martell believed that Canadian socialists should accept the fact that Canada was a part of the American empire, either as a colony or a willing partner enjoying special status, and should regard themselves as part of American New Left working to defeat the empire from within. In order to accomplish this task, the Waffle needed to

\footnotetext{
110 Steele, "Our Tasks in the New Democratic Party Today."

111 George Martell, "What Can I do Now?" in Close the 49th Parallel: The Americanization of Canada, ed. Ian Lumsden (Toronto: University of Toronto Press, 1970), 191-2.
} 
ally itself to New Left protest movements in the United States. But Laxer and other Waffle members did not view themselves as merely an extension of the American New Left. Part of the reason why they founded the Waffle was to offer a Canadian alternative to merely importing the jargon, politics and tactics of New Leftists operating in the United States. In this sense, Martell's assertion that the Waffle should absorb itself into the wider American New Left missed the point.

Leftist criticism of the Waffle was not limited to the defeatism expressed by Martell. Marxists such as Gary Teeple were also critical of the Waffle's methods and program. Teeple was disappointed that the Waffle did not fulfill its potential and remake the NDP into a truly socialist party. He agreed with the LSA's critique of the Waffle, arguing that it failed to radicalize the labour movement and gain worker support for its agenda. Writing in Capitalism and the National Question, Teeple argued that the Waffle was destined to failure as a political project because it never outlined a plan for achieving its socialist agenda or fully accepted what he saw as its Marxist outlook. However, Teeple believed that the Waffle was right to question the socialist credentials of the NDP. In his view, the NDP was not Marxist or socialist because the party's criticism of capitalism remained limited to "moralizing on the condition of the people," rather than focussing on why the working classes are "alienated or exploited." 112 He claimed that the Waffle failed to gain control of the party because it made incorrect assumptions about itself and the party it sought to take over. Teeple argued that the Waffle assumed it was a socialist movement

112 Gary Teeple, "Liberals in a Hurry," in Capitalism and the National Question in Canada, ed. Gary Teeple (Toronto: University of Toronto Press, 1972), 244. 
without fully outlining its credentials or building upon its populism. Other than a brief mention of workers being able to control the state, he pointed out that it was never explained how this would occur since there was no mention of a revolutionary struggle or achieving its goals through Parliament.

Teeple claimed that the Waffle was ultimately not a Marxist movement because of the lack of class analysis in its program. In his damning critique, Teeple characterized the Waffle as a "non-Marxist, left-wing of a social democratic party ... a group whose ideas differ in degree but not in kind from the mixed economy or state capitalism theories of the parent NDP." 113 He charged that the Waffle failed to examine the nature of the NDP or its relationship to it and chose instead to "silence its critics with presumptuous statements about the socialist NDP, its labour base, and the political impotence of the numerous mini-left groups outside the party."114 This was an unfair characterization. The Wafflers had made a serious attempt at addressing these shortcomings. The Waffle was premised on Marxist-influenced intellectual trends, such as dependency theory and anti-imperialism. Perhaps the Waffle was overly optimistic or overconfident about the NDP as a vehicle for socialism.

After its expulsion from the NDP, Waffle activists sought to address the movement's shortcomings and renewed their efforts to combine socialism with nationalism by contributing to Robert Laxer's (Canada) Ltd.: The Political Economy of Dependency (1973). Robert Laxer, James's father, was a former member of the

\footnotetext{
113 Teeple, "Liberals in a Hurry," 245.
}

114 Ibid., 246. 
Communist Party of Canada and wanted the Waffle to concentrate on advancing a Marxist and socialist agenda, rather than nationalism. Laxer attempted to address the criticism of a lack of a sophisticated Marxist framework in their left nationalism. In introducing (Canada) Ltd. he argued that the American-dominated continental economy was de-industrializing Canada and returning it to the role of "hewers of wood and drawers of water," a reference to Harold Innis's Staples Thesis. ${ }^{115}$ In response to the criticisms levelled against the Waffle by Marxists such as Gary Teeple, Robert Laxer argued that an emancipated working-class was finally in a position to create an "independent socialist society and state." $116 \mathrm{He}$ contended that the survival of Canada, and left nationalism, depended on workers' consciousness of the perils of American dependency, achieved through an agenda of left populism. The populist political movement would be based upon the workers' awareness of their status as colonized under an American empire, represented by the multinational corporation for which they worked, and the American unions of which they were members.

Robert Laxer described the 1970s as marking a crossroads for both Canada and the Canadian left and claimed that during the 1970s and 1980s Canada's future would either be pointed towards continentalism and a "final lament," or towards "socialist independentism and new birth."117 In his contribution to (Canada) Ltd., Mel Watkins arrived at a similar conclusion, arguing that only socialism could

\footnotetext{
115 Robert Laxer, "Introduction," in (Canada) Ltd.: The Political Economy of Dependency, ed. Robert Laxer (Toronto: McClelland and Stewart, 1973), 23.

116 Ibid., 24.

117 Laxer, "Introduction," 23.
} 
preserve Canada's independence. However, in a defeatist tone, he wrote, "the disintegration of Canada appears to be inevitable [and] ... the nature of Canadian corporate capitalism abets this disintegration." 118 The task ahead for left nationalists was to strengthen their socialist credentials.

Despite the efforts of the Laxers and Watkins to strengthen the left nationalism advanced by the Waffle movement, (Canada) Ltd. was met with lacklustre reviews from some left nationalists. Marxist critics such as Leo Panitch and Reginald Whitaker criticized what they claimed was its insufficient Marxism. Writing in Canadian Dimension, Panitch and Whitaker wanted a clearer acknowledgment of the Waffle's Marxist roots and a move away from nationalism. They argued that the emphasis of all the essays in Canada Ltd. should have been on Marxism, since the book was most successful when it "[emphasized] class issues over nationalist mystification." They were highly critical of the inclusion of Robin Mathews' anti-American essay, "Canadian Culture and Liberal ideology," and claimed he was not a socialist. ${ }^{119}$ Panitch and Whitaker had lost patience with left nationalism and supported the Waffle only to the extent that it was a project for socialism and a vessel for Marxism in Canada.

The opposite viewpoint was presented by philosopher and NDP activist Charles Taylor, who had been sympathetic to the Waffle in its early stages, Taylor wrote that (Canada) Ltd. offered no realistic political program, since it was overloaded with outdated Marxist dogma more suitable to an early twentieth-

\footnotetext{
118 Mel Watkins, “Contradictions and Alternatives in Canada's Future," in (Canada) Ltd., 263. 119 Leo Panitch and Reginald Whitaker, "The New Waffle from Matthews to Marx," Canadian Dimension, April 1974, 52-3.
} 
century communist agenda. He believed that a socialist agenda for the 1970 s must be free of the "pious conviction that true socialism must be Marxist."120 In contrast to the Marxist critiques of Panitch and Whitaker, Taylor argued that the Canadian left often overlooked the issue of national identity. In his view, the Waffle succeeded in making nationalism a major issue in the English Canadian left, and this was "one of the [Waffle movement's] most valuable contributions" to the independence movement. ${ }^{121}$

According to its critics, (Canada) Ltd. was neither sufficiently Marxist, nor adequately nationalist. The response to the book spoke to the fate of the Waffle's short-lived successor, the Movement for an Independent Socialist Canada (MISC). Unable to placate those who wanted to keep the nationalist cause alive and those looking to embrace Marxism as the basis of reinvigorated Canadian socialism, the MISC disbanded in 1974. New Nationalists such as Charles Taylor meanwhile reaffirmed their support for the NDP. Marxists such as Panitch and Whitaker turned to academic pursuits, focusing their attention on placing a reinvigorated Marxism into Canadian political thought. In late 1974 Watkins and Laxer were forced to leave the MISC after their leadership was challenged by newcomers who wanted to advance more radical and insurrectionary policies. Left nationalism as a political movement had come to an end.

New Nationalists remained in charge of the NDP and its political agenda. Two years prior to the 1974 disbanding of the MISC, the federal election reduced the

\footnotetext{
120 Charles Taylor, "The Canadian Dilemma," Canadian Forum, May-June 1974, 30.

121 Ibid., 31.
} 
Trudeau Liberals to minority status in Parliament, giving the NDP significant influence in policymaking. The moderate establishment was entirely in charge of the party after the expulsion of the Waffle. Evidence of the triumph of the position of Lewis and Morton was the party's response to the Liberal government's Foreign Investment Review Act (Bill C-201) introduced in May 1972. The NDP introduced several amendments to the bill, which were intended to strengthen its provisions against takeovers of Canadian businesses by foreign (mostly American) interests. The NDP amendments sought greater government involvement in research and development, which was singled out as the primary concern because of the increasing amount of foreign ownership in Canada's natural resource and manufacturing industries. NDP amendments were also directed at strengthening the bill's provisions regarding which foreign-owned corporations were subject to foreign laws (such as the American Trading with the Enemy Act). There was no call for nationalization of foreign-owned corporations; instead, the NDP advocated increased regulations to temper the effects of the growing level of foreign ownership in the resource and manufacturing sectors. ${ }^{122}$ The Liberal government accepted the NDP recommendations, ensuring that moderate economic nationalist measures would be implemented to deal with American dependency.

Broadbent remained concerned that multinational corporations did not invest in research and development outside their home country and worried Bill C201 did not go far enough to curtail the problem. In a June 1972 speech to the House

122 Ed Broadbent, "Speech, Foreign Ownership," $4^{\text {th }}$ Session, 26 ${ }^{\text {th }}$ Parliament, June 26, 1972, Ed Broadbent Fonds MG 32 C-83, vol. 12, file 2. 
of Commons, he pointed to a recent Organization for Economic Cooperation and Development (OECD) report that Canada was last in spending on research and development out of the ten leading industrial nations. Broadbent portrayed the multinational corporation as detrimental to Canada because the limited spending on research and development meant a lack of employment for those with advanced qualifications in science and engineering. Broadbent did not use his concerns as a means of justifying left nationalism. He never used any of the rhetoric employed by the Waffle when describing the ill effects of a lack of investment in research and development. Thus, left nationalism, or socialism, did not form the basis of the NDP's policy agenda pertaining to multinational corporations or foreign takeovers. In the amendments proposed to Bill C-201 by Broadbent and the NDP, there was no mention of nationalization or public ownership or replacing capitalism with democratic socialism.

Conclusion

Left nationalists challenged NDP orthodoxy and brought much needed debate to the party on how to deal with American dependency, but they did not take over its policy agenda. Despite the efforts of Laxer, Watkins, and their allies in the Waffle, the wider Canadian left did not adopt their political program, nor did left nationalists agree on a way forward after the Waffle's expulsion. Left nationalists diverged into those who wanted to advance anti-imperialism and those who wanted to concentrate on a left agenda of populism or democratic socialism. The NDP believed that its moderate economic nationalist and social democratic agenda would 
increase support at the ballot box, but, after brief success in increasing its seat count in the 1972 election, the NDP languished as a third party for the remainder of the decade. ${ }^{123}$ It lost ground in 1974 when the Trudeau government was re-elected with a majority of seats in the House of Commons.

The left nationalism expressed by the Waffle was a distinctive form of economic nationalism that was in direct contention with the moderates in the NDP. Containing elements of anti-imperialism and democratic socialist ideology, the Waffle platform was unable to satisfy the left nationalist ambition of remaking the NDP into a truly leftist party that would advance Canada's independence from American imperialism and capitalist economics. While experimenting with the politics of left populism, Laxer's leadership campaign was unable to gain the mass support it needed to defeat the party establishment or to counter the agenda of the New Nationalists.

The defeat of the Waffle and James Laxer's leadership campaign did not mark the end of the English Canadian left nationalist movement. The Waffle's populism, however, failed to overcome the entrenched power and influence of the NDP establishment and their labour allies, who were firmly of the opinion that moderate economic nationalist measures were the best course of action to arrest American dependency. Too much time and effort was expended on internal party battles and

\footnotetext{
123 The NDP's platform embraced some leftist polices, including paid maternity leave, a ban on nuclear testing, and Canada's withdrawal from NATO. The platform endorsed the public ownership of the oil and gas sector but proposed moderate measures on other economic issues such as ending direct grants to foreign corporations and introducing a screening agency to review foreign takeovers. Cy Gonick was not impressed, calling the platform and the campaigns focus on attacking "corporate welfare bums," "Liberal-lite." Alan Whitehorn, Canadian Socialism: Essays on the CCF-NDP (Toronto: Oxford University Press, 1992), 91.
} 
the Waffle was unable to galvanize broad support beyond specific segments of the party rank-and file. While the Waffle was defeated and disbanded, left nationalists continued to advocate for its anti-imperialist and social democratic ideas.

The project of remaking Canada into an independent socialist country was not limited to internal party conflict played out during conventions. While left nationalists did not gain control of a political party, they remained a significant force in academic circles as a new generation of Marxist scholars identified the cause and course of Canada's problem of political economy and American dependency. Laxer and Watkins were undaunted by the defeat of their bid to take control of the NDP and transform it into a vehicle for left nationalism and socialism. They quickly turned their attention to the politics of Canada's relations with the United States and the issue of continental energy exportation, issues that would gain increased prominence after the 1971 leadership race. 


\section{Chapter 3: \\ Confronting American Dependency and Decline, 1970-1974}

This chapter studies how English Canadian left nationalists confronted the problem of dependency in the context of American decline. While left and New Nationalists shared a concern over American dependency and decline, this chapter demonstrates the differences between the groups. Their two agendas were incompatible. Left nationalists insisted that only a revolutionary change in the Canadian political economy and relationship with the United States would liberate Canada from the American empire. In contrast, New Nationalists wanted to salvage capitalism through reform, regulation, and increasing Canadian ownership.

Radical movements such as left nationalism emerge in times of crisis. Left nationalists, in addition to their concern about Canada's economic dependence on the United States, grew increasingly alarmed at American decline. Canada, whether enjoying special status, or as a subjugated colony, remained in a semi-peripheral relationship with the American empire - or so a left nationalist would say. However, from that perspective, in the early 1970s the threat to Canada from American imperialism became less about domination and more about suffering from the illeffects of American imperial overstretch and economic decline. Left nationalists contended that only a completely new Canadian political economy and relationship with the United States would free the country from American dependency in an age of crisis. In the early 1970s English Canadian nationalist sentiment increased as the

problems associated with Canada's close political and economic association became 
evident. Left nationalists had to contend with those who did not share their views on the solutions to the problems of American dependency.

\section{American Decline and Declinist Sentiment}

Concern with American decline was widespread in the 1970s. Canadian and American leftist and liberal academics and commentators argued that the United States faced imperial overstretch because of the war in Vietnam and an economic decline indicated by a balance of payments crisis, social unrest, urban decay, and increasing competition from emerging powers such as Japan and the European Economic Community. ${ }^{1}$ Cy Gonick spoke for the left nationalists when he declared in late 1973 that "we are observing the crumbling of the American Empire." Referring to recent events such as the energy crisis and the American withdrawal from Vietnam, Gonick observed, "like England at the turn of the century, the U.S.A is fighting to remain on top of the capitalist world."2 Ominously for Canada, Gonick predicted that the United States would not go down without a fight, "to be sure, it is only the beginning and like the beasts of the forest when wounded the American giant will be fierce in its fight to stave off its inevitable demise."3

Historians and political scientists described the years from the early to mid1970s as representing one of several periods of decline in American history. ${ }^{4}$ The

\footnotetext{
${ }^{1}$ Samuel P. Huntington, “The U. S.: Decline or Renewal?" Foreign Affairs 67, no. 2 (Winter 1988-89), 76. David A. Bell, "Political Columnists Think America is in Decline, Big Surprise," New Republic, October 7, 2010 https://newrepublic.com/article/78216/america-in-decline-thomas-friedman. ${ }^{2}$ Cy Gonick, "The American Empire: The Long Descent," Canadian Dimension, November-December 1973, 16.

${ }^{3}$ Ibid.

${ }^{4}$ Declinism in the work of American commentators, political scientists, economists, and historians remained prevalent into the late 1980 s. Some examples of works that were inspired by the
} 
American political scientist Samuel P. Huntington characterized American declinist writings and the theory of declinism prevalent in the 1970s and 1980s as having three general propositions. The first contended that the United States was declining rapidly compared to other major economies, such as Japan and to a lesser extent western Europe. The second contention was that economic power was the central component of a country's strength. The third proposition, evidenced by the prolonged American military intervention in Vietnam, held that the United States' relative economic decline was primarily caused by overspending on the military, leading to "imperial overstretch." 5 While the question of whether the United States was actually suffering from imperial overstretch and relative decline is beyond the scope of this chapter, it is important to note that all Canadian nationalists shared this American concern with decline and feared Canada would suffer economically.

The writings and debates on Canadian-American relations and American dependency and decline among English Canadian nationalists reveal a diverse array of political agendas, ideologies, and movements that go beyond the Waffle movement's fight against the leadership of the NDP. Despite being a disparate group, ranging from socialists and Marxists to moderates active in the Committee

experience of the 1970s included Walter Russell Mead, Mortal Splendor (Boston: Houghton Mifflin, 1987); David P. Calleo, Beyond American Hegemony (New York: Basic Books, 1987); and Paul Kennedy, The Decline and Fall of the Great Powers: Economic Change and Military Conflict from 1500 to 2000 (New York: Random House, 1987).

${ }^{5}$ In the historiography, the declinist view was prominently advanced by Paul Kennedy who argued in his 1987 Decline and Fall of the World Powers: Economic Change and Military Conflict from 1500 to 2000, that the United States faced imperial overstretch and economic decline resulting from the strains of the Cold War made acute in the 1970s, specifically the Vietnam War and competition from emerging economic powers. Paul Kennedy, The Decline and Fall of the Great Powers: Economic Change and Military Conflict from 1500 to 2000 (New York: Random House, 1987), 534. Huntington, "The U.S.: Decline or Renewal?" 76-77. 
for an Independent Canada (CIC), the common theme among nationalists was the desire to establish a Canada with a political economy and a foreign policy that was independent. Mel Watkins described this agenda as "independentism," encompassing all those who sought to reduce Canada's economic dependence on the United States and maintain independence in foreign policy. Nationalists such as Abraham Rotstein who had leftist views but were not associated with the left nationalist cause, were also concerned with American decline and sought a middle way between the free-enterprise approach and socialism. The debates over how to implement "independentism" and solve the problem of American dependency revealed the true extent of the divide between the English Canadian left and New Nationalist strategies of confronting the problems and consequences of American imperial overstretch in the early 1970s.

Marxists who studied international relations often concentrated their attention on analysing exogenous factors that resulted in change, singling out imperialism as the primary agent. While Marxists disagreed on the meaning and consequence of imperialism, its causes were generally interpreted as the product of the need of major capitalist powers for raw materials and markets. Marxists agreed that the United States had imperialistic characteristics; its relations with other states were characterized by a core-periphery, or empire-colony, relationship. ${ }^{6}$ Canadian left-nationalists were convinced that this framework applied to the Canadian-American relationship.

${ }^{6}$ J. Paul Grayson, "Introduction," in Class, State, Ideology, and Change: Marxist Perspectives on Canada, ed. J. Paul Grayson (Toronto: Holt, Rinehart and Winston of Canada, 1980), 8. 
Left nationalists also viewed relations between world powers as driven by competition for capital accumulation that often led to upheaval. In addition to witnessing a period of decline, historians such as Daniel J. Sargent classify the early 1970s as a period that represented "a transformation in American foreign relations." 7 Indeed, this is how English Canadian left nationalists viewed the situation, regarding it as a transformation brought on by crises of capitalism. In the Marxist tradition, crises of capitalism are fundamental in creating the conditions favourable for a socialist transformation. Therefore, English Canadian left nationalists seized on the issue of American decline as the best, and perhaps last, opportunity to garner support for their agenda of independence through socialism.

The economic crisis of the early 1970s exposed the problem of Canadian political economy as articulated by Canadian neo-Marxist scholars and represented the height of the English Canadian left nationalist movement's political influence. Left nationalists aimed at independence from the American empire and the ending of Canada's perilous status as a semi-periphery economy. They believed their antiimperialism, premised on a Marxist interpretation of international relations and a declinist view of the United States, provided the means to free Canada from the perils of American imperialism and decline. This anti-imperialism formed the basis of English Canadian left nationalist politics.

${ }^{7}$ See Daniel J. Sargent, A Superpower Transformed: The Remaking of American Foreign Relations in the 1970s (New York: Oxford University Press, 2015). 
Anti-Imperialism in Close the 49th Parallel etc.

In expressing declinist sentiment, left nationalists were not merely reacting to events, as critics of declinism contended. ${ }^{8}$ An overarching theme was the "Americanization of Canada," which meant that American problems had become Canadian ones. These concerns were best represented by the contributions of left nationalists to Ian Lumsden's Close the 49th Parallel etc.: The Americanization of Canada, published in 1970. Prominent left nationalists, including Philip Resnick, Cy Gonick, Mel Watkins, Gerald Caplan, and James Laxer made contributions. Their writings offered an indication of the left nationalist worldview on the eve of the Nixon Shock.

Some left nationalists also believed that the decline of American global power presented Canada with an opportunity to take up neutralism. In Close the $49^{\text {th }}$ Parallel, the academic and Waffle activist Philip Resnick presented the case for a Canadian form of neutralism based on socialism. Resnick argued that it was in the interests of Canada's "liberal elites" to maintain a capitalist political economy closely linked to the United States, which rendered any plan for an independent foreign policy meaningless. Canada was a willing junior partner in the American empire because of its adherence to an "elite liberal capitalist ideology." Neutralism in defence and foreign policy could be achieved through socialism. "The alternative to the empire, today as in 1945, is not sentimentalism, but socialism." Resnick declared that "[o]nly a socialist economy can avoid extreme dependence on the American

${ }^{8}$ See Huntington, “The U.S.: Decline or Renewal?" 
market, both for free trade and for capital." 9 In the left nationalist framework of Canadian independence, socialism and neutralism were inextricably linked.

Reflecting on the recent history of Canadian-American relations, Resnick made a bold declaration that "revolutionary socialism" would have made Canada an independent world power. Resnick made one of the most direct calls for a program of socialism and neutralism:

[r] evolutionary socialism alone would have provided the rationale for neutralism in the Cold War. Rejecting capitalism and Stalinism, a socialist Canada might have been able to play a vital role in easing border tension between the two blocs [through] unilateral disarmament of the north ... and be much more forward in support of the liberation of the Third World from all imperialism...10

Neutralism would stave off Americanization. Resnick claimed that the "real threat" to Canada since 1945 came from the Americans, rather than the Soviets. Canada's "liberal capitalist elites" had betrayed their country through their pursuit of continentalism, which "let American imperialism into the gates." ${ }^{11}$ NORAD and the Liberal government's support for it represented the extent of Canada's willingness to be a junior partner of the American Empire. Resnick went as far as to equate Canada's membership in NORAD with the Warsaw Pact: “[Canada's] colonial mentality is self-imposed. The Canadian political elite is prepared to give freely what in Czechoslovakia ha[d] to be imposed - fealty to imperialist power."12 This rhetoric was not shocking to those who subscribed to left nationalism. Resnick and many of

\footnotetext{
${ }^{9}$ Philip Resnick, "Canadian Defence Policy and the American Empire," in Close the 49th Parallel Etc.: The Americanization of Canada, ed. Ian Lumsden (Toronto: University of Toronto Press, 1970), 112. 10 Ibid., 113.

${ }^{11}$ Resnick, "Canadian Defence Policy and the American Empire," 113.

${ }^{12}$ Czechoslovakia was invaded by Soviet forces in 1968 to suppress the Prague Spring. Ibid., 111.
} 
his companions in the English Canadian left nationalist movement were not Cold Warriors; they were disillusioned with, or outright hostile towards, the American policy of containment. The main aim in pursuing neutralism was to secure Canada's economic independence. Canada must first establish its independence in North America if it was to be entirely free to advance its interests on the world stage. Waffle activist, academic, and self-described Marxist Daniel Drache also advanced bold left nationalist rhetoric in his introduction to Close the 49th Parallel. He described Canada as "having come full circle from a colony to a colonial dependency."13 Drache situated Canada as part of the colonial world and argued that the time was ripe for a struggle for decolonization: "[a]n anti-imperial struggle is the only way to break through the tight circle of Canadian history. Anti-imperialism, anti-capitalism, and Canadian independence are an inseparable unity." In times of crisis, left nationalists should view themselves as part of a vanguard movement. Drache even suggested Communist-style revolutionary activities, proposing "people's committees" that would "investigate, document, then fight American imperialism in Canada." With this action, Canada could finally solve its central political issues resulting from "the historic role of the bourgeoisie in selling out Canada and the Americanization of all aspects of Canadian life."14 Drache's program of anti-capitalism and revolutionary socialism was clearly not realistic nor reflective of the left nationalist movement's wider political program. It reflected, however, the

\footnotetext{
${ }^{13}$ Daniel Drache, "The Canadian Bourgeoisie and its National Consciousness," in Close the 49th Parallel Etc.: The Americanization of Canada, ed. Ian Lumsden (Toronto: University of Toronto Press, 1970), 5-6.

${ }^{14}$ Drache, "The Canadian Bourgeoisie and its National Consciousness," 22.
} 
extent to which some left nationalists were willing to go in setting out both their views and contempt for Canada's imitation of American capitalism. Like many of his counterparts, Drache wanted Canada to take a completely different course and start again. Drache's ideal Canada would be fully socialist and independent from the American-led world economic system and all its problems.

Cy Gonick's contribution to Close the 49th Parallel offered one of the strongest examples of left nationalism and anti-imperialism. He claimed that Canada's situation was made worse by American attempts to maintain its dominant position in the world economy. In Gonick's view, Canada was reduced to a "small regional economy within the metropolitan economy of the United States." Canada was a "very valuable part of the American empire." Gonick insisted that, to understand the Canadian-American relationship, the relations between colony and metropole had to be studied. ${ }^{15}$ He divided the past decade of the politics of Canadian-American relations in the "corporate and political elite" into two schools of thought: "passivist" and "activist." In this analysis, there were no nationalists, only those who embraced continentalism, or aimed to strengthen Canada's position in the regional economy of North America. New Nationalists need not apply. Gonick had no patience for their proposals to review foreign direct investment or create Canadian-based multinational corporations. These moderate schemes, as Gonick described them, would not solve the problem of Canada as part of the American empire.

${ }^{15}$ C. W. Gonick, "Foreign Ownership and Political Decay," in Close the 49th Parallel Etc.: The Americanization of Canada, ed. Ian Lumsden (Toronto: University of Toronto Press, 1970), 44-5. 
Gonick claimed that the New Nationalists "think government should play a role in helping Canada gain a greater share of the continental pie," a measure which in his view was beside the point. ${ }^{16} \mathrm{He}$ cited Kari Levitt's assertion that "a balkanization of [Canada's] political structure [is occurring], whereby the growing economic powers of the corporations and the provincial governments threaten to destroy the Canadian state." ${ }^{17}$ Continentalization threatened Canada. The very existence of Canada was a risk because of the overbearing dominance of the United States, which meant that Ottawa's policies guiding the direction of Canada's cultural and economic future, "emanate more and more from Washington and the boardrooms of multinational corporations." ${ }^{18}$ Replacing capitalism was the only means of freeing Canada from the control of the American corporations.

James Laxer and Waffle co-founder Gerry Caplan also were clear in their characterization of the left nationalist movement as anti-imperialist. They stressed the need to draw on the experiences of other movements but insisted that a successful ani-imperialist strategy must be rooted in Canada's "unique geopolitical position," 19 a reference to Canada's position next to the American superpower. The United States was a direct threat to Canada and a major hindrance to the success of the Canadian socialist movement. "Our location next to the heart of the American empire imperils not only the socialist cause in Canada, but also the very survival of the nation itself." For Caplan and Laxer, the success of left nationalism depended on

\footnotetext{
16 Gonick, "Foreign Ownership and Political Decay," 45.

${ }^{17}$ Kari Levitt, quoted in Gonick, "Foreign Ownership and Political Decay," 69.

${ }^{18}$ Ibid., 69-70.

${ }^{19}$ Gerald L. Caplan and James Laxer, "Perspectives on Un-American Traditions in Canada," in Close the $49^{\text {th }}$ Parallel Etc.: The Americanization of Canada, ed. Ian Lumsden (Toronto: University of Toronto Press, 1970), 310.
} 
the transformation of the Canadian socialist movement into a force of antiimperialism. ${ }^{20}$

Gonick, Resnick, Caplan, and Laxer premised their left nationalism on their strongly held anti-imperialist views. For them, Canadian independence meant freedom from the American empire. The anti-imperialism advanced by these left nationalists made them receptive to declinism both before and after the Nixon Shock. Whether Canada's colonial relationship took the form of special status or a subjugated hinterland was beside the point. It was imperative that socialists tied their ambitions to resisting American imperialism. This view was made all the more important once it became apparent that the United States was suffering from imperial overstretch and economic decline. A left nationalist agenda was needed to prevent American problems from becoming Canadian ones. This contention marked the major differentiation between other nationalists, even those who subscribed to views on the left of the political spectrum.

The Nixon Shock and American Dependency and Decline

Nationalists who feared American domination of the Canadian economy were given cause for alarm by American President Richard Nixon's announcement of a "New Economic Policy" (NEP), commonly known as the Nixon Shock, because of its sudden damage to the international economy, in August $1971 .{ }^{21}$ The Nixon administration believed that the United States was declining rapidly compared to

\footnotetext{
20 Caplan and Laxer, “Un-American Traditions," 315.

${ }^{21}$ J. L. Granatstein and Robert Bothwell, Pirouette: Pierre Trudeau and Canadian Foreign Policy (Toronto: University of Toronto Press, 1990), 70.
} 
other major economies. To arrest this decline, the United States was taken off the Gold Standard, ending the Bretton Woods system. Worryingly for Canada, the United States imposed a surcharge of ten per cent on imports, a ten per cent tax credit for American-made machinery and equipment, and created the Domestic International Sales Corporation that allowed American companies to defer paying taxes on at least half of their profits earned from exports. Nixon did not care about how his new economic program would affect Canada. ${ }^{22}$

The Nixon administration made it clear that the United States would no longer readily pursue continentalism in the manufacturing sector. Alarmingly for the future prospects of Canada-United States trade relations, officials in the Commerce and Treasury Department proposed to scrap the Auto Pact. Enacted in 1965, the Auto Pact was a managed trade agreement that allowed manufacturers, if they met certain conditions, to ship cars and parts across the border duty-free. Economic nationalists in Washington were critical of the Auto Pact because they believed it safeguarded Canada's economic interests at the expense of the United States and was a major cause of the trade deficit. ${ }^{23}$ Luckily for Canada, at the last minute the proposed scrapping of the Auto Pact was removed from Nixon's speech announcing the NEP because the State Department was concerned that it would disrupt the North American automotive industry and damage Canadian-American relations. ${ }^{24}$ Despite this policy reversal, Canada was now regarded as part of the

\footnotetext{
${ }^{22}$ Bruce Muirhead, "From Special Relationship to Third Option: Canada, the U.S., and the Nixon Shock," American Review of Canadian Studies 34, no. 3 (2004), 439.

23 Muirhead, "From Special Relationship to Third Option," 433-34.

${ }^{24}$ Dimitry Anastakis, Auto Pact: Creating a Borderless North American Auto Industry, 1960-1971 (Toronto: University of Toronto Press, 2005), 165.
} 
cause of American economic problems and could no longer expect preferential treatment in the future.

Canada was shocked by the American turn to protectionism. Nixon's economic nationalism exposed Canada's precarious economic relationship with the United States. While Prime Minister Trudeau eventually got an exemption from the import tax, Canadians could be forgiven for not being reassured by Nixon's backtracking on applying his harshest measures on Canada. ${ }^{25}$ United States Treasury Secretary John Connally's widely reported justification of his new economic policies was means of "screwing foreigners" did not help calm nerves north of the border. ${ }^{26}$ Canada, dependent on American trade, faced hardship, or worse. Since the Second World War, Canada's economy enjoyed a "special status," described by historian Dimitry Anastakis as “the United States' willingness to embrace Canadian 'exceptionalism,"' giving Canada preferential treatment in economic and trade policy. ${ }^{27}$ This abruptly ended after Nixon's announcement of the NEP. As historian Bruce Muirhead explained, "Canadians [now] found themselves no different in American eyes than the Western Europeans and Japanese."28 Canadians could no longer rely on American goodwill to curb the worst excesses of dependency. For left nationalists and New Nationalists, Canada's vulnerabilities were put on full display.

\footnotetext{
25 For an account of how the Trudeau government dealt with the Nixon Shock and negotiated exemptions for Canada from the NEP, see Granatstein and Bothwell, Pirouette, 61-75.

26 John S. Odell, U.S. International Monetary Policy: Markets, Power, and Ideas as Sources of Change (Princeton, New Jersey: Princeton University Press, 1982), 263.

27 Anastakis, Auto Pact, 164-65.

${ }^{28}$ Muirhead, "From Special Relationship to Third Option," 439.
} 
For left nationalists the Nixon Shock exposed the true extent of Canada's position as a semi-periphery economy dependent on the United States. The Nixon Shock was nothing less than a crisis in Canadian-American relations and global capitalism. As Gonick argued, it was a symptom of the rapid decline of the American empire and was a desperate attempt at "re-ordering the world to her advantage." 29 In a brief titled, "The Canadian Crisis," submitted to the Ontario NDP executive by the Waffle group in the spring of 1972 (immediately prior to their expulsion from the party), left nationalist concerns were clearly delineated. Mirroring Gonick's assertions in his article "The American Empire: The Long Descent," the Ontario Waffle declared that "a key reality for Canadians is their hinterland status within the American empire, made more evident by the Nixon Shock." For the Ontario Waffle, Nixon's New Economic Program made clear the "inherent tendency of a capitalist system dominated by multinationals to under-develop hinterland countries." The Ontario Waffle feared that Canada was dragged into crisis by a United States gripped by a "crisis of empire." 30

Canadian left nationalists were preoccupied by the consequences of American imperialism. According to the left nationalist worldview, imperialism was an extension of capitalism, the product of major capitalist powers' need to seek foreign areas of investment, raw materials, and markets for manufactured goods. One often tried method of studying the power dynamics of relations between states

\footnotetext{
${ }^{29}$ Cy Gonick, "The American Empire: The Long Descent," Canadian Dimension, November-December 1973, 19.

30 "The Canadian Crisis," a brief submitted to the Ontario NDP by the Waffle, April 1972, CCF/NDP Fonds MG 28 IV-I, vol. 446, file 23.
} 
was an examination of the forces and relations of production found in the subjugated or periphery state. The political scientist J. Paul Grayson offers a concise overview of the Marxist view of the consequences of imperialism. In the Marxist worldview, "it is possible that an imperialist power may disrupt the existing forces of production through, for example, the introduction of new productive techniques." This led to consequences for the colony, or periphery, as "the imperialist power may leave the forces of production largely undisturbed but may, primarily though force, attempt to change the productive relations extant in society." ${ }^{31}$ The overarching theme of the imperialist exploitation of countries was that its primary purpose was the extraction of economic surplus from the subordinated country.

Marxists contended that Canada, because of its subordination to other economies, was a hinterland society where its economic surpluses flowed to the metropole. The metropole-hinterland, or empire-colony relationship was characterized by a power imbalance with the metropolitan imperial power holding the advantage. ${ }^{32}$ As Canadian left nationalists regularly claimed, many of the economic changes that occurred within Canada resulted from developments in the United States. As Kari Levitt, Mel Watkins, and James Laxer said, a readily identified consequence in Canada was structural unemployment resulting primarily from multinational corporations undertaking research and development operations in their home country. Canada was seemingly trapped in a metropole-hinterland relationship with the United States, a problem reinforced by American decline.

${ }^{31}$ Grayson, "Introduction," 8-9.

32 Ibid., 9. 
The left nationalist interpretation of American economic decline and foreign relations mirrored that of non-nationalist Marxists. The Trotskyist League for Socialist Action (LSA) also described the early 1970s as being characterized by a series of crises of world imperialism that were harbingers of the end of the global capitalist system. At the 1973 plenary session of the LSA, a resolution was adopted by the central committee that proposed a revolutionary response to the crisis. The resolution, "Canada and the Crisis of World Imperialism," described the aftermath of the Nixon Shock as marking a "growing period of instability and crisis in the world imperialist system." Where "the postwar expansion of capitalism had flagged, previous economic and political alignments have become unhinged; the painfully constructed world monetary structure is in shambles." 33 Socialists were presented with an opportunity to advance their cause, since "a simultaneous rise of class struggles and of inter-imperialist competition has challenged bourgeois stability in each country." ${ }^{44}$ This resolution, with its discussion of a "crisis," indicated that Canadian Trotskyists, like their international counterparts, were also declinists. Their worldview was premised on the notion that capitalism, represented by the United States, was in crisis and on the verge of collapse.

In the Trotskyist worldview, Canada was threatened by the crisis of imperialism, not because the national bourgeoisie was being assimilated by the Americans (a phenomenon referred to as Americanization), but because Canada was

\footnotetext{
${ }^{33}$ League for Socialist Action, "Canada and the Crisis of World Imperialism," in The Debate on Canadian Nationalism, 1968-1974. Socialist History Project. https://www.socialisthistory.ca/Docs/1961-/CanNat/CanadaCrisis73.htm.

34 Ibid.
} 
an imperialist power. This was a clear contrast with the left nationalist view. The resolution refuted the contention that Canada was being taken over by the United States. The authors claimed there was no evidence of it happening in any country.

Never to this day has a national bourgeoisie lost or given up control of its nation state except where defeated through war or revolution ... On the contrary, all the evidence points to the bourgeoisie's continuing reliance on the national state-capitalism is unable to jump out of its national skin, even to form continental unions, let alone fuse on a world scale.

Canada's "imperialistic character" was evidenced by "the participation of the ruling class in the imperialist exploitation of the colonial and semi-colonial world." 35 This assertion marked the major difference between the Trotskyists in the LSA and the wider English Canadian left nationalist movement. Both groups, however, agreed that Canada was in crisis because of American dependency and decline.

Having established that Canada was dependent on the United States, some left nationalists argued that Canada was a colony of the American Empire and would suffer the consequences of American decline. Where Gonick highlighted the parallels between American imperial overstretch and economic decline and the situation faced by the British Empire in the early twentieth century, the Waffle supporter and historian Michael S. Cross compared the Americans to the Romans. As Cross contended in 1970, Canada was a colony of the American Empire, like Gaul was to Rome:

We are the Gauls of the modern world, to your Rome, the northern foundation of your empire, conquered with sweet words, rather than swords and chariots ... It has been for us a beneficial empire, sharing with us its capital, its technology ... sending north its young proconsuls to civilize and

${ }^{35}$ League for Socialist Action, "Canada and the Crisis of World Imperialism." 
educate us. Always the imperial hand has been covered with the velvet glove. Indeed, we have been velvet-gloved to death. ${ }^{36}$

The Nixon Shock the following year removed the "velvet glove" from the hand of American empire. In Cross's view, Canada was not the "anti-America." It was the Roman province of Gaul happy to remain a colony as long as it reaped the benefits. The implication was that like the Gauls, Canadians would suffer because the American empire, like Rome before it, was in rapid decline. Canada's special status had ended. It was time for an agenda of independence through socialism. ${ }^{37}$ Mel Watkins was not as defeatist but agreed with Cross' assessment of Canada's colonial relationship with the United States. Expressing the common left nationalist refrain, Watkins believed that the Nixon Shock exposed the true extent of Canada's vulnerabilities resulting from American dependency. Watkins claimed that Canada's perilous situation was compounded by the weakness of the United States, the decline of its "world hegemony," and a crisis of capitalism. The Nixon Shock marked a turning point for Canada's relationship with the United States, for Watkins believed that Canada's "special status within the American empire" had ended. Canada now faced uncertainty, or even a reckoning. In the past, economic prosperity and security might have been tolerated as a good trade-off for the loss of sovereignty, but Watkins believed that Canada's future prospects were grim as American economic hegemony eroded, replaced by a "new era of inter-imperialist rivalry among capitalist blocs." 38 Watkins' views on the decline of the United States

\footnotetext{
36 Michael S. Cross, “Canada and the American Empire," Canadian Forum, April-May 1970, 72-73. 37 Ibid., 73.

38 Watkins, “Contradictions and Alternatives in Canada's Future," 254-5.
} 
and the emergence of a new world order were widely shared by academics and policy makers; Washington was also consumed with debates over how to arrest American decline. ${ }^{39}$

James Laxer agreed with Watkins' negative interpretation of the significance of the Nixon Shock. He drew attention to the likelihood of further American exploitation of Canada's resources. Nixon's quest to end the "unfair" trading practices of other nations had dire consequences for Canada and Watkins suspected that United States access to Canada's energy resources would be made permanent, and in return, the United States would sell more manufactured goods to Canada. According to Laxer, this new trading relationship would decimate Canada's already weak manufacturing sector. ${ }^{40}$ In characteristic Marxist language, Laxer argued that the deindustrialization of Canada was the product of the nature of "Canadian capitalism and its relationship to American capitalism." Echoing left nationalists during this period, Laxer contended that Canada would suffer disproportionately from American decline due to its dependent status. "Only an anti-imperialist struggle bringing workers together can reverse the present stagnation in Canadian industry and its attendant costs for the Canadian people." ${ }^{41}$ Canada had to reject the capitalist status quo and embrace socialism and anti-imperialism to properly address its economic problems.

\footnotetext{
${ }^{39}$ Muirhead, "From Special Relationship to Nixon Shock," 440.

40 James Laxer, "Canadian Manufacturing and U.S. Trade Policy," in (Canada) Ltd.: The Political Economy of Dependency, ed. Robert Laxer (Toronto: McClelland and Stewart, 1973), 145-6.

${ }^{41}$ Laxer, "Canadian Manufacturing and U.S. Trade Policy," 146.
} 
The Wahn and Gray Reports

The federal government was also concerned with American dependency and decline and the ramifications for Canada's economic prospects. In August 1970, a year prior to the crisis resulting from the Nixon Shock, the House of Commons Committee on External Affairs and National Defence issued its Eleventh Report (Wahn Report), which recommended moderate government intervention to stave off the negative effects of American foreign investment and proposed that the government work towards securing fifty-one per cent ownership of the Canadian economy. The findings of the Wahn Report further strengthened the resolve of left nationalists. The report urged the government to counter the dominance of American-owned multinationals to avoid a situation where the government found itself "in a position of dependency with relation to the United States [where] it will be afraid ... to adopt policies displeasing to the United States because of the fear of American reprisals involving possible or unacceptable costs to Canada." 42 The report repeated Watkins' earlier recommendation for a federal agency tasked with increasing Canadian participation in the management of foreign firms, laws that countered American extraterritorial jurisdiction over subsidiaries, and the creation of a Canada Development Corporation. Wahn went further than the Watkins Report, recommending a screening process for future foreign takeovers of Canadian firms, which would need the consent of a review agency. Critical sectors of the economy (beyond telecommunications and banking) were identified where further foreign

42 Abraham Rotstein, "Development and Dependence," in Independence: The Canadian Challenge, ed. Abraham Rostein and Gary Lax (Toronto: McClelland and Stewart, 1972), 36. 
takeovers would be prohibited. ${ }^{43}$ The Wahn Report's findings revealed there was a growing realization that government intervention in the economy was needed to deal with the problem of Canadian political economy in the early 1970s: the dominance of the American multinational in the economy.

The Wahn Report did not recommend a program of nationalization and was dismissed by left nationalists as a series of "half measures" that would not address the fundamental problems of the Canadian-American relationship. Gonick, in his review of the Wahn Report, wrote that it offered further evidence of the shortcomings of "reforming capitalism." Socialism offered the clearest means of dealing with the problems of American dependency and shielding Canada from the American imperial system. Gonick claimed that the Report's recommendations reflected the views of the "Toronto Star - Walter Gordon - Abraham Rotstein axis" of the Committee for an Independent Canada. The report's recommendations were not in-line with left nationalism, because they "go about as far as it is possible to go within the bounds of liberal capitalism." ${ }^{4}$

For Gonick, reforming capitalism was not the answer, because in Marxist terms, capitalism was the problem. Gonick made a point of quoting Walter Gordon, who claimed that the Wahn Report's recommendations offered the last hope of staving off the "socialist alternative." Gonick summarized the views held by left nationalists that differentiated them from other players such as Gordon and Rotstein:

\footnotetext{
${ }^{43}$ House of Commons, Eleventh Report of the Standing Committee on Defence and External Affairs Respecting Canada-U. S. Relations (Ottawa: Queen's Printer, 1970).

${ }^{44}$ Cy Gonick, "Liberal-izing Continentalism," Canadian Dimension, October-November 1970, 4.
} 
Foreign ownership is an issue in Canada only because the key decisions affecting Canada are not made in this country but in the USA; because Canada has been made into a resource colony for American industry and a consumer market for American manufacturers. The $51 \%$ formula will not change any of this. Canada would still remain a resource colony for the US, exporting jobs and importing finished goods; key decisions would still be made in private US boardrooms; there would be no less distortion between public goods and private goods, no less poverty or inequality; the oppression of working men and women, students and farmers would not have diminished. Independence is a priority for socialists because without it we cannot control our economy and our resources and our basic institutions to remake our society. ${ }^{45}$

Still, Gonick was optimistic, concluding that the Wahn Report's recommendations would fail to stave off American dependency, and as a result, "the socialist answer will find its place on Canada's political agenda." The reaction to the Report demonstrated there were differences between left nationalists and the reformism of the New Nationalists.

Still dealing with the ramifications of the Nixon Shock of the previous August, Trudeau's chief foreign policy advisor, Ivan Head, presented the government's new outlook in a January 1972 article in Foreign Affairs titled, "The Foreign Policy of the New Canada." Speaking to an American audience, Head quoted Prime Minister Trudeau's widely repeated characterization of Canadian-American relations: “Living next to the United States is in some ways like sleeping with an elephant. No matter how friendly and even-tempered is the beast, one is affected by every twitch and grunt." ${ }^{46}$ Head acknowledged that there had been frequent fear about American economic policies because Canada was highly dependent on the United States for its

\footnotetext{
${ }^{45}$ Gonick, "Liberal-izing Continentalism," 5.

${ }^{46}$ Ivan Head, "The Foreign Policy of the New Canada," Foreign Affairs 50, no. 2 (January 1972), 238. For an account of Head's tenure as Trudeau's foreign policy advisor see, Ivan Head and Pierre Trudeau, The Canadian Way: Shaping Canada's Foreign Policy, 1968-1984 (Toronto: McClelland and Stewart, 1995).
} 
prosperity. According to historians J. L. Granatstein and Robert Bothwell, Head had recently read works by dependency theorist Paul Sweezy and a result he feared the rapid decline of the United States and its descent into imperialism. ${ }^{47} \mathrm{He}$ recognized that Canadians were alarmed that an estimated thirty per cent of American worldwide foreign investment was located in Canada. He believed that concerns about close ties to the United States should be heeded because American economic decline threatened Canada. "American inflation becomes our inflation; [the] diminishing of American capital outflows means a decrease in our growth rate; American protectionism means Canadian unemployment."48 Trade diversification and controls of foreign direct investment would address the problems of American dependence in the long term.

In the meantime, Head acknowledged the existence of "militant Canadian nationalists" and their insistence on a rapid end to dependency but claimed their agenda would "come at great cost to Canadians as individuals, and Canada's relations with the United States," adding that "neither country wants to see such a schism." Head expressed his frustration with the Nixon Shock of August 1971 since it damaged the Canadian economy and relations with the United States. ${ }^{49}$ While Nixon did not deliberately set out to hurt Canada (the import surcharge was aimed at Western Europe and Japan), Head believed that indifference on the part of the

\footnotetext{
${ }^{47}$ Granatstein and Bothwell, Pirouette, 68.

${ }^{48}$ Head, "The Foreign Policy of the New Canada," 238.

${ }^{49}$ Ibid., 245.
} 
Americans to Canadian concerns could be equally damaging to the CanadianAmerican relationship. ${ }^{50}$

In addition to Head's musings, the leaked 1972 Cabinet Report on Foreign Direct Investment in Canada, known as the Gray Report, expressed many of the concerns of New Nationalists and left nationalists, particularly regarding the balance between the resource and manufacturing sector. ${ }^{51}$ Written by a cabinet working group chaired by minister Herb Gray, the report expressed the concern that foreign direct investment led to an emphasis on quick extraction and a lack of investment in manufacturing and refining raw materials. The report found that "investment decisions of foreign-controlled corporations tend to reflect the laws and industrial priorities of foreign governments and economies, which in turn, influence Canadian industrial priorities." Anticipated future demand for resources could lead to "undue emphasis on resource development in the coming decades, [which] could impose major limitations on the ability of Canadians in future to formulate an industrial development policy geared to Canada's particular growth and employment objectives." Significantly, the Gray Report found that "the substantial degree of foreign investment in Canada has carried ... significant economic and social costs [such as] truncated enterprises, in which many important activities are performed abroad by parent or other affiliated firms." 52 These findings reflected the arguments

\footnotetext{
${ }^{50}$ Head, "The Foreign Policy of the New Canada," 251-2.

${ }^{51}$ A version of the report was published by Canadian Forum. The full title was Herb Gray, Foreign Direct Investment in Canada (Ottawa: Government of Canada, 1972).

52 Foreign Direct Investment in Canada, 6.
} 
of left nationalists and New Nationalists concerned with the dominance of the American multinational and branch plant in Canada.

Yet, left nationalists did not believe the recommendations of the Gray Report were sufficient in addressing the problem of American dependency. The report was not a radical document, since it made clear that government should foster the growth of Canadian private enterprise and not embark on a program of nationalization. The Gray Report described the extent of the problems facing the Canadian economy in the early 1970s. It found that the extent of foreign ownership and control of economic activity was significantly higher than in any other industrialized country. Approximately sixty per cent of manufacturing was foreign owned, with over ninety per cent control in the petroleum and rubber industries. Approximately eighty per cent of foreign investment came from the United States. The report did acknowledge that most foreign investment since the Second World War contributed to economic growth and prosperity. However, the report claimed that Canada had benefited immensely from ready access to American technology, capital, entrepreneurship, new managerial skills and access to new markets abroad. ${ }^{53}$ The Report also did not regard the multinational corporation as a fundamental threat to national sovereignty, even suggesting that the government encourage Canadian-based multinationals. ${ }^{54}$

Moderate economic nationalists, such as those in the federal cabinet, the Committee for an Independent Canada, and the NDP establishment, were mostly

${ }^{53}$ Foreign Direct Investment in Canada, 6.

${ }^{54}$ Ibid., 438. 
receptive to the Gray Report's conclusions and recommendations. Left nationalists, however, widely panned the report because it did not recommend nationalization schemes or the transformation of the Canadian economy along socialist lines. Gonick dismissed the Gray Report and the debate over its recommendations as just a "debate between two schools of continentalists," and claimed the difference between Gordon and Trudeau was that "Gordon [was] an activist and Trudeau an imperialist." 55 Moderation and reform would not address the problem of American dependence.

Not Starting Over: Alternatives to Left Nationalism

The Wahn and Gray Reports demonstrated that concern with American decline and Canada's status as a hinterland were not the sole domain of Canadian Marxists and left nationalists. Others involved in the Committee for an Independent Canada, such as Abraham Rotstein and Walter Gordon, were concerned with the high levels of foreign investment and the consequences for Canada's long-term prospects. A unifying theme with all English Canadian nationalists was a belief that the United States' declining economy plunged Canada into hard times and Canada needed to look to alternatives to relying on American investment. They shared a declinist view that the United States was overburdened both at home and abroad. As the diplomat and international affairs professor John W. Holmes observed in 1970, "basically there has been a loss of faith in Pax Americana." 56 Even the Globe and Mail,

55 Gonick, quoted in Watkins, “Contradictions”, 261.

${ }^{56}$ John W. Homes, The Better Part of Valour: Essays on Canadian Diplomacy (Toronto: McClelland and Stewart, 1970), 180. 
usually unsympathetic to the nationalist cause, acknowledged that "we have lately learned, and are still learning, that Canada's economic and political dependence on the United States is not as easy, secure or undemanding as Canadian complacency has tended to assume in the past." 57 Nationalists wondered if Canada would share a similar fate to that of the United States and they urged Ottawa to address the situation.

New Nationalists who were on the left of the political spectrum sought solutions of their own to Canada's dependence on the declining United States. Abraham Rotstein, was, as we have seen, a nationalist who held leftist views. Rotstein wanted to find a middle way between the anti-imperialism of the left nationalists and the capitalist reformist measures advanced by most New Nationalists. Rotstein did share the left nationalist concern with Americanization and the desire to reinvigorate socialism, but he viewed anti-imperialism as a reactionary response to problems that might prove to be temporary. It was not unreasonable to believe that the anti-imperialist agenda would disintegrate if the United States managed to arrest its decline and addressed the problems that the left nationalists railed about. Rotstein claimed the left nationalist criticism of the United States and its political agenda, along with concerns with American decline, were reflective of their American counterparts in the New Left and the anti-Vietnam War movement. He asked "is the raison d'etre of Canadian independence based on the permanent failure of the American left? If ... Americans were to change course and become a social democracy would the authors of the [Waffle] Manifesto logically be

57 “The Visit Could Have Value," Globe and Mail, October 16, 1971. 
required to become continentalist?" 58 This spoke to the tension between

nationalism and the internationalist tendencies of left-wing politics. Canadian left nationalists were trying to protect Canada from the domination of the United States, which they believed was reactionary, militaristic, and a threat to Canadian independence.

Rotstein did not share the left nationalist and populist desire to remake Canada into a democratic socialist state. ${ }^{59}$ He was skeptical about nationalization beyond the resource sector, arguing it was out of touch with recent trends in leftist thinking such as the functional socialist model adopted by Sweden. ${ }^{60}$ As an alternative to left nationalism and a solution to Canada's economic predicament, Rotstein proposed that Canada implement functional socialism as outlined by the Swedish sociologist Gunnar Alder-Karlsson. This theory outlined the Swedish "middle-way" between Soviet Communism and American laissez-faire capitalism. Functional socialism placed key sectors of the economy and specific functions of free enterprise under state regulation to maximize the "national interest." As AdlerKarlsson described it, Sweden nationalized the most important functions of ownership: "what Swedish socialism has done ... is to take away, or regulate, a

\footnotetext{
${ }^{58}$ Abraham Rotstein, Precarious Homestead: Essays on Economics, Technology, and Nationalism (Toronto: New Press, 1973), 73.

${ }^{59}$ While Rotstein was opposed to the left nationalist agenda, he remained receptive to some of its views. Rotstein and Watkins were friends and colleagues. On Rotstein's passing in 2018 Watkins wrote: "For more than 50 years, going back to the days of the old Department of Political Economy, Abe was my colleague in teaching and researching economic history and political economy, my intellectual soulmate, and my closest friend. I have many fond memories." Mel Watkins, "Abraham Rotstein and the Radical Decade from the Mid-Sixties to the Mid-Seventies," Progressive Economics Forum, October 19, 2018. http://www.progressive-economics.ca/2018/10/19/abraham-rotsteinand-the-radical-decade-from-the-mid-sixties-to-the-mid-seventies/

${ }^{60}$ Rotstein, Precarious Homestead, 69.
} 
number of those functions which the capitalists themselves regulated earlier, and still regulated in many other countries." 61 There was neither full nationalization as the left nationalists proposed, nor the minor scheme of screening the ownership of industry and foreign investment. Rotstein believed that functional socialism, in contrast to democratic socialism, had a proven track record and offered Canada a model that was sustainable and independent of trends south of the border.

Rotstein viewed Sweden as a model for Canada. As a middle power, the Swedes had pursued a neutral role in the Cold War, which he believed had proved successful in preserving independence while being in close proximity to NATO and Warsaw Pact forces. As Rotstein pointed out, there were other factors that made Sweden an exemplary nation in the eyes of many Canadians. Rotstein cited the "close competition in the race for the second-highest standard of living in the world. .. The common tradition of peaceful political change, and the rapid evolution of comprehensive social welfare policies." 62 Sweden could be an inspiration for Canada since its economy was mostly independent and was isolated from the illeffects of American decline. Rotstein was instrumental in having Alder-Karlsson's work published in Canada and he hoped to foster greater intellectual exchange between the two countries. However, his main motivation in introducing Canadians to functional socialism was to offer an alternative to left nationalism. He believed that Adler-Karlsson had "unwittingly given us a theoretical key to an overwhelming

${ }^{61}$ Gunnar Adler-Karlsson, Reclaiming the Canadian Economy: A Swedish Approach Through Functional Socialism (Toronto: House of Anansi Press 1970), 116.

${ }^{62}$ Abraham Rotstein, "Introduction," in Gunnar Adler-Karlsson, Reclaiming the Canadian Economy (Toronto: House of Anansi Press 1970), ix. 
problem faced in this country, almost unknown in Sweden - the foreign domination of the economy." 63

Rotstein portrayed functional socialism as a middle-way economic nationalist agenda. It offered a practical alternative to the calls for full nationalization by the left nationalists, or the "buy-back" of the Canadian economy proposed by moderates such as Walter Gordon. ${ }^{64}$ Rotstein believed that the nationalist debate was at an impasse, with both sides proposing polarized schemes that were unlikely ever to be realized. Nationalists had to be reasonable in their aims.

For it is not a question of principle whether any of the functions of ownership should be under public control. When that is realized, the slogans fall away, and the serious, difficult business of deciding what kind of country we want can begin, the national debate can re-enter the world in which the participants live. It is even possible that national action can begin. Let us set aside the debate, then, about nationalization versus free enterprise. ${ }^{65}$

Rotstein was hopeful that this approach would win adherents in all political parties. He believed buying back foreign-owned corporations was too expensive and nationalization too reckless. He stressed the urgency of the task at hand: "the struggle for independence must come first because we will lose it forever if we wait until a majority of Canadians are prepared to nationalize IBM and Inco." Rotstein saw the full-nationalization schemes proposed by the left nationalists as harmful to the Canadian economy, pointing to Eastern Europe as evidence of its failure to bring prosperity. ${ }^{66}$ Rotstein's hope that the Swedish example would unify all sides of the

\footnotetext{
${ }^{63}$ Rotstein, "Introduction," xii-xiii.

${ }^{64}$ Ibid., xiii.

65 Ibid., xiv.

${ }^{66}$ Ibid., xv.
} 
economic nationalist movement was overly optimistic. Left nationalists dismissed Rotstein's views as the old-fashioned social democracy that failed in the critical matter of preserving Canada's independence.

Left nationalists such as Watkins did not share Rotstein's optimism that functional socialism was the answer to Canada's economic problems. Watkins also dismissed the CIC's assertion that it was more practical for Canada to become a viable independent capitalist country, arguing "it has little to support it by the way of either analysis or historical evidence." Watkins claimed that the CIC's true agenda was to implement Rotstein's Swedish functional socialist agenda, which he thought was nothing but "new-fangled words that [meant] something old fashioned, called government regulation of private enterprise." It was ludicrous to heavily regulate the two-thirds of corporations operating in Canada that were foreign-owned, especially in the face of likely American opposition: "at best there could be some marginal increase in net benefits if the Nixon administration obliges." 67

Watkins had little patience for social democracy, which he believed was incompatible with anti-imperialism and even nationalism. In his view a social democratic agenda such as the one proposed by Adler-Karlsson merely sought to temper and guide the capitalist state. Watkins thought it was foolish to assume that the same corporations that would resist nationalization would instead readily accept heavy regulation. ${ }^{68}$ Watkins equated functional socialist schemes to the approach of the federal NDP, to which he was opposed. "It turns out to be no

\footnotetext{
${ }^{67}$ Mel Watkins, "Contradictions and Alternatives in Canada's Future," in (Canada) Ltd.: The Political Economy of Dependency, ed. Robert Laxer (Toronto: McClelland and Stewart, 1973), 258-9. ${ }^{68}$ Ibid, 259.
} 
accident, then, that the CIC and the NDP have the same position on foreign ownership ... such a strategy to the extent that it would be effective at all is not about independence but is rather about tidying up after the multinationals, of trying to get more benefits and fewer costs from dependence." On this point Watkins agreed with Gonick, believing that neither the CIC nor the NDP were serious about independence. Watkins claimed that "it is all a debate between the two schools of continentalism." ${ }^{69}$ His outright rejection of Rotstein's proposal for implementing the Swedish approach demonstrated that the two nationalist camps were far from reconciling their differences when it came to addressing Canada's dependence on the United States.

Canadian independence was not exclusively a concern of the political left and centre. In 1973 the intellectual George Woodcock in Canadian Forum wrote his influential piece "A Plea for the Anti-Nation," where he put forward an alternative plan for Canadian nationalists based on decentralization, arguing that this was the elusive alternative to left nationalism. Woodcock also wanted Canada to start over and become an "anti-nation." He believed that the nationalist question consumed Canada. Instead, he envisioned Canada being at the forefront of the "post-nationalist age" and "world communities of sovereignty." Woodcock feared that Canada's desire for independence from the United States would lead it to the destructive nationalism of the early 20 th century. ${ }^{70}$

\footnotetext{
${ }^{69}$ Watkins, "Contradictions and Alternatives in Canada's Future," 259.

70 George Woodcock, "A Plea for the Anti-Nation," in Nationalism or Local Control: Responses to George Woodcock, ed. Viv Nelles and Abraham Rotstein (Toronto: New Press, 1973), 5-6.
} 
Woodcock also feared that the nationalism expressed by Canadian leftists would create a country that was highly centralized, engaged in socialist planning, and stifled local identity. As a self-described anarchist, Woodcock was wary of a merger of nationalism and socialism. He argued that socialists only measured national prosperity and progress through material gain, and economic expansion would inevitably lead to the depletion of the world's resources and destructive competition among states. ${ }^{71}$ Woodcock, however, recognized Canada's dependence on the United States, made more evident by the events surrounding the Nixon Shock. He turned his attention to the other Canadian nationalists who were not leftists. These Canadian "patriots," Woodcock argued, must take up the "great task of the 1970s" of freeing Canada from a "complex and insidious American colonialism... . even if this means a reduction in the standard of living for many people."72 This "great task" would not be accomplished through socialist planning or nationalization. Instead, Woodcock's alternative was "local control," where Canada was strengthened through regional and local decentralization. Woodcock missed the point of left nationalism, since turning Canada into a utopian "anti-nation" would represent a surrender to its fate as a meaningless entity in a world dominated by the United States and the Soviet Union.

In a contrasting view, Desmond Morton, was dismissive of left nationalism altogether, arguing that it was an Ontario-centred concern, which, despite the Nixon

\footnotetext{
${ }^{71}$ Woodcock, "A Plea for the Anti-Nation," 10-11.

72 Ibid., 5-6.
} 
Shock, "served only to sell books and advance political and academic careers."73 Morton described Woodcock as a "libertarian decentralist," whose policies were a welcome alternative to the socialists, but would actually serve to hurt the cause of Canadian independence. While Woodcock's vision of a decentralized Canada containing smaller and more powerful provinces might make the country adaptable to a post-national future, it would not solve the issue of the power of the American corporation in Canada. Morton believed that the provinces would not be able to collectively resist the influence of the American multinational; only a stable central government could exert power needed to counter their influence.

The federal government had its own solution. Canadian-American Relations: Options for the Future, released during the 1972 election, proposed that Canada reduce its dependence on the United States. The "Third Option" was presented by External Affairs Minister Mitchell Sharp as an alternative to the status quo of American dependence or greater integration with the United States. It called for Canada to place its attention on growing trading relationships in Western Europe in Asia, as a counterbalance to reliance on the American market. ${ }^{74}$ Sharp's plan was optimistic about Canada's trading opportunities. Western Europe and Japan, while undergoing rapid economic expansion, were also strongly protectionist. ${ }^{75}$ Canada

\footnotetext{
${ }^{73}$ Desmond Morton, "Independence: It Won't be Easy," in Nationalism or Local Control: Responses to George Woodcock, ed. Viv Nelles and Abraham Rotstein (Toronto: New Press, 1973), 17-18.

${ }^{74}$ Canadian policy-makers were optimistic about the prospects of trade with Western Europe as a counterbalance to the United States. Historian Bruce Muirhead speculated that officials in the Trudeau government remained influenced by Claude Julien's book Canada: Europe's Last Chance, published in 1965. It called for Canada to increase its ties with Europe as an alternative to being "colonized by the United States." Claude Julien, Canada: Europe's Last Chance, (Toronto: Macmillan, 1965), 6; Muirhead, "From Special Relationship to Third Option," 456.

${ }^{75}$ Muirhead, "From Special Relationship to Third Option," 456.
} 
was dependent on the United States because it was an economic superpower. The reality was that no other market existed that could counter the United States in a significant way when it came to international trade.

The October 1972 election reduced the Trudeau Liberals to a minority position in the House of Commons, where they won just two more seats than the opposition Progressive Conservatives and had to rely on support from the New Democratic Party to pass legislation. ${ }^{76}$ With NDP pressure, the Foreign Investment Review Agency (FIRA) was established in 1973, charged with determining if foreign acquisitions of Canadian corporations served the national interest. ${ }^{77}$ This was not a victory for left nationalism. The historians John Herd Thompson and Stephen J. Randall describe these measures as representative of nationalism's "capitalist dimension," where some tinkering with the levels of foreign direct investment would restore a favourable position to Canadian businesses. ${ }^{78}$

Left nationalists such as Mel Watkins were not pleased with what he called the "Trudeau half measures." Only a fundamental reworking of the Canadian political economy, he thought, would remove it from its dependent position. Watkins referred to FIRA as being comparable to having a "referee at a rape."79 The

\footnotetext{
76 The Liberals won one hundred-nine seats, the Progressive Conservatives one hundred-seven, the NDP thirty-one, and Social Credit fifteen.

${ }^{77}$ In its first year, the Foreign Investment Review Agency considered eighty-two cases of foreign takeovers of Canadian corporations. Fifty-five were approved, eleven rejected, and sixteen were withdrawn. For a contemporary and positive review of FIRA's performance and its role in mitigating foreign takeovers see Herb Gray, "Good Fences: Controlling Foreign Investment," Canadian Forum 55 (June 1975).

78 John Herd Thompson, and Stephen J. Randall, Canada and the United States: Ambivalent Allies (Montreal: McGill-Queen's University Press, 1994), 257.

79 Ryan Edwardson, “Kicking Uncle Sam out of the 'Peaceable Kingdom': English Canadian 'New Nationalism' and Americanization," Journal of Canadian Studies 37, no. 4 (Winter 2002-2003), 143.
} 
strategy for dealing with foreign investment recommended by the Gray Report would amount to "tidying up after the multinationals," and "getting more benefits and fewer costs from dependence." ${ }^{80}$ Even the New Nationalist Walter Gordon expressed his disappointment, calling FIRA “a joke." ${ }^{81}$ It was also during this period that the Waffle stepped up its agitation against the NDP leadership after James Laxer's loss to David Lewis in the 1971 leadership convention, and several books with Marxist overtones that denounced the imperialism of the United States were published. Left nationalists continued to agitate for a socialist Canada as the only effective means of countering American economic dependency.

Confronting Dependency and Decline in Robert Laxer's (Canada) Ltd.

In 1973, Robert Laxer, in his introduction to Canada (Ltd): The Political Economy of Dependency, described the lacklustre Liberal efforts at nationalism and at addressing the Nixon Shock as an inadequate "moderate liberal-reformist" approach to American dependency. Laxer argued that the liberal-reformers tolerated American domination of the Canadian economy and sought to temper the negative implications of excessive American direct investment by "prescribing good corporate citizenship, government regulation, and screening of foreign companies, and pluralist checks and balances in a well-ordered liberal-reformist or welfare society." In contrast, he described the opposing left nationalist camp as "those who confront the American empire with a basic socialist critique and a far-reaching

80 Watkins, “Contradictions and Alternatives in Canada's Future," 261.

${ }^{81}$ Edwardson, "Kicking Uncle Sam out of the 'Peaceable Kingdom,"' 143. 
strategy of public ownership." 82 Laxer blamed the liberal-reformist approach for the "hinterland mentality" that often beset Canadian business and political leaders. He characterized this mentality as defeatist, since it was based on "bartering resources for the finished goods of the advanced metropolis, with the hope the assembly-line manufacturing and supply depots will remain profitable to the [American] companies and leave some jobs for Canada." ${ }^{83}$ The liberal-reformist approach to securing Canadian independence would fail because it was premised on a continentalist mentality.

The left nationalist, "anti-imperial," and statist analysis of Canada's dependence problem interpreted continentalism, in Laxer's words, as a "crushing blow to the Canadian people and [provided] the promising potential of an alternative society free from the exploitation and decay of the empire of Standard Oil." Unlike the "liberal-reformist" approach, reducing unemployment would be a major priority of the socialists; their approach would "projec[t] a society of open opportunities through an expanding economy in which resources create employment in Canadian manufacturing instead of serving as unprocessed raw materials for export abroad." 84 A socialist Canada, where all industry was stateowned, would result in greater employment in the manufacturing sector, which had suffered from chronic underinvestment by the parent companies as described in the Gray, Wahn, and Watkins Reports.

\footnotetext{
82 Robert Laxer, "Introduction," in (Canada) Ltd.: The Political Economy of Dependency, ed. Robert Laxer (Toronto: McClelland and Stewart, 1973), 9.

83 Ibid., 9-10.

${ }^{84}$ Ibid., 10
} 
In Robert Laxer's view, the left nationalist movement proved there was an impulse for radical action within some segments of the Canadian population, since it "challenged the myth that Canadians are so fixedly anti-socialist that they would abandon their country's sovereignty rather than choose public ownership and control of resource industries, large-scale manufacturing, and financial institutions." 85 The Gray Report and the tempered economic nationalism of the Trudeau Liberals were insufficient since "Canada is in the grip of the economics and politics of dependency." Laxer believed the Canadian business community, and the Liberal and Progressive Conservative parties, were resistant to meaningful measures to limit American branch plants and direct investment because they were beholden to their "American masters." 86 With the claim that American direct investment caused deindustrialization, left nationalists refuted the belief held by their opponents that significantly reducing and reversing investment would threaten Canada's prosperity.

James Laxer's contribution to (Canada) Ltd aimed at defining the history and trajectory of Canada's political economy and answering the question that Marxist scholars grappled with during the 1970s: how could Canada be so rich but at the same time be dependent on the United States? ${ }^{87}$ He posited that Canada was not destined for dependency on either Britain or the United States; it was a "function not of geography and technology, but of the nature of the capitalist class." The

\footnotetext{
${ }^{85}$ Robert Laxer, "Introduction," 10.

86 Ibid., 11.

${ }^{87}$ James Laxer, "Introduction to the Political Economy of Canada," in (Canada) Ltd.: The Political Economy of Dependency, 27.
} 
historical weakness of Canadian capitalism allowed dependency to shape the characteristics of a capitalist class "that has needed continued dependency for its continued well-being." ${ }^{8}$ The Laxers believed that the political parties, the business elite, and the entire structure of the Canadian economy were dependent on the United States. This analysis served to bolster the claim that only a fundamental reworking of the Canadian economy along socialist lines, not the moderate reforms proposed by the Gray Report and enacted by the Trudeau government, would end Canada's dependence on the United States.

James Laxer worried that American economic decline had direct consequences for Canada's prosperity. He focussed his attention on American trade practices and deindustrialization in Ontario and used his findings as the basis for a rallying cry for workers to embrace socialism as a tool of anti-imperialism. He claimed that deindustrialization was the result of Canadian capitalism's relationship with American capitalism. Returning to his refrain on American imperialism and the social-ills of Canada's southern neighbour, Laxer argued that deindustrialization was "the price workers pa[id] for Canada's dependent status in the American empire. As ... [it] enters a period of decline, the costs ... are passed in disproportionately high amounts to workers in dependent countries like Canada and to minorities like blacks in the United States." Using Marxist language, Laxer argued, "[o]nly after an anti-imperialist struggle bringing workers together can

88 James Laxer, “Introduction to the Political Economy of Canada," 29. 
reverse the present stagnation in Canadian industry, with its attendant costs for the Canadian people." 89

As part of his new economic strategy Nixon had criticized Canada for not importing more American manufactured goods in exchange for increased American imports of Canadian resources. Nixonomics, and the crisis resulting from the Nixon Shock, compounded the economic pressures placed on Canada and strengthened the advantages of American-owned manufacturing and resource extraction firms. Laxer argued that resource extraction provided lower levels of employment than the manufacturing sector, leading to "permanent high unemployment." 90 The decrease in employment in the manufacturing sector could not be associated primarily with automation and decreases in demand.

Laxer claimed that American investment was the cause of many of Ontario's economic problems, such as high unemployment and deindustrialization. He found that, from 1966 to 1972 , there was significant growth in employment (nearly three times higher) in Canadian-owned factories compared to American ones. The divergence increased during the period from 1971 to 1972, when American firms used the wealth created by their increased activity in Canada to create jobs at their factories in the United States. American firms had maintained their market share and output by importing more American made parts in the manufacturing process in Canada. Laxer held that his study categorically refuted the claim that Canada benefited from American direct investment,

${ }^{89}$ James Laxer, “Canadian Manufacturing and U.S. Trade Policy," 146.

${ }^{90} \mathrm{Ibid}$. 
... during the present period of inter-imperial rivalry among the great capitalist nations U. S. ownership of Canadian manufacturing leads to ... the quantitative and qualitative undermining of [Canada's] manufacturing sector ... thus [in Canada] the term deindustrialization refers ... to the special distorting effects of U. S. ownership of Canadian manufacturing, in particular, U.S. attempts to enhance American employment at the expense of Canada. ${ }^{91}$

According to Laxer, Ontario was a victim of "inter-imperial rivalry." The province directly suffered from American multinationals diverting employment growth and investment to the United States.

The socialist activist and Marxist John Hutchenson wrote in (Canada) Ltd. that the Canadian state was a perpetrator of American dependency. He questioned whether the situation could be alleviated without dislodging the "ruling classes" from power. "The Canadian state is now in the control of the dominant section of the ruling class in Canada," which were in turn controlled by American corporations. For Hutchenson, the country's ruling elite "treasonously" furthered the interests of American capitalists "and by doing so contribute[d] to Canada's further integration into the American empire . . . leading to the disintegration of Canada." The only solution was for "Canadians to demand an independent state... controlled by the working people." ${ }^{92}$ Left nationalists such as Hutchenson continued to claim that Canada had lost its independence, which could only be restored by democratic socialism.

Hutchenson was not surprised that the Trudeau government pursued moderate "half-measures" in addressing the Nixon Shock and the problems of

\footnotetext{
${ }^{91}$ James Laxer and Doris Jantz, "The De-industrialization of Ontario," in (Canada) Ltd.: The Political Economy of Dependency, ed. Robert Laxer (Toronto: McClelland and Stewart, 1973), 149-150. ${ }^{92} \mathrm{John}$ Hutchenson, "The Capitalist State in Canada," in (Canada) Ltd.: The Political Economy of Dependency, ed. Robert Laxer (Toronto: McClelland and Stewart, 1973), 173.
} 
American dependency, a sentiment shared by other left nationalists. He claimed that "since the Liberals have been the agents of special status, it was doubtful that a Liberal government would have even noticed that a fundamental issue of Canada's sovereignty was in the balance." In his review of the preceding decade of CanadianAmerican relations, Hutchenson concluded that, "Canadian governments have surrendered the economy to American control." He added, "the loss of sovereignty has been an inevitable consequence." He had equally damning words for the Nixon Shock: "it is ironic that 'special status' has been ended [in 1971], not by the anger of the Canadian people, but by the measures taken by the American empire to help it digest its other intended victims." 93

Watkins agreed with Hutchenson's assessments and wrote "there is no doubt as to the dominance of American corporate capitalism in Canada, and of its increased in recent decades as a special status within the American Empire." The Nixon Shock and the Vietnam War demonstrated the weakening of American hegemony and the eventual fall of the American Empire. The decline of American hegemony and economic power in turn meant the decline of Canada because the two countries were economically intertwined. For the left nationalists in the early 1970s, it was imperative that Canada became fully independent from the American Empire before the country was dragged down with it.

(Canada) Ltd. made it evident that left nationalists remained committed to advancing socialism as a means of achieving independence. Anti-imperialism had taken on a new sense of urgency. Socialism was necessary for independence.

${ }_{93}$ Hutchenson, "The Capitalist State in Canada," 174. 
Capitalism, even in the form of a mixed-market (reformist) welfare state, was problematic because the American-dominated world economy condemned Canada to dependency. Canadian political parties controlled by the country's continentalistminded elite had resisted any meaningful measures to reverse Canada's dependence on the United States.

\section{Conclusion}

The left nationalist concern with American decline, along with the connected phenomenon of deindustrialization, represented one of the left's primary critiques of Canada's economic and political relationship with the United States. The early 1970s witnessed a transformation in American economic and political power. Initially, the Nixon Shock in 1971 caused significant concern in Canada. All nationalists feared that Canada would suffer from the consequences of American economic decline. To ensure Canada's future prosperity, left nationalists contended that the country had to break away from American dependency. However, with Nixon out of office after the Watergate scandal, President Ford, and later President Carter, sought a realignment of American domestic economic policy and foreign affairs.

For left nationalists, the Nixon Shock revealed that Canada's dependence on the United States had hampered its prosperity. Economic nationalism gained political prominence and left nationalists maintained their position as a vocal camp in the wider nationalist movement. The vision of Canada as an independent socialist country, with an economy controlled by Canadian workers and a foreign policy that 
was independent of the crisis-ridden United States, was not regarded by left nationalists as a utopian dream.

Left nationalists and New Nationalists could not agree on a solution to the country's conundrum of American dependence. Left nationalists insisted that only socialism could ensure Canada's independence from the United States, reverse Americanization, and shield the country from the worst effects of American imperial overstretch and decline. Solutions that were presented by left nationalists, such as socialism and nationalization, were viewed by their New Nationalist critics as too radical and potentially destructive to Canada's prosperity and standard of living. Left nationalists for their part claimed the measures adopted by the Liberal government and advocated by the moderates were insufficient. The question for Canadian nationalists, both left and moderate, was "what can be done?" It was a question made more urgent during the coming energy crisis, which drew attention to Canada's status as a resource hinterland.

What differentiated left nationalists from their moderate counterparts was their anti-imperialist worldview and their desire for Canada to be remade into a democratic socialist political economy. Where Abraham Rotstein advocated more government intervention through functional socialism, he did not view the United States as an empire, nor Canada its colony. In the years of the Nixon Shock and the rise of economic nationalist sentiment, left nationalists increasingly described their political project as premised on anti-imperialism and made efforts to study the political economy of dependency. Left nationalists, when contending with issues of Canada's future had no patience for the "liberal reformism" of the moderates in the 
New Nationalist movement. Canada's current and further economic prosperity was threatened by American protectionism, crisis, and decline. Any tinkering of Canadian capitalism was insufficient. 


\section{Chapter 4: \\ The Politics of Energy, Ecological Independence, and the "End of Canada," 1970-1975}

This chapter continues the theme of the contrasting perspectives of English

Canadian nationalists, in this case with reference to the politics of energy

exportation to the United States. The chapter also charts the rise of ecological

independence, the concern that Canada must maintain sovereignty over its finite

natural resources such as oil, gas, and water. On this issue, left nationalists and New

Nationalists were of the same opinion. Ecological independence was one of the

major unifying impulses in the wider English Canada nationalist movement.

For left nationalists, the energy crisis that began in 1973 resulting from the

"Oil Shock" compounded the problems of Canada's economic dependence on the

United States. ${ }^{1}$ But left nationalists had been concerned with Canada's energy trade

policy before the crisis. Expressing declinist sentiment, Cy Gonick characterized the energy crisis as part of a series of events that revealed the "long descent of the

American Empire." ${ }^{2}$ Left nationalists seized on the issue of the energy crisis as a

vindication of their anti-imperialist agenda and used the energy crisis as an

opportunity to advance their political cause, claiming that Canada's unpreparedness

and vulnerability was the result of poor planning and Canada's status as a resource

\footnotetext{
${ }^{1}$ Canada and other industrialized nations were caught unprepared in 1973 by the four hundred per cent increase in oil prices that resulted from the partial oil embargo imposed on the United States, Canada, the United Kingdom, and Japan by the Organization of Arab Petroleum Exporting Countries (OPEC) to protest their support for Israel in the Yom Kippur War. G. Bruce Doern, and Glen Toner, The Politics of Energy: The Development and Implementation of the National Energy Program (Toronto: Methuen Publications, 1985), 90.

${ }^{2}$ Cy Gonick, "The American Empire: The Long Descent," Canadian Dimension, November-December 1973, 16.
} 
hinterland of the United States. John Warnock went further, seeing the federal government's response to the energy crisis as an example of the "hinterland mentality" that caused underdevelopment and reinforced the metropolis-hinterland relationship of Canada and the United States. ${ }^{3}$ By 1973 the major issues for left nationalists concerned by American dependency was American ownership of the resource sector and Ottawa's willingness to allow the widespread sale of resources to American manufacturers with little concern for long term economic and environmental consequences.

In their study of the politics of energy in Canada during the early 1980s, G. Bruce Doern and Glen Toner referred to the energy crisis of the mid 1970s, particularly the 1973 oil shock, as the "turning point" in the domestic and international politics of energy. For them, the issue of energy exportation was the "key issue" of the 1970s. It was a "summation of the Canadian body-politic, embracing issues of nationalism, regionalism, foreign ownership of the economy, partisan conflict, theories and beliefs about Canada's resource heritage, bureaucratic growth and state intervention, and the realities of international dependence and Canadian-American relations." ${ }^{4}$ The contentious politics of energy compounded issues of regionalism in Canada as governments in Saskatchewan and Alberta sought greater control of resources, making energy a major federal issue. ${ }^{5}$ However, since the export of resources was Ottawa's responsibility, left nationalists

\footnotetext{
3 "John W. Warnock, "Metropolis-Hinterland: The Lost Theme in Canadian Letters," Canadian Dimension, June 1974, 46.

${ }^{4}$ G. Bruce Doern and Glen Toner, The Politics of Energy: The Development and Implementation of the National Energy Program (Toronto: Methuen Publications, 1985), 7.

${ }^{5}$ Ibid., 88-89.
} 
and New Nationalists were not interested in the debates over federal-provincial jurisdiction. All nationalists were concerned with the export of resources, American ownership of the resource sector, and Ottawa's lack of a comprehensive policy towards the sector and the environment.

In Washington, the Nixon administration, already concerned with preserving American economic power and determined to take measures to secure American access to depleting oil reserves, openly viewed Canada's energy resources as part of domestic supply. Nixon's policy towards Canada was to maintain the open door for resources but constrain Canada's ability to produce and export manufactured goods. ${ }^{6}$ This served to expose Canada's position as a resource hinterland for American corporations. Prior to the energy crisis, the Trudeau government indicated its willingness to sell energy to the United States and take advantage of a rise in prices as a means of boosting the economy and trade balance.

Nationalists were also concerned with the exploitation and depletion of Canada's resources, with the naturalist John A. Livingston referring to the issue as "ecological independence." ${ }^{7}$ Ecological independence aimed to advance the cause of preserving Canada's resources and environment. In Livingston's words, ecological independence was part of the wider nationalist movement, calling for "stringent control of primary, non-renewable natural resources... It would require a way of thinking with regard to wild lands and unpopulated regions which is rare in

\footnotetext{
${ }^{6}$ Doern and Toner, The Politics of Energy, 89.

${ }^{7}$ John A. Livingston, "Neo-Nationalism and Ecological Independence: A Personal View," in Independence: The Canadian Challenge, ed. Abraham Rotstein and Gary Lax (Toronto: McClelland and Stewart, 1972), 158.
} 
business and industry ... It would also require rejection of the destructive policies and values with which we have allowed ourselves to become infatuated." He added, "in fact, for our very survival, I feel we have no alternative." ${ }^{8}$ In other words, Canada's future as an independent state depended on the preservation of the country's natural resources. Left nationalists reached a similar conclusion.

Marxist interpretations of international relations maintained their influence among left nationalists during this period, specifically the view of a world system characterized by centre and periphery countries competing for rapidly depleting resources. ${ }^{9}$ James Laxer strongly believed that preserving Canada's resources was synonymous with defending the country's independence. He declared, "one can state without exaggeration that Canadian resources have always played a key role in determining Canada's relations with the outside world."10 Left nationalists such as Laxer feared that the energy crisis would mean the "end of Canada," with the country made into a permanent resource hinterland of a declining American empire. Left nationalist politics, while concerned with the issue of American dependence and decline, had by 1973 coalesced around opposition to a continental energy deal and the proposed Mackenzie Valley Pipeline as a means of advancing a socialist agenda and preserving Canada's independence. A proposed pipeline through the Mackenzie River Valley in the Northwest Territories would help ensure ready American access to Canadian energy resources. For left nationalists, the pipeline

\footnotetext{
${ }^{8}$ Livingston, "Neo-Nationalism and Ecological Independence," 158.

${ }_{9}^{9}$ See Immanuel Wallerstein, The Capitalist World Economy (Cambridge: Cambridge University Press, 1979).

${ }^{10}$ James Laxer, The Energy Poker Game (Toronto: New Press, 1970), 16.
} 
embodied the problem of exploitation of Canada's resources by the United States and was a direct threat to Canada's ecological and economic independence.

Left nationalists interpreted the energy crisis as resulting from an acute competition for resources, which were being rapidly depleted due to capitalist consumption and exploitation. However, there was a division amongst left nationalists over the specific causes of the energy crisis. Laxer believed it to be the result of capitalist imperialism and the contradictions of capitalism, while others such as Mel Watkins held that the crisis was primarily caused by the result of the depletion of resources. Both, however, agreed that the consequences for Canada were dire. For left nationalists, the solution to the problem of American dependency remained the same: socialism would preserve Canada's economic and ecological independence and shield it from the crises of capitalism and American imperialism.

\section{The Continental Energy Deal}

Gonick was a regular critic of Canadian energy and trade policy with the United States, claiming it was a clear representation of Canada's status as a colony in a declining American empire. Reflecting on decades of continentalist energy policy, Gonick believed that Canada was a willing partner of the United States and that the Canadian government was an agent of continental energy policy. In November 1973, Gonick described Ottawa's strategy as insufficient because it was clear there would be no reduction in the sale of resources to the United States. Perhaps, Gonick 
speculated, Ottawa was complicit in a "plot to annihilate Canadian resources." 11 As he saw it,

a powerful alliance of vested interests has emerged to actively campaign for each and every project that aims to sell Canadian resources to the United States. These include multinational corporations who sponsor the projects; the banks and finance companies that help finance them; the railway and pipeline companies that carry the resource products to American markets; the local businessmen and chambers of commerce in northern communities that profit from any new activity in their region; and the federal and provincial governments who are prepared to invest vast amounts of public money to support private developers. ${ }^{12}$

Gonick believed that Canada would be foolish to tie its fortunes to the crisis-ridden Americans, but that Ottawa was unwilling or unable to come to this realization because of a hinterland mentality. ${ }^{13}$ The continental energy market indicated how Canada was a resource hinterland dependent on the United States. Contributors to Canadian Dimension insisted that Canada's status as a resource hinterland was one of the most pressing examples of the problems of the staples trap and American dependency.

Nationalists and continentalists agreed that preserving Canada's resource wealth was important to the country's long-term prosperity. However, continentalists insisted that Canada had a resource surplus (in oil and gas, minerals, lumber, and water) that was not at risk of depletion. Canada's wealth was based on the sale of these resources, with the money going into the development of the wider economy. Energy Minister J. J. Greene was of that mind when in December 1969 he welcomed the prospect of a continental energy deal that would potentially entail

\footnotetext{
${ }^{11}$ Gonick, "The American Empire," 20.

12 Ibid., 21.

13 Ibid., 16.
} 
free trade in energy resources and permanent continental integration of the sector, remarking that Canada's prosperity was directly tied to trade and called a continental energy policy "extremely interesting." 14

Left nationalists were strongly opposed to Greene's continentalist energy policies, which they viewed as a threat to Canadian sovereignty. Greene became an easy target of the left nationalists when he declared his opposition to the economic nationalist agenda, claiming that, if the nationalists got their way and the country retained total control and full ownership over its resources, Canada would become an impoverished "banana republic." 15 He also claimed that a continental energy deal would "benefit both countries, irrespective of where the imaginary border goes." 16 Nationalists vehemently disagreed, and Greene was immediately made out by Laxer as the villain in a cast of characters that were selling Canada to the United States. ${ }^{17}$ The Toronto Star's editors were also alarmed and responded with an editorial that described Greene's words as "unnerving” and insisted that Canada's economy must "be protected from any further U.S. encroachment if Canada is to maintain and strengthen its control over its economic and political destiny."18 The United States only had its own interests to protect. It was not in Canada's national interest to have its resources exploited by the United States. ${ }^{19}$

\footnotetext{
${ }^{14}$ J. L. Granatstein and Robert Bothwell, Pirouette: Pierre Trudeau and Canadian Foreign Policy (Toronto: University of Toronto Press, 1990), 82.

15 “U.S. Invites Canada to Pool Oil, Gas, Hydro," Toronto Star, 5 December 1969, 2.

16 J. J. Greene, quoted in James Laxer, "The Alienation of Canada's Resources: An Overview," Canadian Dimension, Jan.-Feb. 1971, 11.

${ }^{17}$ Laxer, The Energy Poker Game, 13.

18 "We're Not For sale," Toronto Star, 6 December 1970, 6.

${ }^{19}$ During the winter of 1970-1971 Canada increased its exports of natural gas to the United States. Twelve trillion cubic feet of gas per year was supplied to the United States. Minister Greene agreed to export an additional 6.3 trillion cubic feet. This represented approximately one third of the Canadian
} 
Mel Watkins was disturbed by Greene's musings about a continental pact, believing that it would involve a commitment by Ottawa to regard Canada's resources as continental, and give up on any plans for developing them "outside the framework of American corporate or military interests." 20 Watkins regarded an energy deal with the United States as a threat to Canadian sovereignty, since Canada would "cross a threshold in our relations with the United States that would be extremely difficult to re-cross ... [with] ... real sovereignty in deciding power residing with the U. S. government and corporations." 21 Watkins' fears were not unreasonable, since Greene had earlier claimed that the federal and provincial governments were happy to cooperate in expanding the continental energy market.

Left nationalists were given further cause for alarm when a United States Cabinet task force issued the Schultz Report in February 1970. It assumed Canada to be a safe, if not the safest, foreign source of energy. The report stated: "[t]he risks of political instability or animosity is generally conceded to be very low in Canada. The risk of physical interruption or diversion of Canadian oil to other export markets in an emergency is also minimal for those deliveries made by inland transport."22 The Report called for "common or harmonized policies with respect to pipeline and other modes of transportation, access to natural gas, and other related energy

total gas assets. Richard Rohmer, The Arctic Imperative: An Overview of the Energy Crisis (Toronto: McClelland and Stewart, 1975), 77.

${ }^{20}$ Watkins, "Introduction," in James Laxer, The Energy Poker Game: The Politics of the Continental Resource Deal (Toronto: New Press, 1970), 1.

${ }^{21}$ Ibid., 2.

22 The Oil Import Question: A Report on the Relationship of Oil Imports to the National Security, Cabinet Task Force on Oil Import Control, Washington, D.C (Washington D.C.: U.S. Government Printing Office, 1970), 424. 
matters." 23 This confirmed what many Canadian nationalists had complained about for years: that "the economic infrastructure of the United States is and can be more integrated with Canada than with the economy of any other country in the Western Hemisphere."24

In his review of the Shultz Report, Laxer was particularly alarmed by its estimate that for every American dollar invested in Canada in the future, seventyone cents would return to the United States in the form of profits or purchases within the first year of the investment being made. ${ }^{25}$ Laxer's fears were warranted. In response to the report, President Nixon announced a fixed quota on oil imports from Canada, which he justified in the name of national security. In addition, Nixon proposed a study on the integration of the North American energy market. ${ }^{26} \mathrm{~A}$ clearer representation of the Canadian-American empire-colony relationship could not have been made.

American Secretary of the Interior Walter Hinkel confirmed that the Nixon administration aimed to have a continental energy deal proposal ready as soon as possible. The United States Federal Power Commission found that the use of natural gas had outstripped the discovery of new reserves, and American power companies were increasingly turning back to coal as a source of electricity. ${ }^{27}$ Laxer saw Canada's sovereignty threatened because of increased pressure in Washington to

${ }^{23}$ The Oil Import Question, 121.

24 Ibid.

${ }^{25}$ James Laxer, "The Greene-ing of Canada," in Independence: The Canadian Challenge, ed. Abraham Rotstein and Gary Lax (Toronto: McClelland and Stewart, 1972), 146.

${ }^{26}$ Vilma L. Kohn, "The Oil Import Question: Research, Report, Reaction," Case Western Reserve Journal of International Law 3, no. 1 (1970), 101-2.

${ }^{27}$ Laxer, "The Greene-ing of Canada," 142. 
secure energy supplies ${ }^{28}$ and noted the growing insecurity of American oil and gas investments in the Middle East and Latin America. ${ }^{29}$

James Laxer, true to his anti-imperialist beliefs, condemned the federal government's approach, calling it "a strategy for turning Canada into a permanent resource hinterland of the United States, a country bound to be economically and politically dependent." Laxer was worried that Canada would lose its political freedom to deviate from American foreign policy if Canada was made a permanent source of American strategic resources. An energy deal was viewed by Laxer as giving an opening for American multinationals to "tighten their grip" on Canada. ${ }^{30}$ The United States would not tolerate any threat to its Canadian energy supply. In an editorial in Canadian Dimension, Laxer lambasted the proposed continental energy deal and accused the Liberals of being continentalists, complicit in the sell-out of Canada's resources to the Americans.

Nixon did not allay fears that the Americans would take control of the Canadian energy market with his claim, quoted by Laxer, that "a unique degree of security can be afforded by moving toward an integrated North American energy market." 31 Canada, an ally with abundant natural resources, and with federal and provincial governments eager to sell them, aided the Nixon administration's quest for energy security. If one held to Laxer's line of reasoning, the energy crisis made

\footnotetext{
28 There was domestic pressure to secure more energy supplies. During the summer of 1970 there were widespread electricity blackouts and brownouts in the United States that were blamed on the widespread use of air conditioners during a prolonged heatwave.

${ }^{29}$ Laxer, "The Greene-ing of Canada," 143.

${ }^{30}$ Ibid., 150.

${ }^{31}$ James Laxer, “Editorial: Continental Energy: A Proposal," Canadian Dimension, April-May 1970, 5-6.
} 
the United States dependent on Canadian energy. ${ }^{32}$ This was a troubling development for left nationalists because they feared a continental energy deal would place Canada and the United States in a mutual dependency that would be impossible to break.

Unease about Ottawa's approach to Canada's economic relations with the United States was not limited to left nationalists. Members of the Trudeau cabinet also expressed misgivings. Eric Kierans, the Minister of Communications, was a recent convert to economic nationalism. Ottawa's lack of action in combating foreign investment and its position of energy exports to the United States led him to resign from the cabinet in April 1971. His resignation letter to Prime Minister Trudeau outlined his concern about global interconnectivity and his nationalist stance in that context.

The rise of the international corporation is leading some economists and businessmen to talk in terms of Gross World Production rather than Gross Domestic Product as a better index of economic growth... One can detect the implicit assumption that Canada is to be assigned the role of supplier of resources permanently because we have them, and also because we do not have a sufficient domestic market to justify their conversion into finished or semi-finished products here at home. ${ }^{33}$

Kierans also expressed apprehension about the future prospects of world economic growth and the exploitation of non-renewable resources. He wrote that "economic growth is not unlimited. Even with exponential increases in capital and population three billion now, six billion by 2000, a diminishing supply of non-renewable

\footnotetext{
32 The United States was never dependent on Canada exclusively, but dependent on foreign sources. Canadian oil and gas exports to the United States in the early 1970 s represented only $5 \%$ of the American supply. Philip Sykes, Sellout: The Giveaway of Canada's Energy Resources (Edmonton: Hurtig Publishers, 1973), 14.

${ }^{33}$ Eric Kierans, "Letter to Pierre Trudeau," April 28, 1971, Eric Kierans Fonds MG 23 B 10, vol. 1, file 15.
} 
resources will restrain world growth." Canada needed to adopt policies to invest in physical and human resources in a way that would be sustainable and ensure prosperity. ${ }^{34}$

Kierans, an economic nationalist who later joined the New Nationalist cause, was primarily concerned with the export of Canadian resources to the United States. ${ }^{35}$ He was commissioned in 1973 by the Manitoba NDP government of Ed Schreyer to study the ownership of the mining industry. He recommended public ownership of the mining sector. He wrote: "It's not a question of capitalism or socialism ... the landlords of Manitoban resources are Manitobans."36 But Kierans was not a left nationalist, despite his concern with foreign investment and the exploitation of natural resources and his view that the world was heading to decline if it continued its present rates of resource exploitation.

James Laxer published The Energy Poker Game in 1970. The book was intended as a means of rallying support against increasing energy trade with the Americans and to bolster his campaign for leadership of the NDP. Laxer expressed his anti-imperialist and Marxist worldview. "One can state without exaggeration," he wrote, "that Canadian resources have always played a key role in determining Canada's relations with the outside world." 37 That made Canada a resource

\footnotetext{
${ }^{34}$ Kierans, "Letter to Pierre Trudeau."

${ }^{35}$ Immediately after Kierans' resignation from cabinet, Walter Gordon invited him to join the Committee for an Independent Canada (CIC), assuring him that it was in "no way radical." The CIC was concerned about the exploitation of Canada's resources mostly by foreign entities. In its statement of purpose, the CIC urged that "governments at all levels must become more active in the fight against pollution, even when cleaning up our own environment infringes on vested interests. This emphatically includes the protection of Canadian jurisdiction in the Arctic." Walter Gordon,

"Letter to Eric Kierans," Eric Kierans Fonds MG 23 B 10, vol. 1, file 15.

${ }^{36}$ Donn Downey, "Eric Kierans, 90," Globe and Mail, May 10, 2004.

${ }^{37}$ James Laxer, The Energy Poker Game (Toronto: New Press, 1970), 16.
} 
hinterland colony at the mercy of an American empire. "We have always been a subordinate people; derivative people, because of our origins and our history as resource exporters. Our staples products have been the real chains of empire that have bound us first to Britain and now to the USA." ${ }^{38}$ Canada's role as a middle power was a fallacy. Canada was an American colony and the Commonwealth had declined into irrelevancy. Laxer believed Canada's foreign policy “turned on moral gestures, which usually consist of minor criticism of the Americans within a context of almost total support for their policies in the world." Canada's foreign policy was driven by its resource wealth. "Our involvement in the Vietnam War has much more to do with the metal and the guns we sell than with our presence [as peacekeepers] on the International Control Commission ... Oil is more important than peacekeeping." 39 In this view Canada, as a colony, only had one real purpose: supplying resources to the American core.

Laxer believed Greene's comments on an energy deal as a means of overcoming "imaginary borders" and revealed the Liberal government's wider continentalist energy trade agenda. An energy deal would worsen the situation, moving the country into a greater state of dependency on the United States, and making Canada more of a periphery economy. ${ }^{40}$ The continentalization of Canada's resources ensured the continuation of an economy based on "hewing wood and drawing water." This meant "accepting colonialism as a permanent status for

\footnotetext{
${ }^{38}$ Laxer, The Energy Poker Game, 16.

39 Ibid., 17. Canada, along with India and Poland, was a member of the International Control Commission which was established in 1954 and was tasked with overseeing the Geneva Accords and the ceasefire between North and South Vietnam.

${ }^{40}$ Ibid., 22.
} 
Canada," and becoming a "resource hinterland to the world's most powerful state." Canada would cease to exist, having suffered from "political and social disintegration." 41

Left nationalist opposition to selling Canada's resources to the United States was a major component of the Waffle's political program as early as 1970. The Waffle viewed the Liberal government's position on a potential energy deal as either complicit in or oblivious to colonialism as a "permanent status for Canada." ${ }^{2}$ In supporting a continental energy deal, the Liberals were accepting that "short run desire for profit should remain a key determinant of the allocation of resources," leading to environmental destruction. ${ }^{43}$ In a pamphlet distributed to rally support for protests against a continental pact, the Waffle used Marxist language and described the fight against the selling of resources as part of the anti-imperialist struggle. For the Waffle, any deal to supply the United States with Canadian resources on a permanent basis would "wipe out the Canadian-American border." 44 Tying the trade of resources to Canadian foreign policy, the Waffle declared, "Canadians will continue to be ruled by giant private corporations, both Canadian, and foreign. Our resources will be used on an ever-larger scale to feed the American military machine that is killing and maiming the people of South-East Asia who are seeking self-determination." The Waffle went further and attempted to rally support from the fledging environmentalist movement, declaring that the deal "involves the

\footnotetext{
${ }^{41}$ Laxer, The Energy Poker Game, 17.

42 “Canada-Wide Protests vs. Energy Deal." Waffle News, Sept 12, 1970.

${ }^{43}$ Ibid.

${ }^{44}$ Waffle Group, "Stop the Continental Energy Resources Deal," CCF/NDP Fonds MG 28 IV-I, vol. 446, file 7.
} 
rape of the environment." 45 Environmental degradation and resource depletion was inexorably linked to Canada's trade in energy to the United States. For left nationalists, it embodied the exploitative Canadian-American colonial relationship.

Left nationalists pointed to opinion polls, such as the May 1973 Gallup poll that showed forty-eight per cent of Canadians were in favour of nationalizing the resources sector, as evidence that rising nationalist sentiment led to a rise in support for socialism. ${ }^{46}$ Bowing to public pressure, Minister Greene reversed his opinion on the positives of a continental energy deal, and embraced a nationalist stance. At an address to the Independent Petroleum Association, Greene declared his opposition to a continental energy deal. However, he assured his audience that Canada's energy exports remained available for export and made it clear that Canada wanted Americans to buy its oil. According to Laxer, "[Greene's] tough bargaining point was this: you Americans cannot have our natural gas, unless you take our oil as well." 47 The sale of natural resources was "part of the free enterprise road to Canadian prosperity." 48

The Schultz Report, and speculation about a continental energy deal, provided Laxer with an opportunity to advance a left nationalist political agenda that aimed to use socialism as a means of reversing Canada's status as a resource hinterland. Canada's politics were "suffocated" by a hinterland mentality, represented by the muted response by the Canadian political establishment to the

\footnotetext{
45 Waffle Group, "Stop the Continental Energy Resources Deal."

${ }^{46}$ James Laxer, "The Greene-ing of Canada," 139.

${ }^{47}$ Ibid., 140.

48 Ibid., 141.
} 
question of the energy resources deal. Urging a radical shakeup of Canadian politics Laxer declared that "our political system is so attuned to dependency that it cannot but be prosaic in the face of events which will shape the entire future of the Canadian people." He identified an opening for left nationalism: "the fact that there is little instinct for self-preservation in established Canadian politics reveals how close the system is to the graveyard." Laxer was hopeful that a continental energy deal would result in a political backlash in English Canada which would "sweep aside the old political system." The continentalization of Canada's energy resources bolstered the cause of left nationalism, or what Laxer called "anti-imperialism." Failure to embrace a left nationalist agenda meant "almost total political powerlessness of Canadians as they are doomed to life in a permanent hinterland." 49 However, Laxer was outmaneuvered by Greene's backtracking on the issue of a continental energy deal. While the New Nationalists now appeared to be in control of the agenda, Laxer insisted that left nationalists needed to maintain political pressure. ${ }^{50}$ The choice was clear: embrace the left nationalist agenda or resign Canada to its fate as a colony of the United States.

\section{Ecological Independence}

Left nationalist and New Nationalists tied Canada's resources to its national survival and ecological independence. Preserving Canada's resources, especially water, was imperative to the maintenance of the country's independence and

\footnotetext{
${ }^{49}$ Laxer, Energy Poker Game, 44-45.

50 Ibid., 45.
} 
ensuring its very existence. Journalist Walter Stewart was sympathetic to the New Nationalist cause and was a regular critic of what he saw as Ottawa's inability, or unwillingness, to confront the problem of the "sell-out" of Canada's resources to the United States. Stewart was alarmed by Prime Minister Trudeau's musings in March 1970 about selling water to the United States. ${ }^{51}$ In response, Stewart wrote an article in Maclean's titled, "Water: The Sellout that Could Spell the End of Canada." Stewart believed that it was imperative that Canada's water resources be preserved. He insisted that selling water to the United States threatened Canada's sovereignty because it would "link our resources irrevocably to American needs. Export is a tap that, once turned on, could never be shut off again." 52

Canada's water resources held a special symbolism since it was an abundant resource that was not owned by multinational corporations or exported. Stewart feared that American demands for Canadian water would only increase in the future, placing Canada under strong pressure to supply the United States. This would mean that "our development, our prosperity, [and] our sovereignty will disappear one dusty day down an American drain."53 Stewart's comments represented the sentiment of ecological independence. Canada's resource wealth was crucial to the country's prosperity.

Nationalists had long held special regard for Canada's water resources. Many placed the country's waterways and hydro resources at the centre of the country's

\footnotetext{
51 On Canada's water resources, Trudeau asked, "if people aren't going to use it, can't we sell it for good hard cash?" Quoted in Walter Stewart, "Water: The Sellout that Could Spell the End of Canada, "Maclean's, March 1970, 44.

52 Ibid.

53 Ibid.
} 
national identity. As an example of this sentiment, the 1961 Columbia River Treaty was regularly dismissed by nationalists as a sellout of Canada's interests because the river was diverted largely to the benefit of American hydroelectricity production. As an example of the opposition against the treaty, Laxer called it a "standing invitation to the U.S. to regard Canadian water as American water." General Andrew McNaughton, the former Canadian chair of the International Joint Commission, held a similar view. ${ }^{54}$ The treaty sparked speculation by American corporations that other Canadian waterways could be utilized for similar purposes. Nationalists grew irate when immediately after the ratification of the treaty American corporations ${ }^{55}$ proposed diverting the Mackenzie River south to the United States by digging a trench through the Rockies. Proponents of selling Canadian water viewed it as a continental resource that must be sold with the Americans for a good profit. Nationalists were understandably wary of schemes to sell Canadian water in the early 1970s.

Environmental concerns, while not the main component of ecological independence, remained a major concern for many nationalists. In 1972, Richard C. Blocking, a producer for CBC television, presented his views on defending Canada's water resources in Canada's Water: For Sale. He was concerned with unrestrained economic growth which he believed threatened Canada's environment. For

\footnotetext{
54 The International Joint Commission (IJC) is responsible for interpreting the Boundary Waters Treaty (1909) between Canada and the United States. McNaughton believed his opposition to the Columbia River treaty led to his dismissal from the IJC in April 1962. General Andrew McNaughton, "The NAWAPA Scheme and Canadian Sovereignty," Canadian Dimension, July-August 1966, 20. 55 The California-based Ralph M. Parsons Company and the American Power and Water Alliance proposed the diversion scheme and were clear that its sole intention was to supply the American south-west with an unlimited supply of fresh water. McNaughton, "The NAWAPA Scheme," 20.
} 
Blocking, the diversion of Canadian waters to the United States was not only a threat to the country's sovereignty, but it would also mean ecological destruction that would negatively affect the economy. Blocking also suggested that diversion of waterways and the export of water would destroy Canada's "national character." Canada's national identity was tied to its ecology. "Canada is a product of its land," Blocking wrote, "and dependent on the integrity of the land for survival." ${ }^{56}$ Canada was built upon its waterways which stretched east to west. In alarmist terms, Blocking claimed their destruction would mean the end of Canada. Diverting rivers to benefit the United States would remove the "east-west basis" of Canada's existence, and represent surrender to the United States. ${ }^{57}$

Ecological independence formed a critical component of Laxer's left nationalist agenda. He viewed the energy crisis as a turning point for Canada. He referred to ecological concerns and expressed a nascent environmentalism to illustrate further the peril that Canada faced.

It now becomes clear that the dependency of Canada leads to not a quieter life in our corner of the world, but to a transformation of the environment itself, which turns our country into a giant supplier for the industrial system of the United States. . [and] potentially immense damage to the environment as our oil and gas and water is removed from the north with its delicate ecological systems. ${ }^{58}$

In characteristically bombastic terms, Laxer declared that the problem of coming to terms with environmental issues caused by energy exploitation "will not be solved for America through the rape of Canada." ${ }^{59}$ Canada's relationship with the United

\footnotetext{
${ }^{56}$ Richard Blocking, Canada's Water: For Sale? (Toronto: James and Lewis, 1972), 45.

57 Ibid., 166-7.

${ }^{58}$ Laxer, The Energy Poker Game, 46.

${ }^{59}$ Ibid.
} 
States was existential, and the energy crisis put the country in peril. Laxer did not waste an opportunity to stress the urgency of his political program. He insisted that a left nationalist agenda that pursued public ownership of resources was the only political means of securing ecological independence. He concluded that "A new Canada and a new politics will be born out of the struggle that must be joined to make possible a society in which our resources serve people both at home and abroad and in which the people who work in the industries of the country determine the direction of the economy and receive its benefits." 60

At the same time, in 1972 on the eve of the energy crisis, the Club of Rome (COR) published The Limits to Growth, ${ }^{61}$ a report on the consequences of the depletion of natural resources and continued population growth. Nationalists not associated with the left such as Eric Kierans, who were worried about Canada's ecological independence and the preservation of its resources, were given cause for alarm. Kierans, who was in regular correspondence with the COR, worried about the implications for Canada since it was one of the world's top suppliers of nonrenewable resources. ${ }^{62}$ The COR was a research group made up of leading economics and "futurologists" concerned about the "trajectory of mankind." 63 Of particular concern was the consumption of non-renewable resources and unsustainable population growth. Earlier in 1970, a team of researchers at the Massachusetts Institute of Technology commissioned by the COR had run a series of

\footnotetext{
${ }^{60}$ Laxer, The Energy Poker Game, 45-6.

61 The Club of Rome, The Limits to Growth: A Report for the Club of Rome's Project on the Predicament of Mankind (Washington: Potomac Association Books, 1972).

${ }^{62}$ Eric Kierans, "Woodward Lecture," University of British Columbia, 1972, Eric Kierans Fonds MG 23 B 10, vol. 5, file 2 .

63 The Club of Rome, The Limits to Growth, 9-10.
} 
computer simulations that examined agricultural production, population growth, non-renewable resource consumption and production, and industrial output and pollution. According to their projections, resource depletion would limit economic growth, beginning in 2000 with the world unable to support its projected population by the middle of the twenty-first century. In the immediate term, conventional supplies of oil were expected to be exhausted by 2000.64

For left nationalists, The Limits to Growth's conclusions were more threatening for Canada, since they believed the country was rapidly becoming a site of resource exploitation by the United States. It was feared that Canada would quickly lose control of its resources at the hands of exploitative multinationals and a grasping United States. Once energy resources were depleted, conventionally understood as a near-term problem, Canada's economy and nationhood would be permanently damaged. Growing concern about the finite supply of energy resources and the global competition to secure them led left nationalists to worry about Canada's place in a world order increasingly defined by powers competing for control of rapidly depleting energy resources. The risk posed by Canada's submissive relationship with the United States was intensified, as Canada's natural resources, the foundation of its economy, faced depletion.

Kierans, then a backbencher, opposed the Trudeau government's proposed Foreign Takeovers Act. In a June 5, 1971, speech to the House of Commons, Kierans outlined his moderate economic nationalist credentials and also demonstrated his sympathies with some of the viewpoints held by the left. Kierans reminisced about

\footnotetext{
64 The Club of Rome, The Limits to Growth, 125-6.
} 
his attendance at a conference at New York University which discussed the rising tide of nationalism globally and opposition to multinational corporations. It was at that conference that Kierans realized the inadequacies of the proposed Foreign Takeovers Act. He claimed representatives from the headquarters of Standard Oil and IBM expressed no concern with the act and were in fact surprised by Canada's moderate approach to the issue of foreign ownership. To make matters worse, Kierans discerned from the conference that Canada was regarded as an example of what not to do with regards to preventing large scale foreign investment. This gave credence to the left nationalists' claim that Canada did face a problem of political economy and was too eager to receive foreign investment. ${ }^{65}$ Kierans believed that technological advancement would solve the problems of exploitation of nonrenewable resources and future growth limits that Canada and the world faced. Kierans' faith in technology set him apart from left nationalists, who were increasingly of the opinion that ecological conservation was the only way to stave off the dire projections presented in Limits to Growth, and the inevitable depletion of Canada's resources.

In a lecture at the University of British Columbia, Kierans expressed concern about the newfound power of the multinational corporations, claiming they had a high social cost, and accusing governments of abandoning their responsibility to the public to ensure social and economic growth. He believed the situation could be reversed if the power of exploitative corporations were reduced. Kierans' outlook

${ }^{65}$ Eric Kierans, "Speech to House of Commons on Foreign Takeovers Act," House of Commons Debates, 2846, Eric Kierans Fonds MG 23 B 10, vol. 5, file 2. 
was similar to that of the left nationalists who viewed multinationals as a threat to the long-term prosperity of Canada and the sovereignty of nations. In his view, it was imperative that the growth and power of multinationals be curtailed. In Canada's case it was apparent that more resources and capital were being drained off than were being invested, postponing the day when Canada would become "selfsufficient and responsible for its growth."66

Amidst all the national fervour, and under pressure from the NDP which held the balance of power in the House of Commons, the Trudeau government eventually took action on the energy file. In December 1973 Ottawa announced the creation of Petro-Canada as a compromise between those advocating the maintenance of the status quo and those on the left demanding nationalization of the oil industry. ${ }^{67}$ While the energy crisis may have presented Ottawa with the perfect opportunity to intervene and nationalize the industry, the federal government was reluctant, in part out of fear of angering the Americans, and opted instead to create a Crown Corporation that competed in the oil extraction and gasoline distribution business against multinationals. ${ }^{68}$ This seemed to vindicate the left nationalists, since it revealed the extent to which Ottawa was reluctant to confront the United States. They believed that the energy crisis reinforced how very little control Canada had over its own resource markets.

\footnotetext{
${ }^{66}$ Eric Kierans, "Woodward Lecture."

${ }^{67}$ John Erik Fossum, Oil, the State, and Federalism: The Rise and Demise of Petro-Canada as a Statist Impulse (Toronto: University of Toronto Press, 1997), 81-82.

68 David J. Blair, "Energy Security and Canadian Energy Policy: Independent versus Collective Action," Journal of International Studies 11, no. 2 (June 1982), 130-31.
} 
During the energy crisis, New Nationalist commentators continued to make the case that Canada was overly dependent on diminishing resource wealth. In his contribution to Gary Lax's and Abraham Rotstein's edited work, Getting it Back: A Program for Canadian Independence, the scientist and president of the Edmonton Chapter of the Committee for an Independent Canada, J. C. Russell, claimed that Canada's reliance on resource wealth compounded the problem of Canadian political economy. Russell contended that the resource sector's practices were the main cause of Canada's problem of underdevelopment. Repeating the common refrain of left nationalists influenced by dependency theory, Russell argued that over-reliance on energy and resource extraction led to lower spending on research and development compared to a decade before, and unemployment and underemployment were at levels that "would not be tolerated in other industrialized economies." ${ }^{69}$ He believed future prospects for Canada were grim because its oil supply would soon be exhausted. Russell cited reports claiming that Canada had only twenty years' worth of remaining oil supply because of high domestic consumption and fifty-five per cent being exported to the United States. ${ }^{70}$

Russell's skepticism of the potential of the tar sands to alleviate the oil supply crisis reflected left nationalists' concern with Canada's integration into a continental energy market. Russell assumed it was impossible to develop the tar sands using conventional methods, believing that in order to supply the domestic market, a city

${ }^{69}$ J. C. Russell, "Earth, Fire and Water: Towards a Policy for Energy Resources," in Getting in Back: A Program for Canadian Independence, ed. Gary Lax and Abraham Rotstein (Toronto: Clark, Irwin, 1973), 99.

70 Ibid. 
the size of Montreal would have to be built at Fort MacMurray. Large quantities of hydrogen derived from natural gas were needed to convert the tar into synthetic crude oil, which was not feasible because of the shortage in global supplies of natural gas. Nor was Russell hopeful about claims of future supplies in the Athabasca tar sands being made available through near-term advances in technology. Canada was at the mercy of American multinationals. ${ }^{71}$

Opposition to, and skepticism about, the Athabasca tar sands intensified among left nationalist commentators in the mid 1970s. Waffle supporter Larry Pratt, writing in Canadian Dimension, viewed the tar sands as an example of the costs of a Canadian state capitalist system dependent on the United States. Pointing to the Syncrude deal of February 1975 (the first major tar sands extraction investment), Pratt held that the deal was

... in the great tradition of Canadian state capitalism [as] the huge sums of public money to underwrite the costs of massive resource extraction projects controlled by foreign capitalists is not exactly a historic innovation; essentially we are putting up well over a billion dollars to facilitate the expansion of the American petroleum industry into a new and costly energy source. ${ }^{72}$

The Syncrude tar sands project faced immense cost overruns and would have collapsed if not for government tax subsidies and the promise of increased demand for oil. ${ }^{73}$ For the project's critics, such as Pratt, it was another example of how the federal and provincial governments acted at the behest of American corporate interests. Pratt later expanded on these points in his book, The Tar Sands: Syncrude

\footnotetext{
${ }^{71}$ Russell, "Earth, Fire and Water," 99.

72 Larry Pratt, "The Canadian State as Agent of Foreign Corporations," Canadian Dimension, March 1975, 28.

${ }^{73}$ Blair, "Energy Security and Canadian Energy Policy," 134.
} 
and the Politics of Oil, where he expressed continued opposition to the continental integration of the energy sector and argued that the Canadian state subsidized the tar sands for the benefit of the American energy sector. He also expressed antiimperialist sentiment when opposing the global integration of the energy market, writing that the International Energy Program ${ }^{74}$ was an instrument of American domination..$^{75}$ For Pratt, developing the tar sands was indeed costly and served to further integrate Canada into a continental energy market and threatened ecological independence.

Left nationalists viewed state subsidies of mostly American owned multinational corporations developing the energy sector, of which Syncrude was just one example, as evidence of Ottawa's willingness to integrate itself into the "American empire." Despite having more domestic supply than other industrialized nations, Canada was not immune to price fluctuations because the oil industry was primarily foreign-owned, and responsive to shifts in the American market. Canada, and the world, relied heavily on rapidly diminishing energy resources. Canada's economic prospects were hampered by its reliance on wealth derived from energy exports, threatening its long-term economic prospects and energy reserves.

\footnotetext{
${ }^{74}$ Canada joined the United States, Japan, and the European Economic Community at the February 1974 Washington Energy Conference that resulted in the creation of an International Energy Agency to coordinate energy policies between the participant countries. Ibid., 132-33.

${ }^{75}$ Larry Pratt, The Tar Sands: Syncrude and the Politics of Oil (Edmonton: Hurtig Publishers, 1976), 186.
} 
The Mackenzie Valley Pipeline and the "Resource Sellout"

In April 1972, at the height of the debates over a continental energy deal and a year before the energy crisis, the Trudeau government announced the Mackenzie Valley Pipeline. Ottawa justified the pipeline as an important project for developing the North and expanding access to Canada's energy resources. In addition to the pipeline, the government proposed an all-weather highway from Alberta to the Arctic Sea coast along the Mackenzie River Valley. Indian Affairs and Northern Development Minister Jean Chrétien hailed the highway as an example of the government's commitment to developing the North, promising it would be the first step in creating an energy and communications corridor through the valley. ${ }^{76}$ On the surface it appeared that Ottawa was fulfilling a longstanding national dream of opening the North to development. What was not clear, however, was whether this northern development encompassing highways, telecommunications links, and a natural gas and oil pipeline through the Mackenzie Valley would be in the national interest. Left nationalists suspected that the development would be for the benefit of Americans and undertaken by American multinationals.

The debate over the proposed Mackenzie Valley Pipeline quickly emerged as an important part of the left nationalists' opposition to Canada's further integration into a continental energy market. Left nationalists claimed that Ottawa's enthusiasm for an American-backed pipeline revealed the extent to which Canada was a resource hinterland of the United States. They believed the Mackenzie Valley

${ }^{76}$ John Warnock, "The Mackenzie Valley Pipeline: A \$5 Billion Disaster," Canadian Dimension, October 1972, 35. 
Pipeline was the embodiment of all the dangers of American dependency. As an indication of this sentiment, the Waffle activist, and Marxist John Warnock opposed any pipeline construction through the Mackenzie Valley, believing that it would increase the likelihood of the United States gaining control of energy reserves in the Canadian North. ${ }^{77}$ He insisted that Ottawa was advocating the construction of the pipeline on behalf of American interests. There was evidence that supported his claims. The consortium formed to finance the pipeline consisted of ten corporations, only four of which were Canadian, and only one, Canadian National Railways, was free of foreign influence. Warnock contended that Ottawa, in supporting the pipeline, was acting for the American energy market. ${ }^{78}$

The Liberal government, for its part, anticipated opposition and sought to address concerns that the newly formed consortium was not sufficiently Canadianowned. To mitigate fears that the pipeline would be heavily American-owned and financed, Ottawa blocked the American corporation Panarctic Oil from having a share of ownership or control of the pipeline and announced that the Canada Development Corporation would buy stock in the pipeline. Finance Minister Donald Macdonald further announced that Canadians would own fifty per cent of the consortium's equity stock. But, the moderate economic nationalist Ian Wahn, author of the Wahn Report and Chairman of the Standing Committee on Defence and

\footnotetext{
77 Warnock, while primarily concerned with the pipeline leading to further American penetration into the Canadian energy industry, was also worried about the effects the pipeline would have on Indigenous peoples and the environment. He wrote: "construction of the pipeline will pose problems of environmental damage, exploitation of the area's Native people, and ownership and control and economic impact." John Warnock, "The Mackenzie Valley Pipeline: A \$5 Billion Disaster," Canadian Dimension 9, October 1972, 35.

${ }^{78}$ Ibid., 39
} 
External Relations, expressed misgivings about the government's plans to Canadianize the consortium. Wahn did not want foreigners to own shares in the consortium building the pipeline and did not believe Macdonald's plan was sufficient as shares could be dispersed among American corporations, resulting in the consortium being less than fifty per cent Canadian-owned. ${ }^{79}$

Of all the left nationalists, Mel Watkins devoted the most attention to opposing the Mackenzie Valley Pipeline, which he argued represented the problems of Canadian political economy, such as the staples trap and resulting underdevelopment. He viewed the fight against the Mackenzie Valley Pipeline as being on the frontline of the struggle to preserve a viable English Canadian nation. Watkins believed that the push for the construction of the Mackenzie Valley pipeline was directly related to the "American energy crisis," which threatened Canada's existence and divided English Canadians among themselves. American dependency, particularly in energy resources, brought uneven regional development and national disunity. "A major consequence of the American energy crisis is the feud between Alberta and Ontario. Only a socialist strategy committed to evening out development has the potential to reduce these tensions and permit the creation of English Canada as a viable nation." 80 In this view, the project of nation-building was based on ensuring regional unity and gaining control over resources. English Canada needed to adopt a unifying stance on the energy file if it had any hope of staving off American dominance.

\footnotetext{
79 Warnock, "The Mackenzie Valley Pipeline," 39.

${ }^{80}$ Mel Watkins, "Contradictions and Alternatives in Canada's Future," in (Canada) Ltd.: The Political Economy of Dependency, ed. Robert Laxer (Toronto: McClelland and Stewart, 1973), 263-4.
} 
In his opposition to the pipeline, Watkins repeated the widely disseminated left nationalist assertion that Canada's economy was "increasingly dominated by the United States; increasingly dominated by a handful of giant multinational corporations; and increasingly saddled with an underdeveloped industrial structure." Canada was unprepared for the new world order brought on by the energy crisis, which was defined by "inter-imperialist rivalry" for diminishing resources and condemned to a future of rapid deindustrialization and exploitation. The Mackenzie Valley Pipeline was the latest in a series of instruments of capitalist exploitation of Canada's resource hinterland. Watkins repeated his call for "socialism," not "state capitalism" in the form of the full public ownership of resources. He also called for a moratorium on further resource developments until there was adequate environmental protection, respect for the moral and legal claims of the Dene nation (an Indigenous people), and a need for the resources for use within Canada. ${ }^{81}$

In his opposition to the Mackenzie Valley Pipeline, Watkins turned his attention to helping the Dene and questioning whether the pipeline was in the national interest. The Dene were strongly opposed to the pipeline. Watkins presented the Dene's case as part of the wider problem of resource extraction and regional underdevelopment. The Dene, like Canadians as a whole, were victims of

\footnotetext{
${ }^{81}$ Mel Watkins, "Resources and Underdevelopment," in (Canada) Ltd.: The Political Economy of
} Dependency, ed. Robert Laxer (Toronto: McClelland and Stewart, 1973), 126-7. 
the "staple trap," where reliance of staples extraction and export led to dependence on foreign capital and brought underdevelopment. ${ }^{82}$

In Watkins' 1977 account of his work with the Dene, he claimed that the Canadian North was the last frontier of staples extraction. The Mackenzie Valley Pipeline demonstrated that indigenous interests were superseded by the supposed national interest. ${ }^{83}$ However, since the pipeline furthered the interests of American multinationals such as the Arctic Gas Corporation rather than the inhabitants of the Mackenzie River Valley, the national interest was in fact equated with the American interest. After all, the pipeline's primary purpose was to transport energy from one part of the United States (Alaska) to another (the Lower 48), which, in Watkins words, made it a "contemporary version of the Panama Canal." 84 The choice Canada faced was whether to protect its sovereignty and the interests of Indigenous peoples, or give in to American corporations. Watkins explained: "a significant dimension of the choice, then was choosing between the interests of non-Canadians and the interests of aboriginal peoples who are Canadians; it is of the essence of the nature of the nation-state that it should be biased in favour of its own citizenry." 85

Opposition to the Mackenzie Valley Pipeline was on the frontline of the left nationalist fight to prevent Canada's permanent integration into a continental energy market, which would have condemned the country to a fate as a perpetual

\footnotetext{
82 Watkins returned to his work on the staples trap with his 1977 article "The Staple Theory Revisited," Journal of Canadian Studies 12, no. 5 (Winter 1977), 83-94.

${ }^{83}$ Mel Watkins, "The Dene Nation: From Underdevelopment to Development (1977)," in Staples and Beyond: Selected Writings of Mel Watkins, ed. Hugh Murray Grant (Montreal: McGill-Queen's University Press, 2006), 66.

${ }^{84}$ Ibid., 68.

85 Ibid.
} 
resource hinterland. As geologist F. K. North claimed, "once the pipeline is built, any attempt by Ottawa to curtail the flow of energy south of the border would be tantamount to an act of war." According to left nationalists the proposed pipeline represented everything that was wrong with Canada's economic relationship with the United States. The pipeline would be a crucial energy lifeline to the United States, and as Sykes claimed, "the resource wealth of the Arctic, for as long as it lasts, will flow to the industrial heartland of the United States, and the concept of Canadian growth based on increasingly sophisticated manufacturing will be a faded dream." 86

The Mackenzie Valley Pipeline was never built. In 1974, growing opposition to the pipeline by Indigenous communities, in addition to concerns about its ecological effects, and issues of American ownership led the Trudeau government to launch an inquiry. In 1977 Justice Thomas Berger recommended that no pipeline be built through the Mackenzie Valley for ten years in order to settle land claims. He also found that the proposed pipeline would cause irrevocable harm to the Indigenous people, the Blackfoot, and recommended that no pipeline be constructed north of the Yukon River to avoid damaging an ecologically sensitive area. ${ }^{87}$ Ottawa accepted his findings and the pipeline was shelved. Left nationalist concerns about American dependency or energy sell-outs were not addressed, however, and the problems pertaining to the trading of energy resources remained.

\footnotetext{
${ }^{86}$ Sykes, Sellout, 25.

87 Thomas L. Berger, Northern Frontier, Northern Homeland: The Report of the Mackenzie Valley Pipeline Inquiry (Ottawa: Government of Canada, 1977), xiii-xiv.
} 
Opposition to the Mackenzie Valley Pipeline was also rooted in concern for the sustainability of Canadian energy resources. Philip Sykes believed that international relations and a country's place in the world system was tied to its wealth in, or access to, natural resources. Sykes was the former managing editor of Maclean's and a nationalist Toronto Sun editorialist. He regularly expressed concern with the export of Canada's energy resources to the United States and extensive foreign ownership of the sector. In his 1974 book, Sellout: The Giveaway of Canada's Energy Resources, Sykes argued that the late twentieth century constituted the "waning decades of the Age of Fossil Fuels," where "the accounting of the nation's economic health must be reckoned not in dollars but in natural resources." ${ }^{88}$ This statement expressed a characterization of international relations based on countries competing for access to resources with power determined by resource wealth. Canada was one of the wealthiest countries on earth if measured by resource wealth, but its potential was squandered because of the high levels of foreign ownership of the energy and mineral sector.

To further illustrate his view of Canada's place in the resource-scarce world, Sykes turned to issues pertaining to ecological destruction. He argued that Canada was open to exploitation of previously untouched regions, which (in addition to the Mackenzie Delta included the Arctic Islands, Northwest Quebec, and Northern Manitoba) would cause untold ecological destruction that will "be neither controlled, nor understood by Canadians." ${ }^{89}$ Sykes referred to Dalhousie Law

${ }^{88}$ Sykes, Sellout, 15.

${ }^{89}$ Ibid. 
Professor Ian MacDougall's assertion that Canada's "sell out" meant ecological destruction. MacDougall was a member of the "Dalhousie Four" legal scholars who in 1972 presented a brief to the Canadian Council of Resource Ministers titled Economic Development with Environmental Security. They asserted that Canada's resource wealth was threatened mostly by exploitative trade with the United States. Canada was increasingly reliant on resources for its national wealth, such as petroleum and natural gas. McDougall claimed the Canadian government was "duped" into selling more gas to the United States because regulatory bodies such as the National Energy Board "generally become captivated by the priorities of the industries they regulate." ${ }^{90}$ The energy sector was dependent on exports to the United States and regularly underestimated domestic demand and the expense of exports. This, in turn, would lead to the rapid depletion of resources and the subsequent decline of Canada's economy and the destruction of its environment. ${ }^{91}$ Sykes used the findings of the Dalhousie Four as the basis of his book.

MacDougall was concerned with ensuring Canada's ecological independence. He feared that Canada was "losing its shorelines and valleys - its tangible physical assets," adding, "if we do not establish Canadian controls over the economic and environmental rules of development there will be nothing left worth transferring [to the Americans]." 92 MacDougall held that, since the 1950s, Canadians had sold much of their non-renewable resource wealth "too cheaply," and exported energy that

\footnotetext{
${ }^{90}$ Ian McDougall et al., Economic Development with Environmental Security: A Brief Submitted to the Nova Scotia Representatives of the Canadian Council of Resources and Environment Ministers at Halifax on September 26, 1972, 14.

${ }^{91}$ McDougall et al., Economic Development with Environmental Security, 14-15.

${ }^{92}$ Sykes, Sellout, 15.
} 
could have powered new industry and employment. In this history of "selling out," Canada "paid the social and environmental costs of producing energy for Americans," and "failed to realize the economic rents of resource exploitation."93 Not only would Canada suffer rapid depletion of its resources, but Canada would also experience widespread ecological destruction. Following Sykes' reasoning, Canada's economic and environmental prospects were grim. The country was doomed to a fate as a resource hinterland, to be exploited by foreign powers hungry for energy. For Sykes, Canada's predicament was profound: "if the American corporations continue to scoop up the resources belonging to Canada and assume control of services and infrastructure provided by Canadian taxpayers, the life index of Canada as a nation surely will be conspicuously shorter than that of its natural resources." 94

\section{Left Nationalists on the Cause of the Energy Crisis}

Expressing anti-corporate sentiment, some left nationalists regarded the energy crisis and the rapid depletion of oil reserves as a plot by the energy companies to maximize profits. The greed of capitalism, represented by the oil companies, had created the energy crisis and wider problem of resource depletion. This view was best articulated by the left nationalist commentator Michel Bosquet, who in Canadian Dimension claimed that American oil companies "successfully plotted the end of oil for their own profit." Bosquet questioned if the energy crisis

\footnotetext{
${ }^{93}$ Sykes, Sellout, 15.

${ }^{94}$ Ibid., 22.
} 
really was impossible to predict, as government leaders insisted, since it was widely assumed that current oil reserves would be depleted by the end of the 1980s. The oil companies were obviously aware of the finite nature of the resources they sold, but they were "pursuing a clever plan," according to Bosquet. The strategy of the energy corporations was "to organize the end of oil." 95 In the Marxist view, the oil companies engineered the energy crisis by making Europe and North America as dependent on oil as possible. This was done to maximize profits, which would be used to ensure their smooth transition to alternative energy sources. The Arab Embargo of 1973 and subsequent energy crisis served to disrupt their timeline. Through this simplistic interpretation of the energy crisis, Bosquet implied that the sole purpose of the energy companies was to maximize profit by exploiting most of its product as rapidly as possible. Canada would suffer greatly in the process.

James Laxer agreed with Bosquet's view of the energy crisis, believing it was political and economic in nature. In his 1974 book The Energy Crisis, Laxer sought to consolidate left nationalist thinking on the energy crisis and its consequences for Canada's independence. He reiterated his Marxist view of international relations, claiming the energy crisis represented the political and economic consequences of American decline and the resulting renewal of economic rivalry between the large industrial economies. He claimed that the return of great power rivalry was the consequence of the "desperate efforts of the United States to maintain its international dominance." 96 Laxer's view of the international situation should not be

\footnotetext{
95 Michel Bosquet, "The Energy Crisis Hoax," Canadian Dimension, April 1974, 7.

${ }^{96}$ Laxer, The Energy Crisis (Toronto: Lorimer, 1974), 37.
} 
dismissed as anti-capitalist ravings, since the Nixon administration, was also preoccupied with arresting American decline and securing access to supposedly rapidly depleting energy resources. ${ }^{97}$

Laxer agreed with the assertions of other left nationalists that the American energy strategy had transformed Canada into the U. S. "energy frontier," as indicated by Washington's view that Canada's resources constituted domestic supply. Laxer feared a breakdown of the world system into warring blocs. Canada would be forced to seek "safety" as an American resource hinterland. The energy crisis represented a "acute test of the Canadian political system to act in defence of the vital interests of the Canadian people." ${ }^{98}$ Canada would have to choose between giving in to continental and global pressures and seeking false safety in American dependency or moving "towards independence." How Canada confronted the crisis and the American quest for energy self-sufficiency would "have much to do with whether the Canadian nation can itself remain viable."99 These questions were never really resolved as Canada moved into the 1980s, and the politics of energy shifted from being about Canada's place in the world and its relations with the United States to a crisis in regional politics and federalism in the era of the National Energy Program.

Conclusion: Crisis and Transformation

\footnotetext{
${ }^{97}$ Bruce Muirhead, "From Special Relationship to Third Option: Canada, the U.S., and the Nixon Shock," American Review of Canadian Studies 34, no. 3 (2004), 339

${ }^{98}$ Laxer, The Energy Crisis, 37.

${ }^{99}$ Ibid., 53.
} 
Left nationalists remained committed to disseminating their ideas into public discourse, despite the setbacks faced by their political arm in the Waffle movement. According to left nationalists, Canada was in an energy crisis that went beyond the oil shock of 1973. Only a transformation of the country into a socialist state with firm control of capital and production, in the form of public ownership of natural resources, would stave off the loss of the country's independence and its fate as a resource hinterland of a declining American empire.

New Nationalists also expressed concern with the exploitation and eventual depletion of Canada's resources. Like the left nationalists, they viewed Canada's resource wealth as crucial to the country's economic prosperity and long-term viability, even its identity. The unrestricted sale of oil, gas, and water resource wealth to the United States represented a sellout of the country's resources. Energy was at the forefront of the nationalist battle to preserve Canada's independence from the United States. The politics of energy represented by the debate over a hypothetical continental resource deal and the proposed Mackenzie Valley Pipeline united nationalists in a common cause. Both agreed that Canada's ecological independence must be maintained as a means of shielding the economy from the worst of the energy crisis and ending the dominance of the Canadian economy by the United States. In this endeavour, of primary concern to both sides was the depletion of Canada's resources. In 1973 this issue took on renewed urgency. The energy crisis applied pressure on Canada to sell more of its resources to the United States, whose policymakers viewed Canadian energy as part of domestic supply. The 
issue of needing to preserve Canada's resources from continentalization was one which both parts of the nationalist movement in English Canada rallied behind. Left nationalists differed from the New Nationalists in regarding Canada's predicament as the product of capitalist exploitation and imperialism. If Canada was to free itself from a perpetual cycle of dependency that threatened the country's very existence, it must embrace socialism to build an economy fully independent and isolated from the United States. Laxer, Watkins, and other left nationalists believed the Americans were bent on exploiting Canada's resource wealth; trade in energy was not of mutual Canadian-American benefit as its supporters claimed. To solve the problem of energy exploitation and preserve ecological independence, Canada needed to start over as a socialist economy in full control of its resources and of its destiny. To do otherwise meant the end of Canada. 


\section{Chapter 5: \\ Left Nationalists, Neo-Marxists, and the New Canadian Political Economy, 1968-1979}

This chapter outlines how left nationalism influenced the emergence of the New Canadian Political Economy (NCPE), led by a new generation of neo-Marxist Canadian political economists, social scientists, and historians concerned with Canada's position in the American dominated global economy. From the late 1960s to the mid-1970s, a neo-Marxian analysis emerged within the context of an ascendant left nationalism. Prior to this development, neo-classical economics, in synthesis with Keynesianism, ${ }^{1}$ dominated the Canadian academy. Canada's development and prosperity was based on its trading relationships, making Canada more vulnerable to the boom and bust cycle in the economics of supply and demand.

An example of Canadian neo-classicalism was the writings of economic historian Michael Bliss. In 1980, Bliss advanced the notion that Canada was "rich by nature, but poor by policy." Opposing the neo-Marxism of the NCPE, he viewed government intervention in the economy, especially for nationalist reasons, as detrimental to Canada's long-term prospects. He argued that "no matter how badly it worked, Canadians were determined to use the force of government to attempt to make themselves rich by policy." 2 Neo-Marxism offered new generations of

\footnotetext{
${ }^{1}$ Keynesianism, based on the work of British economist John Maynard Keynes, accepted the central premise of neo-classical economics that the economy is driven by supply and demand. Recessions occur because there is a lack of demand. Keynesianism called for increased government spending to make up for the decline in the private sector and return the economy to growth. In Canada, a prominent adherent of Keynesianism was the economist W. A. Mackintosh.

2 Michael Bliss, "'Rich by Nature, Poor by Policy': The State and Economic Life in Canada," in Entering the Eighties: Canada in Crisis, ed. R. Kenneth Carty and W. Peter Ward (Toronto: Oxford University Press, 1980), 78.
} 
Canadian scholars and students a new theory and practice of studying Canada's dependent relationship with the United States and advanced the notion that the state needed to take a more active role in the economic life of the country. ${ }^{3}$ In response to a failure of social democracy, this way of thinking and writing aimed to define the peculiar nature of the Canadian state, with the purpose of affecting real change in Canadian political economy.

Hugh Grant and David Wolfe recalled how new and exciting neo-Marxism was when Mel Watkins brought it into the economics department at the University of Toronto in 1973. Watkins was able to offer an alternative to the "neo-classical orthodoxy" that "extended its grip" on the university. The Economics Student Association wrote a critique of how political economy was taught and challenged neo-classicalism. They claimed that "numerous students emphasized the need for courses on the exploitation of multi-national corporations or on Marxist economic theory." This was not a surprise, because as Grant and Wolfe recalled, incoming undergraduates were familiar with the Waffle, the Committee for an Independent Canada, the Watkins and Gray Reports, and regularly read Canadian Dimension and Canadian Forum. ${ }^{4}$

In contrast to classical Marxists, neo-Marxists, many of whom were initially active in the New Left, were primarily concerned with political and social relations, rather than class and economics. Neo-Marxism was an extension of the New Left.

\footnotetext{
${ }^{3}$ Hugh Grant and David Wolfe, "Mel Watkins as Teacher, Scholar and Activist," in The Staple Theory @ 50: Reflections on the Lasting Significance of Mel Watkin's "A Staple Theory of Economic Growth," ed. James Stanford (Ottawa: Canadian Centre for Policy Alternatives, 2013), 17

${ }^{4}$ Ibid.
} 
Neo-Marxist theorists were concerned with the paradox of Marxism: its failure in the developed world, but its success in underdeveloped countries. Neo-Marxists believed that Marx had little to say about the role and structure of the state, colonialism, and culture. ${ }^{5}$ Early neo-Marxist Canadian political economists were concerned with the problem of Canadian political economy: how to define a state and economy based on a staples economy that, because of its dependence on foreign capital, was colonial in intent and result.

Many NCPE scholars were associated with the Waffle and the politics of left nationalism and turned to academic pursuits after their political project of establishing an independent socialist Canada faltered in the mid 1970s. Political scientist Gregory Albo went as far as describing the NCPE as the "intellectual offspring of the Waffle," 6 and political scientist Murray Smith described it as the product of "a historical intersection, beginning in the mid-1960s, of a single rising tide of nationalism and an international radicalization inspired in large part by antiimperialist struggles in the colonial and semi-colonial Third World."7 This chapter takes a similar position, but will also argue that the NCPE was a product of a wider transformation in the study of Canadian political economy that resulted from the arrival of dependency theory and neo-Marxism into the English Canadian academy. This transformation was led by academics active in the left nationalist movement who combined the politics of left nationalism with an analysis of Canada's political

\footnotetext{
${ }^{5}$ Aidan Foster-Carter, "Neo-Marxist Approaches to Development and Underdevelopment," Journal of Contemporary Asia 3, no. 1 (January 1973), 7.

${ }^{6}$ Gregory Albo, "Canada, Left-Nationalism and Younger Voices," Studies in Political Economy 33 (Autumn 1990), 164.

${ }^{7}$ Murray Smith, "Political Economy and the Canadian Working Class: Marxism or Nationalist Reformism," Labour/Le Travail 46 (2000), 350.
} 
economy and history. This neo-Marxist school of thought directly confronted the dominance of neo-classical political economy in the Canadian academy.

This chapter will examine the work of neo-Marxist practitioners of the New Canadian Political Economy, such as Wallace Clement, Gad Horowitz, Leo Panitch, Tom Traves, Reg Whitaker, Paul Craven, and Philip Resnick. Specific attention will be placed on examining Canadian neo-Marxist theorizations of the nature of the state and its role in capital accumulation as a framework for studying the extent to which the staples economy can account for the peculiarities of Canadian political economy. The issue of American dependence which concerned left nationalists in the late 1960s and early 1970s will also be studied. Influenced by the politics of left nationalism and intellectual trends, such as dependency theory and British New Leftist and neo-Marxist Ralph Miliband's instrumentalist writings on the state's relationship to capitalism, the New Canadian Political Economists arrived at the conclusion that Canadian political and economic independence from the United States could only be achieved by replacing capitalism with socialism.

Until the late 1960s, there was no discernable Marxist tradition in Canadian political economy. ${ }^{8}$ Canadian economists writing on Canada's trade patterns, regional economic development, and state structure were influenced by the neoclassical tradition. Neo-classicalism, in addition to studying how supply and demand were at the centre of economics, contended that Canada's political economy,

\footnotetext{
${ }^{8}$ Marxists were active in other areas of Canadian academia prior to the arrival of neo-Marxism and the NCPE. Libbie and Frank Park's Anatomy of Big Business (Toronto: Progress Books, 1962); the Marxist historian and Communist activist Stanley Ryerson's The Founding of Canada: Beginnings to 1815 (Toronto: Progress Books, 1960), and articles by H. C. Pentland are examples of Marxist historical scholarship in the Canadian setting in the 1960s.
} 
development, and prosperity, was based on trade. The main concern of Canadian neo-classical political economists had primarily been studying Canada's development from "colony to nation" and the growth of its staples extraction industries. As Waffle activist and Marxist Daniel Drache observed, neo-classicalism was embraced in Canada partly out of a desire to "clean up" Canadian economics and "make it more palpable to the American academy." Drache argued that this forced economists to stop multidisciplinary work, particularly with the field of history, and as a result, "political economy was reduced to providing metric studies of the Canadian economy ... and they abandoned any attempt to link the system of capitalism to its social milieu."9 The influence of American neo-classicalism on Canadian economics was reinforced by the new generation of Canadian economists in the 1950s and early 1960s who were educated in the United States, Mel Watkins included. ${ }^{10}$ This neo-classical hegemony in economics isolated the discipline ${ }^{11}$ and was partly the result of an absence of an alternative to neo-classical economics other than Marxism. Canadian economics and political economy needed liberation from American intellectual imperialism.

Marxism, however, did not offer a ready alternative to studying Canada's semi-peripheral political economy. The peculiar nature of Canada's political economy - the country's economy being both advanced and industrialized, but also being underdeveloped in key sectors such as manufacturing and dependent on the

\footnotetext{
9 Daniel Drache, "Rediscovering Canadian Political Economy," Journal of Canadian Studies 11, no. 3 (August 1976), 29.

${ }^{10}$ Watkins earned a graduate degree in Economics at the Massachusetts Institute of Technology.

11 The major exception in the 1940s and 1950s was the Political Economy Department at the University of Toronto, chaired by Harold Innis, which maintained an emphasis on studying Canadian economic history.
} 
United States - was not easily addressed by Marxist theory. As Drache argued, the theoretical and conceptual frameworks of $20^{\text {th }}$ century Marxism were developed to analyze "centre societies." ${ }^{12}$ Canada was not entirely a core or a peripheral society, having many of the social relations of an advanced capitalist system, but also containing many of the economic structures of a periphery, as evidenced by the high rates of foreign ownership in the resource and manufacturing sectors. ${ }^{13}$

\section{Dependency Theory in Canada}

Many New Canadian Political Economists, such as Mel Watkins, Kari Levitt, Gary Teeple and Wallace Clement, were influenced by the politics of antiimperialism, specifically the problem of American dependency. These scholars were concerned with the extent of American ownership of the Canadian economy and the power of multinational corporations, which in their view, were the agents of American imperialism. Of particular saliency was the importing and the modifying of dependency theory to address to the specific problems of Canadian political economy, characterized by a staples trap that resulted in Canada's surrender to continental corporate power.

Dependency theory emerged in the mid-1950s as a method of studying Latin America. It was first proposed by the Director of the United Nations Economic Commission for Latin America, Raúl Prebisch, who was concerned with the reasons why the rapid growth of advanced industrialized economies did not lead to growth

\footnotetext{
${ }^{12}$ Daniel Drache, "The Crisis of Canadian Political Economy: Dependency Theory Versus the New Orthodoxy," Canadian Journal of Political and Social Theory 7 (Fall 1983), 35-6.

${ }^{13}$ Ibid., 36.
} 
in underdeveloped countries, and in some cases, made the situation worse.

Dependency theory was later taken up by Latin American political economists, such as Osvaldo Sunkel and Theotônio Dos Santos to study Latin America's dependence on the United States. ${ }^{14}$ They contended that the world was divided between the core and periphery, with the former growing at the expense of the latter..$^{15}$ More radical dependency theorists, such as Andre Gunder Frank, proposed that periphery countries "de-link" themselves from the global economy as the only effective remedy for dependency, exploitation, and underdevelopment. ${ }^{16}$

Dos Santos, a key dependency theorist, did not go as far as Frank, defining dependency as part of a historical process that shaped the unequal relations between countries. ${ }^{17}$ According to Dos Santos, dependency was "an historical condition which shapes a certain structure of the world economy such that it favours some countries to the detriment of others and limits the development possibilities of the subordinate economies ... a situation in which the economy of a certain group of countries is conditioned by the development and expansion of another economy, to which their own is subjugated." Dependency theory had wide ranging implications for international relations. It could describe the world system of the age of decolonization and explain why the underdeveloped world, despite escaping colonial servitude, retained the economic and social relations of colonial

\footnotetext{
14 Vincent Ferraro, "Dependency Theory: An Introduction," in The Development Economics Reader, ed. Giorgio Secondi (London: Routledge, 2008), 58.

15 Ibid., 58-9.

16 Andres Valasco, “Dependency Theory,” Foreign Policy, November 1, 2002, 46.

17 Theotônio Dos Santos, "The Structure of Dependence," in Readings on U.S. Imperialism, ed. K. T. Fann and Donald C. C. Hodges (Boston: Porter Sargent, 1971), 226.
} 
times. For many Canadian political economists, Dos Santos' definition of dependency theory described Canada's dependent relationship with the United States.

In 1967, as Canadians were celebrating the country's Centennial, Cy Gonick outlined the problems that Canada faced, all of which, from his perspective, could be traced back to the country's dependence on the United States. Gonick believed that the Centennial was leading Canadians to accept what he called a "reluctant nationalism" and to agitate for the defence of national sovereignty. This nationalist awakening led to growing anger at an imperial relationship with the United States where Canada was "deeply penetrated by the American metropolis," a situation that made the prospect of independence "doubtful and its cost stupendous." Gonick argued that Canada's position in the American-led global capitalist economy was unique as "no other country is so bound to the U.S. as is Canada." While Western Europe was closely tied to the United States, Canada's position was more aligned with Latin America, but, unlike the Latin American countries, Canada maintained a semblance of an advanced capitalist economy. ${ }^{18}$ According to Gonick, Canada was firmly part of the "American empire," indeed its most important colony, making Canada's prosperity dependent on American prosperity.

Gonick contended that, because of its colonial relationship with the United States, it was in Canada's national interest to support American foreign policy and global economic expansion. Canada's predicament also forced it to support the United States in Vietnam. He claimed that "this is the terrible dilemma which faces

${ }^{18}$ C. W. Gonick, "The Political Economy of Canadian Independence," Canadian Dimension, May-June 1967, 13. 
Canada. We are now part of the military-industrial complex; given our close economic ties with the U.S., American imperial expansion serves our material interest." Reflecting the concern of the Canadian left with Canadian-American relations, Gonick was pessimistic about the country's prospects for independence: "should our government ever be so bold as to forcefully oppose American world policy either by diplomatic or economic means, our branch-plant economy is vulnerable to retaliatory measures." 19 This, according to Gonick, was the main consequence of American dependence.

To grapple with consequences outlined by Gonick, neo-Marxist scholars had first to understand the causes. The Canadian political economy intellectual tradition was largely unprepared for this task. Gonick was frustrated with the shortfalls of Innis's Staples Thesis as the only alternative to the hegemony of neo-classicalism. As he put it, the Staples Thesis was actually "a pseudonym for a kind of imperial relationship," 20 and was inadequate for the task of challenging American dependency. Watkins disagreed, claiming that Innis was actually an anti-imperialist. As Watkins recalled, Innis "was looking at all the great empires and why they fell. Innis was very much a liberal, profoundly suspicious of great aggregations of power. And we has very opposed, as an intellectual, to American imperialism. Now antiimperialism is on the agenda, but Innis was years ahead of his time in this country." ${ }^{21}$ What was needed to address Gonick's complaint was a new theory of

\footnotetext{
${ }^{19}$ Gonick, "The Political Economy of Canadian Independence," 13.

20 Ibid., 12.

${ }^{21}$ Watkins, "Getting to Democratic Socialism 1: Points of Departure," in Gordon to Watkins to You: A Documentary: The Battle for the Control of our Economy, ed. Dave Godfrey and Mel Watkins (Toronto: New Press, 1970), 3.
} 
economic growth and dependency, whether developed by Canadians, or in keeping with intellectual traditions, imported from abroad and modified.

Mel Watkins, prior to his work on the Watkins Report and his embrace of left nationalism, was an early practitioner of dependency theory, which he used to expand the Staples Thesis first advanced by Harold Innis. Watkins studied under Innis at University of Toronto and wanted to expand Innis' study of the economic history of Canada to discern how Canada became semi-peripheral through industrial development based on staples extraction. ${ }^{22}$ In his 1963 article "A Staple Theory of Economic Growth," Watkins contended that a "staple approach" to studying Canadian economic history was mostly a Canadian innovation and perhaps Canada's "most distinctive innovation" to political economy. Out of the "staple theory" emerged Watkins' notion of a "staples trap." ${ }^{3}$ Watkins' "staples theory of growth" argued that, in a frontier economy abundant with natural resources but with a scarcity of labour, the entire economy was characterized by the core economy seeking ways to incorporate the periphery. Canada's hinterland economy was dependent on the international demand for the staple, the development and availability of the technology needed for extraction, the "mobility of productive

\footnotetext{
22 Duncan Cameron, “Watkins, Innis, and Canadian Economics," in The Staple Theory @ 50: Reflections on the Lasting Significance of Mel Watkins': "A Staple Theory of Economic Growth," ed. James Stanford (Ottawa: Canadian Centre for Policy Alternatives, 2013), 25-6.

${ }^{23}$ For a brief discussion and analysis of Watkins' "Staple Theory of Economic Growth" and the staples trap see, Abraham Rotstein, "The Staple Theory Redux: On the Origin of Species," in The Staple Theory @ 50: Reflections on the Lasting Significance of Mel Watkins' "A Staple Theory of Economic Growth," ed. James Stanford (Ottawa: Canadian Centre for Policy Alternatives, 2013), 11-15 For a critical analysis, see Paul Kellogg, Escape from the Staples Trap: Political Economy after Left Nationalism (Toronto: University of Toronto Press, 2015).
} 
factors," and the character and availability of the staple resource. ${ }^{24}$ Watkins' worry about a staples trap was situated in a historical context of rising left nationalism. Movements such as the Waffle, the broader debates occurring within Marxist thought, and the efforts by political economists to mediate them, created an opportune moment for the dissemination of his ideas.

This staples trap, as identified by Watkins, led to Canada's "silent surrender." In her popular study of Canada's dependent economic relationship with the United States, Kari Levitt argued that Canada was the victim of American neo-colonialism. Her book, Silent Surrender: The Multinational Corporation in Canada, stipulated that Canada's reduction to the status of an American colony was the result of the Canadian state's dependence on exporting staples and American foreign investment in the form of branch plants and multinational corporations. ${ }^{25}$ An economist at McGill University, Levitt was an early supporter of the English Canadian left nationalist movement, having been introduced to the writings of dependency theorists active in Montreal during the 1960s such as Andre Gunder Frank. ${ }^{26} \mathrm{Her}$ embrace of dependency theory and her views on the detriments of foreign direct investment through multinational corporations reflected the left nationalist affinity to the politics and theories of anti-imperialism.

Watkins, who was an early supporter of Levitt's and wrote the introduction

\footnotetext{
${ }^{24}$ Watkins, "A Staple Theory of Economic Growth," Canadian Journal of Economics and Political Science 29, no. 2 (May 1963), 152.

${ }^{25}$ Kari Levitt, Silent Surrender: The Multinational Corporation in Canada (Toronto: Macmillan of Canada, 1970), 24-5.

${ }^{26}$ See, Sean Mills, The Empire Within: Postcolonial Thought and Political Activism in Sixties Montreal (Montreal: McGill-Queen's University Press, 2010) for more on the dependency theorists active in Montreal during the 1960s.
} 
to the first edition of Silent Surrender in 1970, believed that the book helped popularize the left nationalist movement and offered a link between the dependency theorists active in Canada and the developing world. In his 2002 review of the legacy of Silent Surrender, Watkins claimed that Levitt's analysis, and the political economy school it helped found, proved that Canada was the world's "richest dependent developed industrialized country" and "the most neo-colonial country in the world." ${ }^{27}$ Levitt agreed with Watkins' assessment, telling Sean Mills in a 2007 interview that Canadian left nationalism was part of a global anti-imperialist movement that linked societies that wanted to "control their own future." Canadian left nationalists and their counterparts in the Caribbean, an area where Levitt had concentrated most of her academic work, "wanted to cut links of dependency with traditional metropoles. Canada and the Caribbean are on opposite ends of a spectrum of dependency. The situations were very different, of course, but these societies all wanted to become subjects rather than objects of history." ${ }^{28}$ After the publication of Silent Surrender, Levitt returned to studying dependency in the Caribbean. As a result, she was not an active member of the NCPE. Nevertheless, Levitt's anti-imperialist thought, and dependency theory approach, found its way into the New Canadian Political Economy.

\footnotetext{
${ }^{27}$ Mel Watkins, quoted in Paul Kellogg, "Kari Levitt and the Long Detour of Canadian Political Economy," Studies in Canadian Political Economy 76 (Autumn 2005), 31.

${ }^{28}$ Sean Mills, "Without Surrender: An interview with Kari Levitt," Race and Class 56, no. 1 (October 2007), 56.
} 
Capitalism, Nationalism, and Continental Corporate Power

One of the first major neo-Marxist academic studies of the Canadian state's relationship with capitalism appeared in 1971 as a collection of essays by mostly young scholars organized under the title Capitalism and the National Question in Canada, edited by the left nationalist academic Gary Teeple. Teeple's Marxist academic pursuits were influenced by his left nationalist political beliefs. The purpose of the volume, Teeple wrote, was to break from traditional neo-classical orthodoxy and introduce Marxist and neo-Marxist analyses into the study of the origins and developments of Canadian capitalism and political economy. Classical Marxist studies such as class analysis appeared in essays such as Leo Johnson's “The Development of Class in Canada in the Twentieth Century." Johnson made the novel argument, by Canadian standards, that Canada did indeed have a class system made up of workers and the bourgeoise. This was important for a Marxist like Johnson since Canada was "approaching the classical Marxist model of capitalism," due to the decline of the bourgeoisie, the maturation of capitalism, and the impoverishment of low-income earners due to chronically high unemployment. ${ }^{29}$

Capitalism and the National Question was met with positive reviews. For example, C.B. Macpherson, the notable Canadian political scientist, wrote that it was largely successful in its endeavour to introduce Marxism into the study of Canadian political economy. He acknowledged there was a lack of Marxist scholarship in Canada, with established academics "innocent or scornful of Marxism." Macpherson

\footnotetext{
${ }^{29}$ Leo Johnson, "The Development of Class in Canada in the Twentieth Century," in Capitalism and the
} National Question in Canada, ed. Gary Teeple (Toronto: University of Toronto Press, 1972), 178. 
believed that the appearance of the volume meant that Canadian academics could finally ask if the "insights of classical Marxism, applied directly to Canada, give us a deeper understanding of our own society and more effective guidance towards transforming it?" 30 While Capitalism and the National Question was extensive, it was by no means comprehensive, but Macpherson believed its publication represented a "new beginning" in the study of Canadian political economy.

In introducing Capitalism and the National Question, Teeple outlined the origins and consequences of the Canadian economy's domination by foreign capital. In doing so he defined the problems the New Canadian Political Economy hoped to address. Teeple stated, "although little control of industry lies in the hands of Canadian capitalists, it is still held that Canada is a politically independent state. The appearance of autonomy, however, is illusionary as the political system of a modern nation-state can scarcely operate independently of its economy." 31 Reflecting on the general neo-Marxist view of state-capital relations, Teeple wrote that "the role of a government in a capitalist country is to regulate social relations in the interests of capital accumulation. If a nation's capitalists predominate in the ownership of the means of production, the government will legislate policies to promote their interests [which become] the national interest." 32 Canada found itself in a position where its capitalist class was beholden to the interests of the American branch plant owners. In this situation, the Canadian national interest became what was best for

\footnotetext{
${ }^{30}$ C. B. Macpherson, "Marxism in Canada: A New Beginning," Canadian Dimension 9, SeptemberOctober 1972, 67.

${ }^{31}$ Gary Teeple, "Introduction," in his Capitalism and the National Question in Canada (Toronto: University of Toronto Press, 1972), xi.

32 Ibid.
} 
American investors and industrial owners. What made it more critical in Canada was that many of the individuals and corporations were in foreign (American) hands. Socialism, which promised to free the state from the control of capital, also promised to free Canada from its colonial overlords south of the border.

How did Canada lose its independence? According to Teeple, a historical analysis of the development of Canadian capitalism demonstrated that capital accumulation and the means of production were always dependent on foreigners. Historically, commercial capital was the dominant form of Canadian wealth, with most profits being made by supplying resources to international markets, first to Britain, and then to the United States. Teeple also demonstrated the neo-Marxist preoccupation with class mentality. "This dependency on foreign industry prevented the dominant groups of Canadian capitalists from having a strong consciousness of themselves as the rulers of a nation-state." 33 Teeple contended that Canada's ruling class (owners of capital) have, through historical patterns and contemporary trends, developed a colonial mindset and were relegated to ownership of the finance and transportation sectors. Unlike their counterparts in other advanced industrial nations, Canadian owners of capital were unable or unwilling to develop a Canadian economy independent of foreign influence because they were trapped in a colonial mentality.

The essays in Capitalism and the National Question in Canada outlined the left nationalist political agenda that combined anti-imperialism with socialism. All the contributors argued that Canada was deeply embedded in the American empire and

\footnotetext{
33 Teeple, “Introduction," xi.
} 
a political agenda was needed to address the situation. As a left nationalist, Teeple viewed anti-imperialism and a socialist agenda as inseparable. He argued that an industrial ruling class, which Canada lacked, "often seeks to rationalize its role as a colonial exploiter with a moral declaration of superiority." Expressing contemporary concerns about American foreign policy and Canada's complicity in the American "imperial project," Teeple argued that the "domination of the United States over the so-called free world is the present basis of the American belief that its 'way of life' is the best and all other nations are envious of it ... [and] American values are thrust upon those nations, like Canada, unfortunate enough to be tied to the American empire."34

In 1971, thought Teeple, Canada's predicament was apparent. The United States had invested more in Canada than in any other country, and, since 1950, more than in all of Latin America combined. Canada was thus the most important colony of the United States. Teeple acknowledged the development of New Nationalism in Canada, but he was not hopeful that it would succeed in freeing Canada from colonial subservience. Reflecting the views of the wider left nationalist moment, Teeple dismissed the New Nationalism as a mostly middle-class movement that was concerned with maintaining its position in the cultural life of Canada. As long as the capitalist political order was accepted, there "will be successful accommodation for those social strata [the middle class] whose interests are not in fundamental opposition to U.S. hegemony." 35 A political program that credibly

\footnotetext{
34 Teeple, "Introduction," xii.
}

35 Ibid., xiv. 
addressed American dependence was one that confronted American hegemony at home and abroad.

With regards to Canada's political parties, Teeple reiterated the left nationalist refrain of remaking Canadian left-wing politics. He had little confidence in the New Democratic Party (NDP) in its present form, arguing that its program would not bring about fundamental change because of its "acceptance of Liberal Democracy and modern capitalism," and the strong influence of American-led union in the direction of the party. "The major liberal democratic parties in Canada... represent interests which are largely American." Teeple was open to the creation of a new political party. He believed that as long as the political situation was maintained, "socialists cannot ignore the question of the formation of a new political party." 36

Political economist and historian R. T. Naylor shared Teeple's views on left nationalism and sought to determine the historical reasons for the entrenchment of capitalism in Canada. In his essay, "The Rise and Fall of the Third Commercial Empire of the St. Lawrence," Naylor provided a substantial historical overview of the development of the Canadian political economy and the historical roots of Canada's colonial dependence. ${ }^{37} \mathrm{He}$ wanted to reinvigorate the study of Canadian economic history by introducing class analysis. Naylor contended that the two general theories of Canadian political economy, the staples and Laurentian theses, had not adequately considered the "the Canadian capitalist class," and that Marxist studies

\footnotetext{
36 Teeple, "Introduction," xv.

${ }^{37}$ R. T. Naylor, "The Rise and Fall of the Third Commercial Empire of the St. Lawrence," in Capitalism and the National Question, ed. Gary Teeple (Toronto: University of Toronto Press, 1972).
} 
have misinterpreted its characteristics. ${ }^{38}$ In discussing the consequences of American branch plant capitalism, Naylor argued that parent corporations preferred complete ownership of their "offspring," which led to underdevelopment in the hinterland and a restriction of outflows of Canadian investment capital with the result being an endless cycle of dependence. The Canadian "industrial bourgeoisie was relegated to managing branch-pants for foreign masters and served as junior partners in continental capitalism." ${ }^{39}$ Canada's legacy of merchant capitalism and industrial dependence on colonial powers had forced it into a cycle of dependency and complacency. For Naylor and his fellow neo-Marxists, this was the essence of the Canadian national question and the necessary basis of any study of the role and nature of the state in capitalist development.

Wallace Clement's Continental Corporate Power (1977) reflected the NCPE's concern with capitalism and the national question. Clement was concerned with studying developments in the American economic structure and how they affected Canada. He portrayed his study as being essential to understanding relations between Canada and the United States and as part of the growing canon of neoMarxist scholarship on international capitalism and its implications for nationstates. Continental Corporate Power was Clement's way of addressing the shortage of works on Canadian political economy. He claimed that significant work had been done in studying the relations between the United States (the core) and the "Third World" (the periphery), but little had been written on American relations with "go

\footnotetext{
${ }^{38}$ Naylor, "The Rise and Fall of the Third Commercial Empire of the St. Lawrence," 31.

${ }^{39}$ Ibid., 31-2.
} 
between nations like Canada." 40 Canada was a critical case study in understanding a world economic order defined by core and periphery nations because Canada's relationship with the United States was a clear example of how external centres of power influence a country's internal developments. Specifically, in Canada's case, the country had undergone a policy of "defensive expansionism," the clearest example of which was Canada's rapid expansion westward in the late 19th and early 20th centuries in order to protect its boundaries from American encroachment. Clement argued that an alliance formed between the "leading elements" of Canadian and American capital, which "mutually reinforce the power and advantages of each." ${ }^{41}$ Canada was trapped in a cycle of American dependency. Concentrating attention on corporations, Clement identified the problem of Canadian political economy, which he described as the "Canadian quandary." 42 Clement's thesis was that Canada's "confinement" by the expansionism of the "American empire" had great ramifications for the patterns of corporate ownership within the Canadian economy, for the relationships between corporations, and for the nature of the economic elites of both countries. ${ }^{43}$ The alliance between Canadian and American corporate interests was unequal, and, as a result, Canada's economy was shaped to "conform to the dominance of the United States." The "Canadian quandary" referred to Canada's traits of both advanced independent capitalist

\footnotetext{
${ }^{40}$ Wallace Clement, Continental Corporate Power: Economic Linkages Between Canada and the United States (Toronto: McClelland and Stewart, 1977), 1.

41 Ibid.

${ }^{42}$ A reference to economist Harry Johnson's critical characterization of the problem of American dominance of the economy outlined by economic nationalists in the late 1950s and early 1960s. Harry Johnson, The Canadian Quandary: Economic Problems and Policies (Toronto: McGraw Hill, 1963).

${ }^{43}$ Clement, Continental Corporate Power, 6.
} 
economies and the peripheral nations of the Third World. The country enjoyed the trappings of advanced capitalism, but it was not independent; Canadian prosperity and corporate power were dependent on the United States. This problem emerged when multinationals "do not promote an equal sharing among or within nations of the resources they control; instead, they ensure that inequality within and between nations will be maintained and even expanded." 44 As a result of this prevalence of the multinational corporations and Canada's earlier history of being a colony, Canada was both underdeveloped and overdeveloped.

Clement situated his work as part of a recovery of Canada as a subject of analysis in political economy. In 1978, along with Daniel Drache, Clement characterized this revival as the result of a renewed interest in radical scholarship with its roots in a broadly defined Marxist tradition." Clement and Drache correctly observed that this neo-Marxist revival marked a reinvigoration of the Canadian social sciences that resulted from an awareness of contemporary issues such as the national question and a "desire to do something about the Canadian condition." 45 Clement's work was part of this project and imported theories to the Canadian situation to critical examine the Canadian quandary. One of these theories was dependency theory.

Clement used dependency models developed primarily for studying Latin America's relations with advanced capitalist economies. ${ }^{46} \mathrm{He}$ argued that Canada

\footnotetext{
${ }^{44}$ Clement, Continental Corporate Power, 289-90.

${ }^{45}$ Wallace Clement and Daniel Drache, A Practical Guide to Canadian Political Economy (Toronto: J. Lorimer, 1978), iii.

${ }^{46}$ According to Clement, dependency theory "analyzes class structures according to their relations with foreign centres." Its central feature was "the unequal relationship between interdependent classes, which formed asymmetrical associations within nations or between classes, which form
} 
was a secondary power and had a distorted economic system because its colonial origins. Industrialization occurred in the shadow of the industrial might of the United States - what Clement called "shirt-tail development." Instead of employing the techniques of autonomous development, Canadian capitalists and members of the elite had adapted Canada's economy as part of a much broader economic system, the capitalist world order and the continental economic system of North America. ${ }^{47}$

Clement also considered the state's role in perpetuating the continental system of corporate power and Canadian dependence on the American direct investment through branch-plants. He agreed with the neo-Marxist interpretation of the state's role in capitalism, arguing "the system has emerged not in spite of politicians, but because they have permitted it." State power was real and must be considered when examining corporate power structures and the asymmetrical relations between Canada and the United States. Clement acknowledged that there was a dichotomy between private versus state power, but, ultimately, the state had the upper hand, since the state possessed the power to make decisions about private property. Private property was an institution granted by the state, which made it "territorially bounded and sanctioned." Clement was adamant that the state could rein in corporate power. ${ }^{48} \mathrm{He}$ believed that liberal democracies, such as Canada, risked giving too much power to private interests such as corporations, at

\footnotetext{
asymmetrical associations either within nations or between nations." Clement, Continental Corporate Power, 21-22.

${ }^{47}$ Clement and Drache, A Practical Guide to Canadian Political Economy, 7-8.

${ }^{48}$ Clement, Continental Corporate Power, 300.
} 
the expense of state sovereignty. With corporate power in Canada highly concentrated in the hands of multinationals based in the United States, the concern was over the extent to which the Canadian state surrendered its sovereignty to the United States.

Ray Schmidt, in his 1981 critical retrospective of Canadian political economy, argued that dependency theory was used primarily by the NCPE as a critique of the neo-classicalism espoused by Harold Innis and Donald Creighton. ${ }^{49}$ Schmidt held that the notion articulated by Innis that Canadians were mostly "hewers of wood and drawers of water" was seen by the proponents of dependency theory as "an implicit statement of denigration of the Canadian position in a world division of labour." Schmidt held that it was crucial to situate Canadian neo-Marxism within a historical and social context characterized by left-nationalist movements such as the Waffle, the broader debates occurring within Marxist thought and the efforts by political economists to mediate them. ${ }^{50}$ Schmidt's contention was accurate. The introduction of neo-Marxism into Canada served to reinforce Innis's assertion that the Canadian political economy was unique. But, this uniqueness was a problem, since the Canadian staples economy forced Canada to remain a colonial dependency.

Neo-Marxism for a Left Nationalist Agenda

In addition to their concern with the dependent characteristics of the Canadian economy, many neo-Marxist political economists in the 1960s and 1970s

\footnotetext{
${ }^{49}$ Ray Schmidt, “Canadian Political Economy: A Critique," Studies in Political Economy 6 (1981), 71.
} ${ }^{50}$ Ibid. 
moved beyond the debates over the nature of the Canadian economy and studied the role that the Canadian state played in the preservation of American dependency. These New Canadian Political Economists included Gad Horowitz, Leo Panitch, Daniel Drache, Reg Whitaker, and Tom Traves. They were not concerned specifically with dependency theory, but with advancing the theories on state formation presented by the neo-Marxist British political scientist Ralph Miliband. The main priority of these scholars associated with the NCPE was the introduction of a neoMarxist tradition into the Canadian academy. This was less about the politics of antiimperialism; it was more about the other dimension of the left nationalism movement: the desire to advance socialist politics in Canada.

Neo-Marxist scholars became concerned with the nature and role of the Canadian state as a result of contemporary concerns over the failure of social democracy in an economy that was dominated by foreign capital interests. They placed intense scrutiny on the Canadian state's relationship to capital and its consequences for class formation and conflict. Historiographical emphasis was placed on the nineteenth century, for it was here that historians could find a state that was in formation, the nature of which had consequences for Canadian class, cultural, and national identity. Despite the diversity in their influences and concerns, Canadian neo-Marxists were all interested in investigating how the Canadian state fulfilled its legitimation function in a colonial and capitalist context.

In Britain, neo-Marxism emerged as part of the wider agenda of the political New Left and proved instrumental in influencing a new generation of Canadian political economists grappling with the problem of Canadian political economy. In 
works such as The State in Capitalist Society (1969) and later in Marxism and Politics (1977), Ralph Miliband addressed Marx's limited theorizations state formation, governance and political structures. Miliband was a stalwart of the British New left and one of the main neo-Marxist scholars. He had a radical political outlook, hoping to transform Britain into a fully socialist political economy. In 1967 Miliband, along with other British New Leftists such as Terry Eagleton, Stuart Hall, and E. P.

Thompson, wrote the May Day Manifesto, which proposed a radical realignment of British politics along socialist lines. The Manifesto used similar language to that of Canadian left nationalists, with their critiques of the American-led economic order and imperialism and the power of the multinational corporations. ${ }^{51}$ Watkins cited the May Day Manifesto as influential to his politics, writing in Gordon to Watkins to You (1970) that it helped him define what it meant to be a democratic socialist. "If you want a more specific definition [of socialism] I'll cheat and read an excerpt of the May Day Manifesto," he wrote, before going on to quote it at length. ${ }^{52}$ Miliband and other British neo-Marxists, kindred spirits to the socialist politics of English Canadian left nationalism, sought to study the state in order to transform it, a task that was readily taken up by their Canadian counterparts in the NCPE.

Miliband took an instrumentalist stance on the role of the state in legitimizing capitalism. ${ }^{53}$ He contended that state served the interests of capitalism

\footnotetext{
51 Raymond Williams, "Preface," in The May Day Manifesto 1968, ed. Raymond Williams (London: Verso Books, 2018. Reprint), xiii-xiv.

52 Watkins implied that the May Day Manifesto's definition of socialism helped inform the politics of imperialism of the left nationalists. Mel Watkins, "Getting to Democratic Socialism 4: Here and Now," in Gordon to Watkins to You: A Documentary: The Battle for Control of Our Economy, ed. Dave Godfrey and Mel Watkins (Toronto: New Press, 1970), 136-37.

53 In contrast to "structuralism" which held that that state was a "bourgeoisie entity" that was not influenced by individuals and thus could not be changed by a new class coming to power. Miliband
} 
and its primary purpose was the preservation of the capitalist system.

Instrumentalist Marxism held that government leaders shared common class backgrounds and that their decisions reflected their class interests. The state and legal structures were primarily an instrument for members of the dominant class to use for their own interests, maintaining power through legitimizing their hegemonic position. Writing in 1969 in The State in Capitalist Society, Miliband claimed that "it has remained a basic fact of life in advanced capitalist countries that the vast majority of men and women in these countries has been governed, represented, administered, judged, and commanded in war by people drawn from other, economically superior and relatively distant classes." 54 In Canada's case, as the Canadian neo-Marxists argued, the class in power was controlled by American capital and thus had a colonial mentality. As a result, state was in the thrall of American corporate and political power.

The task of the Marxist theorist of the state, according to the historical sociologist Philip Abrams, was investigating "the actual forms and modes of dependence or independence that relate it to the socio-economic." ${ }^{55}$ Abrams intervened to challenge the prevailing orthodoxy and instead called for Marxists to concentrate on Marx's insistence that the state is "overwhelmingly ideological." In this sense, the state was better understood as a tool for legitimizing the process of

famously debated his instrumentalist state theory with the structuralist Nicos Poulantzas in the pages of the New Left Review throughout the late 1960s and 1970s. Most Marxist academics studying the state followed the instrumentalist or structuralist method.

${ }^{54}$ Ralph Miliband, The State in Capitalist Society (London: Quartet Books, 1973. Reprint), 68-9.

55 Philip Abrams, "Notes on the Difficulty of Studying the State," Journal of Historical Sociology 1, no. 1 (1988), 59. 
subjugation. ${ }^{56}$ According to Abrams, Marxist writings on the state had not comprehended this, despite many attempts by "neo-Marxists" to study the state in more detail. Ralph Miliband was the first scholar to break down the separation between the state and civil society. He argued that the state was a collection of institutions such as the bureaucracy, police, judiciary, and parliamentary assemblies, all of which had stakes in society through the influence of political organizations, religion, and other social institutions. ${ }^{57}$ These debates and theories were discussed in seminars and study groups on university campuses throughout Canada, and contributed to the rise in interest in neo-Marxism amongst a new generation of students and scholars of political economy. ${ }^{58}$

In 1968 political scientist Gad Horowitz had produced a major historical study of the role and nature of the Canadian state. His writings were highly influential in the early years of the Canadian left nationalist movement. Like his contemporaries, Horowitz was concerned with investigating the origins of a Canadian state system that seemed hostile to social democracy. Appearing in his study on the Canadian labour movement, Canadian Labour in Politics, his essay "Conservatism, Liberalism, and Socialism in Canada: An Interpretation," asked what accounted for the "striking differences in the fortunes of socialism in two very similar societies [Canada and the United States]." ${ }^{\prime 9}$ Horowitz turned to neo-Marxism to explain the relative strength of socialism in Canada as opposed to the United

\footnotetext{
${ }^{56}$ Abrams, "Notes on the Difficulty of Studying the State," 69.

57 Ibid., 71.

58 Chris Hurl and Benjamin Christensen, "Building the New Canadian Political Economy," Studies in Canadian Political Economy 96, no. 1 (2015), 183.

${ }^{59}$ Gad Horowitz, Canadian Labour in Politics (Toronto: University of Toronto Press, 1968), 3.
} 
States. Horowitz, following Innis, argued that Canada was unique, and the relative strength of socialism in Canada was "related to the relative strength of Toryism, and the different position and character of liberalism in the two countries." 60

In an attempt to define the ideology of the Canadian state, Horowitz argued that English Canada could be viewed as an offshoot of American liberalism but adapted to a sparsely populated northern climate with a staples-based economy. In addition to this, there was a "Tory Touch" that originated from the American Revolution. The Tory influence, according to Horowitz, reached a point of "congealment" after the arrival of the Loyalists. Canadian socialism was rooted in a Protestant, Fabian (reformist) tradition, rather than the Marxist character of the American. Horowitz turned to the contemporary phenomenon of the Red Tory (embodied by George Grant) as an example of the peculiar nature of socialism and conservatism in Canada. The Red Tory, stipulated Horowitz, combined elements of Toryism and socialism into an ideology that transcends the Progressive Conservative and New Democratic parties, laments the death of true British conservatism in Canada, attacks Liberals as individualists, and defines socialism as a variant of conservatism. ${ }^{61}$ Canadian socialism in the 1960 s was, therefore, a unique product of peculiar historical and economic circumstances.

Horowitz faced criticism from neo-Marxists such as Naylor, who argued that the presence of Toryism in Canada was "nothing but a phenomenon of the material interests of our ruling class." For Naylor, Toryism in Canada was not the result of a

${ }^{60}$ Horowitz, Canadian Labour in Politics, 3.

${ }^{61}$ Ibid., 23. 
transfusion of the British variety into the political culture; the Tory touch was the result of the underdevelopment of Canada as an industrial capitalist political economy. Canada's unique Tory tradition was the result of the staples economy. The Canadian bourgeoisie was tied to the staples economy. A "mercantile element" dominated, and the mercantile capitalists were always less liberal than their industrial counterparts because the mercantilists must work with the state structure to enforce their monopoly. The willingness of the Canadian economic elite to use the state, as opposed to their British and American counterparts, to control and develop the economy was "not the consequence of Toryism, but its cause." Horowitz disagreed with the classical Marxist account of this ideology and its relation to the staples economy because it did not sufficiently "interrogate" the structure of the state. ${ }^{62}$ Here he demonstrated the influence of the emergent neoMarxist view of political economy, which was being advanced by Miliband.

Horowitz later claimed that his writings on Canadian political ideologies were not an attempt to subvert economic explanations of the state's role; instead, they demonstrated how ideologies made use of the Canadian state. Horowitz addressed the contemporary concern amongst the Canadian left about the plight of social democracy. He argued that, to understand the failure to bring about fundamental change to the capitalist system, political economists must move away from studying simply economic means of production and class structure and instead concentrate on a neo-Marxist study of the nature and role of the state.

${ }^{62}$ Gad Horowitz, "Notes on 'Conservatism, Liberalism, and Socialism in Canada," Canadian Journal of Political Science 2 (June 1978), 384. 
A central concern of the NCPE was the Canadian state's role in the development of capitalism. Here they were influenced by Miliband's The State in Capitalist Society, which emerged a foundational text in the neo-Marxist framework of studying the state. ${ }^{63}$ The NCPE understood Canada as a prime example of the "state capitalism" described by Miliband. In this endeavour, it is necessary to recall the distinction between the state, the government, and the political system, as outlined by Miliband. They framed their studies by questioning if the state was the tool of the capitalist class. How are competing corporate interests reconciled with broader class interests? How does the state promote social cohesion between competitive classes? How are these functions reflected in the structure of the state itself? These neo-Marxian questions were central to writers of the New Canadian Political Economy and to those hoping to reform, or overthrow, the capitalist state system. They contended that the Canadian state had historically played a direct role in the development of the market economy, especially when contrasted to the United States. A consensus emerged in the NCPE which held that the Canadian economy developed under the state's protection because of Canada's vast geography, sparse population, and lack of local financial capital.

A prominent NCPE follower of Miliband was the political economist Leo Panitch. Miliband was Panitch's PhD thesis supervisor at the London School of Economics, and they continued to work together into the 1990s, serving as coeditors of Socialist Register. ${ }^{64}$ Panitch was inspired by his experience in the United

\footnotetext{
${ }^{63}$ Leo Panitch, "The Role and Nature of the Canadian State," in The Canadian State: Political Economy and Political Power, ed. Leo Panitch (Toronto: University of Toronto Press), 6.

${ }^{64}$ Michael Newman, Ralph Miliband and the Politics of the New Left (London: The Merlin Press), 286.
} 
Kingdom studying under Miliband and resolved to introduce Miliband to a wider Canadian audience. While the Toronto academic scene was mostly interested in anti-imperialism, Panitch wanted to concentrate his efforts on studying the state as a means of determining the reasons for the lack of a socialist and Marxist tradition in Canada as a means of advancing socialist politics. ${ }^{65}$ In this task, Panitch found a ready audience at Carleton University in Ottawa.

At Carleton, Panitch helped found what was referred to by its participants as the "Carleton School of Political Economy," which aimed to turn the attention of the NCPE away from the debates and theories on anti-imperialism and dependency. Panitch and the Carleton School believed that anti-imperialism was consuming too much attention, and they blamed it for the failure of the Waffle. Instead, they wanted the NCPE to focus on neo-Marxism and advance a socialist theory of the state. Their central concern was not the cause and consequence of Canadian underdevelopment as a semi-periphery economy; rather, it was studying the reasons for the lack of socialism in Canada. In this sense the Waffle had failed because it was not socialist enough; neither of course was the New Democratic Party. As Panitch said in a 2013 interview, "the most important thing we were doing was not so much being antiimperialists, which drove the intellectuals around the Waffle." Panitch explained he did not want to abandon the left nationalist cause and explained that his intentions "were rejuvenating, renewing, creating anew, a set of intellectual concepts that would better allow the prosecution of class struggle, " meaning that he opposed bringing about a new theory of socialism that was adapted to the Canadian

${ }^{65}$ Hurl and Christensen, "Building the New Canadian Political Economy," 183. 
context. ${ }^{66}$ This intellectual divide between those who wanted to advance antiimperialism over socialism did not mean there was division within the left nationalist movement. Both sides sought the same goal: an independent and socialist Canada. The disagreement was over which part should be emphasized.

Panitch enjoyed success in his academic endeavour of reinvigorating socialism by introducing Miliband to a Canadian context. In what could be discerned as a show of unity in the NCPE between the anti-imperialist and socialist camps, Panitch and Watkins co-edited a series of monographs and edited collections published in the late 1970s and early 1980s under the banner of "The State in Economic Life." Writing in the preface of his 1977 edited collection The Canadian State: Political Economy and Political Power, Panitch emphasized the revival of interest in studying the state from a neo-Marxist perspective. This volume was the first in the series and served to introduce the writings of other scholars of the NCPE. These monographs, some of which were written by prominent left nationalists such as Tom Traves, Paul Craven and others, espoused an instrumentalist view of the Canadian state and aimed to apply Miliband's theories of capitalism and state to Canada. In the Canadian State, Panitch maintained his affinity for Miliband's insights on the subject. ${ }^{67}$ Panitch believed that Canadian political economy would benefit

\footnotetext{
${ }^{66}$ Hurl and Christensen, "Building the New Canadian Political Economy," 184.

${ }^{67}$ Upon Miliband's passing in 1994, Panitch reflected on Miliband's influence in his work. He wrote, "It was only with The State in Capitalist Society that a student reared in British and North American political science had the sense that one finally could go beyond just criticizing the dominant paradigm and move to an alternative theorization. Miliband left us in no doubt that this theorization had to be a Marxist one; but he also demonstrated that it could be the kind of independent Marxism that did not cut itself off from the non-Marxist intellectual world, indeed that it would be best if one actively tried to incorporate the best insights of other approaches into the Marxist theorization." Leo Panitch, “Ralph Miliband, Socialist Intellectual: 1924-1994," Socialist Register (1995), 13.
} 
from Miliband's insights on the roles, divisions, and influences of the state. The Canadian State represented Panitch's major effort at importing Miliband's writings on capitalism and the state into the Canadian academy. Panitch claimed that the neo-Marxist interest in studying the state was partly the result of the failure of social democracy to make fundamental changes to the social order, a concern shared by Miliband and Horowitz.

Panitch described a problem in Canadian political economy defined by a need for a theory that could "systematically address Canada's unevenly developed terms with a state that presides over a society that is increasingly dominated by American capital." 68 This was an acknowledgment by Panitch that his desire to advance the socialist cause relied on a theory of addressing Canada's dependence on the United States. He argued that the renewed interest in a neo-Marxist theory of the state was a reflection of contemporary political science being incapable of adequately explaining the political questions of the late 1970s, such as the failings of global leftist politics and Canadian left nationalism. Nevertheless, true to the views of the Carleton School of the NCPE, Panitch claimed that the fundamental problem of Canadian political economy was the absence in Canada of "a strong indigenous Marxist tradition in politics or intellectual life." However, Panitch asserted that Canadian political economy provided a strong foundation for a neo-Marxist tradition because Innis had used the historical method to inquire into the material conditions of international and domestic colonialism. Panitch advocated a neo-

${ }^{68}$ Leo Panitch, “Editor's Preface," in The Canadian State: Political Economy and Political Power, ed. Leo Panitch (Toronto: University of Toronto Press), vii. 
Marxist framework that was not limited by narrow boundaries but on investigating the relationships between politics, economics, and culture. ${ }^{69}$

In his essay "The Role and Nature of the Canadian State," Panitch sought to outline how socialism and anti-imperialism were interconnected. He agreed with Horowitz's assertion that the Canadian state was unique because it did not follow the centralizing tendency outlined by Miliband. It was based on a "bi-national society" that was "quasi-colonial," with an economy dominated by central Canada along with a bourgeoisie that was dominated by imperial interests. This bourgeoisie was also characterized by "fragmented regional interests" and needed to contend with the "persistence of American capital."70 Turning to class relations, Panitch argued that the Canadian state operated according to the interests of an entrenched bourgeoisie dominated by the capitalist class, and wielding significant influence in political parties and the civil service. ${ }^{71}$ With regards to capital accumulation, Panitch asserted that the Canadian state had taken up four tasks. It provided a favourable economic climate for private enterprise; it stepped in to underwrite the risks of production in a sparsely populated staples economy; it performed a primary role in creating a capitalist labour market by absorbing the social costs of production through the creation of a welfare state; and it provided crucial infrastructure for capitalist development when private capital was not available (construction of railways, shipping lines, highways, hydroelectric projects). An overarching theme

\footnotetext{
69 Panitch, "Editor's Preface," viii.

${ }^{70}$ Panitch, "The Role and Nature of the Canadian State," 10.

${ }^{71}$ Ibid., 11.
} 
was the state's willingness to intervene to ensure the proper development of a resource extraction-based economy. ${ }^{72}$

Addressing the uniqueness of the staples economy, Panitch proposed that the Canadian state was never laissez-faire like its American and British counterparts. In contrast to Horowitz's identification of a unique Canadian state ideology, Panitch concentrated on economics. He argued that the state ownership of railroads and public utilities was never "undertaken as an end in itself to manage or control the economy, but always to facilitate further capital accumulation in the private sphere to the end of economic growth."73 The Canadian state was much more involved in capital accumulation than the American or British, but only because it needed to step in where the private sector was unable to ensure profitable enterprise operating within a staples economy. In Canada, a well-developed financial capitalist class existed alongside a fragile industry-owning class that was subservient to foreign industrial empires due to the nature of the staples economy. In this process, the Canadian state lost its autonomy and became effectively subservient to the interests of the capitalist class. This observation outlined the peculiar nature of Canadian political economy. It was Panitch's answer to the staples question.

Panitch argued that the relative lack of autonomy of the state, along with a weak indigenous industrial-based middle class, created another problem in the Canadian political economy: the persistence of foreign capital. Displaying the left nationalism prevalent within contemporary Canadian political economy, Panitch

\footnotetext{
72 Panitch, "The Role and Nature of the Canadian State," 14.

${ }^{73}$ Ibid.
} 
argued that both the financial and industrial bourgeoisie in Canada sought to build, with the aid of the state, a viable national economy that was not dependent on staples extraction for imperial markets. ${ }^{74}$ In doing so, the industrial sectors had to rely on American capital investment, which produced the opposite of the intended result, the replacement of a staples economy dependent on imperial Britain with one based on the "American Empire." Echoing the concerns of conservative intellectuals such as Innis, Panitch advanced the left nationalist claim that, following independence from Britain, American investment flooded into Canada with the aid of the state and financial bourgeoisie. With it, any hope of an economic basis for independence was lost. ${ }^{75}$

Panitch's left nationalism was further evidenced by his contention that foreign investors were treated the same as domestic ones, with the result that economic growth was "removed from the Canadian state" because of the "sheer dominance of foreign capital over the economy much of the substances of [Canada's] political sovereignty was removed with it." Panitch made it clear that he subscribed to the views of contemporary left nationalists when he concluded that "in Canada's voyage from colony to nation to neo-colony we seem to have exchanged the shadowy and unreal independence offered within the British Empire for that of independence tolerated by the Americans." 76

\footnotetext{
${ }^{74}$ The distinction between an industrial and financial bourgeoisie was first put forward by R. T. Naylor to elaborate upon the peculiarities of Canadian political economy and political culture based on staples extraction. See R. T. Naylor, "The Rise and Fall of the Third Commercial Empire of the St. Lawrence," in Capitalism and the National Question in Canada, ed. Gary Teeple (Toronto: University of Toronto Press, 1972), 1-42.

${ }^{75}$ Panitch, "The Role and Nature of the Canadian State," 18.

${ }^{76}$ Ibid.
} 
Reginald Whitaker continued Panitch's practice of studying Canadian economic history to prosecute class struggle and reinvigorate socialism. In his essay in The Canadian State: Political Economy and Political Power, titled "Images of the State in Canada," Whitaker provided a historical overview of the development of the Canadian state. Whitaker agreed with Horowitz's assertion that Canada originated as a transplanted society. The ideological and political legacy of the colonial period directly shaped the image of the Canadian state in the twentieth century. Whitaker argued that there were clear distinctions between liberal laissez-faire and Tory conception of the state, with the former becoming hegemonic in Britain by the midnineteenth century, while the latter gained prominence in Canada. Where liberals desired the state to keep out of economic affairs, only intervening in the social and moral lives of individuals in order to ensure social harmony and order, Toryism placed an emphasis on national over individual interests and underwrote traditional institutions like the church and monarchy and communities made up of distinct and rigid classes. To achieve this, Tories supported state intervention in the economy to regulate the market. Canada, where a capitalist economy and communities were established in the absence of a feudal past, was naturally more inclined to embrace the Tory model. ${ }^{77}$ In Whitaker's analysis, there was a profound change in its role during the $19^{\text {th }}$ century when a centralized, bureaucratic nation-state rose up, dominated by a transplanted professional and commercial middle-class. ${ }^{78}$

77 Whitaker, "Images of the State in Canada," 31-32.

${ }^{78}$ Ibid., 28-29. 
Whitaker acknowledged that the traditional Marxist interpretation of the capitalist state, specifically its separation into accumulation, legitimation, and coercion functions, was not easily applied to his study of the image of the Canadian state. Nevertheless, as a committed neo-Marxist, Whitaker used his study of the role of culture and experience in determining images of the state to define the historical trajectory of the Canadian state's legitimation function. Marxists focus their attention on what contributes to capital accumulation and the development of capitalism through history. In contrast, Whitaker proposed that, to grasp the state's legitimation function, it was essential to understand what the people thought was right and how the state convinced people that it had legitimate authority. To take up a Marxist intellectual history of conceptions of the state, it was crucial that its accumulation and legitimation functions were not separated into isolated spheres. ${ }^{79}$ For Whitaker, it was the "interrelation" of these functions where the specifics of the Canadian state were determined.

Culture and ideology played a central role in Whitaker's neo-Marxian analysis of the emergence of the class system in Canada and of the manner in which the Canadian state emerged as a mediator between the interests of class and capital. This mediator function served to preserve the bourgeoise in power and prevented the creation of a socialist state. Whitaker argued that in colonial Canada the bourgeoisie emerged out of a deliberate policy of the imperial and colonial state apparatus. With the absence of a feudal history like Europe, the traditional Marxist trajectory of history could not take place in what was to be English Canada.

${ }^{79}$ Whitaker, "Images of the State in Canada," 30. 
According to Whitaker, the "indigenous roots of the bourgeoisie" were from the beginning closely linked to an "imperialist-mercantilist framework which established and nurtured its exotic roots in new soil." Therefore, the history of colonial Canada was characterized by an interaction of a series of visions, plans, and dreams of the ideal society, with the harsh reality of their being a lack of resources and capital to bring them to fruition. ${ }^{80}$ As a result, the Canadian colonial state was born out of a project to foster the development of a bourgeoisie that would gain hegemony in an environment that was hostile to the organic development of capitalism.

Whitaker and his neo-Marxist contemporaries were as concerned with the failure of social democracy as they were with a theoretical analysis of the state. Their investigation of the nature of the Canadian state was ultimately based on a desire to probe the reasons for the continued dominance of capital and bourgeoisie interests at the expense of the working classes in Canada. Whitaker summarized the theory of the Canadian state by writing that "Toryism established the state, liberalism consolidated it, and social democracy misjudged it." It was vital, he said, for socialists to understand the particularly Canadian form of the capitalist state, and to move beyond ideology to see the state as an agent of capitalist interests. He concluded with a question for Canadian neo-Marxist academics: "with our backs turned to the future and our eyes fixed upon the wreckage of the past, the question is, as always: what is to be done?" 11

${ }^{80}$ Whitaker, "Images of the State in Canada," 34-35.

81 Ibid., 66. 
Tom Traves', in his contribution to Panitch and Watkins' State and Economic Life Series, The State and Enterprise: Canadian Manufacturers and the Federal Government (1979), did not explicitly describe the close association between the Canadian state and the industrial classes as state capitalism. He did, however, identify the emergence of a "modern interventionist state" in the early $20^{\text {th }}$ century that was a product of the federal government's unique relationship with manufacturers. Traves wrote that "the history of Canadian manufacturing cannot be understood outside the context of the complex institutional arrangement that businessmen and legislators created to promote, protect, and regulate industrial enterprise. However, they deserve attention for the light they throw to the overall role of the state in a mature capitalist political economy." ${ }^{82}$

Traves contended that by the First World War, Canadian manufacturers had relied on the state to assist them by implementing measures to protect established markets, such as the National Policy, and encouraged new areas of enterprise, such as providing finance for railways and other industries. In addition to the trend towards the consolidation of manufacturing into large businesses, there was a geographic centralization of the economy in Ontario, and the industrial leadership joined ranks with the commercial and financial elite in playing a dominant role in Canadian politics. ${ }^{83}$ Traves argued that there had historically been a tendency for conflict between and within classes. The political economy and state structure of the 1970s was a product of this conflict and the state's attempt to contain or mediate it.

\footnotetext{
82 Tom Traves, The State and Enterprise: Canadian Manufacturers and the State, 1917-1931 (Toronto: University of Toronto Press, 1979), 5.

83 Ibid.
} 
Traves concluded by defining the true nature of the Canadian state. The Canadian state was "a structure of institutional power relationships, within which class and group interests establish the compromises required to perpetrate the capitalist order in Canada." ${ }^{84}$ However, Traves asked, if this was the institutional definition of the state, then what of the political parties that had competed for control of it and what of the working class?

Directly influenced by these frameworks and insights provided by Panitch and Traves, Paul Craven's 1980 “An Impartial Umpire': Industrial Relations and the Canadian State, 1900-1911, another volume in the Panitch and Watkins series, provided a detailed analysis of Canadian industrial relations policy at the beginning of the $20^{\text {th }}$ century and the distinctive features that characterized it well into the 1980s. Craven argued that the staples economy had immediate consequences for class organization, such as the "regional fragmentation of labour" and the state's relatively active role in capital accumulation. Regional fragmentation led to a particularly Canadian tendency by both organized labour and organized business to turn to the state for help with their problems. Since economic prosperity was based upon the state's willingness to provide economic security, neither the Canadian Manufacturers Association nor the Canadian Labour Congress had any interest in importing techniques that would threaten the role of the state. The staples economy both undermined and strengthened the foundations of the state. While having to rely on foreign capital and having to be particularly concerned with ensuring social harmony and efficient capital accumulation, the forces that could undermine the

84 Traves, The State and Enterprise, 167. 
state's authority, such as organized labour, became dependent on the state. ${ }^{85}$ This was Craven's answer to the neo-Marxist question of why social democracy failed to bring about any change in the state system.

\section{Phillip Resnick: Class and Nationalism}

Socialist political scientist Philip Resnick offered a comprehensive study of why Canada did not gain its economic independence or become socialist. Looking back at the rise of nationalism in Canadian politics and academia in the late 1960s and early 1970s, Resnick sought to interpret these developments using a conventionally Marxist class-based analysis in his 1977 study, based on his PhD thesis, The Land of Cain: Class and Nationalism in English Canada, 1945-1975. Methodologically, Resnick approached the study of Canadian nationalism through a class analysis that was mediated through the broader context of "imperial" (meaning Canadian-American) relations in the post-Second World War period. Despite the many contradictions in Marxism, which were being dealt with by the neo-Marxists, Resnick argued that a Marxist theory of imperialism took into account the transformation of capitalism since Marx's time. By this Resnick meant the internationalization of capital, the emergence of the multinational corporation, and the unequal relations between developed and underdeveloped producers. Resnick advocated a class-based analysis of Canadian nationalism because the Marxist

85 Paul Craven, “An Impartial Empire:" Industrial Relations and the Canadian State, 1900-1911 (Toronto: University of Toronto Press, 1980), 360-1. 
approach recognized that in "class divided societies, such as our own, political ideas

are rooted in economic relations." 86 Resnick also quoted Marx and Engels:

The ideas of the ruling class are in every epoch the ruling ideas, [such as] class, which is the ruling material force of society, is at the same time its ruling intellectual force. The class which has the means of material production at its disposal, has control at the same time over the means of mental production, so that thereby, generally speaking, the ideas of those who lack the means of mental production are subject to it. ${ }^{87}$

Canada was divided into different classes, all of which had a stake in perpetrating or countering Canada's political economy of American dependency.

Resnick also addressed how most socialist and nationalist political agendas were fundamentally incompatible, or outright anti-democratic. ${ }^{88}$ Resnick took a contrary view, arguing that nationalism could be used as a tool to rally different classes to a socialist agenda.

Yet such a reading of nationalism is neither very dialectical nor profound. For if nationalism poses a challenge to socialist theory and even a threat, as the wholesale collaboration of social democratic parties with their respective governments at the outbreak of World War One illustrated, it also provides an opportunity. In the case of an oppressed or dominant specialist, the struggle for national liberation can be at the same time an opening wedge for social revolution, [such as] China, Vietnam, Yugoslavia, and partisans fighting the Nazis. ${ }^{89}$

Resnick equated Canada's situation of dependence on the United States to that of independence movements throughout the world that were led by leftist forces. It is likely that Resnick saw an opportunity in the growing concerns about American

\footnotetext{
${ }^{86}$ Philip Resnick, The Land of Cain: Class and Nationalism in English Canada, 1945-75 (Vancouver: New Star Books, 1977), 20.

${ }^{87}$ Karl Marx and Frederick Engels The German Ideology (New York: International Publishers, 1970, reprint), 64. Cited in Ibid., 21.

88 Ibid., 21.

${ }^{89}$ Ibid., 22.
} 
dependence to ally the political interests of the working classes and the petty bourgeoisie against the Canadian capitalist state.

Resnick was a staunch anti-capitalist. In his Marxist class analysis of English Canadian nationalism in the 1960s and 1970s, Resnick blamed the rise of the multinational corporation after the 1950s for lessening the capitalist class' sympathy for a nationalist agenda or state intervention. This development came in the form of the rise of the Canadian multinational corporation, mostly in the transportation and financial sectors, which were historically well-developed in Canada. As evidence of the hostility of the Canadian multinationals to any nationalist agenda, Resnick highlighted the comments made by the president of MacMillanBloedel, who attacked the "dilettantes who espouse the narrow nationalisms of the separatists and the neurotic left." ${ }^{\prime 0}$ Creating Canadian multinationals might solve the dependence problem, but for Resnick, corporations were the problem, blocking any political agenda that does did not directly benefit their interests. This point was further evidenced by the Canadian Manufacturers Association's declaration that it did not have a problem with multinationals operating in Canada as long as Canadian manufacturers were given the ability to compete. ${ }^{91}$ Socialists would never expect corporations to support their agenda; instead, Resnick had high hopes for the petty bourgeoisie, which he identified as the leaders of the English Canadian nationalist movement.

${ }^{90}$ Resnick, The Land of Cain, 152.

${ }^{91}$ Ibid., 154. 
According to Resnick, the petty bourgeoisie played a decisive role in the rise of English Canadian nationalism after 1965. This class was made up of salaried professionals, many of whom were civil servants, or working for universities and schools, and research institutes, or university students. This class emerged out of the rise of the public sector and higher education in the 1960s. ${ }^{92}$ Resnick correctly pointed out that members of this class (the "new petty bourgeoisie") dominated the two key nationalist organizations during this period, the moderate Committee for an Independent Canada (CIC) and the leftist Waffle movement. ${ }^{93}$ Resnick also argued that the publications by members of this class, such as those produced by the New Canadian Political Economy, gave "ideological direction and coherence to the nationalist movement." The English Canadian nationalists of the petty bourgeoisie were concerned with Canada's lack of an independent foreign policy and growing economic dependence on the United States. However, according to Resnick, this class had a vested interest in strong state institutions, which the nationalist movement sought to strengthen through its agenda of intervention in the economy. Resnick quoted Watkins as proof of this claim. Watkins insisted that "the

\footnotetext{
92 Resnick, The Land of Cain, 167.

${ }^{93}$ Resnick provided valuable statistics on the professional and class makeup of the Waffle and CIC: "Where the Waffle was concerned, fully twenty-one per cent of its members were students, eight per cent were teachers, ten per cent professors, and ten per cent professionals, with many of these presumably salaried professionals in either the private or public sectors. The Waffle's main leaders, Mel Watkins and James Laxer, were from the same [petty bourgeoisie] class. The CIC's original steering committee included thirty-two academics, ten students, ten journalists and broadcasters, and five to six professional politicians, [which] constituted a near majority of its one hundred twentymember committee. Two of its three godfathers, Peter Newman and Abraham Rotstein, were from the new petty bourgeoisie, with only Walter Gordon representing the dominant class in Canada." Ibid., 170-71.
} 
nationalists must see that the only effective alternative to high and rising foreign ownership is the steady expansion of Canadian public ownership." 94

In Resnick's interpretation, the nationalist agenda was driven by the class interests of the petty bourgeoisie, just as the interests of the big bourgeoisie drove the anti-nationalist cause. The outcome of the nationalist political agenda would depend on the class struggle in which it emerged. Socialists like Resnick, well versed in the scholarship on the Canadian state and class relations being produced by the neo-Marxists, could hope that, if the Canadian state could not resist American dependence because of its colonial nature, then perhaps class struggle was the answer. The neo-Marxist and socialist scholars did reveal, however, that Canada's dependence on the United States was the result of a myriad of historical and contemporary political and economic factors, with no easy solutions to the problems that arose from those factors. Out of this struggle to define the Canadian state and the role of class relations in the rise of nationalism, the neo-Marxists developed a new Canadian school of political economy that examined the peculiar nature of the Canadian capitalist state and described the origins of the problem of Canadian political economy.

\section{Conclusion}

Like their counterparts in the Canadian left nationalist movement, Canadian neo-Marxists, represented in this chapter by Horowitz, Naylor, Whitaker, Panitch, Clement, Traves, and Craven, challenged prevailing neo-classical orthodoxies

\footnotetext{
${ }^{94}$ Resnick, The Land of Cain, 170.
} 
through a critique of the capitalist system that underpinned the problems of Canadian political economy and the lack of a socialist tradition in Canada. Guided by neo-Marxist theories of economics and the state, these left nationalists in the NCPE argued that the staples-based economy was responsible for the nature of Canada: an advanced and prosperous economic system that was dependent on foreign ownership of resources and industry. With a new emphasis on studying the reasons for and consequences of a lack of socialism in Canada, a new group in the NCPE led by Panitch sought to move beyond the politics of anti-imperialism which consumed the left nationalist moment. The NCPE, like the wider left nationalist movement, was a combination anti-imperialists and socialists. All members agreed that the ultimate goal was to create an independent and socialist Canada.

The New Canadian Political Economists took steps to cement their position within the Canadian academy. After the Waffle's demise Daniel Drache, a prominent left nationalist writing in the early 1970s, organized like-minded neo-Marxists scholars in an attempt at maintaining the left nationalist intellectual tradition and influencing politics. Notably, he helped found the Political Economy section of the Canadian Political Science Association which brought together leftists, left nationalists and neo-Marxists, ensuring that the NCPE would remain a major force in academia. ${ }^{95}$ Later in 1979, neo-Marxists active in the NCPE founded the peerreview journal Studies in Political Economy: A Socialist Review as a voice for likeminded scholars who were excluded from publication in the Canadian Journal of Political Science and address concerns about the lack of left intellectuals active

${ }_{95}$ Hurl and Christensen, "Building the New Canadian Political Economy," 185. 
within the NDP after the expulsion of the Waffle earlier in 1973. ${ }^{96}$ Ultimately, despite the inability of the NCPE to directly influence the NDP, which was wary of associating itself with left nationalists or those labelling themselves neo-Marxist, they were successful in establishing a new school of political economy that was neoMarxist and to the left of mainstream politics and neo-classical economics.

The neo-Marxists of the New Canadian Political Economy sought to renew the Canadian left, both academically and politically, by introducing neo-Marxist theories and practices into the Canadian intellectual and political frame of reference. At the same time that left nationalists were creating a new socialist movement in Canada, political economists and historians sympathetic to their cause established the new neo-Marxist school of thought in Canadian political economy. By the 1970s, left nationalists subscribed to the view that Canada's economy was in a state of dependency on the United States. The Canadian state, dominated by the multinational corporations, dependent on foreign capital, and controlled by a business class in the thrall of both, was colonial because it was capitalist. Only by replacing capitalism with socialism could Canada gain and retain its political and economic independence from the United States.

\footnotetext{
${ }^{96}$ In the 1979 inaugural edition of Studies in Political Economy: editors Wallace Clement and Mel Watkins wrote, "political economy refers to an interdisciplinary blend of the history of economic, political and cultural relations. In Canada, political economy has an established meaning, referring both to an indigenous liberal, yet unorthodox, tradition ... and to a smaller but highly creative Marxist traditions ... us, as socialists, political economy refers to a tradition of inquiry which, while not Marxist in origin nor exclusively Marxist today, is now being increasingly integrated with the theoretical tradition of historical materialism.....as socialists, we not only hope but expect that this Journal will, directly and indirectly, contribute to the on-going and diverse activities of the left and the working-class movement; to be scholarly is also to be relevant in informing practice." Wallace Clement and Mel Watkins, "Editorial Statement," Studies in Political Economy: A Socialist Review 1 (spring 1979), iv.
} 


\section{Conclusion}

"Radical solutions always seem improbable, but nothing else seems to work," Mel Watkins told Walter Stewart in November 1970 on the eve of the fateful NDP leadership campaign. ${ }^{1}$ In justifying his left nationalist politics, Watkins offered a hint of acknowledgment that the Waffle's agenda might appear too radical for mainstream acceptance, let alone for the members of the NDP. Nevertheless, fresh from the ideological battles that surrounded the launch of the Waffle Manifesto at the 1969 convention, Watkins was clear in his prognosis. Canada, he argued, was threatened by too much American control over the economy. Only by dismantling capitalism and rebuilding the country as a democratic socialist state could Canada regain its independence. For Watkins and other left nationalists, independence could only be achieved through socialism because the "political parties which represented Canadian business could not be relied upon." ${ }^{2}$

Left nationalists advanced the politics of democratic socialism and antiimperialism. They viewed the United States as a declining empire. They believed Canada's relationship to the United States was colonial and Canada's prosperity and natural resource wealth was threatened by American dependency and decline. Left nationalists extended their activism to the academy and founded the New Canadian Political Economy, which sought to advance socialism by introducing neo-Marxism into the study of Canadian political economy and history.

\footnotetext{
${ }^{1}$ Walter Stewart, "On the Left, Mel Watkins. In the Middle, Joe Greene. The Heavyweight Contest to Choose Captain Canada of 1971," Maclean's, November 1, 1970, 35.

2 Mel Watkins, "The Waffle and the National Question," Studies in Political Economy 32 (1990), 173.
} 
Watkins described the left nationalist movement in similar terms: "in the era of the American war in Vietnam and of the New Left as global phenomenon, we translated anti-war and anti-corporate sentiment into Canadian nationalism.." ${ }^{3}$ In rejecting old leftist politics and embracing anti-imperialism, left nationalists hoped to preserve Canada's independence from the American Empire. In their writings, left nationalists pursued the common goal of remaking Canada into a democratic socialist state, free from American ownership of resources and major industries, and free from capitalism. Within the movement, there was a diversity of opinion over the extent to which its agenda of liberation and socialism should be carried out. All agreed, however, that Canadian independence could not be ensured without socialism. Through the Waffle Manifesto, left nationalists sought to remake the NDP in their own image, solve the problem of American dependence, and assert the country's economic, political, and ecological independence from the United States.

Reflecting on nearly two decades of nationalist politics, the political scientist Burton M. Smith wrote in 1978 that "anti-Americanism has always been a popular theme with Canadian nationalists." ${ }^{4}$ Anti-Americanism may work as a characterization of New Nationalism; however, it is not an effective allencompassing description of the premise of left nationalism. Some left nationalists, such as James Laxer and Mel Watkins, held some unsavoury opinions of facets of American politics and society, but their political project was premised on the idea that the United States was an empire and Canada needed to be liberated from it. Left

\footnotetext{
3 Watkins, "The Waffle and the National Question," 173.

${ }^{4}$ Burton M. Smith, "The United States in Recent Canadian Nationalism," World Affairs 140, no. 3 (Winter 1978), 195.
} 
nationalists were against the politics and economics of capitalist imperialism. An independent Canada meant liberation from the status as a colony to the American empire. Describing left nationalism as simply an extension of a wider English Canadian anti-American nationalism is a simplification that does not properly contextualize the movement as part of the wider politics of the New Left and debates over neo-Marxist theory. Left nationalists did indeed base their politics on what they were against, including imperialism and capitalism, but they also premised their agenda on what they were for: democratic socialism, political, economic and ecological independence, and a neo-Marxist school of thought.

Left nationalism was distinctive from other English Canadian nationalists active during the 1960s and 1970s. Nationalists agreed that Canada should be independent. The question was whether the country would remain capitalist or become socialist. The left nationalists were disrupters, not happy with the status quo or the main political parties. They rejected a program of reform, which meant that they were often in contention with others in the wider nationalist movement. The New Nationalists were a diverse cast of characters, but most agreed that Canada should not be remade as a socialist state and its place in the world should not be fundamentally altered. Left nationalists such as Mel Watkins, James Laxer, and Cy Gonick referred to the New Nationalists as representing the capitalist dimension of nationalism, or sell-outs advocating half measures such as the Foreign Investment Review Agency. Nevertheless, left nationalists were resentful or frustrated that the moderate brand of nationalism held sway during the 1970s. They were skeptical that reforming capitalism by encouraging the growth of Canadian-owned business 
or by diversifying trade patterns would free Canadian from its colonial relationship with the United States. Not all New Nationalists were capitalists, however. Abraham Rotstein advocated Swedish functional socialism as an alternative to capitalist reform, to buying back the Canadian economy, and to the left nationalism of the Waffle Manifesto.

A neo-Marxist worldview situated Canada in the global hierarchy of nations. Neo-Marxists and dependency theorists viewed international relations as based on competition for resources and exploitation of labour, with core nations extracting wealth from the periphery. They argued that periphery countries were trapped in a cycle of dependence with the core. Left nationalists also adapted dependency theory to the Canadian case. The United States was an imperial power, they argued, and Canada was its colony, however defined. The main cause of this situation, according to left nationalists, was American dependency. The desire to end Canada's colonial status was at the forefront of the left nationalist agenda.

The New Canadian Political Economists (NCPE) were influenced by, or active in, the left nationalist movement. They were academics who were primarily concerned with Canada's dependence on the United States and the factors that perpetrated it. Watkins, who declared that Canada was in a "staples trap," argued that Canadian political economy suffered from a colonial mentality. Writing on this subject in the mid 1960s, Watkins believed that Canadian economists were unable to conceive of an alternative to the country's reliance on foreign trade and investment. The NCPE sought to change that by introducing a modified form of dependency theory into the academy and seeking out how Canada became a 
dependent economy that enjoyed a high standard of living. By understanding how Canada developed under dependency and how the state was complicit, the NCPE hoped to develop a means of addressing the problem of American dependency and the staples trap.

The NCPE is one of the most enduring, albeit contested, legacies of left nationalism in Canada. Its neo-Marxist approach to studying the Canadian economy was firmly established in the academy in the proceeding decades and provided a counter-balance to the neo-classical school of thought later known as neoliberalism. Members of the NCPE founded the journal Studies in Political Economy: A Socialist Review in 1979, which aimed to counter the prevalence of neo-classicalism in the academy and disseminate left nationalism and neo-Marxism. Wallace Clement, a prominent member of the NCPE, wrote that Watkins' and the NCPE's greatest contribution to political economy was a reconsideration of Harold Innis's Staples Thesis. ${ }^{5}$ Watkins, and later the NCPE, sought to confront Innis's 1948 assertion that "Canada has had no alternative but to serve as an instrument of British imperialism, and then of American imperialism." ${ }^{6}$ In an age characterized by nationalist fervour and New Left politics, Watkins reintroduced and re-interpreted Innis, and argued that there was an alternative to Canada as an instrument of imperialism. That alternative was socialism.

\footnotetext{
${ }^{5}$ Wallace Clement, "Introduction: Mel Watkins and the Foundations of the New Canadian Political Economy," in Staples and Beyond: Selected Writings of Mel Watkins, ed. Hugh Grant and David Wolfe (Montreal: McGill-Queen's University Press, 2006), xiv-xx.

${ }^{6}$ Harold Innis quoted in Clement, "Introduction," xx.
} 
In the late 1970s, left nationalism threatened to become an encumbrance for the New Canadian Political Economy. "Younger voices," identified by Gregory Albo as a new generation of academics and activists who were too young to have been involved in the Waffle, found it hard to relate to the veterans of the movement, who seemed inclined to maintain old battles and disagreements. ${ }^{7}$ A notable example was Larry Pratt, one of the new generation of political economists influenced by left nationalism. He was surprised by the criticism levelled at his book Prairie Capitalism, ${ }^{8}$ a study of the similarities in economic policy between the Blakeney NDP government in Saskatchewan and the Lougheed Conservatives in Alberta. At a meeting at York University in 1979, Watkins, Laxer, Daniel Drache, and Philip Resnick ("the big pooh-bahs of left nationalism," as Pratt described them), were contemptuous of his findings, describing the book as dangerous and flawed because it did not recognize the importance of left nationalism for the economics of western Canada. ${ }^{9}$ The episode indicated that left nationalists risked their legacy and influence by being rigid and dogmatic. Pratt's co-author and former Waffler John Richards was disillusioned by the experience and turned away from studying Canadian political economy, explaining that he did not want to fight the "quasiMarxist economists represented by Mel Watkins and James Laxer. They are bright

\footnotetext{
7 Gregory Albo, "Canada, Left Nationalism, and Other Voices," Studies in Political Economy 33 (Autumn 1990), 164.

${ }^{8}$ Larry Pratt and John Richards, Prairie Capitalism: Power and Influence in the New West (Toronto: McClelland and Stewart, 1979).

${ }^{9}$ Pratt recalled: "We both saw this enormous regionalism, economic regionalism, developing in the west. Left nationalism couldn't account for that. Left nationalism was just a residue of foreign investment, that's all it is. It's not interesting in its own right." Jeremy Mouat, "Thinking About Prairie Capitalism: Interviews with Larry Pratt and John Richards," Aurora Online, Issue 2005, accessed January 7, 2020, http://aurora.icaap.org/index.php/aurora/article/view/1/1
} 
people, but I think they exaggerated the cultural differences between Canada and the United States." 10

New Democrats also had bitter memories of their experiences with the Waffle and left nationalism. Watkins was aware of this problem and remarked that many NDP members did not want to associate with the NCPE because "almost everybody involved in it had been to the left of the NDP and had been more Marxist than the NDP. So, the NDP doesn't even relate to it." Watkins speculated that the NDP's negative experience with left nationalism led to a "complete break" with the intellectual community, many of whom remained committed to disseminating left nationalist ideas in the academy. ${ }^{11}$ Watkins further claimed that the NDP's expulsion of the Waffle in 1973 "turned off a generation of activists," an opinion that was shared by Gonick. ${ }^{12}$

Despite these misgivings, Watkins and Laxer did not disassociate themselves from the NDP or public life. Laxer advised the Ontario NDP in the 1975 provincial election and was policy director for Michael Cassidy who won the Ontario NDP's leadership running on a left-wing platform in 1975 . He also briefly served as the federal NDP research director but resigned in 1983 over a series of disagreements with the leadership, describing the party's economic policy out of date. ${ }^{13}$ Watkins, while devoting most of his time to academics, later returned to the NDP and ran unsuccessfully as a candidate in the riding of Beaches-East York in the 1997 and

\footnotetext{
10 Mouat, "Thinking About Prairie Capitalism."

11 Cameron Smith, Unfinished Journey: The Lewis Family (Toronto: Summerhill Press, 1989), 443.

12 Ibid.

13 Michael Laxer, “James Laxer: Canadian Iconoclast.” Rabble.ca. https://rabble.ca/blogs/bloggers/rabblecas-staff-blog/2018/02/remembering-james-laxercanadian-iconoclast
} 
2000 federal elections, explaining that after the rise of neoliberalism it was "a luxury to imagine that you could be to the left of the NDP." ${ }^{14}$ Laxer enjoyed a long career as an academic, writer, and commentator, writing several books on politics, economics, and history based on nationalist or left-wing themes, many of which expressed a Marxist or anti-imperialist worldview. ${ }^{15}$ Notably, in 1986 he co-wrote and hosted the television documentary Reckoning: The Political Economy of Canada, where he presented a highly critical view of free trade, and for which he won a Gemini Award. Watkins and Laxer never attempted to re-launch a leadership bid or a new protest group like the Waffle.

NDP leaders later acknowledged there was truth to Watkins and Gonick's claim that there was a break between intellectuals and the party. On the twentieth anniversary of the Waffle Manifesto in 1989, some in the NDP leadership expressed regret over how events transpired in the ensuing years. The party failed to take a stand in the constitutional debates in the early 1980s, adopting what was criticized as a "me-too approach" that effectively ceded the party's position to the Trudeau Liberals. Even David Lewis lamented that "when the Waffle left the NDP, most of the brains left with them."16 Desmond Morton, a vehement critic of the Waffle, later admitted some regret over how the group was treated, writing that the NDP was "left to deal with a generation gap among its intellectuals and an apprehension to

\footnotetext{
${ }^{14}$ Smith, Unfinished Journey, 444.

${ }^{15}$ Some of Laxer's notable titles on left-wing themes include, In Search of a New Left: Canadian Politics After the Neoconservative Assault (Toronto: Viking, 1996); Stalking the Elephant: My Discovery of America (Toronto: Viking, 2000); and The Perils of Empire: America and its Imperial Predecessors (Toronto: Viking, 2007), where he made the case that the United States was a "capitalist empire" and remained an imperial power at the beginning of the 21st century.

${ }^{16}$ Reg Whitaker, "Introduction: The $20^{\text {th }}$ Anniversary of the Waffle," Studies in Political Economy 32 (1990), 168.
} 
engage in major policy debates." ${ }^{17}$ Both Wafflers and their opponents agreed that the conflict within the NDP over the Waffle Manifesto and left nationalism damaged the party and possibly discouraged a new generation of left activists.

While the 1970s were a decade of nationalism, the political trends of the 1980s were characterized by a rise of continentalism and a re-invigoration of neoclassical economics, now known as neoliberalism. While the Vietnam War had ended and the Trudeau government adopted moderate economic nationalist measures, the problems of Canadian political economy identified by the left nationalists remained. For Watkins, American dependency actually intensified during the 1980s because of what he saw as the failure of the Third Option and the overwhelming support of the business class for further economic integration with the United States in the form of a comprehensive free trade deal. For Watkins, the 1988 Canada-United States Free Trade Agreement was "the culmination of [the] Canadian slide into colonial status." ${ }^{18}$ He feared Canada's continental patterns of trade, which he argued was the main cause of American dependency, would be made permanent by the agreement. ${ }^{19}$

On the issue of free trade, Laxer agreed with Watkins that Canada remained a "dependency of the American economic system." Laxer argued that free trade was based on discredited neo-classical economics that caused industrial decline and globalization. Writing in 1986 in Leap of Faith: Free Trade and the Future of Canada, Laxer claimed that the American economy remained in decline as a result of

\footnotetext{
${ }^{17}$ Desmond Morton, NDP: The Dream of Power (Toronto: Samuel Stevens Hakkert, 1974, 1st ed), 155. ${ }^{18}$ Watkins, "The Waffle and the National Question," 175.

19 Watkins, “The US-Canada Free Trade Agreement," Monthly Review (September 1988), 39.
} 
deregulation and international competition. ${ }^{20}$ For Laxer, a free trade agreement would only tie Canada dangerously closer to a weakened United States. However, his solution to Canada's problems, and his alternative to free trade, was surprising. While remaining a committed anti-imperialist, Laxer seemed to have turned away from democratic socialism and expressed interest in the "national capitalist model," characterized by state planning of a free enterprise economy. ${ }^{21}$ Nevertheless, Laxer and Watkins insisted that free trade was detrimental to Canada, and both were frustrated at the failure of the NDP to effectively oppose the Free Trade Agreement when it was presented to voters at the 1988 federal election.

Watkins lamented the state of the NDP in the aftermath of the free trade debate and the 1988 federal election. He claimed the 1980s were a "thoroughly miserable decade of American truculence and bluster under Reagan and of Canadian retreat, first under Trudeau and then yet more so under Mulroney."22 Watkins also thought the NDP was ineffective in promoting its political agenda and questioned whether it was committed to any left-wing ideas. He thought that the NDP was unable to counter the reinvigorated conservative politics of President Ronald Reagan and Prime Minister Brian Mulroney or offer any alternative to arrest Canada's deeper course into the status of an American colony. Watkins described the NDP leadership as "bumbling" and unable to lead the opposition to free trade.

\footnotetext{
${ }^{20}$ James Laxer, Leap of Faith: Free Trade and the Future of Canada (Edmonton: Hurtig Publishers, 1986), 2.

${ }^{21}$ Laxer elaborated on the idea of national capitalism in Reckoning: The Political Economy of Canada in 1986. By this time, he was increasingly interested in the economic models used in France and other parts of Western Europe where the government regulated key sectors of the economy and worked with corporations in strategic planning. Ibid., 120-21.

${ }^{22}$ Watkins, "The Waffle and the National Question," 175.
} 
This, he felt, created an opening for Liberal Party leader John Turner to remake himself as a nationalist and lead the campaign against the Free Trade Agreement in the 1988 federal election. Watkins agreed with Abraham Rotstein's observation that "the NDP, unable to get anywhere in Quebec, demonstrated its inability to deal with the nationalist question in either official language." This, for Watkins, was part of the "continuing cost to the NDP of our expulsion."23

Watkins did not believe that left nationalism was dead as a political cause. During the 1980s the labour movement embraced nationalism, an example of which was the creation of the Canadian Autoworkers Union as a breakaway from the American-based United Autoworkers. Watkins saw this as a positive development because he blamed the American led unions, "in alliance with the Lewis family," as the main force behind the Waffle's expulsion from the NDP. This movement away from international unionism was precisely what left nationalists desired and Watkins hoped it would form the basis of a renewed left nationalism.

Watkins' assessment of the promise of the newly nationalist-inclined unions was accurate. Historian Steven High has demonstrated that nationalist Canadian unions were largely responsible for the lower extent of de-industrialization and better worker compensation compared to the United States. Union leaders used nationalist rhetoric to pressure the federal and provincial governments to legislate increased protections for workers and provide incentives to businesses to stop plant closures. $^{24}$

\footnotetext{
23 Watkins, "The Waffle and the National Question," 175.

${ }^{24}$ Steven High, Industrial Sunset: The Making of North America's Rust Belt, 1969-1984 (Toronto: University of Toronto Press, 2003), 169.
} 
In a further demonstration of their newfound nationalist credentials, unions, along with grassroots groups associated with the Pro Canada Network, organized a strong campaign against the Free Trade Agreement during the 1988 election. Watkins speculated on the Waffle's role in this development, writing in 1989 that, "we old Wafflers should all be happy if future historians see the Waffle as an embryonic version thereof." He concluded his retrospective of the left nationalist movement with the observation on its legacy. "Although we lost on free trade, we saw remarkable evidence of a strong left nationalist sentiment as recently as one year ago [1988]. Let us by all means emphasize the Waffle's contribution to that legacy. Tell me: who on the left has stronger claims?"25

The Waffle was the political arm of the wider left nationalist movement. It represented a unique part of the history of left-wing Canadian political thought and offered a new interpretation of Canada's economic relationship with the United States. Unable to take control of the NDP, the Waffle could be viewed as a political failure, but its legacy was carried forward by left nationalists writing about the country's relations with the United States, issues surrounding the exportation of energy and ecological independence, and neo-Marxist political economy. The Waffle was born out of a uniquely Canadian experience: the debate over how to deal with an over-bearing neighbour that the country relied on for so much of its prosperity. English Canadian left nationalists wanted Canada to reject its capitalist past and present and embrace a future as a socialist state that would be independent from the United States and prosperous. As Watkins put it: "in 1965 George Grant had

${ }^{25}$ Watkins, "The Waffle and the National Question," 176. 
written in Lament for a Nation that socialism could not be the salvation of Canada because Canadian socialist leaders 'had no understanding of the dependence of socialism and nationalism in the Canadian setting.' We were resolved to change that."26

\footnotetext{
${ }^{26}$ Watkins, "The Waffle and the National Question," 173.
} 


\section{Bibliography}

\section{Archival Collections}

Library and Archives Canada, Ottawa, Ontario

CCF-NDP Fonds

Ross Dowson Fonds

Eric Kierans Fonds

David Lewis Fonds

Clara Thomas Archives and Special Collections, York University, Toronto, Ontario

James Laxer Fonds

Leo Panitch Fonds

William Ready Division of Archives, McMaster University, Hamilton, Ontario

New Democratic Party Waffle Collection

\section{Newspapers and Periodicals}

Canadian Dimension, 1965-1975

Canadian Forum, 1968-1974

The Globe and Mail, 1968-1974

Last Post, 1971

The New Democrat, 1968-1974

This Magazine is About Schools, 1969

The Toronto Star, 1968-1974

Maclean's, 1968-1974

\section{Government Documents}

Berger, Thomas L. Northern Frontier, Northern Homeland: The Report of the Mackenzie Valley Pipeline Inquiry. Ottawa: Government of Canada, 1977.

"Gray Report." Herb Gray. Foreign Direct Investment in Canada. Ottawa: Government of Canada, 1972.

“Kierans Report.” Eric Kierans. Report on Natural Resources Policy in Manitoba. Winnipeg: Government of Manitoba, February 1973. 
McDougall, Ian et al., Economic Development with Environmental Security: A Brief Submitted to the Nova Scotia Representatives of the Canadian Council of Resources and Environment Ministers at Halifax on September 26, 1972.

"Shultz Report." The Oil Import Question: A Report on the Relationship of Oil Imports to the National Security, Cabinet Task Force on Oil Import Control. Washington, D.C.: U.S. Government Printing Office, 1970.

"Wahn Report." House of Commons, Eleventh Report of the Standing Committee on Defence and External Affairs Respecting Canada-U. S. Relations. Ottawa: Government of Canada, 1970.

"Watkins Report." Task Force on the Structure of Canadian Industry. Foreign Ownership and the Structure of Canadian Industry: Report of the Task Force on the Structure of Canadian Industry. Ottawa: Government of Canada, 1968.

\section{Films}

Canadian Cable Affairs Channel. "The NDP: A Party at the Crossroads." 2017. http://www.cpac.ca/en/programs/documentaries/episodes/90008058

CBC Archives. "Mulroney debates Turner on Free Trade." https://www.cbc.ca/archives/entry/mulroney-battles-turner-on-free-tradein-1988

Collister, Ron. "Manifesto for an Independent Socialist Canada Splits the NDP in 1969." https://www.cbc.ca/archives/entry/manifesto-for-an-independentsocialist-canada-splits-ndp-in-1969

Lewis, David. "Speech to NDP Convention," 1975. http://www.cbc.ca/archives/entry/david-lewis-says-farewell-at-the-ndpconvention

National Film Board of Canada. “Reckoning: The Political Economy of Canada.” 1986.

\section{Websites}

Socialist History Project: Documenting the Revolutionary Socialist Tradition in Canada. www.socialsithistory.ca

\section{Published Sources}

Abrams, Phillip. "Notes on the Difficulty of Studying the State." Journal of Historical Sociology 1, no. 1 (1988): 58-89. 
Adler-Karlsson, Gunnar. Reclaiming the Canadian Economy: A Swedish Approach Through Functional Socialism. Toronto: House of Anansi Press, 1970.

Aivalis, Christo. The Constant Liberal: Pierre Trudeau, Organized Labour, and the Canadian Social Democratic Left. Vancouver: UBC Press, 2018.

Albo, Gregory. "Canada, Left-Nationalism and Younger Voices." Studies in Political Economy 33 (Autumn 1990): 161-74.

Anastakis, Dimitry. Auto Pact: Creating a Borderless North American Auto Industry, 1960-1971. Toronto: University of Toronto Press, 2005.

----. "Between Nationalism and Continentalism: State Auto Industry Policy and the Canadian UAW, 1960-1970." Labour/Le Travail 53 (Spring 2004): 89-126.

Anastakis, Dimitry, ed. The Sixties: Passion, Politics, and Style. Montreal: McGillQueen's University Press, 2008.

Anderson, Benedict. Imagined Communities: Reflections on the Origin and Spread of Nationalism. London: Verso Books, 1983.

Anselmi, Manuel. Populism: An Introduction. London: Routledge, 2018.

Azzi, Stephen. Walter Gordon and the Rise of Canadian Nationalism. Montreal: McGillQueen's University Press, 1999.

----. "Foreign Investment and the Paradox of Economic Nationalism." In Canadas of the Mind: The Making and Unmaking of Canadian Nationalism in the Twentieth Century, edited by Norman Hillmer and Adam Chapnick, 63-88. Montreal: McGill-Queen's University Press, 2007.

Bélanger, Damien-Claude. Prejudice and Pride: Canadian Intellectuals Confront the United States, 1891-1945. Toronto: University of Toronto Press, 2011.

Bell, David A. "Political Columnists Think America is in Decline, Big Surprise." New Republic. October 7, 2010. https://newrepublic.com/article/78216/americain-decline-thomas-friedman.

Berger, Carl. The Sense of Power: Studies in the Ideas of Canadian Imperialism, 18671914. Toronto: University of Toronto Press, 1970.

Blair, David J. “Energy Security and Canadian Energy Policy: Independent Versus Collective Action." Journal of International Studies 11, no. 2 (June 1982): 130148.

Blocking, Richard. Canada's Water: For Sale? Toronto: James and Lewis, 1972. 
Bosquet, Michel. “The Energy Crisis Hoax." Canadian Dimension, April 1974: 7-9.

Bothwell, Robert. Alliance and Illusion: Canada and the World, 1945-1984. Vancouver: UBC Press, 2008.

Brewer, Anthony. Marxist Theories of Imperialism: A Critical Survey. London: Routledge, 199.

Bullen, John. "The Ontario Waffle and the Struggle for an Independent and Socialist Canada: Conflict within the NDP." Canadian Historical Review 83, no. 2 (June 1983): 188-215.

Campbell, Lara, Dominique Clement, and Gregory S. Kealey, editors. Debating Dissent: Canada and the Sixties. Toronto: University of Toronto Press, 2012.

Carr, D. W. Recovering Canada's Nationhood. Ottawa: Carr Publishing Company, 1971.

Carr, Graham. "All We North Americans": Literary Culture and the Continentalist Ideal, 1919-1939." American Review of Canadian Studies 17 (1987): 145-57.

Cassidy, Frank. "The Anti-Politics of the Anti-Nation." Canadian Forum, April 1972.

Churchill, David S. "Draft Resisters, Left Nationalism, and the Politics of AntiImperialism." Canadian Historical Review 93, no. 2 (2012), 227-60.

A Citizen's Guide to the Gray Report. Toronto: New Press, 1971.

Claeys, Gregory. Marx and Marxism. London: Pelican Books, 2018.

Clarkson, Stephen. An Independent Foreign Policy for Canada? Toronto: McClelland and Stewart, 1968.

Clement, Wallace, Continental Corporate Power: Economic Linkages Between Canada and the United States. Toronto: McClelland and Stewart, 1977.

-----. "Introduction: Mel Watkins and the Foundations of the New Canadian Political Economy." In Staples and Beyond: Selected Writings of Mel Watkins, edited by Hugh Grant and David Wolfe, xiii-xxv. Montreal: McGill-Queen's University Press, 2006.

Clement, Wallace and Daniel Drache. A Practical Guide to Canadian Political Economy. Toronto: J. Lorimer, 1978. 
Clement, Wallace and Mel Watkins. "Editorial Statement." Studies in Political Economy: A Socialist Review 1 (Spring 1979): iv-vi.

Club of Rome. The Limits to Growth: A Report for the Club of Rome's Project on the Predicament of Mankind. New York: New American Library, 1972.

Cook, Ramsay. The Maple Leaf Forever: Essays on Nationalism and Politics in Canada. Toronto: Macmillan, 1977.

Cormier, Jeffrey. The Canadianization Movement: Emergence, Survival, and Success. Toronto: University of Toronto Press, 2004.

Craven, Paul. "An Impartial Umpire:" Industrial Relations and the Canadian State, 1900-1911. Toronto: University of Toronto Press, 1980.

Cross, Michael S. "Canada and the American Empire." Canadian Forum, April-May 1970.

----.. "The Waffle or the Unions." Canadian Forum, April 1972.

----. The Decline and Fall of a Good Idea: CCF-NDP Manifestoes 1932 to 1969. Toronto: New Hogtown Press, 1974.

Doern, Bruce, and Glen Toner. The Politics of Energy: The Development and Implementation of the National Energy Program. Toronto: Methuen Publications, 1985.

Dos Santos, Theotônio. "The Structure of Dependence." In Readings in U.S. Imperialism, edited by K. T. Fann and Donald C. C. Hodges, 225-236. Boston: Porter Sargent, 1971.

Downey, Donn. “Eric Kierans, 90." The Globe and Mail, May 10, 2004.

Dow, Alistair. "Douglas: Buy Canada Back or Lose Sovereignty." Toronto Star, June $24,1968$.

Drache, Daniel. "The Canadian Bourgeoisie and its National Consciousness. In Close the 49th Parallel Etc.: The Americanization of Canada, edited by Ian Lumsden, 3-26. Toronto: University of Toronto Press, 1970.

-----. "Rediscovering Canadian Political Economy." Journal of Canadian Studies 11, no. 3 (August 1976): 3-18.

----. "The Crisis of Canadian Political Economy: Dependency Theory Versus the New Orthodoxy." Canadian Journal of Political and Social Theory 7, no. 3 (1983): 25-49. 
Eayrs, James. “The Road from Ogdensburg." Canadian Forum, February 1971, 36566.

Edwardson, Ryan. "Kicking Uncle Sam out of the "Peaceable Kingdom": English Canadian New Nationalism and Americanization." Journal of Canadian Studies 37, no. 4 (Winter 2002-2003): 131-150.

Eley, Geoff. Forging Democracy: The History of the Left in Europe. London: Oxford University Press, 2002.

Ferraro, Vincent. “Dependency Theory: An Introduction.” In The Development Economics Reader, edited by Giorgio Secondi, 58-64. London: Routledge, 2008.

"Five Seek the Leadership, but who will win the NDP?" Globe and Mail, April 17 1971.

Forbes, H. D. "The Canadian Political Economy Traditions: Kari Levitt, Silent Surrender." In Canadian Political Thought, edited by H. D. Forbes, 379-88. Toronto: Oxford University Press, 1985.

Fossum, John Erik. Oil, the State, and Federalism: The Rise and Demise of PetroCanada as a Statist Impulse. Toronto: University of Toronto Press, 1997.

Foster-Carter, Aidan. "Neo-Marxist Approaches to Development and Underdevelopment." Journal of Contemporary Asia 3, no. 1 (January 1973): 733.

Frank, Andre Gunder. Capitalism and Underdevelopment in Latin America: Historical Studies of Chile and Brazil. New York: Monthly Review Press, 1967.

----. On Capitalist Underdevelopment. New York: Oxford University Press, 1975.

Godfrey, Dave and Mel Watkins. Gordon to Watkins to You: A Documentary: The Battle for Control of Our Economy. Toronto: New Press, 1970.

Goldblatt, Murray. "Lewis Asserts His Command, No Pandering to the Waffle." Globe and Mail, April 26, 1971.

Gonick, Cy. "The Political Economy of Canadian Independence." Canadian Dimension, May-June 1967, 12-19.

----. “The Year of the Waffle!” Canadian Dimension, December-January 1969-1970, 5-6. 
-----. "Foreign Ownership and Political Decay." In Close the 49th Parallel Etc.: The Americanization of Canada, edited by Ian Lumsden, 43-74. Toronto: University of Toronto Press, 1970.

-----. “Liberal-izing Continentalism." Canadian Dimension, October-November 1970, 4-6.

-----. “Waffling in Ontario." Canadian Dimension, October-November 1970, 6.

-----. "The American Empire: The Long Descent." Canadian Dimension, NovemberDecember 1973: 16-23.

----. Inflation or Depression: The Continuing Crisis of the Canadian Economy. Toronto: James Lorimer, 1975.

----. Canada Since 1960: A People's History. Toronto: James Lorimer and Company, 2016.

Granatstein, J. L. Yankee Go Home? Canadians and Anti-Americanism. Toronto: Harper Collins, 1996.

Granatstein, J. L., and Robert Bothwell. Pirouette: Pierre Trudeau and Canadian Foreign Policy. Toronto: University of Toronto Press, 1990.

Grant, George. Lament for a Nation: The Defeat of Canadian Nationalism. Toronto: McClelland and Stewart, 1965.

Grant, Hugh, and David Wolfe. "Mel Watkins as Teacher, Scholar and Activist." in The Staple Theory @ 50: Reflections on the Lasting Significance of Mel Watkin's "A Staple Theory of Economic Growth." edited by Jim Stanford, 16-19. Ottawa: Canadian Centre for Policy Alternatives, 2013.

Gray, Herb. "Good Fences: Controlling Foreign Investment." Canadian Forum, June 1975.

Greer, Harold. "Beating the Waffle," Winnipeg Free Press, April 20, 1971.

Hackett, Robert. Pie in the Sky: A History of the Ontario Waffle. Monograph published as a special edition of Canadian Dimension, October-November 1980: 2-71.

Hall, Stuart. "Cultural Studies and Its Theoretical Legacies." In Cultural Studies. Edited by Lawrence Grossberg, Cary Nelson, and Paula Treicher, 277-286. London: Routledge, 1992.

Head, Ivan L. "The Foreign Policy of the New Canada." Foreign Affairs 50, no. 2 (January 1972): 237-52. 
Head, Ivan, and Pierre Trudeau. The Canadian Way: Shaping Canada's Foreign Policy, 1968-1984. Toronto: McClelland and Stewart, 1995.

Henderson, Stuart. Making the Scene: Yorkville and Hip Toronto in the 1960s. Toronto: University of Toronto Press, 2011.

High, Steven. Industrial Sunset: The Making of North America's Rust Belt, 1968-1984. Toronto: University of Toronto Press, 2003.

Hillmer, Norman. "O. D. Skelton and the North American Mind." International Journal 60, no.1 (Winter 2004-2005): 93-110.

Hillmer, Norman, and Adam Chapnick, "An Abundance of Nationalisms." In Canadas of the Mind: The Making and Unmaking of Canadian Nationalisms in the Twentieth Century, edited by Norman Hillmer and Adam Chapnick, 3-14. Montreal: McGill-Queen's University Press, 2007.

Holmes, John W. The Better Part of Valour: Essays on Canadian Diplomacy. Toronto: McClelland and Stewart, 1970.

-----. Life with Uncle: The Canadian-American Relationship. Toronto: University of Toronto Press, 1981.

Horowitz, Gad. Canadian Labour in Politics. Toronto: University of Toronto Press, 1968.

-----. "Notes on 'Conservatism, Liberalism, and Socialism in Canada." Canadian Journal of Political Science 2 (June 1978): 383-99.

Hunt, Andrew. "'When did the Sixties Happen?' Searching for New Directions," Journal of Social History 33, no. 1 (1999), 147-61.

Huntington, Samuel P. “The U. S.: Decline or Renewal?” Foreign Affairs 67, no. 2 (Winter 1988-89): 76-96.

Hurl, Chris, and Benjamin Christensen. "Building the New Canadian Political Economy." Studies in Canadian Political Economy 96, no. 1 (2015): 167-193.

Hutchenson, John. "The Capitalist State in Canada." In (Canada) Ltd.: The Political Economy of Dependency. Edited by Robert Laxer, 153-77. Toronto: McClelland and Stewart, 1973.

Jeffries, Stuart. Grand Hotel Abyss: The Lives of the Frankfurt School. London: Verso Books, 2016. 
Kavic, Lorne John, and Gary Brian Nixon. 1200 Days: A Shattered Dream, Dave Barrett and the NDP in British Columbia, 1972-75. Coquitlam, B. C.: Kaen, 1978.

Kellogg, Paul. Escape from the Staples Trap: Canadian Political Economy After Left Nationalism. Toronto: University of Toronto Press, 2015.

----. "Kari Levitt and the Long Detour of Canadian Political Economy." Studies in Political Economy 71 (Autumn 2005): 31-60.

Kennedy, Paul. The Decline and Fall of the Great Powers: Economic Change and Military Conflict from 1500 to 2000. New York: Random House, 1987.

Kohn, Vilma L. "The Oil Import Question: Research, Report, Reaction." Case Western Reserve Journal of International Law 3, no. 1 (1970): 88-105.

Lapierre, Laurier L. Essays on the Left: Essays in Honour of T. C. Douglas. Toronto: McClelland and Stewart, 1971.

Laxer, James. "The Americanization of the Canadian Student Movement." In Close the 49th Parallel Etc.: The Americanization of Canada, edited by Ian Lumsden, 275-86. Toronto, 1970.

----- “Editorial: Continental Energy: A Proposal." Canadian Dimension, April-May 1970: 5-6.

----. The Energy Poker Game: The Politics of the Continental Resources Deal. Toronto: New Press, 1970.

-----. "The Alienation of Canada's Resources: An Overview." Canadian Dimension, January-February 1971: 11-14.

-----. "The Greene-ing of Canada." In Independence: The Canadian Challenge, edited by Abraham Rotstein and Gary Lax, 138-55. Toronto: McClelland and Stewart, 1972.

-----. "Canadian Manufacturing and U.S. Trade Policy." In (Canada) Ltd.: The Political Economy of Dependency. Edited by Robert Laxer, 127-152. Toronto: McClelland and Stewart, 1973.

-----. "Introduction to the Political Economy of Canada." In (Canada) Ltd.: The Political Economy of Dependency, edited by Robert Laxer, 26-41. Toronto: McClelland and Stewart, 1973.

-----. The Energy Crisis. Toronto: Lorimer, 1974. 
----. Leap of Faith: Free Trade and the Future of Canada. Edmonton: Hurtig Publishers, 1986.

-----. In Search of a New Left: Canadian Politics After the Neoconservative Assault. Toronto: Viking, 1996.

----. The Perils of Empire: America and Its Imperial Predecessors. Toronto: Viking Canada, 2008.

Laxer, James, and Gerald Caplan. "Perspectives on Un-American Traditions in Canada." In Close the 49th Parallel, edited by Ian Lumsden, 138-155. Toronto: University of Toronto Press, 1970.

Laxer, James and Doris Jantz. "The De-industrialization of Ontario." In (Canada) Ltd.: The Political Economy of Dependency, edited by Robert Laxer, 127-52. Toronto: McClelland and Stewart, 1973.

Laxer, James, and Robert Laxer. The Liberal Idea of Canada: Pierre Trudeau and the Question of Canada's Survival. Toronto: Lorimer, 1977.

Laxer, James, and Arthur Pape. "Youth and Canadian Politics." In Canada and Radical Social Change, edited by Dimitrios Roussopoulos, 48-54. Montreal, 1973.

Laxer, Michael. "James Laxer: Canadian Iconoclast." Rabble.ca. https://rabble.ca/ blogs/bloggers/rabblecas-staffblog /2018/02/remembering-james-laxercanadian-iconoclast/

Laxer, Robert, ed. (Canada) Ltd.: The Political Economy of Dependency. Toronto: McClelland and Stewart, 1973.

Laycock, David H. Populism and Democratic Thought in the Canadian Prairies, 19101945. Toronto: University of Toronto Press, 1990.

Levitt, Cyril. Children of Privilege: Student Revolt in the Sixties. Toronto: University of Toronto Press, 1984.

Levitt, Kari. Silent Surrender: The Multinational Corporation in Canada. Toronto: Macmillan of Canada, 1970.

-----. "Silent Surrender: Preface to the Carleton Library Series (2001)." Canadian Journal of Development Studies 24, no. 4 (2001): 579-589.

Lexier, Roberta. "Two Nations in Canada: The New Democratic Party, the Waffle Movement, and Nationalism in Quebec." British Journal of Canadian Studies 30 (2017): 1-22. 
Leys, Colin. The Rise and Fall of Development Theory. Indianapolis: Indiana University Press, 1996.

Litt, Paul. Trudeaumania. Vancouver: UBC Press, 2016.

Livingston, John A. "Neo-Nationalism and Ecological Independence." In Independence: The Canadian Challenge, edited by Abraham Rotstein and Gary Lax, 156-61. Toronto: McClelland and Stewart, 1972.

Macpherson, C. B. "Marxism in Canada: A New Beginning." Canadian Dimension, September-October 1972: 67-72.

Martell, George. "What Can I do Now?" in Close the 49th Parallel: The Americanization of Canada, edited by Ian Lumsden, 287-304. Toronto: University of Toronto Press, 1970.

The May Day Manifesto 1968. Edited by Raymond Williams. London: Verso Books, 2018. Reprint.

McNaughton, Andrew. "The NAWAPA Scheme and Canadian Sovereignty." Canadian Dimension, July-August 1966: 20-22.

McKay, Ian. "The Liberal Order Framework: A Prospectus for a Reconnaissance of Canadian History." Canadian Historical Review 81 (2000): 616-645.

----. Rebels, Reds, Radicals: Rethinking Canada's Left History. Toronto: Between the Lines, 2005.

Miliband, Ralph. The State in Capitalist Society. London: Quartet Books, 1973. Reprint.

-----. Marxism and Politics. Oxford and New York: Oxford University Press, 1977.

Milligan, Ian. Rebel Youth: 1960s Labour Unrest, Young Workers and New Leftists in English Canada. Vancouver: UBC Press, 2014.

Mills, Sean. The Empire Within: Postcolonial Thought and Political Activism in Sixties Montreal. Montreal: McGill-Queen's University Press, 2010.

-----. "Without Surrender: An Interview with Kari Levitt." Race and Class 52, no. 1 (October 2007): 49-56.

Moore, Steve, and Debbi Wells. Imperialism and the National Question in Canada. Toronto: S. Moore, 1975. 
Morton, Desmond. "The NDP Dilemma: Squash the Waffle or Give Way to Grits." Ottawa Citizen, November 4, 1971.

----. NDP: Social Democracy in Canada. Toronto: Samuel Stevens Hackkert, 1977, 2nd Ed.

----. NDP: The Dream of Power. Toronto: A. M. Hakkert, 1974, 1st Ed.

-----. The New Democrats, 1961-1986: The Politics of Change. Toronto: Copp Clark Pitman, 1986, 3rd Ed.

Mouat, Jeremy. "Thinking About Prairie Capitalism: Interviews with Larry Pratt and John Richards." Aurora Online. Issue 2005.

http://aurora.icaap.org/index.php/aurora/article/view/1/1

Muirhead, Bruce. "From Special Relationship to Third Option: Canada, The United States, and the Nixon Shock." American Review of Canadian Studies 34 (2004): 439-62.

Naylor, R. T. "The Rise and Fall of the Third Commercial Empire of the St. Lawrence." In Capitalism and the National Question in Canada, edited by Gary Teeple, 142. Toronto: University of Toronto Press, 1972.

Nelles, Viv, and Abraham Rotstein, editors. Nationalism or Local Control: Responses to George Woodcock. Toronto: New Press, 1973.

Newman, Michael. Ralph Miliband and the Politics of the New Left. London: Merlin Press, 2002.

Odell, John S. U.S. International Monetary Policy: Markets, Power, and Ideas as Sources of Change. Princeton, New Jersey: Princeton University Press, 1982.

Palaeologu, M. Athena, ed. The Sixties in Canada: A Turbulent and Creative Decade. Montreal: Black Rose Books, 2009.

Palmer, Bryan D. Canada's 1960s: The Ironies of Identity in a Rebellious Era. Toronto: University of Toronto Press, 2009.

-----. “The Socialist Dimension." In Canada Since 1960: A People’s History, edited by Cy Gonick, 462-99. Toronto: James Lorimer, 2016.

Panitch, Leo. “Editor's Preface." In The Canadian State: Political Economy and Political Power, edited by Leo Panitch, vii-xi. Toronto: University of Toronto Press, 1977. 
-----. "The Role and Nature of the Canadian State." In The Canadian State: Political Economy and Political Power, edited by Leo Panitch, 3-27. Toronto: University of Toronto Press, 1977.

----.. "Ralph Miliband, Socialist Intellectual: 1924-1994." Socialist Register (1995): 121.

Panitch, Leo, and Reginald Whitaker. "The New Waffle from Matthews to Marx." Canadian Dimension, April 1974: 51-56.

Parker, Ian. "Harold Innis, Karl Marx, and Canadian Political Economy." In Class, State, Ideology, and Change: Marxist Perspectives on Canada, edited by J. Paul Grayson. Toronto: Holt, Reinhart, and Winston, 1980.

Penner, Norman. The Canadian Left: A Critical Analysis. Toronto: Prentice-Hall, 1977.

Pratt, Larry. The Tar Sands: Syncrude and the Politics of Oil. Edmonton: Hurtig Publishers, 1976.

Prebisch, Raúl. The Economic Development of Latin America and Its Principal Problems. New York: United Nations, 1950.

Resnick, Philip. "Canadian Defence Policy and the American Empire." In Close the 49th Parallel Etc.: The Americanization of Canada, edited by Ian Lumsden, 93116. Toronto: University of Toronto Press, 1970.

----. The Land of Cain: Class and Nationalism in English Canada, 1945-65. Vancouver: New Star Books, 1977.

-----. The Masks of Proteus: Canadian Images of the State. Montreal: McGill-Queen's University Press, 1990.

Richards, John, and Larry Pratt. Prairie Capitalism: Power and Influence in the New West. Toronto: McClelland and Stewart, 1979.

Rohmer, Richard. The Arctic Imperative: An Overview of the Energy Crisis. Toronto: McClelland and Stewart, 1975.

----. Independence: The Canadian Challenge. Toronto: The Committee for an Independent Canada, 1972.

Rotstein, Abraham. "Binding Prometheus." In Close the 49th Parallel Etc.: The Americanization of Canada, edited by Ian Lumsden. Toronto: University of Toronto Press, 1970. 
----. "Canada: The New Nationalism." Foreign Affairs 55, no. 1 (October 1976): 97118.

-----. Precarious Homestead: Essays on Economics, Technology, and Nationalism. Toronto: New Press, 1973.

-----. "The Staple Theory Redux: On the Origin of Species." In The Staple Theory @ 50: Reflections on the Lasting Significance of Mel Watkins': "A Staple Theory of Economic Growth," edited by Jim Stanford, 11-15. Ottawa: Canadian Centre for Policy Alternatives, 2013.

Rotstein, Abraham, and Gunnar Adler-Karlsson. Reclaiming the Canadian Economy: A Swedish Approach Through Functional Socialism. Toronto: House of Anansi Press, 1970.

Rotstein, Abraham, and Gary Lax. Getting it Back: A Program for Canadian Independence. Toronto: Clarke, Irwin, 1974.

Rugman, Alan M. Multinationals in Canada: Theory, Performance, and Economic Impact. Boston: M. Nijhoff Publications, 1980.

Russell, J. C. "Earth, Fire and Water: Towards a Policy for Energy Resources." In Getting it Back: A Program for Canadian Independence, edited by Gary Lax and Abraham Rotstein, 99-113. Toronto: Clark, Irwin, 1973.

Russell, Peter, ed. Nationalism in Canada. Toronto: McGraw-Hill, 1966.

Safarian, A. E. Foreign Ownership of Canadian Industry. Toronto: McGraw-Hill Canada, 1972.

Sangster, Joan. "Radical Ruptures: Feminism, Labor and the Left in the Long Sixties in Canada." American Review of Canadian Studies 40, no. 1 (2010), 1-21.

Sargent, Daniel J. A Superpower Transformed: The Remaking of American Foreign Relations in the 1970s. New York: Oxford University Press, 2015.

Schmidt, Ray. “Canadian Political Economy: A Critique." Studies in Political Economy 6 (1981): 65-92.

Smart, John. "The Waffle's Impact on the New Democratic Party," Studies in Political Economy 32 (1990): 177-86.

Smart, Patricia. "The Waffle and Quebec." Studies in Political Economy 32 (1990): 195-201. 
Smith, Allan. "Doing the Continental: Conceptualizations of the Canadian-American Relationship in the Long Twentieth Century." Canadian-American Public Policy 44 (2000): 2-70.

Smith, Burton M. "The United States in Recent Canadian Nationalism." World Affairs 140, no. 3 (Winter 1978): 195-205.

Smith, Cameron. Unfinished Journey: The Lewis Family. Toronto: Summerhill Press, 1989.

Smith, Miriam. "The Canadian Labour Congress: From Continentalism to Economic Nationalism." Studies in Political Economy 38 (1992): 35-60.

Smith, Murray. "The National Question: Political Economy and the Canadian Working Class: Marxism or Nationalism Reformism?" Labour/Le Travail 46 (2000): 343-68.

"Spring Cleaning: How Stephen Lewis Gave up Wellington Boots, the Waffle, the NDY, and Grew Wiser in his Years." Last Post, April-May 1971.

Squires, Jessica. Building Sanctuary: The Movement to Support Vietnam War Resisters in Canada, 1965-73. Vancouver: UBC Press, 2013.

Stephens, Cody. "The Accidental Marxist: Andre Gunder Frank and the "NeoMarxist" Theory of Underdevelopment, 1958-1967." Modern Intellectual History 15, no. 2, 411-442.

Stewart, Walter. "On the Left, Mel Watkins. In the Middle, Joe Greene. The Heavyweight Contest to Choose Captain Canada of 1971." Maclean's, 1 November 1970: 31-35.

----. "Water: The Sellout that Could Spell the End of Canada." Maclean's, 1 March 1970. 42-45.

Stuart, Reginald. "Continentalism Revisited: Recent Narratives on the History of Canadian-American Relations." Diplomatic History 18 (1994): 405-14.

Sweezy, Paul. The Theory of Capitalist Development. London: D. Donson, 1949.

Sykes, Philip. Sellout: The Giveaway of Canada's Energy Resources. Edmonton: Hurtig Publishers, 1973.

Taylor, Charles. Radical Tories: The Conservative Tradition in Canada. Toronto: House of Anansi Press, 1982. 
Teeple, Gary, ed. Capitalism and the National Question in Canada. Toronto: University of Toronto Press, 1972.

Thompson, John Herd, and Stephen J. Randall. Canada and the United States: Ambivalent Allies. Montreal: McGill-Queen's University Press, 1994.

Thordarson, Bruce. Trudeau and Foreign Policy: A Study in Decision-Making. Toronto: Oxford University Press, 1972.

Traves, Tom. The State and Enterprise: Canadian Manufacturers and the Federal Government, 1917-1931. Toronto: University of Toronto Press, 1979.

“U.S. Invites Canada to Pool oil, Gas, Hydro.” Toronto Star, 5 December 1969.

Valasco, Andres. “Dependency Theory." Foreign Policy, November 1, 2002.

Wallerstein, Immanuel. The Capitalist World Economy. Cambridge: Cambridge University Press, 1979.

-----."Semi-Peripheral Countries and the Contemporary World Crisis in the Capitalist World Economy." In Essays by Immanuel Wallerstein, ed. Immanuel Wallerstein, 95-118. Cambridge: Cambridge University Press, 1979.

Warnock, John. "Canada and the Alliance System," Canadian Dimension, March-April 1966: 36-40.

-----. "The Mackenzie Valley Pipeline: A \$5 Billion Disaster." Canadian Dimension, October 1972: 35-40.

Watkins, Mel. "Attacking America's International Corporations Multi-Nationally." Canadian Dimension, October-November 1970: 7-9.

-----. “Learning to Move Left." This Magazine is About Schools, Spring 1972: 68-92.

-----. "Contradictions and Alternatives in Canada's Future." In (Canada) Ltd.: The Political Economy of Dependency, edited by Robert Laxer, 250-269. Toronto: McClelland and Stewart, 1973.

-----. "Resources and Underdevelopment." In (Canada) Ltd.: The Political Economy of Dependency, edited by Robert Laxer. 107-26. Toronto: McClelland and Stewart, 1973.

----. "From Development to Underdevelopment." In Dene Nation: The Colony Within, edited by Mel Watkins, 84-99. Toronto: University of Toronto Press, 1977. 
-----. "The Staple Theory Revisited." Journal of Canadian Studies 12, no. 5 (Winter 1977): 83-94.

-----. “The US-Canada Free Trade Agreement." Monthly Review (September 1988): $34-42$.

-----. "The Waffle and the National Question." Studies in Political Economy 32 (1990): 173-76.

“We're Not for Sale." Toronto Star, 6 December 1970.

Whitaker, Reginald. "Images of the State in Canada." In The Canadian State: Political Economy and Political Power, edited by Leo Panitch, 28-68. Toronto: University of Toronto Press, 1977.

----.. "The 20th Anniversary of the Waffle - Introduction." Studies in Political Economy 32 (1990): 167-72.

Whitehorn, Alan. Canadian Socialism: Essays on the CCF-NDP. Toronto: Oxford University Press, 1992.

Wiseman, Nelson, and Benjamin Isitt. "Social Democracy in Twentieth Century Canada: An Interpretive Framework." Canadian Journal of Political Science 40 (2007): 567-89.

Woodcock, George. "A Plea for the Anti-Nation." Canadian Forum, April 1972, 16-19.

Zaritsky, John. "The Jubilant Waffle Sees Victory in NDP Convention Defeat." Globe and Mail, April 26, 1971.

\section{Theses}

Blocker, David. "'To Waffle to the Left:' The Waffle, the New Democratic Party, and Canada's New Left during the Long Sixties." PhD Dissertation, Western University, 2019.

Borch, Peter. "The Rise and Decline of the Saskatchewan Waffle, 1966-1973." M. A. Thesis, University of Regina, 2005.

Webber, Patrick. "For a Socialist New Brunswick: The New Brunswick Waffle, 19671972." M. A. Thesis, University of New Brunswick, 2008. 